\title{
EFEITO DO ANELAMENTO E DE DOSES DE ÁCIDO GIBERÉLICO NA FRUTIFICAÇÃO DAS UVAS 'NIAGARA ROSADA' E 'VÊNUS' NAS REGIÕES NOROESTE E DA ALTA PAULISTA DO ESTADO DE SÃO PAULO
}

\author{
STELLA CONSORTE CATO
}

Dissertação apresentada à Escola Superior de Agricultura "Luiz de Queiroz", Universidade de São

Paulo, para obtenção do título de Mestre em Agronomia, Área de Concentração: Fitotecnia.

\author{
P I R A C I C A B A \\ Estado de São Paulo - Brasil
}

Abril - 2002 


\title{
EFEITO DO ANELAMENTO E DE DOSES DE ÁCIDO GIBERÉLICO NA FRUTIFICAÇÃO DAS UVAS 'NIAGARA ROSADA' E 'VÊNUS' NAS REGIÕES NOROESTE E DA ALTA PAULISTA DO ESTADO DE SÃO PAULO
}

\section{STELLA CONSORTE CATO}

Engenheiro Agrônomo

Orientador: Dr. MAURILO MONTEIRO TERRA

\author{
Dissertação apresentada à Escola Superior de \\ Agricultura "Luiz de Queiroz", Universidade de São \\ Paulo, para obtenção do título de Mestre em \\ Agronomia, Área de Concentração: Fitotecnia.
}

PI R A C I C A B A

Estado de São Paulo - Brasil

Abril - 2002 


\section{Dados Internacionais de Catalogação na Publicação (CIP) DIVISÃO DE BIBLIOTECA E DOCUMENTAÇÃO - ESALQ/USP}

\section{Cato, Stella Consorte}

Efeito do anela mento e de doses se ácido giberélico na frutific ação das uvas Niagara Rosada 'e Vênus' na regiões noroeste e da alta paulista do Estado de São Paulo / Stella Consorte Cato. - - Piracicaba, 2002.

$112 \mathrm{p}$.

Dissertação (mestrado) - - Escola Superior de Agricultura Luiz de Queiroz, 2002. Bibliogra fia.

1. Ácido giberélic o 2. Praticas cultura is (Fitotec nia) 3. Regula dores de c resc imento vegetal I. Titulo

CDD 634.8

"Permitida a cópia total ou parcial deste documento, desde que citada a fonte - $\mathrm{O}$ autor" 


\begin{abstract}
À minha mãe, Maria, e ao meu
pai, Zauri (in memorian), pelos

ensinamentos de vida e constante apoio em meus estudos. Às

minhas irmãs, Jussara e Mariana,

pelo incentivo, e ao Marcos pela

compreensão
\end{abstract}

DEDICO 


\section{AGRADECIMENTOS}

Ao Dr. Maurilo Monteiro Terra, pela orientação, amparo e incentivo durante a execução deste trabalho.

Ao Dr. Erasmo José Paioli Pires e ao colega Renato Vasconcelos Botelho, pelo apoio, amizade e colaboração.

À Pesquisadora Científica Cássia Regina Limonta Carvalho pela colaboração e orientação nas análises químicas.

Aos professores, funcionários e alunos da Escola Superior de Agricultura "Luiz de Queiroz", principalmente do Departamento de Produção Vegetal, pelos ensinamentos transmitidos durante as disciplinas que tomaram parte de minha formação profissional, apoio e coleguismo.

À Prof ${ }^{a}$. Dr ${ }^{\mathrm{a}}$. Sônia Maria Stefano Piedade do Departamento de Ciências Exatas da Escola Superior de Agricultura "Luiz de Queiroz", e à Pesquisadora Científica Ivani Pozar Otsuk, do Instituto de Zootecnia, pelo apoio para a realização das análises estatísticas.

Ao Instituto Agronômico de Campinas (IAC) pela cessão de funcionários, equipamentos e instalações para a realização deste trabalho.

À Fundação de Amparo à Pesquisa do Estado de São Paulo (FAPESP) pela concessão da bolsa de estudos, que possibilitou-me a realização do curso de PósGraduação.

Aos funcionários do Instituto Agronômico de Campinas, Valdeir Biudes Hermoso e Maria das Graças dos Santos Lima, pelo apoio para a realização dos trabalhos de campo e das medidas de laboratório. 
Aos viticultores Adalberte Stivari e Cícero Lourenço de Paula e ao Centro Nacional de Pesquisa de Uva e Vinho da EMBRAPA, Unidade Experimental de Jales, pela disponibilização de seus vinhedos para a condução dos experimentos.

Às Bibliotecárias Eliana Maria Garcia e Silvia Maria Zinsly da Biblioteca Central da Escola Superior de Agricultura "Luiz de Queiroz", pelas sugestões e apoio durante a revisão deste trabalho. 


\section{SUMÁRIO}

Página

RESUMO

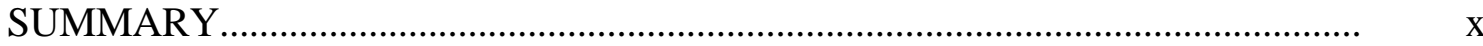

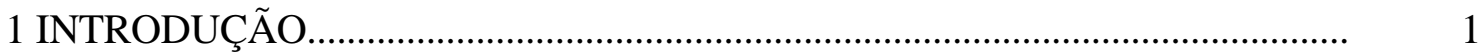

2 REVISÃO DE LITERATURA..................................................................

2.1 Características das cultivares em estudo............................................................. 3

2.2 Conceito, modificações fisiológicas e efeito do anelamento em cultivares de uva de mesa....................................................................................

2.3 Conceito, modificações citológicas e fisiológicas e efeito da aplicação de ácido giberélico em cultivares de uva de mesa............................................... 6

2.4 Efeito de práticas culturais associadas à aplicação de ácido giberélico em cultivares de uva de mesa...................................................................... 8

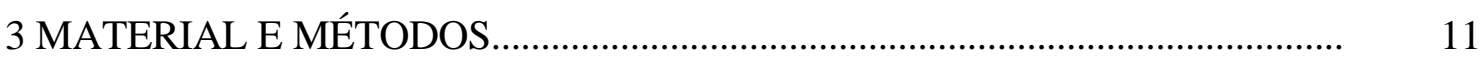

3.1 Experimentos com a cultivar Niagara Rosada..................................................... 11

3.1.1 Experimento com a cultivar Niagara Rosada realizado no primeiro ciclo vegetativo de 1999...........................................................................................

3.1.2 Experimento com a cultivar Niagara Rosada realizado no segundo ciclo vegetativo de 1999 .......................................................................................... 13

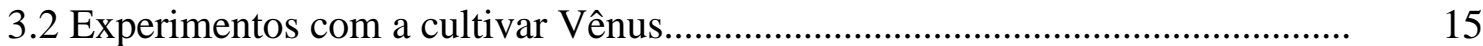

3.2.1 Experimento com a cultivar Vênus realizado no ciclo vegetativo de 1999. 
3.2.2 Experimento com a cultivar Vênus realizado no ciclo vegetativo de

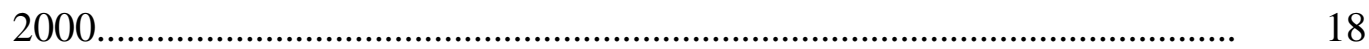

4 RESULTADOS E DISCUSS ÃO.......................................................................... 20

4.1 Experimentos com a cultivar Niagara Rosada..................................................... 20

4.1.1 'Niagara Rosada' - Primeiro ciclo vegetativo de 1999...................................... 20

4.1.2 'Niagara Rosada' - Segundo ciclo vegetativo de 1999..................................... 39

4.2 Experimentos com a cultivar Vênus..............................................................

4.2.1 Cultivar Vênus - Ciclo vegetativo de 1999................................................. 59

4.2.2 Cultivar Vênus - Ciclo vegetativo de 2000..................................................... 76

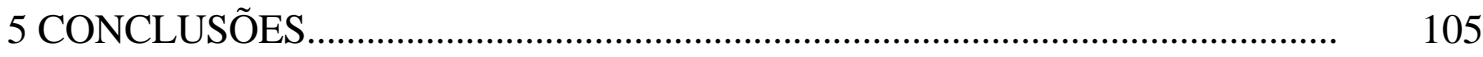

REFERÊNCIAS BIBLIOGRÁFICAS..................................................................... 108 


\title{
EFEITO DO ANELAMENTO E DE DOSES DE ÁCIDO GIBERÉLICO NA FRUTIFICAÇÃO DAS UVAS 'NIAGARA ROSADA' E 'VÊNUS' NAS REGIÕES NOROESTE E DA ALTA PAULISTA DO ESTADO DE SÃO PAULO
}

\author{
Autora: STELLA CONSORTE CATO \\ Orientador: Dr. MAURILO MONTEIRO TERRA
}

\section{RESUMO}

O presente trabalho foi desenvolvido com o objetivo de avaliar o efeito do ácido giberélico em doses crescentes, isoladamente ou em conjunto com o anelamento de ramos e/ou com o desponte de cachos sobre as características dos cachos, bagos e engaços das cultivares de uvas de mesa Niagara Rosada e Vênus. Foram realizados dois experimentos para cada cultivar nas regiões noroeste e da alta paulista do Estado de São Paulo, e os delineamentos estatísticos utilizados foram em blocos ao acaso, com cinco repetições sendo quatorze e dezoito tratamentos para 'Niagara Rosada' e vinte e oito tratamentos para cada experimento com 'Vênus'. Para todos os experimentos, o ácido giberélico nas doses de 0; $10 ; 22,5 ; 35 ; 47,5 ; 60$ e 72,5ppm, foi aplicado quinze dias após o pleno florescimento, através da imersão total dos cachos, com exceção de um experimento com 'Niagara Rosada', no qual foi acrescido mais duas doses de 85 e 97,5ppm. O anelamento nos ramos produtivos foi realizado também nesta mesma época. No primeiro experimento com 'Niagara Rosada' detectou-se que não houve influência do anelamento de ramos sobre a massa e o tamanho médio dos bagos. Também, a dose de 35ppm de ácido giberélico sendo aplicada isoladamente originou incrementos na massa e tamanho médio dos cachos e bagos. Esta mesma dose quando aplicada conjuntamente com o anelamento de 
ramos proporcionou incrementos no teor de sólidos solúveis totais do mosto. No segundo experimento com 'Niagara Rosada', maiores incrementos no tamanho e massa dos bagos, assim como no diâmetro médio dos pedicelos foram obtidos com a aplicação de 60ppm de ácido giberélico conjuntamente com o anelamento de ramos. Já, os maiores incrementos na massa e na largura dos cachos e no número médio de bagos por cacho foram obtidos com a dose de 35ppm aplicada conjuntamente com a prática do anelamento. Já, com a cultivar Vênus no ciclo vegetativo de 1999 verificou-se que quanto maior a dose de ácido giberélico, maior foi o comprimento, a largura e a massa dos bagos. Também, o anelamento realizado isoladamente ou conjuntamente com o desponte de cachos proporcionou o aumento destas mesmas características. No experimento com a cultivar 'Vênus' no ciclo vegetativo de 2000 notou-se que quanto maior a dose de ácido giberélico, maior foi o comprimento e a largura dos cachos e engaços. A dose de 35ppm de ácido giberélico, aplicada conjuntamente com o anelamento de ramos isoladamente ou com o desponte de cachos, proporcionou as maiores massas de cachos e engaços e o maior número médio de bagos por cacho. Maiores bagos foram obtidos com a aplicação de 60ppm de ácido giberélico realizada conjuntamente com o anelamento de ramos isoladamente ou em conjunto com o desponte de cachos. A maior massa de bagos foi obtida com a aplicação isolada de 47,5ppm de ácido giberélico. Também, obteve-se menores teores de sólidos solúveis totais com doses maiores do regulador vegetal aplicadas conjuntamente com a técnica de incisão anelar. 


\title{
EFFECT OF GIRDLING AND GIBBERELLIC ACID ON THE FRUIT SET OF 'NIAGARA ROSADA' AND 'VENUS' GRAPEVINES GROWING IN THE NORTHWEST AREA OF SÃO PAULO STATE
}

\author{
Author: STELLA CONSORTE CATO \\ Adviser: Dr. MAURILO MONTEIRO TERRA
}

\section{SUMMARY}

The present work was developed to evaluate the effect on the cluster, berries and raquis characteristics of Niagara Rosada and Venus table grapes of increasing doses of gibberellic acid associated or not with branch girdling and/or cluster blunt. Two experiments, for each cultivar, were accomplished in the northwest area of São Paulo State, Brazil, in a randomized block design, with five replications, being fourteen and eighteen treatments for 'Niagara Rosada' and twenty-eight treatments for 'Venus'. The gibberellic acid in the doses of $0 ; 10 ; 22,5 ; 35 ; 47,5 ; 60$ and 72,5ppm, was applied, through the total immersion of the clusters, fifteen days after the full flowering, except for the second experiment with 'Niagara Rosada', in which was added up two more doses of 85 and 97,5ppm. The girdling in the productive branches was also accomplished in this same time. In the first experiment with 'Niagara Rosada' no effect of girdling was detected on the berry mass and size. Also, gibberellic acid (35ppm) alone increased cluster and berry mass and size. This same dose when associated with girdling provided increase in the soluble solids. In the second experiment with 'Niagara Rosada', larger increments on berry size and mass, as well as, pedicels diameter were obtained with gibberellic acid (60ppm) associated with branch girdling. The largest increments on cluster mass and width and on the berry number per cluster, were 
obtained applying gibberellic acid (35ppm) associated with girdling. In the first experiment with 'Venus' seedless table grape in 1999 it was detected that the higher the concentrations of gibberellic acid, the larger were berry length, width and the mass. Also, girdling associated or not with cluster blunt increased these same characteristics. In the second experiment with 'Venus' cultivar it was noticed that the higher the concentrations of gibberellic acid, the larger were cluster and raquis length and width. Gibberellic acid (35ppm) associated with girdling only or with cluster blunt provided the largest increase on cluster and raquis masses and the largest berry number per cluster. Larger berries were obtained with gibberellic acid (60ppm) associated with girdling only or with cluster blunt. The largest berry mass was obtained with gibberellic acid $(47,5 \mathrm{ppm})$. Also, it was detected a decrease in soluble solids with higher concentrations of the vegetable regulator associated with girdling. 


\section{INTRODUÇÃO}

Analisando dados fornecidos pelo Instituto Brasileiro de Geografia e Estatística (IBGE) (2001) observa-se que a produção de uvas no Brasil tem aumentado nos últimos anos, com uma produção até outubro de 2001 de 1.022.022 toneladas, sendo que as principais regiões produtoras são: o Sul, com uma produção de 613.468 toneladas, destinadas, principalmente, à vinificação; o Sudeste, com 226.600 toneladas de uvas de mesa, sendo que deste montante, 213.329 toneladas foram produzidas no Estado de São Paulo; e o Nordeste que encontra-se em franca expansão, produzindo 181.954 toneladas de uvas de mesa.

Hoje, no mercado de frutas em geral, há maior potencial de crescimento para produtos de qualidade superior e, no caso da uva de mesa, prioridade tem sido dada ao cultivo de variedades sem sementes, visando conquistar cada vez mais o mercado externo. Portanto, há a necessidade de se adaptar o cultivo dessas variedades às condições de clima brasileiro. Dentre as variedades cultivadas no Estado de São Paulo, a cultivar com sementes Niagara Rosada representa ainda um grande volume de uvas comercializadas na CEAGESP-SP. Outras variedades como a Itália e Rubi são de grande importância para a viticultura paulista, assim como as uvas sem sementes, que têm despertado o interesse de muitos produtores no Estado de São Paulo e vêm conquistando muitos consumidores, principalmente, no mercado internacional.

Trabalhando com a cultivar de uvas apirenas de mesa Vênus, produtores da região noroeste do Estado de São Paulo têm observado que os cachos apresentam tamanho e massa reduzida para esta variedade, além de apresentarem a ponta afilada, característica que deprecia o produto e dificulta o acondicionamento dos cachos em embalagens para a comercialização. Já, na região da alta paulista do Estado de São Paulo há o problema de a cultivar Niagara Rosada apresentar massa dos cachos e o tamanho e 
massa dos bagos menores quando comparados aos produzidos na região tradicional de Jundiaí; isto pode ser devido a um encurtamento no ciclo da videira quando cultivada em regiões de climas mais quentes.

Algumas práticas culturais como anelamento de ramos, desbaste de cachos e aplicação de reguladores vegetais, visam proporcionar melhorias no produto colhido, mas analisando-se a bibliografia disponível observa-se certa variabilidade nos resultados obtidos em função das cultivares, do clima da região em estudo, da época em que os tratamentos são realizados, da dose do regulador com relação ao estádio fenológico da cultura e da combinação desses reguladores com práticas comumente realizadas na cultura da videira.

Isto justifica a necessidade de se obter a concentração adequada do regulador vegetal combinada ou não com determinadas práticas culturais, em função da cultivar e das condições climáticas de cada região.

Com o objetivo de propor soluções para os problemas enfrentados pelos produtores das regiões noroeste e da alta paulista do Estado de São Paulo, este trabalho teve como objetivo avaliar o efeito do ácido giberélico em doses crescentes, isoladamente ou em conjunto com a incisão anelar e/ou com o desponte de cachos, sobre características quantitativas e qualitativas das cultivares de uvas de mesa Niagara Rosada e Vênus, desenvolvidas nestas regiões. 


\section{REVISÃO DE LITERATURA}

\subsection{Características das cultivares em estudo}

A cultivar Niagara Rosada é uma uva rústica de mesa, surgida de uma mutação somática natural na Niagara Branca. A planta é de vigor médio, tolerante às doenças e pragas e produtiva, por esta razão é uma das cultivares mais plantadas no Estado de São Paulo. Os cachos são de tamanho médio, cônicos e compactos, com baixa resistência ao transporte e ao armazenamento. Bagos de coloração rosada, tamanho médio, de forma ovalada, sucosa e com muita pruína; sabor doce foxado, muito apreciado pelo paladar brasileiro (Pommer et al.,1997).

A cultivar Vênus foi obtida no programa de melhoramento de Arkansas, E.U.A., é descendente do cruzamento entre Alden e NY 46.000. As plantas são vigorosas e produtivas (17 a 20 t/ha). Os cachos são cilíndricos, médios a grandes (200 a 400 g) e medianamente compactos; os bagos, para uvas sem sementes e sem aplicação de ácido giberélico, atingem massa razoável (3g); são arredondados e de cor preto-azulada, devido à pruína. $\mathrm{O}$ sabor tende ao foxado. Apresenta ótimo potencial. Na região noroeste paulista já existem pequenos lotes comerciais, porém, talvez devido ao clima da região, por apresentar temperaturas um tanto elevadas, o ciclo da cultura é menor, apresentando desenvolvimento mais acelerado e, consequentemente cachos com tamanho de bagos reduzidos (Pommer et al.,1997).

\subsection{Conceito, modificações fisiológicas e efeito do anelamento em cultivares de uva de mesa}

O anelamento ou incisão anelar consiste na retirada de um anel da casca do tronco ou de ramos lenhosos, de cerca de 3 a 6 mm de largura (Terra et al., 1998). 
Mason e Makell, citados por Taiz \& Zeiger (1998), observaram que a remoção de um anel de casca de uma árvore, tratamento este chamado de anelamento, bloqueava o transporte de açúcares no local onde a casca havia sido removida, porém não se observava efeito imediato na transpiração, uma vez que a água se move através do xilema. Os mesmos autores observaram ainda que os açúcares se acumulam acima da região anelada, na parte área portanto, e se esgotam abaixo desta região. Eventualmente, a casca abaixo do anel necrosava, enquanto observava-se um inchaço na região acima do anel, e a casca permanecia saudável. O efeito fisiológico primário dessa prática é o acúmulo de carboidratos nas partes acima da incisão. Roper \& Williams (1989) observaram que a concentração foliar de carboidratos era maior em videiras que sofreram incisão anelar.

Em videiras, o anelamento foi realizado pela primeira vez em 1745 e verificou-se com a adoção desta técnica o aumento da massa dos bagos e o adiantamento da maturação (Husmann, 1898 citado por Zabadal, 1992). Segundo Peruzzo (1994) o anelamento de ramos é uma prática cultural muito usada para uva de mesa em outros países, pois além de antecipar a maturação, também pode promover a uniformização do tamanho dos frutos, melhorando a aparência final dos cachos, porém pouco se sabe a respeito das respostas ao anelamento das videiras cultivadas no Brasil. De acordo com Gonzalo et al. (1984), os resultados obtidos com a prática do anelamento dependem da cultivar e do momento em que este é realizado, sendo que após a frutificação há um efeito positivo no tamanho dos bagos.

Terra et al. (1998) descreveram os seguintes objetivos que podem ser alcançados em função do estádio em que é realizada a incisão anelar:

- Aumento do número de bagos quando o anelamento é feito durante o florescimento ou imediatamente após.

- Aumento do tamanho dos bagos efetuando-se a incisão duas ou três semanas após o pleno florescimento.

- Antecipação na maturação quando praticado na época da "viragem" ("veraison"), que corresponde ao início do amolecimento dos bagos nas variedades de uvas brancas, ou ao início da formação de cor nos bagos de variedades rosadas ou pretas. 
O efeito da incisão anelar na maturação de uvas com sementes foi estudado por Pommer et al. (1991), em vinhedos comerciais das cultivares Traviú e Niagara Rosada, no município de Jundiaí-SP. Para Niagara Rosada foram observados efeitos positivos nas plantas que sofreram anelamento, com relação às características qualitativas, pois o teor de sólidos solúveis foi significativamente maior nos frutos de plantas aneladas e a porcentagem de bagos verdes presentes no cacho, no momento da colheita, foi nove vezes menor que em plantas não aneladas. Para Traviú não se observou qualquer efeito do anelamento para as características avaliadas devido, provavelmente, ao fato de o mesmo ter sido efetuado após o "veraison".

Antonacci (1993) trabalhando com a cultivar Itália observou que o anelamento após a frutificação aumentou a massa dos bagos e o teor de sólidos solúveis.

Peruzzo (1994) testou o anelamento de ramos durante o pleno florescimento e no início da maturação em duas cultivares de uva: Cardinal e Ruby Seedless. Nas duas cultivares, a prática do anelamento ocasionou uma antecipação da maturação de doze dias nos ramos anelados durante o florescimento e de sete dias para os ramos anelados no início da maturação. A cultivar Cardinal apresentou aumento de massa média dos cachos de $21 \%$ e $9 \%$ nos ramos anelados durante o florescimento e no início da maturação, respectivamente. No caso da cultivar Ruby Seedless os ganhos de massa dos cachos foram de $29 \%$ e $12 \%$ quando a incisão foi realizada no florescimento e no início da maturação, respectivamente.

Carreño et al. (1998) estudaram o efeito do anelamento sobre o desenvolvimento da cultivar Itália: depois da frutificação; no início do amadurecimento ("veraison") e o duplo anelamento ( na frutificação e no "veraison"). $\mathrm{O}$ anelamento após a frutificação aumentou significativamente a massa de bagos e a produção. Quando o mesmo foi realizado no início do amadurecimento, houve um aumento significativo no teor de sólidos solúveis, no índice de maturação e na cor dos bagos. Observourse, também, uma diminuição na acidez e uma antecipação de cinco dias, no amadurecimento. Já, o duplo anelamento aumentou significativamente a massa dos bagos e a produção, e produziu os melhores resultados com relação a sólidos solúveis, índice de maturação, cor de bagos e antecipação da colheita. 


\subsection{Conceito, modificações citológicas e fisiológicas e efeito da aplicação de ácido giberélico em cultivares de uva de mesa}

As giberelinas são um grupo de compostos relacionados, sendo conhecidos atualmente mais de cento e dez, definidos de acordo com as suas estruturas químicas, alguns dos quais são encontrados apenas no fungo Gibberella fujikuroi. Embora as giberelinas tenham se tornado conhecidas pelos cientistas americanos e britânicos na década de 50, elas já haviam sido descobertas muito antes pelos cientistas japoneses, quando rizicultores asiáticos tomaram o conhecimento de uma doença que provocava o estiolamento de plantas de arroz e estas não produziam sementes. Os fitopatologistas descobriram que tal doença era induzida por uma substância química secretada pelo fungo Gibberella fujikuroi, que deu origem ao nome desse grupo de compostos (Taiz \& Zeiger, 1998).

As giberelinas têm diversas aplicações comerciais, sendo que um dos maiores usos das giberelinas é o de aumentar o comprimento do pedicelo de uvas sem sementes. Devido ao comprimento muito reduzido dos pedicelos de cada um dos bagos, os cachos de uvas sem sementes são muito compactos e o crescimento dos bagos é restrito. Promovendo elongação nos pedicelos, as giberelinas permitem que os bagos tenham maior espaço para se desenvolver (Taiz \& Zeiger, 1998).

A giberelina aumenta tanto a expansão como a divisão celular. A provável hipótese com relação ao mecanismo através do qual as giberelinas estimulam a expansão celular, é a hidrólise do amido. Elas podem gerar $\alpha$-amilase que hidrolisa o amido, incrementando a produção de açúcares e elevando a pressão osmótica do suco celular, fazendo com que a água entre nas células e estas sejam expandidas (Pires, 1998).

A giberelina ou ácido giberélico é o regulador vegetal de uso mais antigo em viticultura (Sousa,1996). Segundo Pereira \& Oliveira (1976), as aplicações são feitas desde o aparecimento da inflorescência até o início da maturação e visam aumentar a produção, através do aumento da massa dos cachos; melhorar a qualidade da uva, aumentando o tamanho dos cachos e dos bagos e obter cachos medianamente soltos, dispensando a operação de desbaste e facilitando o controle de doenças. Além de proporcionar efeitos benéficos nas características morfológicas dos cachos, o ácido 
giberélico pode acarretar no engrossamento dos pedicelos e engaços, obtenção de frutos sem sementes e diminuição do ciclo da videira . Esses mesmos autores, trabalhando com a cultivar Itália, constataram que a imersão de inflorescências em 5ppm de ácido giberélico, antes do florescimento, aumentou o número de bagos retido nos cachos, enquanto que a imersão em 5 ou 10ppm depois do florescimento aumentou a massa dos cachos e dos bagos (Pereira \& Oliveira, 1977).

Em cultivares de uvas de mesa apirenas falta giberelina endógena necessária para maximizar o crescimento do fruto, consequentemente em cultivos comerciais é comum a aplicação de ácido giberélico, porém como já citado anteriormente seus efeitos são variáveis em função das condições climáticas e da variedade, necessitando a determinação da concentração adequada e as melhores épocas de aplicação.

Videiras da cultivar Flame Seedless pulverizadas com ácido giberélico a 5, 10 ou 20ppm durante o pleno florescimento e novamente na frutificação (logo após a queda natural de frutos), não apresentaram aumento significativo na massa de cachos, na largura, comprimento e massa de bagos, e no teor de sólidos solúveis em resposta aos tratamentos. As maiores massas de cachos e bagos foram obtidas com a aplicação de 10 e 20ppm de ácido giberélico (GA3), respectivamente. A maior largura e comprimento de bagos e teor de sólidos solúveis foi obtida com a aplicação de 20ppm do regulador de crescimento. O tratamento com GA3 também reduziu o número de bagos/cachos e bagos/cm de ráquis (Altaf et al., 1989).

No Arkansas, Clark et al.(1993) obtiveram aumento na massa de bagos da cultivar apirena Vênus com aplicações de 150 ou 300ppm de ácido giberélico em pré e em pós-florescimento. O mesmo não foi observado com a cultivar Saturn, cujos bagos não apresentaram ganho de massa.

No Chile, na cultivar Sultanina, é comum a realização de duas aplicações de ácido giberélico na dose de 40ppm cada, sendo uma quando os bagos apresentam $4 \mathrm{~mm}$ de diâmetro e outra uma semana mais tarde (Retamales et al., 1995).

Lee et al. (1997) puderam verificar o efeito da aplicação de giberelina na frutificação, crescimento e alongamento do cacho de setenta e sete cultivares de una. Uma única aplicação de giberelina realizada após o pleno florescimento (particularmente 
10 dias após o florescimento) teve maior influência no desenvolvimento do fruto.

Em experimentos realizados no Chile com videiras da cultivar Thompson Seedless, tratadas com ácido giberélico nas concentrações de 30ppm, aplicado no florescimento, 110 ou 250ppm, divididos em duas aplicações, no florescimento e após a frutificação, apresentaram maior queda de frutos e menor flexibilidade do pedicelo com doses maiores de ácido giberélico (Retamales et al., 1993).

Trabalhando com a cultivar Niagara Rosada, no município de Jundiaí, Castro (1975) constatou que a aplicação de ácido giberélico na concentração de 100ppm em pós-florescimento, provocou aumento na massa do cacho, número e massa de bagos, além de alongamento da ráquis.

Pereira et al.(1979) realizaram ensaios com a cultivar Niagara Rosada, cujos cachos foram imersos em soluções de ácido giberélico nas concentrações de 0 a 400ppm, 12 dias antes e/ou 7 dias após o florescimento. Os autores observaram que o tratamento duplo com 100ppm de ácido giberélico, antes e após o florescimento, gerou aumento significativo na massa da ráquis e no comprimento e largura do cacho. $\mathrm{O}$ número de bagos por cacho, massa de bagos e número de sementes não foram afetados pelos tratamentos.

Na Líbia, El-Hodairi \& Ibrahim (1995) trabalhando com a cultivar Sultanina avaliaram o efeito de duas aplicações de ácido giberélico nas doses de 0, 20, 30, 40 e $50 \mathrm{ppm}$, sendo antes do florescimento ou após a frutificação. Os resultados indicaram um efeito hormonal claro sobre o tamanho do fruto quando o ácido giberélico foi aplicado após a frutificação, principalmente na dose de $50 \mathrm{ppm}$. O comprimento dos cachos não foi afetado, contudo houve efeito sobre o comprimento dos bagos, sendo maior com a aplicação de 50ppm antes do florescimento ou após a frutificação.

\subsection{Efeito de práticas culturais associadas à aplicação de ácido giberélico em cultivares de uva de mesa}

$\mathrm{O}$ uso conjunto de práticas que melhoram o aspecto comercial dos cachos vem sendo estudado há tempos.

Antonacci (1992) observou que as cultivares Blush Seedless, Centennial 
Seedless, Passiga, Perlon, Rutilia, Argentina e Sugraone responderam bem ao anelamento e ao desbaste de cachos. Porém, a resposta em termos de qualidade do fruto à aplicação de 50ppm de ácido giberélico foi variável entre as cultivares, sendo que foram afetadas positivamente as cultivares Centennial Seedless, Passiga e Perlon. Já, Antonacci \& Colleta (1996) pulverizaram a cultivar Regina no início do desenvolvimento dos frutos com 2 ou $4 \mathrm{mg}$ de ácido giberélico por litro de água, com ou sem anelamento feito após a frutificação. Todos os tratamentos aumentaram a massa média de cachos quando comparados com os controles não tratados. A aplicação de $2 \mathrm{mg}$ de ácido giberélico por litro mais anelamento resultou nos maiores valores de massa média de cachos. A massa média de bagos foi maior também neste tratamento conjunto. Os tratamentos não tiveram efeitos significativos no conteúdo de açúcar, acidez ou pH.

Muñoz \& Pezoa (1993) observaram, no Chile, que a combinação do ácido giberélico, aplicado nos cachos quando os bagos apresentavam diâmetro entre 8 e 9mm, com a prática do anelamento de ramos da cultivar Superior Seedless aumentou a massa dos cachos, dos engaços e, também, o diâmetro dos bagos, quando comparados com aqueles cujos tratamentos receberam apenas $\mathrm{GA}_{3}$ ou daqueles em que o anelamento foi realizado isoladamente.

Também no Chile, Gómez Morales (1999) realizou ensaio com a cultivar apirena Crimson Seedless, aplicando ácido giberélico após a frutificação nas doses de 0, 15 e 20ppm isoladamente ou em conjunto com a prática do anelamento. $\mathrm{O}$ autor observou que o diâmetro final dos bagos foi maior à medida que se aumentou a concentração de ácido giberélico aplicado juntamente com o anelamento.

Pommer et al.(1995), estudaram o efeito da incisão anelar, de forma isolada ou em conjunto com ácido giberélico, sobre os cachos e os bagos da cultivar apirena Maria, na região de Jundiaí. O anelamento e o ácido giberélico aumentaram significativamente o número, a massa, o comprimento e a largura dos bagos, e a massa, o comprimento e a largura dos cachos, em comparação com a testemunha. O efeito isolado do ácido giberélico foi superior ao do anelamento em quase todas as características. $\mathrm{O}$ anelamento isolado induziu um teor de sólidos solúveis bastante superior ao dos demais tratamentos. Os melhores resultados foram obtidos com a combinação do anelamento com a 
aplicação do ácido giberélico.

Zabadal (1992), realizou experimentos em Nova York, para avaliar o efeito do anelamento em videiras da cultivar Himrod submetidas à práticas comerciais comuns de aplicações de ácido giberélico e/ou desbaste de frutos. O ácido giberélico foi aplicado nos cachos na dose de 20ppm quando $50 \%$ das flores estavam abertas e novamente na dose de 50ppm logo após a queda natural de bagos. Ele observou que o anelamento aumentou a massa dos cachos, o número de bagos/cachos e a massa dos bagos em até 106, 138 e 17\%, respectivamente. Embora o anelamento tenha aumentado em 66\% a produção, houve uma redução no teor de sólidos solúveis. Portanto, em condições de clima ameno, para que o anelamento aumente a qualidade da produção, é necessário que seja realizado um desbaste de frutos adequado para se obter um teor de sólidos solúveis aceitável.

Harrel \& Williams (1987) observaram a influência do anelamento e da aplicação de 40ppm de ácido giberélico na frutificação das cultivares Ruby Seedless e Thompson Seedless. O anelamento aumentou a massa média dos bagos em ambas as cultivares e reduziu o teor de sólidos solúveis na colheita. A produção foi significativamente maior com o anelamento. O ácido giberélico aumentou a massa dos bagos apenas na cultivar Ruby Seedless. O teor de sólidos solúveis foi maior em todos os frutos que foram tratados com o ácido giberélico. Já, Colapietra et al. (1996), na Itália, trabalhando com a cultivar Centennial Seedless, estudaram o efeito do anelamento e da aplicação de 20 ou 40ppm de ácido giberélico e concluíram que o regulador vegetal aumentou o comprimento dos bagos, mas reduziu o teor de sólidos solúveis, ao passo que o anelamento não teve qualquer efeito sobre as dimensões dos bagos mas aumentou o acúmulo de açúcares e adiantou o amadurecimento.

Verificando-se a revisão de literatura, pode-se notar diferentes respostas às práticas adotadas, justificando a necessidade de novas pesquisas no sentido de se obter a concentração adequada de ácido giberélico combinada ou não com a prática da incisão anelar, em função da cultivar e das condições climáticas de cada região. 


\section{MATERIAL E MÉTODOS}

No período compreendido entre março de 1999 a junho 2000 foram realizados quatro experimentos, sendo dois com a cultivar Niagara Rosada, no município de Junqueirópolis, e dois com a cultivar Vênus, nos municípios de Jales e Urânia (Quadro $1)$.

\begin{tabular}{lcccc}
\hline Cultivar & Local & $\begin{array}{c}\text { Data da } \\
\text { poda }\end{array}$ & $\begin{array}{c}\text { Aplicação dos } \\
\text { tratamentos }\end{array}$ & $\begin{array}{c}\text { Data da } \\
\text { Colheita }\end{array}$ \\
\hline Niagara Rosada $^{1}$ & Junqueirópolis & $13 / 2 / 99$ & $25 / 3 / 99$ & $26 / 05 / 99$ \\
Niagara Rosada $^{2}$ & Junqueirópolis & $17 / 9 / 99$ & $4 / 11 / 99$ & $12 / 1 / 2000$ \\
Vênus $^{3}$ & Jales & $28 / 7 / 99$ & $16 / 09 / 99$ & $28 / 10 / 99$ \\
Vênus $^{4}$ & Urânia & $02 / 03 / 00$ & $12 / 04 / 00$ & $26 / 06 / 00$ \\
\hline
\end{tabular}

Quadro 1. Experimentos instalados no período de março de 1999 a junho de 2000

${ }^{1}$ - Primeiro ciclo de $1999 ;{ }^{2}$ - Segundo ciclo de $1999 ;{ }^{3}$ - Ciclo vegetativo de $1999 ;{ }^{4}$ - Ciclo vegetativo de 2000.

\subsection{Experimentos com a cultivar Niagara Rosada}

Os dois experimentos realizados com a cultivar Niagara Rosada, sendo um no primeiro ciclo vegetativo de 1999 e o outro no segundo ciclo vegetativo deste mesmo ano, foram conduzidos em vinhedo comercial de propriedade do Sr. Adalberte Stivari, localizado no município de Junqueirópolis, SP. O solo é caracterizado como podzólico vermelho-amarelo. Do ponto de vista climático, a região está classificada como uma transição entre Aw e Cfa, de acordo com o sistema proposto por Köeppen. 
As videiras em estudo estavam com 2 anos de idade, enxertadas sobre o portaenxerto IAC 766 'Campinas', híbrido de 106-8 Mgt-Ripária do Traviú x Vitis caribaea, conduzidas em latada, no espaçamento de $2 \times 2 \mathrm{~m}$.

\subsubsection{Experimento com a cultivar Niagara Rosada realizado no primeiro ciclo vegetativo de 1999}

No experimento realizado no primeiro ciclo vegetativo de 1999, as plantas de Niagara Rosada foram podadas em 13 de fevereiro de 1999. O florescimento ocorreu em 10 de março de 1999 e os tratamentos foram realizados 15 dias após o florescimento, portanto, em 25 de março de 1999, no período das 14:00 às 18:00 horas. A colheita ocorreu em 26 de maio de 1999.

Os tratamentos realizados foram os seguintes:

1) Testemunha sem ramos anelados e sem imersão dos cachos em solução de ácido giberélico.

2) Ramos anelados sem imersão dos cachos em solução de ácido giberélico (Figura 1).

3) Cachos imersos em solução de ácido giberélico a 10ppm.

4) Cachos imersos em solução de ácido giberélico a 22,5ppm.

5) Cachos imersos em solução de ácido giberélico a 35ppm.

6) Cachos imersos em solução de ácido giberélico a 47,5ppm.

7) Cachos imersos em solução de ácido giberélico a 60ppm.

8) Cachos imersos em solução de ácido giberélico a 72,5ppm.

9) Ramos anelados com cachos imersos em solução de ácido giberélico a 10ppm.

10) Ramos anelados com cachos imersos em solução de ácido giberélico a $22,5 \mathrm{ppm}$.

11) Ramos anelados com cachos imersos em solução de ácido giberélico a $35 \mathrm{ppm}$.

12) Ramos anelados com cachos imersos em solução de ácido giberélico a 47,5ppm.

13) Ramos anelados com cachos imersos em solução de ácido giberélico a 
60ppm.

14) Ramos anelados com cachos imersos em solução de ácido giberélico a $72,5 \mathrm{ppm}$.

O delineamento estatístico foi em blocos ao acaso com 14 tratamentos, 5 repetições e 4 ramos produtivos ( 1 cacho/ ramo) por parcela, totalizando 280 cachos.

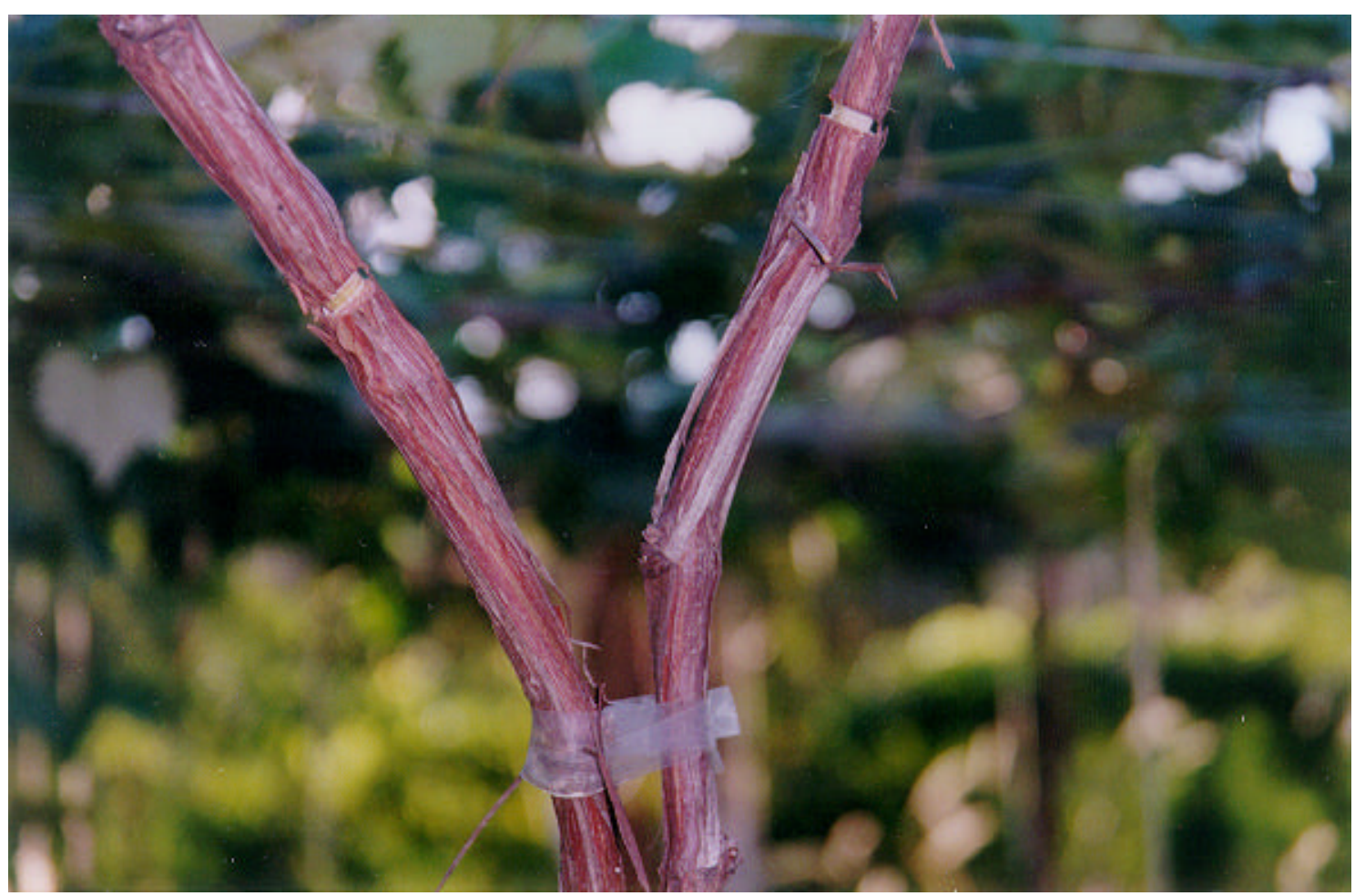

Figura 1 - Anelamento em ramos.

\subsubsection{Experimento com a cultivar Niagara Rosada realizado no segundo ciclo vegetativo de 1999}

No segundo ciclo vegetativo de 1999, as plantas de Niagara Rosada foram podadas em 17 de setembro de 1999, ocorrendo o florescimento em 17 de outubro de 1999 e a aplicação dos tratamentos em 04 de novembro de 1999, no período das 14:00 às 16:30 horas. A colheita dos cachos foi realizada em 12 de janeiro de 2000.

Os tratamentos obedeceram ao seguinte esquema:

1) Testemunha sem ramos anelados e sem imersão dos cachos em solução de ácido giberélico. 
2) Ramos anelados sem imersão dos cachos em solução de ácido giberélico.

3) Cachos imersos em solução de ácido giberélico a 10ppm.

4) Cachos imersos em solução de ácido giberélico a 22,5ppm.

5) Cachos imersos em solução de ácido giberélico a 35ppm.

6) Cachos imersos em solução de ácido giberélico a 47,5ppm.

7) Cachos imersos em solução de ácido giberélico a 60ppm.

8) Cachos imersos em solução de ácido giberélico a 72,5ppm.

9) Cachos imersos em solução de ácido giberélico a 85ppm.

10) Cachos imersos em solução de ácido giberélico a 97,5ppm.

11) Ramos anelados com cachos imersos em solução de ácido giberélico a $10 \mathrm{ppm}$.

12) Ramos anelados com cachos imersos em solução de ácido giberélico a 22,5ppm.

13) Ramos anelados com cachos imersos em solução de ácido giberélico a $35 \mathrm{ppm}$.

14) Ramos anelados com cachos imersos em solução de ácido giberélico a 47,5ppm.

15) Ramos anelados com cachos imersos em solução de ácido giberélico a $60 \mathrm{ppm}$.

16) Ramos anelados com cachos imersos em solução de ácido giberélico a $72,5 \mathrm{ppm}$.

17) Ramos anelados com cachos imersos em solução de ácido giberélico a $85 \mathrm{ppm}$.

18) Ramos anelados com cachos imersos em solução de ácido giberélico a 97,5ppm.

O delineamento estatístico utilizado foi em blocos ao acaso, com 18 tratamentos, 5 repetições, sendo cada parcela constituída por 4 ramos produtivos (1 cacho/ ramo), totalizando 360 cachos. 


\subsection{Experimentos com a cultivar Vênus}

Foram realizados dois experimentos com a cultivar Vênus, um durante o ciclo vegetativo de 1999 e o outro durante o ciclo de 2000. Nos dois experimentos as plantas em estudo estavam enxertadas sobre o porta-enxerto IAC-572 'Jales', híbrido de $V$. caribaea e V. ripária x V. ruprestis 101-14.

Nos experimentos com a cultivar Vênus além da aplicação do ácido giberélico e da realização do anelamento de ramos, efetuourse, também, a prática do desponte de cachos, que consiste do corte das pontas dos cachos, visando melhor aparência e melhor acondicionamento dos cachos de cultivares que apresentam a ponta afilada (Sousa, 1996), como é o caso desta cultivar, o que dificulta a embalagem e as tornam menos atraentes. O desponte foi realizado no momento da aplicação do ácido giberélico, quando os bagos apresentavam de 4-6mm de diâmetro.

Foram realizados os seguintes tratamentos:

1) Testemunha sem ramos anelados, sem imersão dos cachos em solução de ácido giberélico e sem desponte de cachos.

2) Ramos anelados sem imersão dos cachos em solução de ácido giberélico e sem desponte de cachos

3) Desponte de cachos sem ramos anelados, sem imersão dos cachos em solução de ácido giberélico.

4) Ramos anelados e desponte de cachos.

5) Cachos imersos em solução de ácido giberélico a 10ppm.

6) Cachos imersos em solução de ácido giberélico a 22,5ppm.

7) Cachos imersos em solução de ácido giberélico a 35ppm.

8) Cachos imersos em solução de ácido giberélico a 47,5ppm.

9) Cachos imersos em solução de ácido giberélico a 60ppm.

10) Cachos imersos em solução de ácido giberélico a 72,5ppm.

11) Ramos anelados com cachos imersos em solução de ácido giberélico a 10ppm.

12) Ramos anelados com cachos imersos em solução de ácido giberélico a 22,5ppm. 
13) Ramos anelados com cachos imersos em solução de ácido giberélico a $35 \mathrm{ppm}$.

14) Ramos anelados com cachos imersos em solução de ácido giberélico a 47,5ppm.

15) Ramos anelados com cachos imersos em solução de ácido giberélico a $60 \mathrm{ppm}$.

16) Ramos anelados com cachos imersos em solução de ácido giberélico a $72,5 \mathrm{ppm}$.

17) Desponte de cachos e imersão em solução de ácido giberélico a 10ppm.

18) Desponte de cachos e imersão em solução de ácido giberélico a 22,5ppm.

19) Desponte de cachos e imersão em solução de ácido giberélico a 35ppm.

20) Desponte de cachos e imersão em solução de ácido giberélico a 47,5ppm.

21) Desponte de cachos imersão em solução de ácido giberélico a 60ppm.

22) Desponte de cachos e imersão em solução de ácido giberélico a 72,5ppm.

23) Desponte de cachos, ramos anelados e cachos imersos em solução de ácido giberélico a 10ppm.

24) Desponte de cachos, ramos anelados e cachos imersos em solução de ácido giberélico a 22,5ppm.

25) Desponte de cachos, ramos anelados e cachos imersos em solução de ácido giberélico a $35 \mathrm{ppm}$.

26) Desponte de cachos, ramos anelados e cachos imersos em solução de ácido giberélico a 47,5ppm.

27) Desponte de cachos, ramos anelados e cachos imersos em solução de ácido giberélico a 60ppm.

28) Desponte de cachos, ramos ane lados e cachos imersos em solução de ácido giberélico a 72,5ppm.

O delineamento estatístico utilizado foi em blocos ao acaso, com 28 tratamentos, 5 repetições, sendo cada parcela constituída por 4 ramos produtivos ( 1 cacho/ ramo), totalizando 560 cachos. 


\subsubsection{Experimento com a cultivar Vênus realizado no Ciclo Vegetativo de 1999}

Esse primeiro experimento com a cultivar Vênus foi realizado na Unidade Experimental do Centro Nacional de Pesquisa de Uva e Vinho da EMBRAPA, localizada no município de Jales, SP, em solo podzólico vermelho-amarelo. De acordo com o sistema proposto por Köeppen a região, sob o aspecto climático, é classificada como Aw.

As plantas em estudo estavam com 5 anos de idade, enxertadas sobre o portaenxerto IAC 572, conduzidas no sistema de latada, no espaçamento de 5 x 3m.

As podas das videiras foram realizadas em 28 de julho de 1999, o florescimento ocorreu em $1^{\circ}$ de setembro de 1999. Os tratamentos citados anteriormente foram realizados em 16 de setembro de 1999, no período das 13:00 às 17:00 horas. A colheita dos cachos ocorreu em 28 de outubro de 1999 (Figuras 2 e 3).

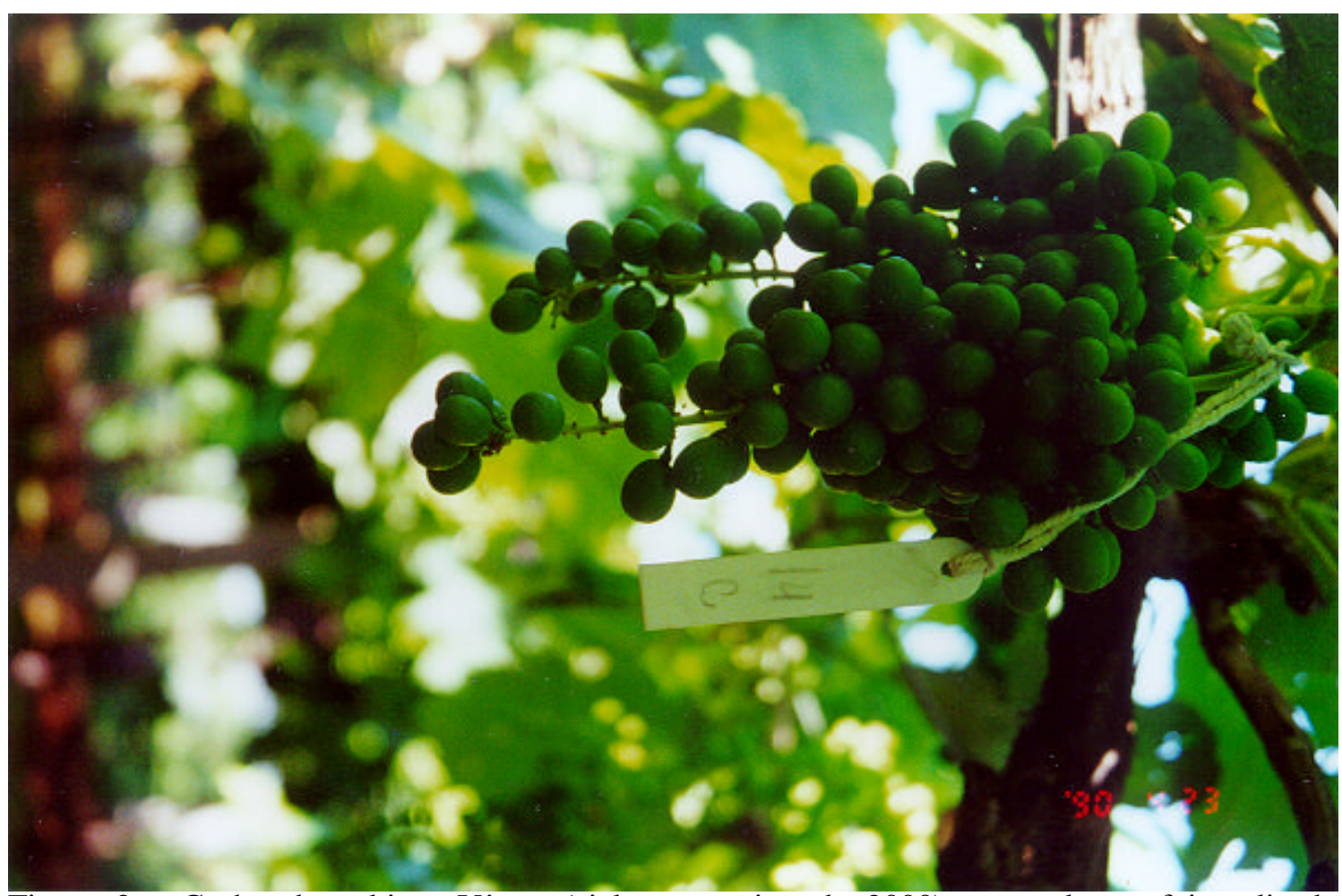

Figura 2 - Cacho da cultivar Vênus (ciclo vegetativo de 2000) no qual não foi realizado desponte. 


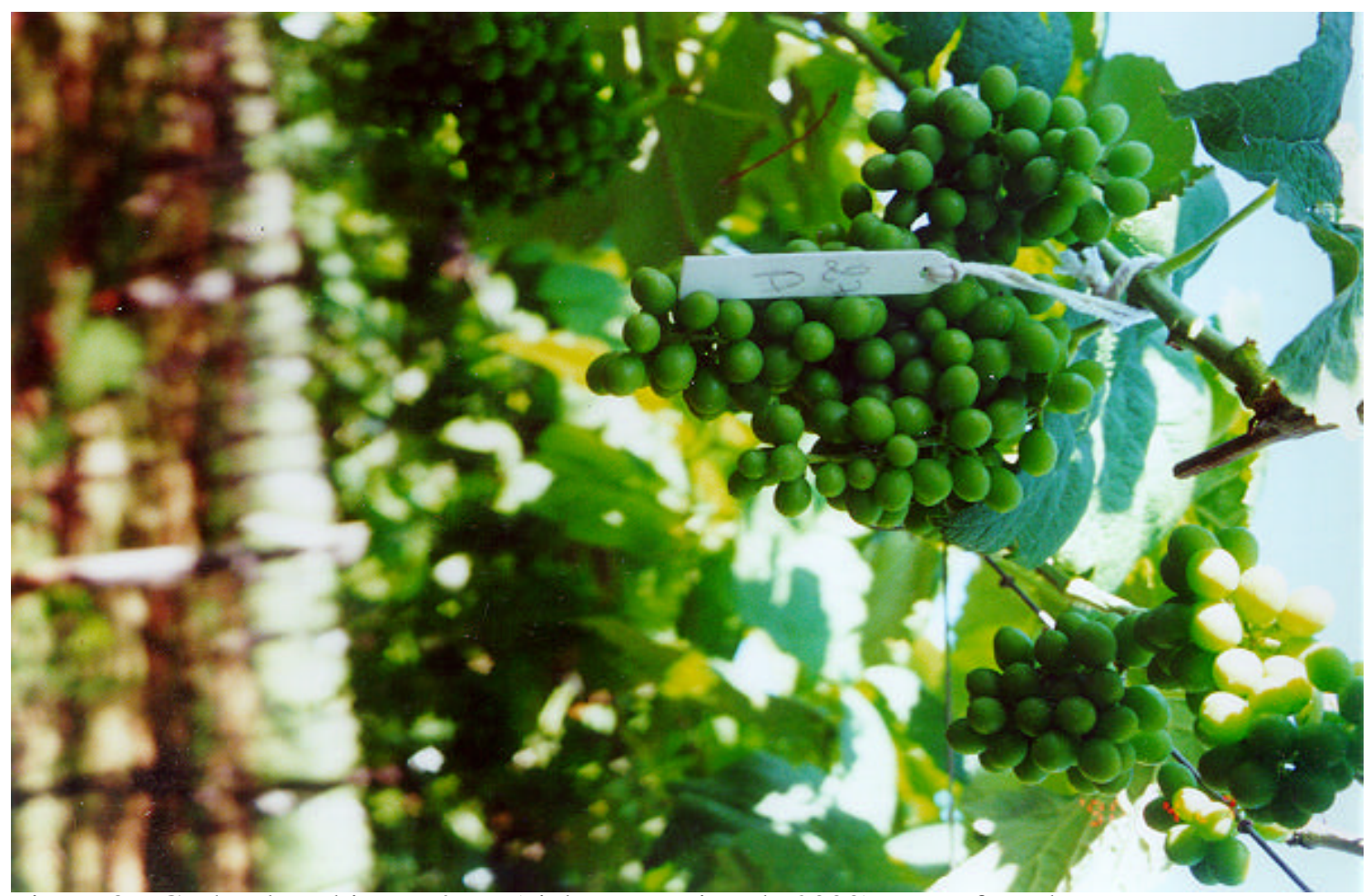

Figura 3 - Cacho da cultivar Vênus (ciclo vegetativo de 2000) que sofreu desponte.

\subsubsection{Experimento com a cultivar Vênus realizado no ciclo vegetativo de 2000}

Este experimento foi realizado em vinhedo comercial de propriedade do Sr.

Cícero Lourenço de Paula, Sítio Santa Rosa, localizado no município de Urânia, SP. Segundo proposto por Köeppen a região, sob o aspecto climático, é classificada como Aw. O solo da região está classificado como podzólico vermelho-amarelo.

As plantas em estudo estavam no $3^{\circ}$ ciclo de produção, enxertadas sobre o portaenxerto IAC 572, cond uzidas no sistema de latada, no espaçamento de 5 x $2 \mathrm{~m}$.

As podas das videiras foram realizadas em 02 de março de 2000, o florescimento pleno ocorreu em 29 de março de 2000. Os tratamentos foram realizados em 12 de abril de 2000, no período das 14:00 às 18:00 horas. A colheita dos cachos ocorreu em 26 de junho de 2000.

Nos quatro experimentos realizados, utilizou-se como fonte de giberelina o Pro- 
Gibb, produto comercial embalado e comercializado pela Divisão de Produtos Agropecuários da Abbott Laboratórios do Brasil Ltda, em que $10 \mathrm{~g}$ do produto corresponde a $1 \mathrm{~g}$ de ácido giberélico. Como espalhante adesivo foi utilizado o Iharaden 'S, na concentração de $0,3 \mathrm{ml} / \mathrm{L}$ de solução.

A aplicação de ácido giberélico, realizada quinze dias após o pleno florescimento, baseou-se na imersão total dos cachos, por dez segundos. Foram imersos 4 cachos por tratamento.

O anelamento foi efetuado nos ramos produtivos, na mesma época da aplicação do ácido giberélico, com incisor de lâmina dupla, tipo alicate, com largura de corte de 4,7mm. Foram anelados 4 ramos produtivos por tratamento.

O desponte foi realizado no momento da aplicação do ácido giberélico, quando os bagos da cultivar Vênus apresentavam de 4-6mm de diâmetro.

Após completado o ciclo da cultura, efetuourse a colheita dos cachos marcados, que foram acondicionados em sacos de polietileno e armazenados em câmara frigorífica à temperatura de $2^{\circ} \mathrm{C}$ com $90 \%$ de umidade relativa, onde permaneceram até a completa avaliação das seguintes características:

1-Massa, largura e comprimento dos cachos.

2-Massa, largura e comprimento dos engaços.

3-Massa, largura e comprimento dos bagos, e diâmetro dos pedicelos.

4-Número de bagos por cacho.

5-Massa média de 30 bagos subamostrados por cacho.

6-Teor de sólidos solúveis.

\section{7-Acidez titulável}

As medidas lineares dos cachos e engaços foram obtidas utilizando-se régua milimetrada; as medidas lineares dos bagos foram tomadas em um paquímetro digital; a massa dos cachos, engaços e bagos foram determinadas em uma balança de precisão. $\mathrm{O}$ teor de sólidos solúveis totais foi obtido através do uso de refratômetro de bancada. A acidez titulável expressa em gramas de ácido tartárico por $100 \mathrm{ml}$ de mosto, foi obtida através da titulação de uma amostra de $5 \mathrm{ml}$ de mosto com solução de hidróxido de sódio a $0,1 \mathrm{~N}$. 


\section{RESULTADOS E DISCUSSÃO}

Nos quatro experimentos realizados os dados foram submetidos à análises de variância pelo programa SAS, aplicando-se teste de Tukey para se comparar o efeito do anelamento e/ou desponte entre as médias dos tratamentos. Para se comparar o efeito de doses de ácido giberélico entre as médias dos tratamentos optou-se por fazer regressão polinomial.

\subsection{Experimentos com a cultivar Niagara Rosada}

\subsection{1 'Niagara Rosada' - Primeiro ciclo vegetativo de 1999}

O delineamento experimental foi em blocos ao acaso com 14 tratamentos e 5 repetições no esquema fatorial 2x7. Houve a combinação dos dois seguintes fatores: 1) com anelamento ou sem anelamento e 2) doses de ácido giberélico (Quadro 2).

\begin{tabular}{|l|l|}
\hline \multicolumn{2}{|l|}{ Anelamento } \\
\hline $\begin{array}{l}\text { Anel } 1 \\
\text { Anel } 2\end{array}$ & $\begin{array}{l}\text { Sem anelamento } \\
\text { Com anelamento }\end{array}$ \\
\hline Doses \\
\hline Dose 1 & Oppm \\
Dose 2 & $10 \mathrm{ppm}$ \\
Dose 3 & $22,5 \mathrm{ppm}$ \\
Dose 4 & $35 \mathrm{ppm}$ \\
Dose 5 & $47,5 \mathrm{ppm}$ \\
Dose 6 & 60ppm \\
Dose 7 & $72,5 \mathrm{ppm}$ \\
\hline
\end{tabular}


Nas Tabelas 1 e 2 são apresentados os resultados das análises estatísticas para os parâmetros avaliados nos cachos da cultivar Niagara Rosada durante o primeiro ciclo vegetativo de 1999.

Tabela 1. Aplicação do Teste "F" para as características mensuradas nos cachos da cultivar Niagara Rosada durante o primeiro ciclo vegetativo de 1999.

\begin{tabular}{lllll}
\hline $\begin{array}{l}\text { Causas da } \\
\text { Variação }\end{array}$ & $\begin{array}{l}\text { Comprimento de } \\
\text { cachos }(\mathrm{cm})\end{array}$ & $\begin{array}{l}\text { Largura de } \\
\text { cachos }(\mathrm{cm})\end{array}$ & $\begin{array}{l}\text { Massa de cachos } \\
(\mathrm{g}) \\
\text { Teste “F” }\end{array}$ & $\begin{array}{l}\text { Número de } \\
\text { bagos/cacho }\end{array}$ \\
\hline Anelamento & $0,107 \mathrm{~ns}{ }^{(1)}$ & $1,263 \mathrm{~ns}$ & $0,121 \mathrm{~ns}$ & $5,684^{*}$ \\
Doses de GA3 & $2,378^{*}{ }^{(2)}$ & $4,951^{* *}{ }^{(3)}$ & $8,399^{* *}$ & $2,074 \mathrm{~ns}$ \\
Interação & $1,628 \mathrm{~ns}$ & $1,767 \mathrm{~ns}$ & $1,554 \mathrm{~ns}$ & $1,539 \mathrm{~ns}$ \\
AnelxGA3 & & & \\
(1) Não significativo ao nível de 5\% de probabilidade. & & \\
${ }^{(2)}$ Significativo ao nível de 5\% de probabilidade. & & \\
${ }^{(3)}$ Significativo ao nível de 1\% de probabilidade.
\end{tabular}

Como pode-se observar na Tabela 1, para os parâmetros avaliados nos cachos, a interação entre os fatores não foi significativa, portanto os efeitos foram avaliados isoladamente, realizando-se assim teste de Tukey para se comparar o efeito do anelamento entre as médias dos tratamentos e regressão polinomial (Tabela 2) para verificar o efeito de doses de ácido giberélico entre as médias dos tratamentos.

Tabela 2. Aplicação do teste de Tukey e de regressão polinomial para o comprimento médio, a largura média e a massa média dos cachos e o número médio de bagos por cacho da cultivar Niagara Rosada durante o primeiro ciclo vegetativo de 1999 .

\begin{tabular}{|c|c|c|c|c|}
\hline \multirow[b]{2}{*}{ Causas da Variação } & \multicolumn{4}{|c|}{ Teste de Tukey para as médias de anelamento } \\
\hline & $\begin{array}{l}\text { Comprimento } \\
\text { de cachos }(\mathrm{cm})\end{array}$ & $\begin{array}{l}\text { Largura de } \\
\text { cachos }(\mathrm{cm})\end{array}$ & $\begin{array}{l}\text { Massa de } \\
\text { cachos (g) }\end{array}$ & $\begin{array}{c}\text { N. }{ }^{\circ} \text { de } \\
\text { bagos/cacho }\end{array}$ \\
\hline Sem anelamento (A1) & 11,96 a $A^{(1)}$ & 7,235 a $\mathrm{A}$ & 199,786 a $\mathrm{A}$ & 54,19 a $\mathrm{A}$ \\
\hline Com anelamento (A2) & 11,91 a $\mathrm{A}$ & 7,102 a $\mathrm{A}$ & 201,300 a $\mathrm{A}$ & $50,72 \mathrm{~b} \mathrm{~A}$ \\
\hline \multicolumn{5}{|c|}{ Regressão Polinomial para as doses de Ácido Giberélico } \\
\hline Efeito Linear & $1,071 \mathrm{~ns}^{(2)}$ & $4,588 *(3)$ & $13,955^{* *}$ & $0,939 \mathrm{~ns}$ \\
\hline Efeito Quadrático & $9,242 * *$ & $11,614 * *(4)$ & $27,731 * *$ & $3,459 \mathrm{~ns}$ \\
\hline $\begin{array}{l}\text { (1) Médias dentro de uma } \\
\text { significativamente ao n } \\
\text { (2) Não significativo ao níve } \\
\text { (3) Significativo ao nível de } \\
\text { (4) Significativo ao nível de }\end{array}$ & $\begin{array}{l}\text { una seguidas de } \\
\text { de } 5 \% \text { e } 1 \% \text { de } p \\
5 \% \text { de probabili } \\
\text { de probabilidade } \\
\text { de probabilidade }\end{array}$ & $\begin{array}{l}\text { a mesma let } \\
\text { abilidade, res }\end{array}$ & $\begin{array}{l}\text { aúscula ou } \\
\text { amente. }\end{array}$ & lla não dif \\
\hline
\end{tabular}


Avaliando isoladamente cada um dos fatores nota-se que o anelamento de ramos não afetou significativamente o comprimento, a largura e a massa média dos cachos (Tabela 2), resultados estes discordantes dos constatados por Zabadal (1992), que obteve cachos significativamente mais pesados quando as videiras foram submetidas ao anelamento, e também, por Kalil et al. (1999) que obteve cachos 48,9\% mais compridos e 56,1\% mais largos com o anelamento de ramos. Porém, verifica-se, que há efeito da aplicação de ácido giberélico sobre estas mesmas características.

Já, o número médio de bagos por cacho não foi afetado pelas diferentes doses de ácido giberélico, mas sofreu influência do anelamento de ramos, sendo que, esta técnica diminuiu o número médio de bagos por cacho (Tabela 2), ao contrário do reportado por Kalil et al. (1999), que obteve um aumento significativo nesta característica como conseqüência do anelamento e/ou a aplicação do ácido giberélico.

Analisando o efeito de doses de ácido giberélico sobre o comprimento médio dos cachos (Figura 4), verifica-se que cachos mais compridos foram obtidos com as doses de $35 \mathrm{ppm}(12,46 \mathrm{~cm})$ e 47,5ppm $(12,24 \mathrm{~cm})$, notando-se em seguida uma diminuição nesses valores com o aumento das doses. Trabalhando com a mesma cultivar, porém, na região de Jundiaí, Pereira et al.(1979) obtiveram cachos mais compridos com a aplicação de 100ppm deste mesmo regulador vegetal sendo realizada 12 dias antes e 7 dias após o florescimento. 


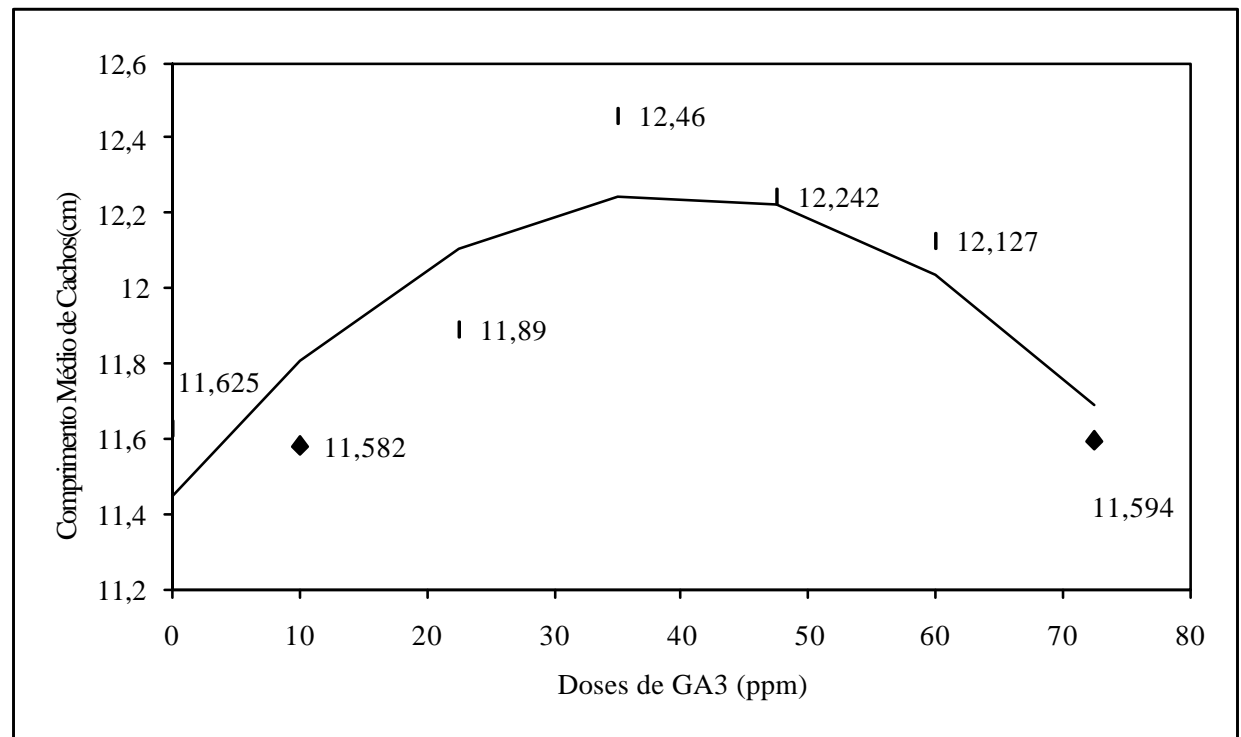

Figura 4 - Efeito de diferentes doses de ácido giberélico, sobre o comprimento médio dos cachos da cultivar Niagara Rosada, durante o primeiro ciclo vegetativo de 1999.

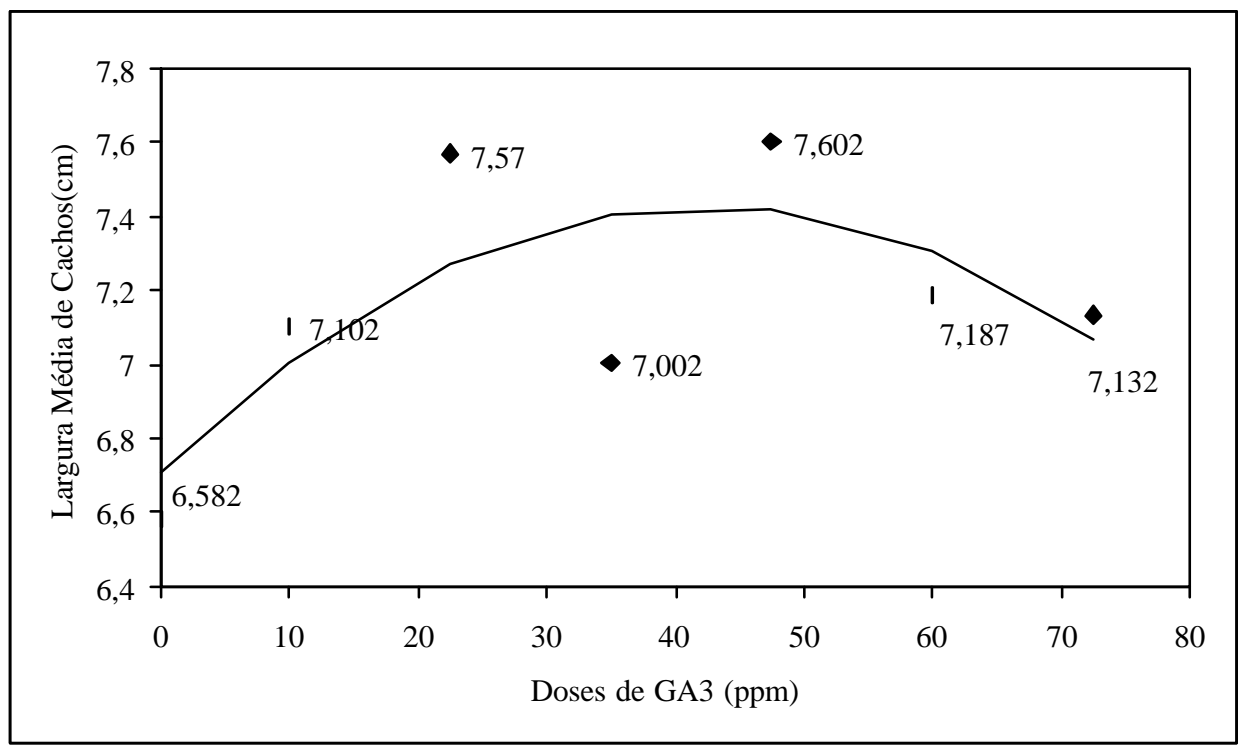

Figura 5 - Efeito de diferentes doses de ácido giberélico, sobre a largura média dos cachos da cultivar Niagara Rosada, durante o primeiro ciclo vegetativo de 1999.

Na Figura 5 observa-se uma tendência de aumento na largura dos cachos até a dose de 47,5ppm, havendo em seguida uma diminuição nestes valores. 
A dose de 0ppm apresentou cachos com 6,582cm de largura, as doses de 22,5; 35 e 47,5ppm apresentaram as seguintes larguras médias de cachos: 7,57cm; 7,00cm e $7,60 \mathrm{~cm}$, respectivamente.

Verifica-se na Figura 6 que a dose de 35ppm originou a maior massa média de cachos, 218,92g, sendo esta $29,4 \%$ maior que a massa média do tratamento-controle (Oppm). Os tratamentos com 22,5 e 47,5ppm apresentaram massas médias de 212 e 210,62g, respectivamente. No município de Jundiaí, Castro (1975) constatou aumento nesta característica com a aplicação de 100ppm de ácido giberélico em pós florescimento. Isto mostra que, a ação dos reguladores vegetais sofre influências de fatores climáticos e de épocas de aplicação.

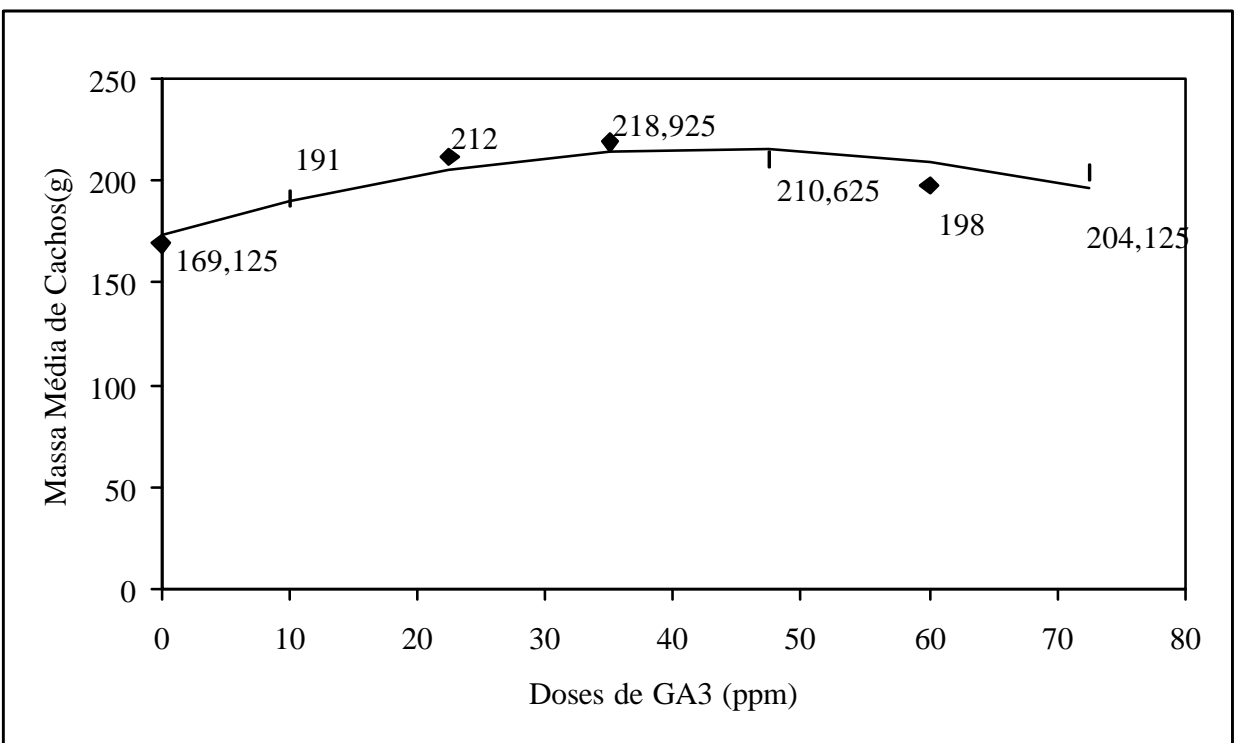

Figura 6 - Efeito de diferentes doses de ácido giberélico, sobre a massa média dos cachos da cultivar Niagara Rosada, durante o primeiro ciclo vegetativo de 1999.

Nas Tabelas 3, 4 e 5 são apresentados os resultados das análises estatísticas para os parâmetros avaliados nos engaços da cultivar Niagara Rosada durante o primeiro ciclo vegetativo de 1999. 


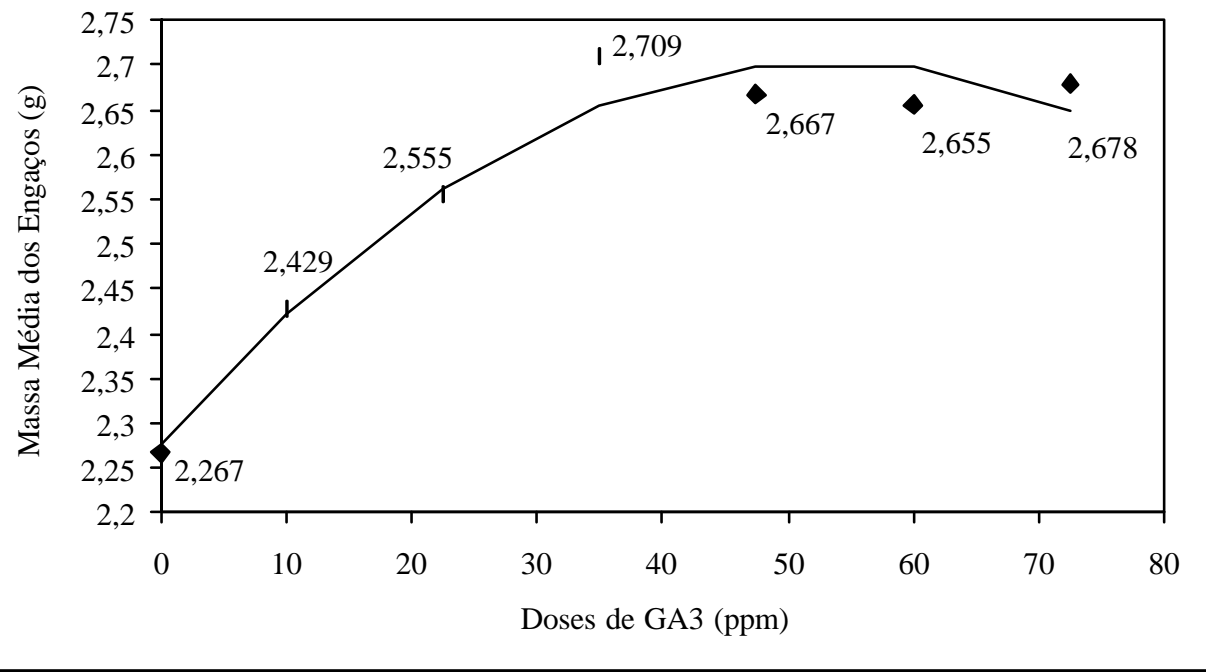

Figura 7 - Efeito de diferentes doses de ácido giberélico, sobre a massa média dos engaços da cultivar Niagara Rosada, durante o primeiro ciclo vegetativo de 1999.

Tabela 5. Aplicação do teste de Tukey e de regressão polinomial para o diâmetro médio dos pedicelos da cultivar Niagara Rosada durante o primeiro ciclo vegetativo de 1999.

\section{Causas da Variação Teste de Tukey para as médias de anelamento dentro das doses de}

GA3

\begin{tabular}{llc}
\hline Doses de GA3 & Sem Anelamento (A1) & Com Anelamento (A2) \\
Oppm & $4,234 \mathrm{aA}$ & $3,891 \mathrm{bB}$ \\
$\mathbf{1 0 , 0 p p m}$ & $4,239 \mathrm{bA}$ & $4,484 \mathrm{aA}$ \\
$\mathbf{2 2 , 5 p p m}$ & $4,332 \mathrm{aA}{ }^{(1)}$ & $4,485 \mathrm{aA}$ \\
$\mathbf{3 5 , 0 p p m}$ & $4,341 \mathrm{aA}$ & $4,544 \mathrm{aA}$ \\
$\mathbf{4 7 , 5 p p m}$ & $3,788 \mathrm{bB}$ & $4,630 \mathrm{aA}$ \\
$\mathbf{6 0 , 0 p p m}$ & $4,234 \mathrm{aA}$ & $4,006 \mathrm{bA}$ \\
$\mathbf{7 2 , 5 p p m}$ & $4,341 \mathrm{aA}$ & $4,393 \mathrm{aA}$ \\
& Regressão Polinomial para as doses de Ácido Giberélico dentro dos \\
& \multicolumn{2}{c}{ níveis do fator anelamento } \\
& Sem Anelamento(A1) Com Anelamento (A2) \\
Efeito Line ar & $0,331 \mathrm{~ns}{ }_{(2)}$ & Com \\
Efeito Quadrático & $3,136 \mathrm{~ns}$ & $30,913^{* *}{ }^{(3)}$ \\
\hline
\end{tabular}

(1) Médias dentro de uma linha seguidas de uma mesma letra minúscula ou maiúscula não diferem significativamente ao nível de $5 \%$ e $1 \%$ de probabilidade, respectivamente.

${ }^{(2)}$ Não significativo ao nível de $5 \%$ de probabilidade.

${ }^{(3)}$ Significativo ao nível de $1 \%$ de probabilidade. 
Com relação ao diâmetro médio dos pedicelos, somente quando as duas técnicas são realizadas conjuntamente é que se observa efeito significativo de doses de ácido giberélico (Tabela 5), sendo o maior diâmetro observado com a doses de 47,5ppm $(4,63 \mathrm{~mm})$ sendo aplicada juntamente com o anelamento de ramos (Figura 8).

Vale também notar que o tratamento-controle (0ppm) apresentou diâmetro médio de pedicelo inferior àqueles em que o ácido giberélico foi aplicado (Figura 8). Estes resultados concordam com diversos autores (Pereira \& Oliveira, 1976; Retamales et al., 1993) que obtiveram engrossamento dos pedicelos com a aplicação de ácido giberélico.

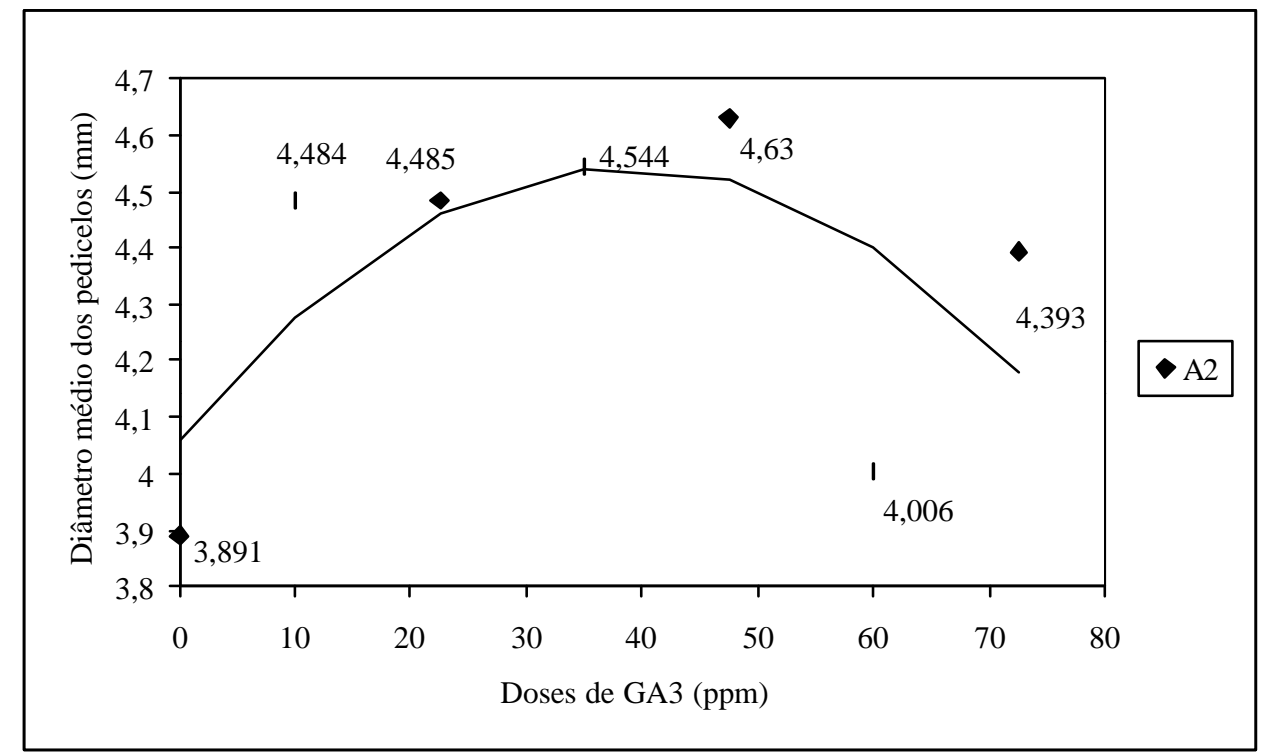

Figura 8 - Efeito da aplicação de diferentes doses de ácido giberélico, realizada juntamente com a prática do anelamento de ramos, sobre o diâmetro médio dos pedicelos da cultivar Niagara Rosada, durante o primeiro ciclo vegetativo de 1999.

Nas Tabelas de 6 a 11 são apresentados os resultados das análises estatísticas para os parâmetros avaliados nos bagos da cultivar Niagara Rosada durante o primeiro ciclo vegetativo de 1999. 
Tabela 6. Aplicação do Teste "F" para as características mensuradas nos bagos da cultivar Niagara Rosada durante o primeiro ciclo vegetativo de 1999.

\begin{tabular}{llllll}
\hline $\begin{array}{l}\text { Causas da } \\
\text { Variação }\end{array}$ & $\begin{array}{l}\text { Comprimento } \\
\text { de bagos }(\mathrm{mm})\end{array}$ & $\begin{array}{l}\text { Largura de } \\
\text { bagos }(\mathrm{mm})\end{array}$ & $\begin{array}{c}\text { Massa média } \\
\text { de bagos }(\mathrm{g}) \\
\text { Teste “F” }\end{array}$ & $\begin{array}{l}\text { Acidez } \\
\text { Titulável }\end{array}$ & TSS $^{(3)}\left({ }^{\circ}\right.$ Brix) \\
\hline Anelamento & $27,236^{* *}{ }^{(2)}$ & $37,014^{* *}$ & $23,152^{* *}$ & $1,047 \mathrm{~ns}{ }^{(1)}$ & $0,831 \mathrm{~ns}$ \\
Doses de GA3 & $26,705^{* *}$ & $17,565^{* *}$ & $13,992^{* *}$ & $4,885^{* *}$ & $6,214^{* *}$ \\
Interação & $11,596^{* *}$ & $7,212^{* *}$ & $6,638^{* *}$ & $9,522^{* *}$ & $6,713^{* *}$ \\
AnelxGA3 & & & & \\
\hline (1) Não significativo ao nível de 5\% de probabilidade. \\
(2) Significativo ao nível de 1\% de probabilidade. \\
${ }^{(3)}$ Teor de sólidos solúveis
\end{tabular}

Houve interação significativa entre os fatores para todas as características avaliadas nos bagos.

Tabela 7. Aplicação do teste de Tukey e de regressão polinomial para o comprimento médio de bagos da cultivar Niagara Rosada durante o primeiro ciclo vegetativo de 1999.

\begin{tabular}{|c|c|c|}
\hline Causas da Variação & \multicolumn{2}{|c|}{$\begin{array}{l}\text { Teste de Tukey para as médias de anelamento dentro das doses de } \\
\text { GA3 }\end{array}$} \\
\hline Doses de GA3 & Sem Anelamento (A1) & Com Anelamento (A2) \\
\hline 0ppm & $19,05 \mathrm{aA}^{(1)}$ & $18,10 \mathrm{bB}$ \\
\hline $10,0 \mathrm{ppm}$ & $19,27 \mathrm{bB}$ & $20,22 \mathrm{aA}$ \\
\hline $22,5 \mathrm{ppm}$ & $19,49 \mathrm{bB}$ & $20,25 \mathrm{aA}$ \\
\hline 35,0ppm & $20,39 \mathrm{aA}$ & $20,78 \mathrm{aA}$ \\
\hline 47,5ppm & $19,15 \mathrm{bB}$ & $20,64 \mathrm{aA}$ \\
\hline $60,0 \mathrm{ppm}$ & $19,73 \mathrm{aA}$ & $19,52 \mathrm{aA}$ \\
\hline \multirow[t]{3}{*}{ 72,5ppm } & $19,76 \mathrm{bB}$ & $20,65 \mathrm{aA}$ \\
\hline & \multicolumn{2}{|c|}{$\begin{array}{c}\text { Regressão Polinomial para as doses de Ácido Giberélico dentro dos } \\
\text { níveis do fator anelamento }\end{array}$} \\
\hline & Sem Anelamento(A1) & Com Anelamento (A2) \\
\hline Efeito Linear & $8,50 * *(3)$ & $50,18 * *$ \\
\hline Efeito Quadrático & $5,08^{*(2)}$ & $55,51 * *$ \\
\hline
\end{tabular}

Como pode-se observar na Tabela 7, o anelamento de ramos potencializou a ação do ácido giberélico quando as doses de 10; 22,5; 47,5 e 72,5ppm foram aplicadas, 
aumentando significativamente o comprimento médio dos bagos. Porém, quando não se aplicou o ácido giberélico, o anelamento de ramos originou bagos com comprimentos menores significativamente. Já, não houve qualquer efeito do anelamento quando as doses de 35 e 60ppm foram aplicadas.

Nas Figuras 9 e 10 pode-se notar que os maiores comprimentos médios de bagos foram obtidos com a dose de 35ppm, sendo aplicada isoladamente (Figura 9) ou conjuntamente com o anelamento de ramos (Figura 10).

Sendo assim, nota-se que para aumentar o comprimento médio dos bagos do cultivar Niagara Rosada, pode-se aplicar a dose de 35ppm de ácido giberélico isoladamente, visto que esta não diferiu estatisticamente quando realizou-se também o anelamento de ramos (Tabela 7).

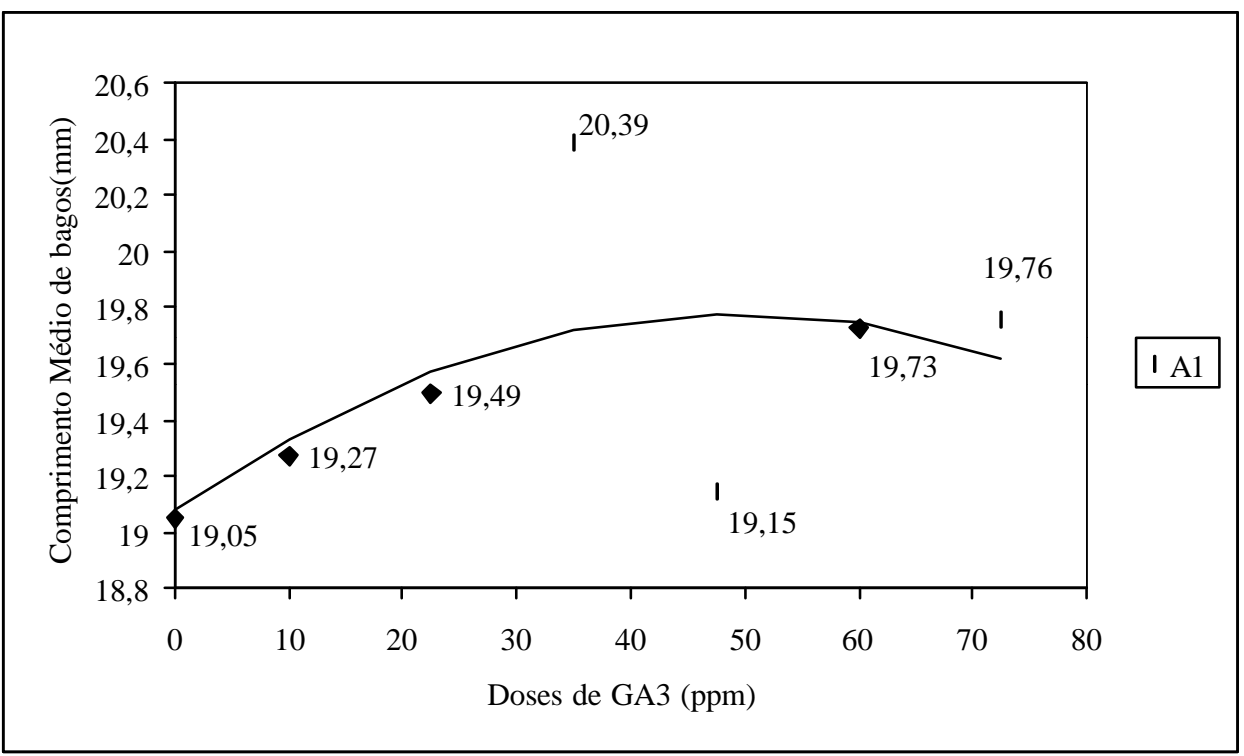

Figura 9 - Efeito da aplicação de diferentes doses de ácido gberélico, realizada isoladamente (sem a prática do anelamento de ramos), sobre o comprimento médio dos bagos da cultivar Niagara Rosada, durante o primeiro ciclo vegetativo de 1999. 


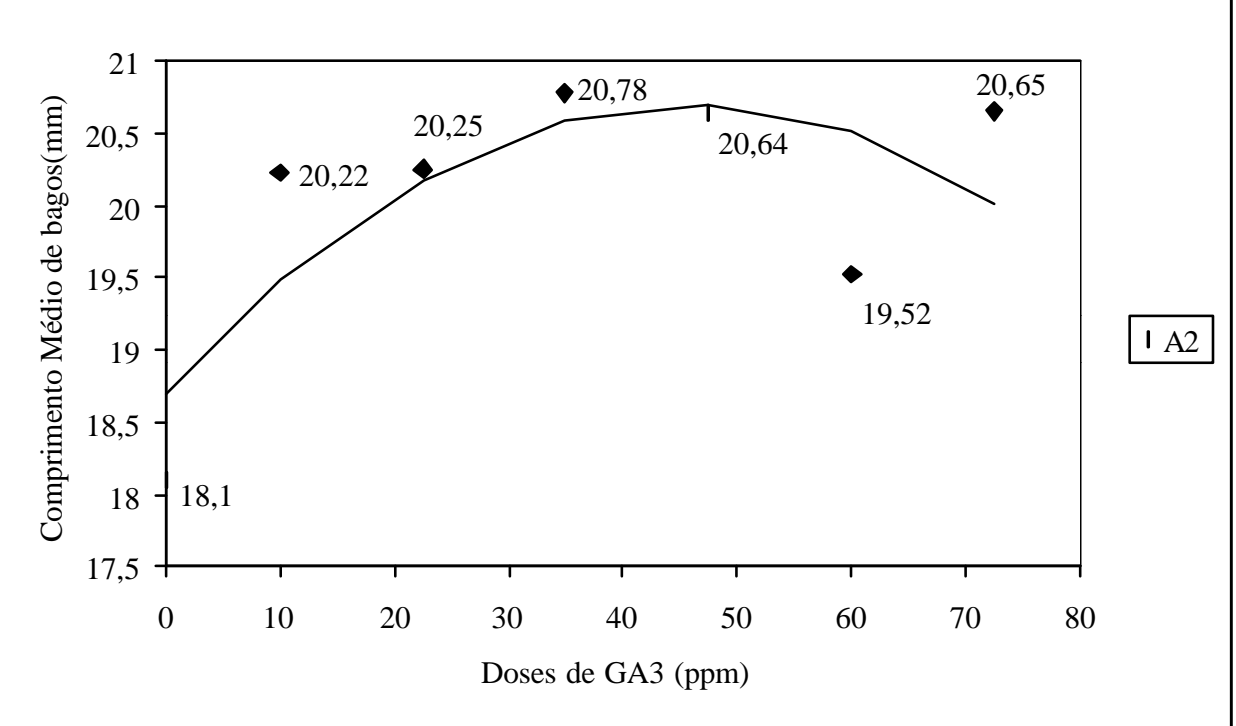

Figura 10 - Efeito da aplicação de diferentes doses de ácido giberélico, realizada juntamente com a prática do anelamento de ramos, sobre o comprimento médio dos bagos da cultivar Niagara Rosada, durante o primeiro ciclo vegetativo de 1999.

Tabela 8. Aplicação do teste de Tukey e de regressão polinomial para a largura média de bagos da cultivar Niagara Rosada durante o primeiro ciclo vegetativo de 1999.

\begin{tabular}{llc}
\hline Causas da Variação & \multicolumn{2}{c}{ Teste de Tukey para as médias de anelamento dentro das doses de } \\
& & GA3 \\
\hline Doses de GA3 & Sem Anelamento (A1) & Com Anelamento (A2) \\
Oppm & $16,69 \mathrm{aA}^{(1)}$ & $16,53 \mathrm{aA}$ \\
$\mathbf{1 0 , 0 p p m}$ & $17,03 \mathrm{bB}$ & $18,24 \mathrm{aA}$ \\
$\mathbf{2 2 , 5 p p m}$ & $17,14 \mathrm{bB}$ & $17,85 \mathrm{aA}$ \\
$\mathbf{3 5 , 0 p p m}$ & $18,04 \mathrm{aA}$ & $18,22 \mathrm{aA}$ \\
$\mathbf{4 7 , 5 p p m}$ & $16,88 \mathrm{bB}$ & $18,33 \mathrm{aA}$ \\
$\mathbf{6 0 , 0 p p m}$ & $17,23 \mathrm{aA}$ & $16,99 \mathrm{aA}$ \\
$\mathbf{7 2 , 5 p p m}$ & $17,57 \mathrm{bB}$ & $18,33 \mathrm{aA}$ \\
& Regressão Polinomial para as doses de Ácido Giberélico dentro dos \\
& & níveis do fator anelamento \\
& Sem Anelamento(A1) & Com Anelamento (A2) \\
Efeito Linear & $8,78^{*}{ }^{(3)}$ & $12,27^{* *}{ }^{(4)}$ \\
Efeito Quadrático & $3,35 \mathrm{~ns}{ }^{(2)}$ & $17,50^{* *}$ \\
\hline
\end{tabular}

(1) Médias dentro de uma linha seguidas de uma mesma letra minúscula ou maiúscula não diferem significativamente ao nível de $5 \%$ e $1 \%$ de probabilidade, respectivamente.

(2) Não significativo ao nível de $5 \%$ de probabilidade.

${ }^{(3)}$ Significativo ao nível de $5 \%$ de probabilidade.

${ }^{(4)}$ Significativo ao nível de $1 \%$ de probabilidade. 
O mesmo resultado observado para o comprimento médio dos bagos pode-se observar com relação à largura média dos bagos, ou seja, as doses de 10; 22,5; 47,5 e 72,5ppm de ácido giberélico sendo aplicadas conjuntamente com a técnica do anelamento de ramos, originaram bagos mais largos significativamente do que aqueles que receberam apenas ácido giberélico (Tabela 8).

Quando o ácido giberélico foi aplicado isoladamente, a maior largura foi obtida com a dose de 35ppm $(18,04 \mathrm{~mm})$, cujo incremento, com relação ao tratamento-controle, foi de $8,07 \%$ (Figura 11). Também nota-se uma tendência de aumento na largura média dos bagos com o aumento das doses do regular vegetal.

Já, quando juntamente com o regulador vegetal realizourse a técnica do anelamento de ramos, a melhor dose foi a de 47,5ppm, a qual gerou um incremento de 10,89\% na largura média dos bagos com relação ao tratamento-controle (Figura 12).

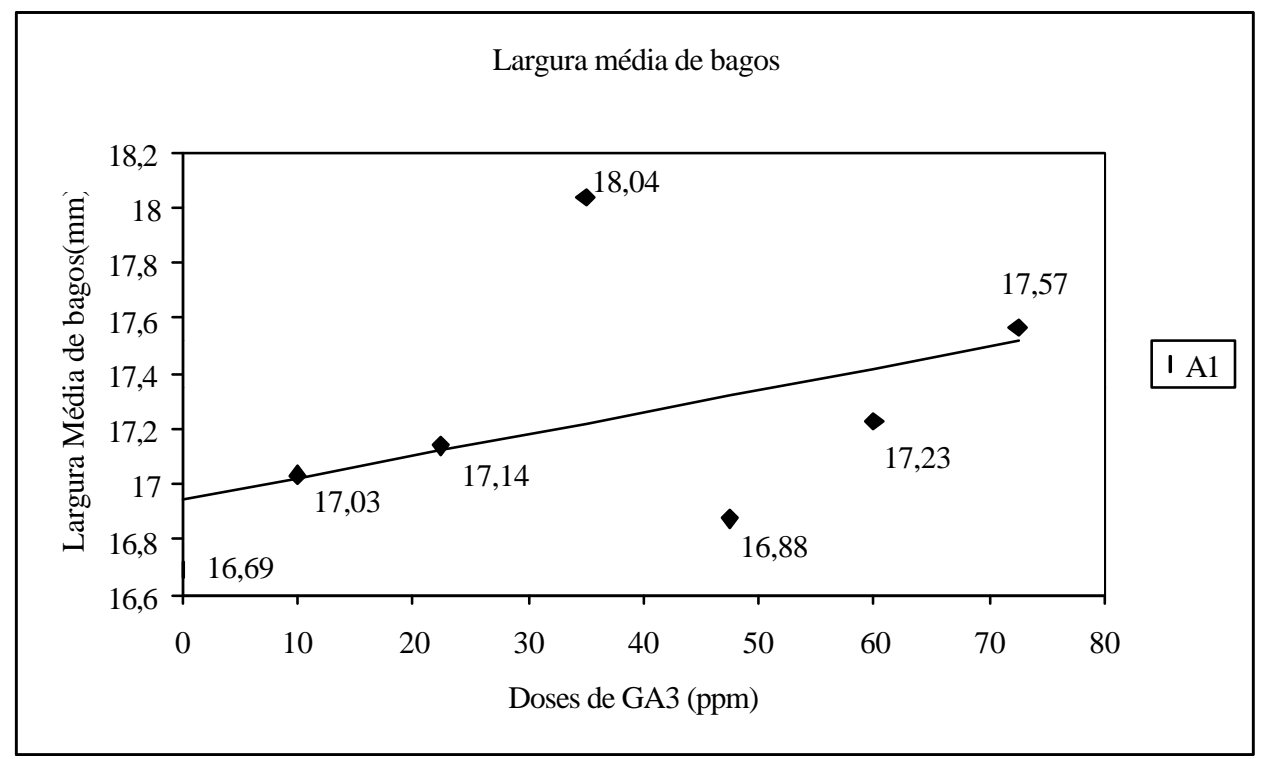

Figura 11 - Efeito da aplicação de diferentes doses de ácido giberélico, realizada isoladamente (sem a prática do anelamento de ramos), sobre a largura média dos bagos da cultivar Niagara Rosada, durante o primeiro ciclo vegetativo de 1999. 


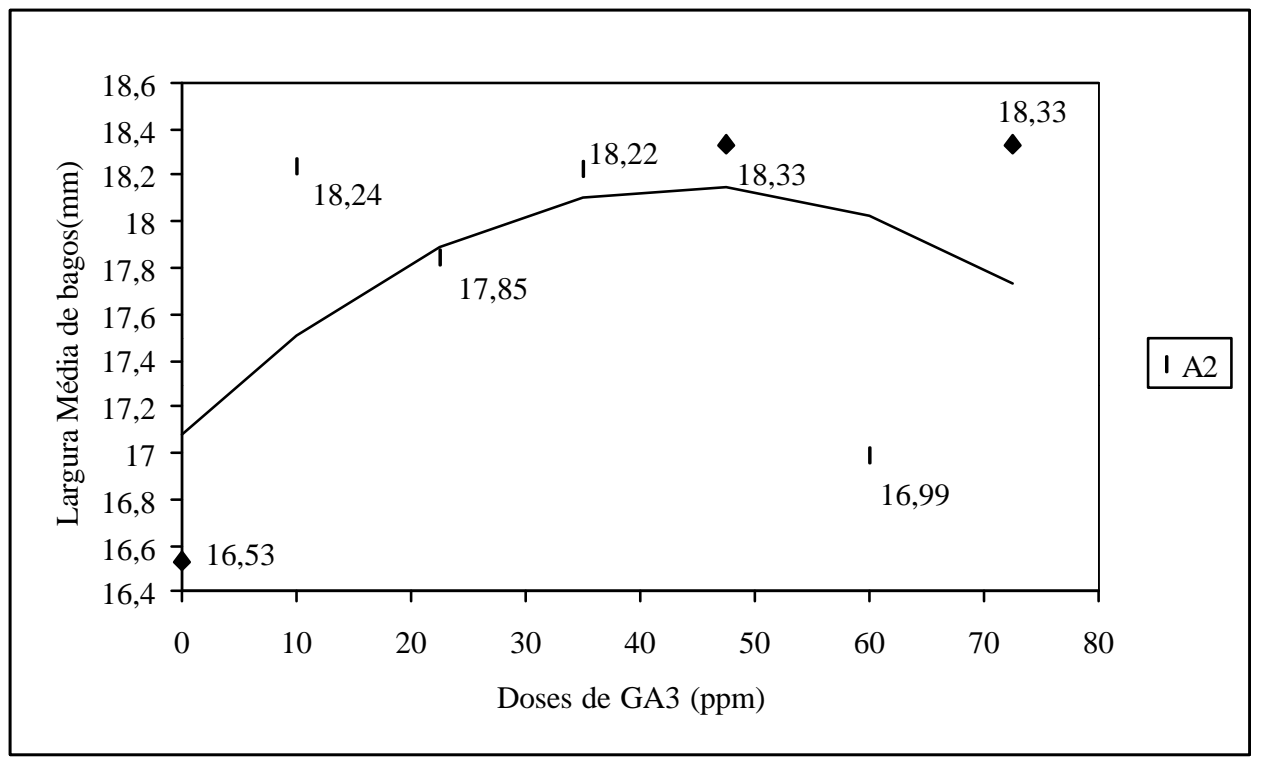

Figura 12 - Efeito da aplicação de diferentes doses de ácido giberélico, realizada juntamente com a prática do anelamento de ramos, sobre a largura média dos bagos da cultivar Niagara Rosada, durante o primeiro ciclo vegetativo de 1999 .

Tabela 9. Aplicação do teste de Tukey e de regressão polinomial para a massa média de bagos da cultivar Niagara Rosada durante o primeiro ciclo vegetativo de 1999.

\begin{tabular}{|c|c|c|}
\hline$\overline{\text { Causas da Variação }}$ & \multicolumn{2}{|c|}{$\begin{array}{l}\text { Teste de Tukey para as médias de anelamento dentro das doses de } \\
\text { GA3 }\end{array}$} \\
\hline Doses de GA3 & Sem Anelamento (A1) & Com Anelamento (A2) \\
\hline 0 ppm & $3,49 \mathrm{aA}^{(1)}$ & 3,26 aA \\
\hline $10,0 p p m$ & $3,70 \mathrm{bB}$ & $4,17 \mathrm{aA}$ \\
\hline $22,5 \mathrm{ppm}$ & $3,68 \mathrm{bB}$ & $4,12 \mathrm{aA}$ \\
\hline 35,0ppm & $4,19 \mathrm{aA}$ & $4,41 \mathrm{aA}$ \\
\hline 47,5ppm & $3,59 \mathrm{bB}$ & $4,44 \mathrm{aA}$ \\
\hline $60,0 \mathrm{ppm}$ & $3,99 \mathrm{aA}$ & $3,75 \mathrm{aA}$ \\
\hline \multirow[t]{3}{*}{$72,5 \mathrm{pm}$} & $3,89 \mathrm{bB}$ & $4,37 \mathrm{aA}$ \\
\hline & \multicolumn{2}{|c|}{$\begin{array}{c}\text { Regressão Polinomial para as doses de Ácido Giberélico dentro dos } \\
\text { níveis do fator anelamento }\end{array}$} \\
\hline & Sem Anelamento(A1) & Com Anelamento (A2) \\
\hline Efeito Linear & $9,07 * *(3)$ & $21,55 * *$ \\
\hline Efeito Quadrático & $2,95 \mathrm{~ns}$ & $25,17 * *$ \\
\hline
\end{tabular}


Com relação à massa média dos bagos, também verificou-se que o anelamento de ramos potencializou a ação do ácido giberélico quando as doses de 10; 22,5; 47,5 e $72,5 \mathrm{ppm}$ foram aplicadas, aumentando significativamente a massa média dos bagos. Não houve qualquer efeito do anelamento quando as doses de 35 e $60 \mathrm{ppm}$ foram aplicadas.

Para esta característica quando o ácido giberélico foi aplicado isoladamente notase na Figura 13 uma tendência de aumento na massa média dos bagos nos tratamentos que receberam a aplicação do regulador vegetal, apresentando médias superiores ao tratamento-controle (0ppm), sendo que o maior valor foi obtido com a dose de 35ppm $(4,191 \mathrm{~g})$, o qual foi 20,47\% superior ao tratamento controle. Kasimatis et al. (1978) também obtiveram aumento na massa dos bagos da videira 'Thompson Seedless', aplicando ácido giberélico em pleno florescimento.

Quando juntamente com o regulador vegetal realizourse a técnica do anelamento de ramos, a melhor dose foi a de 47,5ppm (4,445g), quando a massa dos bagos foi $36,43 \%$ maior que a do tratamento-controle (0ppm) (Figura 14).

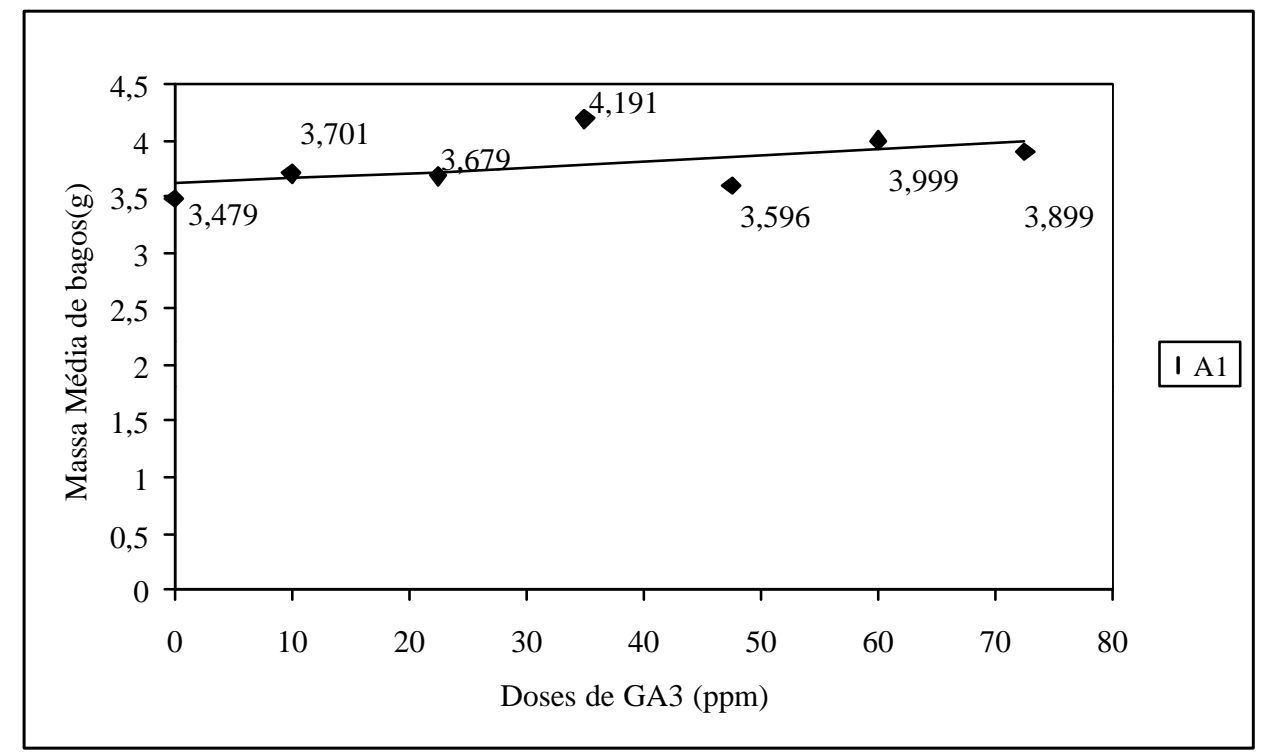

Figura 13 - Efeito da aplicação de diferentes doses de ácido giberélico, realizada isoladamente (sem a prática do anelamento de ramos), sobre a massa média dos bagos da cultivar Niagara Rosada, durante o primeiro ciclo vegetativo de 1999 . 


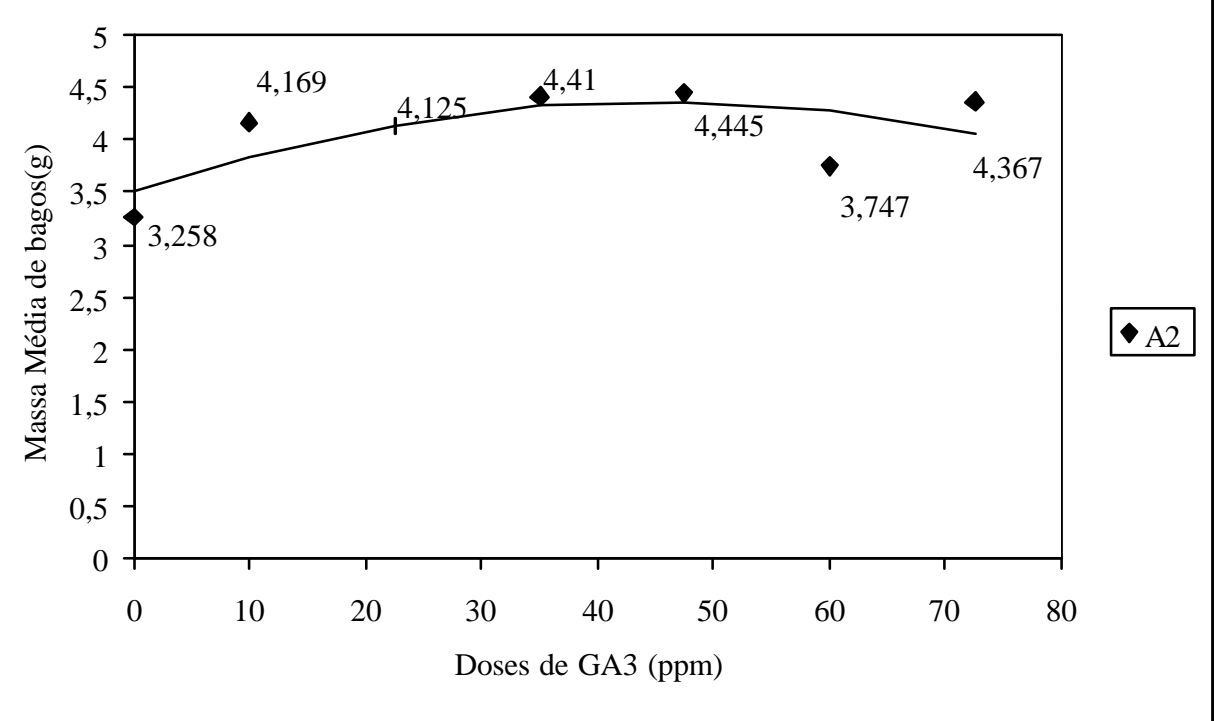

Figura 14 - Efeito da aplicação de diferentes doses de ácido giberélico, realizada conjuntamente com a prática do anelamento de ramos, sobre a massa média dos bagos da cultivar Niagara Rosada, durante o primeiro ciclo vegetativo de 1999.

Assim, avaliando os resultados obtidos para as características mensuradas nos cachos e bagos, nota-se que o aumento obtido no tamanho e massa dos cachos com a aplicação da dose de 35ppm de ácido giberélico, deveu-se ao aumento no tamanho e massa dos bagos e não a um aumento no número médio de bagos por cacho, pois este não foi afetado pelas diferentes doses do regulador vegetal em estudo.

A tabela 10 mostra que o anelamento de ramos realizado isoladamente (0ppm de ácido giberélico), não interferiu significativamente na acidez total titulável do mosto. Porém, nota-se que para as doses de 35 e 60ppm, a acidez titulável foi menor significativamente quando conjuntamente realizou-se o anelamento de ramos. Além disso, na Figura 15 nota-se uma tendência de aumento na acidez total titulável com o aumento das doses de ácido giberélico sendo aplicado isoladamente. Ao passo que, quando conjuntamente com a aplicação deste regulador vegetal realizourse o anelamento de ramos, a tendência foi de diminuir a acidez total titulável com o aumento da dose (Figura 16). 
Tabela 10. Aplicação do teste de Tukey e de regressão polinomial para a acidez titulável da cultivar Niagara Rosada durante o primeiro ciclo vegetativo de 1999.

\begin{tabular}{llc}
\hline Causas da Variação & \multicolumn{2}{c}{ Teste de Tukey para as médias de anelamento dentro das doses de } \\
& & GA3 \\
\hline Doses de GA3 & Sem Anelamento (A1) & Com Anelamento (A2) \\
Oppm & $0,97 \mathrm{aA}{ }^{(1)}$ & $1,01 \mathrm{aA}$ \\
$\mathbf{1 0 , 0 p p m}$ & $0,99 \mathrm{bB}$ & $1,16 \mathrm{aA}$ \\
$\mathbf{2 2 , 5 p p m}$ & $1,05 \mathrm{aA}$ & $1,02 \mathrm{aA}$ \\
$\mathbf{3 5 , 0 p p m}$ & $1,16 \mathrm{aA}$ & $1,05 \mathrm{bA}$ \\
$\mathbf{4 7 , 5 p p m}$ & $0,96 \mathrm{aA}$ & $0,99 \mathrm{aA}$ \\
$\mathbf{6 0 , 0 p p m}$ & $1,14 \mathrm{aA}$ & $0,91 \mathrm{bB}$ \\
$\mathbf{7 2 , 5 p p m}$ & $1,01 \mathrm{aA}$ & $1,01 \mathrm{aA}$ \\
& Regressão Polinomial para as doses de Ácido Giberélico dentro dos \\
& & níveis do fator anelamento \\
& Sem Anelamento(A1) Com Anelamento (A2) & $12,03^{*}$ \\
Efeito Linear & $4,33^{*}{ }^{(3)}$ & $0,04 \mathrm{~ns}$ \\
Efeito Quadrático & $9,97^{* *}{ }^{(4)}$ &
\end{tabular}

(1) Médias dentro de uma linha seguidas de uma mesma letra minúscula ou maiúscula não diferem significativamente ao nível de $5 \%$ e $1 \%$ de probabilidade, respectivamente.

${ }^{(2)}$ Não significativo ao nível de $5 \%$ de probabilidade.

${ }^{(3)}$ Significativo ao nível de $5 \%$ de probabilidade.

${ }^{(4)}$ Significativo ao nível de $1 \%$ de probabilidade.

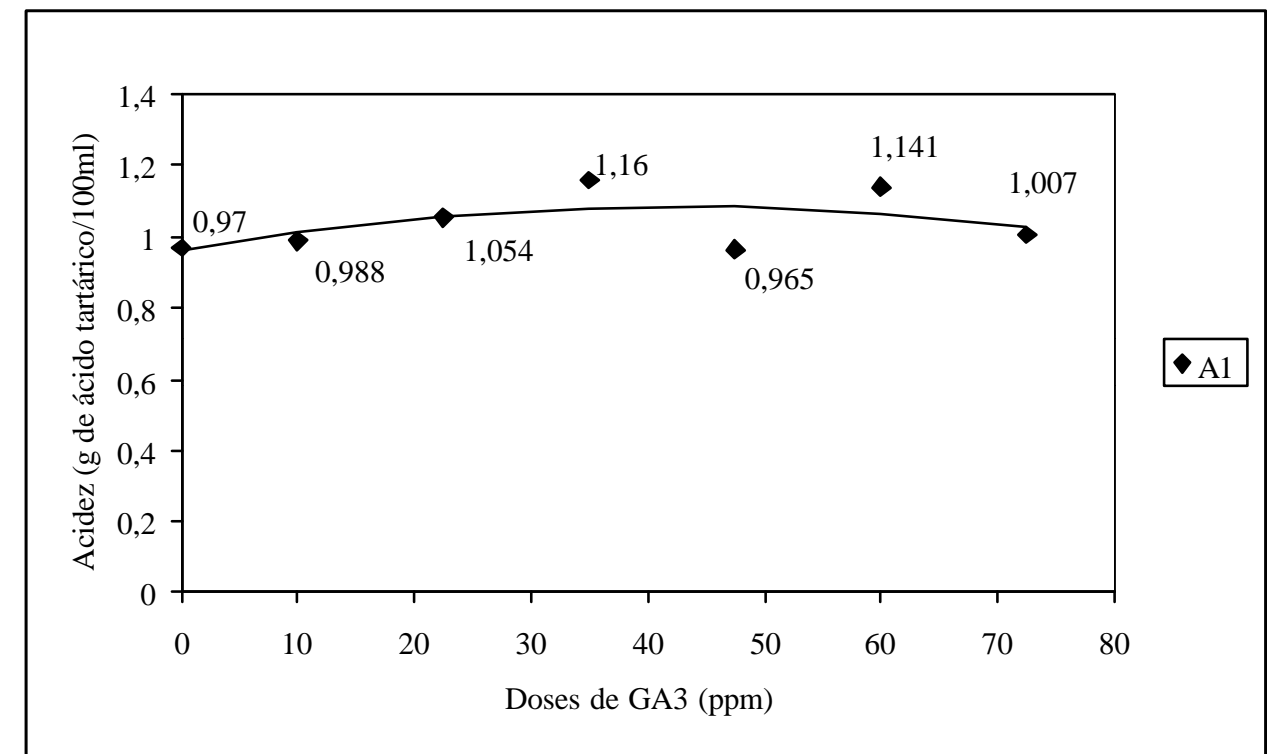

Figura 15 - Efeito da aplicação de diferentes doses de ácido giberélico, realizada isoladamente (sem a prática do anelamento de ramos), sobre a acidez titulável da cultivar Niagara Rosada, durante o primeiro ciclo vegetativo de 1999. 


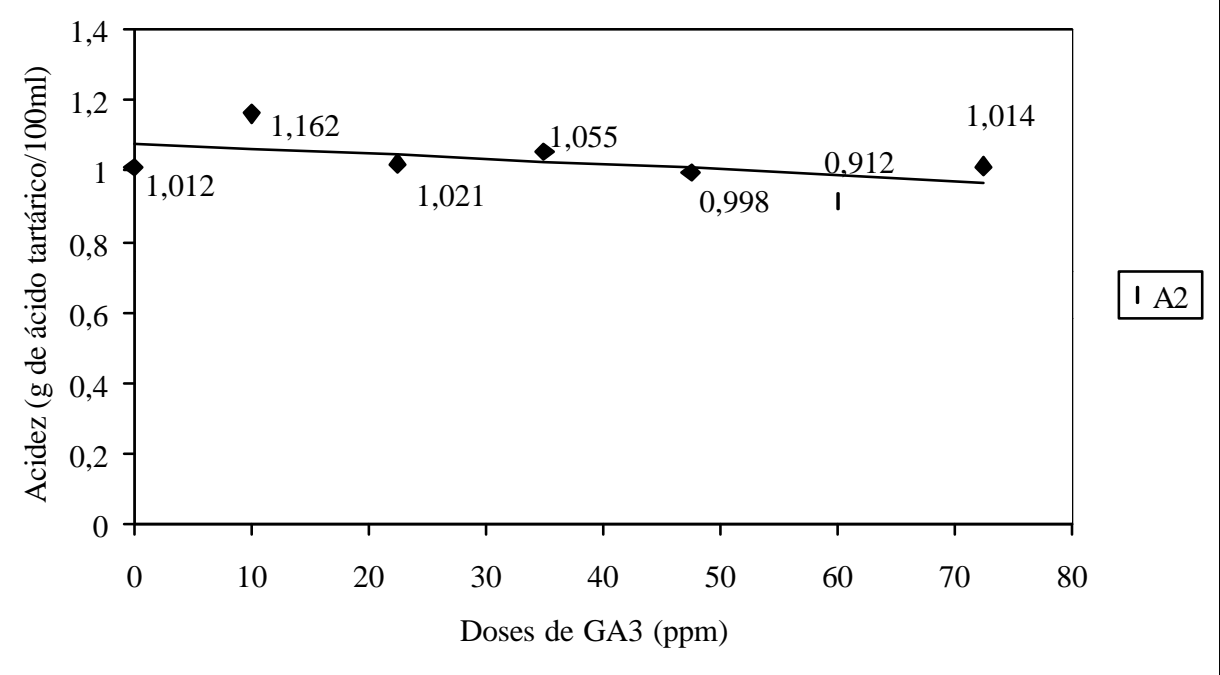

Figura 16 - Efeito da aplicação de diferentes doses de ácido giberélico, realizada juntamente com a prática do anelamento de ramos, sobre a acidez titulável da cultivar Niagara Rosada, durante o primeiro ciclo vegetativo de 1999.

Assim como observado por Gonzalo et al. (1984), trabalhando com cultivares com sementes, o anelamento de ramos realizado isoladamente diminuiu o teor de sólidos solúveis (Tabela 11), dados estes discordantes de muitos outros trabalhos já publicados. O que se pode verificar neste trabalho (Tabela 11) é que o anelamento de ramos aumentou significativamente o teor de sólidos solúveis quando realizou-se também a aplicação de 35 e 47,5 ppm de ácido giberélico.

Já, com relação ao efeito de doses de ácido giberélico sobre o teor de sólidos solúveis totais observa-se na Figura 17 valores decrescentes com o aumento das doses até 47,5ppm de ácido giberélico tendo sido aplicado isoladamente. Porém, quando conjuntamente com o ácido giberélico realizourse o anelamento de ramos, houve uma tendência de aumento nesta característica até a dose de 47,5ppm (Figura 18). 
Tabela 11. Aplicação do teste de Tukey e de regressão polinomial para o teor de sólidos solúveis da cultivar Niagara Rosada durante o primeiro ciclo vegetativo de 1999.

\begin{tabular}{llc}
\hline Causas da Variação & \multicolumn{2}{c}{ Teste de Tukey para as médias de anelamento dentro das doses de } \\
& & GA3 \\
\hline Doses de GA3 & Sem Anelamento (A1) & Com Anelamento (A2) \\
$\mathbf{0} \mathbf{~ p p m}$ & $16,33 \mathrm{aA}$ & $14,56 \mathrm{bB}$ \\
$\mathbf{1 0 , 0} \mathbf{~ p p m}$ & $16,10 \mathrm{aA}$ & $15,06 \mathrm{bB}$ \\
$\mathbf{2 2 , 5} \mathbf{~ p p m}$ & $15,64 \mathrm{aA}$ & $15,99 \mathrm{aA}$ \\
$\mathbf{3 5 , 0} \mathbf{~ p p m}$ & $14,87 \mathrm{bA}$ & $15,84 \mathrm{aA}$ \\
$\mathbf{4 7 , 5} \mathbf{~ p p m}$ & $15,19 \mathrm{bA}$ & $16,03 \mathrm{aA}$ \\
$\mathbf{6 0 , 0} \mathbf{~ p p m}$ & $14,39 \mathrm{aA}$ & $14,29 \mathrm{aA}$ \\
$\mathbf{7 2 , 5} \mathbf{~ p p m}$ & $15,53 \mathrm{aA}$ & $15,37 \mathrm{aA}$ \\
& Regressão Polinomial para as doses de Ácido Giberélico dentro dos \\
& & níveis do fator anelamento \\
& & Com Anelamento (A2) \\
Efeito Linear & Sem Anelamento(A1) & $0,303 \mathrm{~ns}{ }^{(2)}$ \\
Efeito Quadrático & $9,75^{* *}$ & $15,32^{* *}$ \\
\hline
\end{tabular}

${ }^{(1)}$ Médias dentro de uma linha seguidas de uma mesma letra minúscula ou maiúscula não diferem significativamente ao nível de $5 \%$ e $1 \%$ de probabilidade, respectivamente.

${ }^{(2)}$ Não significativo ao nível de $5 \%$ de probabilidade.

${ }^{(3)}$ Significativo ao nível de $1 \%$ de probabilidade.

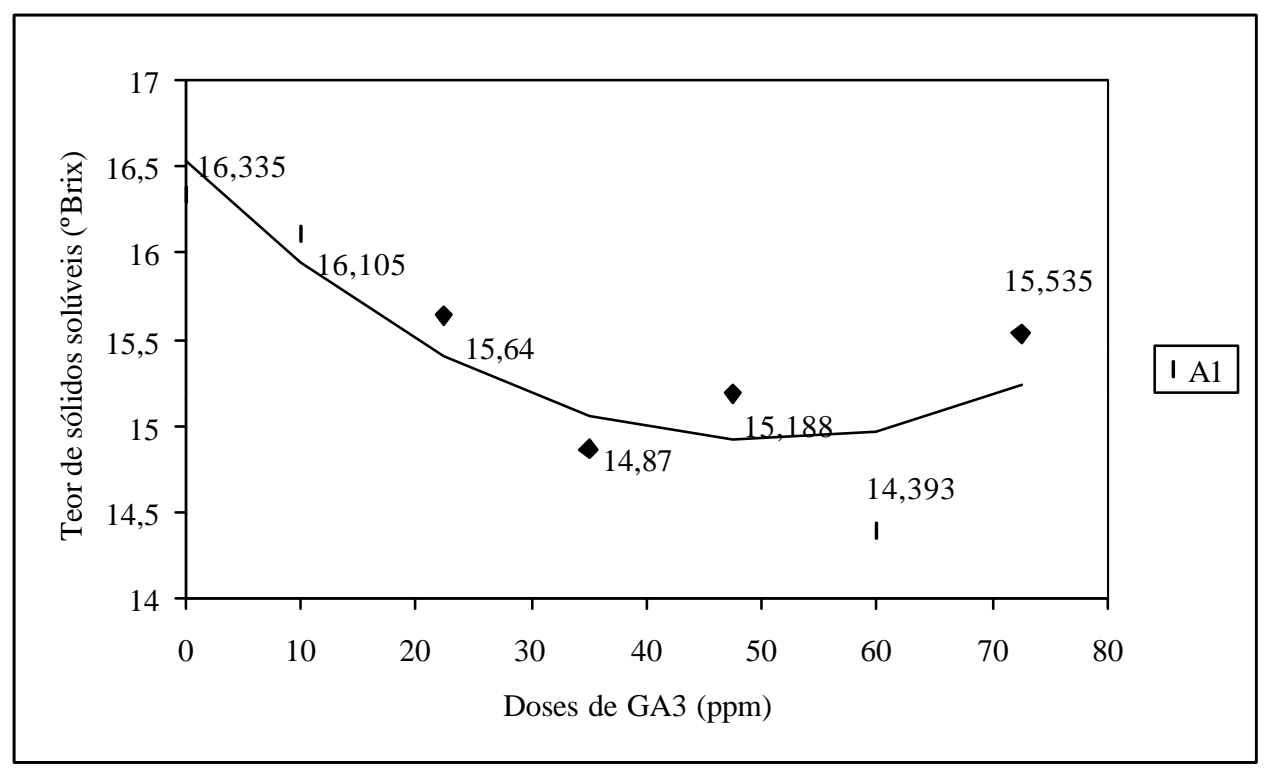

Figura 17 - Efeito da aplicação de diferentes doses de ácido giberélico, realizada isoladamente (sem a prática do anelamento de ramos), sobre o teor de sólidos solúveis da cultivar Niagara Rosada, durante o primeiro ciclo vegetativo de 1999. 


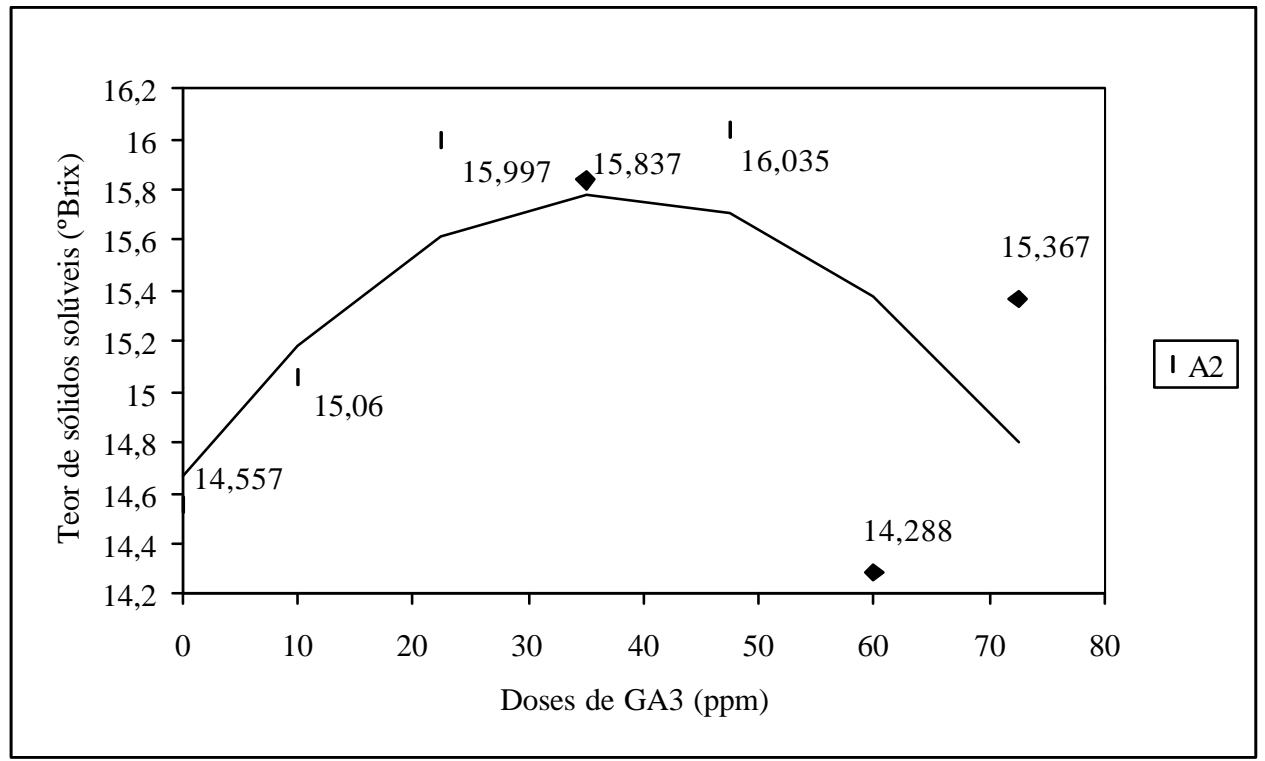

Figura 18 - Efeito da aplicação de diferentes doses de ácido giberélico, realizada juntamente com a prática do anelamento de ramos, sobre teor de sólidos solúveis da cultivar Niagara Rosada, durante o primeiro ciclo vegetativo de 1999.

Isso sugere que, o atraso na maturação provocado pelo ácido giberélico pode ser minimizado realizando-se conjuntamente o anelamento de ramos.

De uma maneira geral, verificourse que a aplicação de 35ppm de ácido giberélico isoladamente originou maiores massas de cachos, engaços e bagos, maiores comprimentos de cachos e de bagos e maior largura de bagos. Já, o anelamento de ramos não interferiu nas características mensuradas nos cachos, havendo efeito significativo desta técnica apenas sobre as características mensuradas nos bagos e sobre o diâmetro do pedicelo quando a dose de 47,5ppm de ácido giberélico foi aplicada. Assim, visando a redução de custos, o produtor pode optar pela aplicação isolada do ácido giberélico. Tais resultados diferem daqueles obtidos por Pommer et al (1995), que constataram efeito superior do anelamento mais a aplicação do ácido giberélico sobre a massa, o comprimento, a largura dos cachos; número, massa, comprimento e largura de bagos, em relação ao anelamento ou a aplicação do regulador vegetal feitos isoladamente. 


\subsection{2 'Niagara Rosada' - Segundo Ciclo Vegetativo de 1999}

O delineamento experimental foi em blocos ao acaso com 18 tratamentos e 5 repetições no esquema fatorial 2x9. Houve a combinação dos dois seguintes fatores: 1) com anelamento ou sem anelamento e 2) doses de ácido giberélico (Quadro 3).

\begin{tabular}{|l|l|}
\hline \multicolumn{2}{|l|}{ Anelamento } \\
\hline Anel 1 & Sem anelamento \\
Anel 2 & Com anelamento \\
\hline \multicolumn{2}{|l|}{ Doses } \\
\hline Dose 1 & Oppm \\
Dose 2 & $10 \mathrm{ppm}$ \\
Dose 3 & $22,5 \mathrm{ppm}$ \\
Dose 4 & $35 \mathrm{ppm}$ \\
Dose 5 & $47,5 \mathrm{ppm}$ \\
Dose 6 & $60 \mathrm{ppm}$ \\
Dose 7 & $72,5 \mathrm{ppm}$ \\
Dose 8 & 85ppm \\
Dose 9 & $97,5 \mathrm{ppm}$ \\
\hline
\end{tabular}

Quadro 3 - Conjunto dos fatores que compõem o fatorial.

$\mathrm{Na}$ Tabela 12 encontram-se os resultados da análise estatística com aplicação do Teste "F" para as características avaliadas nos cachos da cultivar Niagara Rosada durante o segundo ciclo vegetativo de 1999 .

Tabela 12. Aplicação do Teste "F" para as características mensuradas nos cachos da cultivar Niagara Rosada durante o segundo ciclo vegetativo de 1999.

\begin{tabular}{lllll}
\hline $\begin{array}{l}\text { Causas da } \\
\text { Variação }\end{array}$ & $\begin{array}{l}\text { Comprimento de } \\
\text { cachos }(\mathrm{cm})\end{array}$ & $\begin{array}{l}\text { Largura de } \\
\text { cachos }(\mathrm{cm})\end{array}$ & $\begin{array}{l}\text { Massa de cachos } \\
(\mathrm{g}) \\
\text { Teste “F” }\end{array}$ & $\begin{array}{l}\text { Número de } \\
\text { bagos/cacho }\end{array}$ \\
\hline Anelamento & $0,738 \mathrm{~ns}{ }^{(1)}$ & $2,704 \mathrm{~ns}$ & $2,172 \mathrm{~ns}$ & $0,852 \mathrm{~ns}$ \\
Doses de GA3 & $5,102^{* *(3)}$ & $3,349^{* *}$ & $8,893^{* *}$ & $4,909^{* *}$ \\
Interação & $1,966 \mathrm{~ns}$ & $2,504^{*(2)}$ & $3,152^{* *}$ & $2,199^{*}$ \\
AnelxGA3 & & & \\
${ }^{(1)}$ Não significativo ao nível de 5\% de probabilidade. & & \\
${ }^{(2)}$ Significativo ao nível de 5\% de probabilidade. & & \\
${ }^{(3)}$ Significativo ao nível de 1\% de probabilidade.
\end{tabular}


Como pode-se observar na Tabela 12, para as características mensuradas nos cachos, a interação entre os fatores não foi significativa apenas para o comprimento médio dos cachos, sendo este afetado apenas por doses de ácido giberélico.

Tabela 13. Aplicação de regressão polinomial para o comprimento médio dos cachos da cultivar Niagara Rosada durante o segundo ciclo vegetativo de 1999.

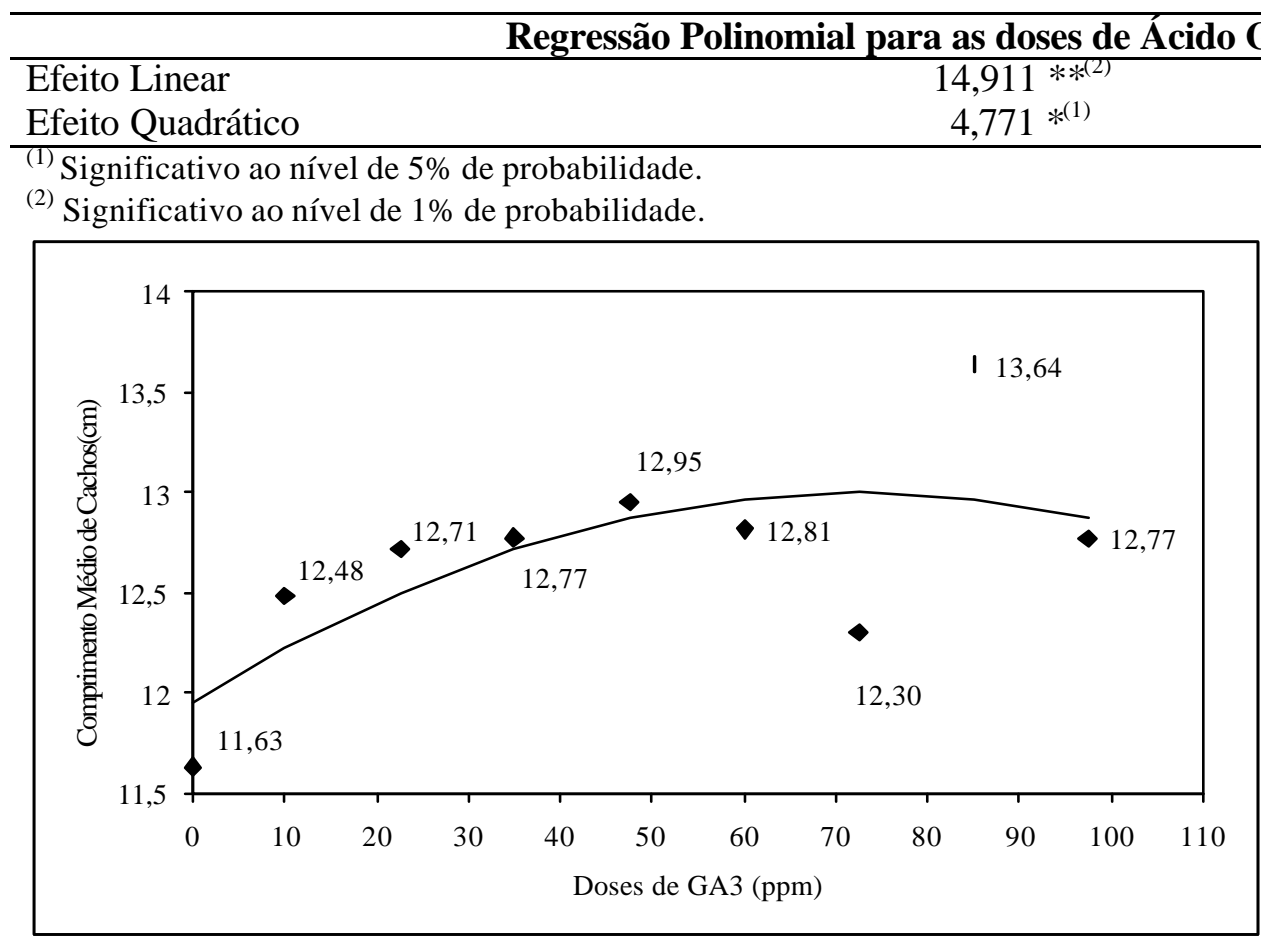

Figura 19 - Efeito de diferentes doses de ácido giberélico, sobre o comprimento médio dos cachos da cultivar Niagara Rosada, durante o segundo ciclo vegetativo de 1999.

Nota-se através de regressão polinomial (Figura 19), que todos os tratamentos que receberam ácido giberélico apresentaram comprimentos médios de cachos superiores ao tratamento-controle.

O maior comprimento médio de cacho foi de $13,64 \mathrm{~cm}$ obtido com a dose de 85ppm, seguido de $12,95 \mathrm{~cm}$ com a dose de 47,5ppm, sendo $17,28 \%$ e 11,38\% superiores ao tratamento-controle, respectivamente. 
Tabela 14. Aplicação do teste de Tukey e de regressão polinomial para a largura dos cachos da cultivar Niagara Rosada durante o segundo ciclo vegetativo de 1999.

\begin{tabular}{llc}
\hline Causas da Variação & \multicolumn{2}{c}{ Teste de Tukey para as médias de anelamento dentro das doses de } \\
& & GA3 \\
\hline Doses de GA3 & Sem Anelamento (A1) & Com Anelamento (A2) \\
Oppm & $6,930 \mathrm{aA}^{(1)}$ & $6,520 \mathrm{aA}$ \\
$\mathbf{1 0 , 0 p p m}$ & $7,535 \mathrm{aA}$ & $6,885 \mathrm{aA}$ \\
$\mathbf{2 2 , 5 p p m}$ & $7,365 \mathrm{aA}$ & $7,740 \mathrm{aA}$ \\
$\mathbf{3 5 , 0 p p m}$ & $7,115 \mathrm{bB}$ & $8,355 \mathrm{aA}$ \\
$\mathbf{4 7 , 5 p p m}$ & $7,657 \mathrm{aA}$ & $7,527 \mathrm{aA}$ \\
$\mathbf{6 0 , 0 p p m}$ & $7,125 \mathrm{bB}$ & $8,267 \mathrm{aA}$ \\
$\mathbf{7 2 , 5 p p m}$ & $7,195 \mathrm{aA}$ & $7,788 \mathrm{aA}$ \\
$\mathbf{8 5 , 0 p p m}$ & $8,253 \mathrm{aA}$ & $7,985 \mathrm{aA}$ \\
$\mathbf{9 7 , 5 p p m}$ & $7,577 \mathrm{aA}$ & $7,767 \mathrm{aA}$ \\
& Regressão Polinomial para as doses de Ácido Giberélico dentro dos \\
& & níveis do fator anelamento \\
& Sem Anelamento(A1) & Com Anelamento (A2) \\
Efeito Linear & $3,577 \mathrm{~ns}(2)$ & $12,514 * * 3)$ \\
Efeito Quadrático & $0,137 \mathrm{~ns}$ & $11,672 * *$ \\
\hline
\end{tabular}

(1) Médias dentro de uma linha seguidas de uma mesma letra minúscula ou maiúscula não diferem significativamente ao nível de $5 \%$ e $1 \%$ de probabilidade, respectivamente.

${ }^{(2)}$ Não significativo ao nível de $5 \%$ de probabilidade.

${ }^{(3)}$ Significativo ao nível de $1 \%$ de probabilidade.

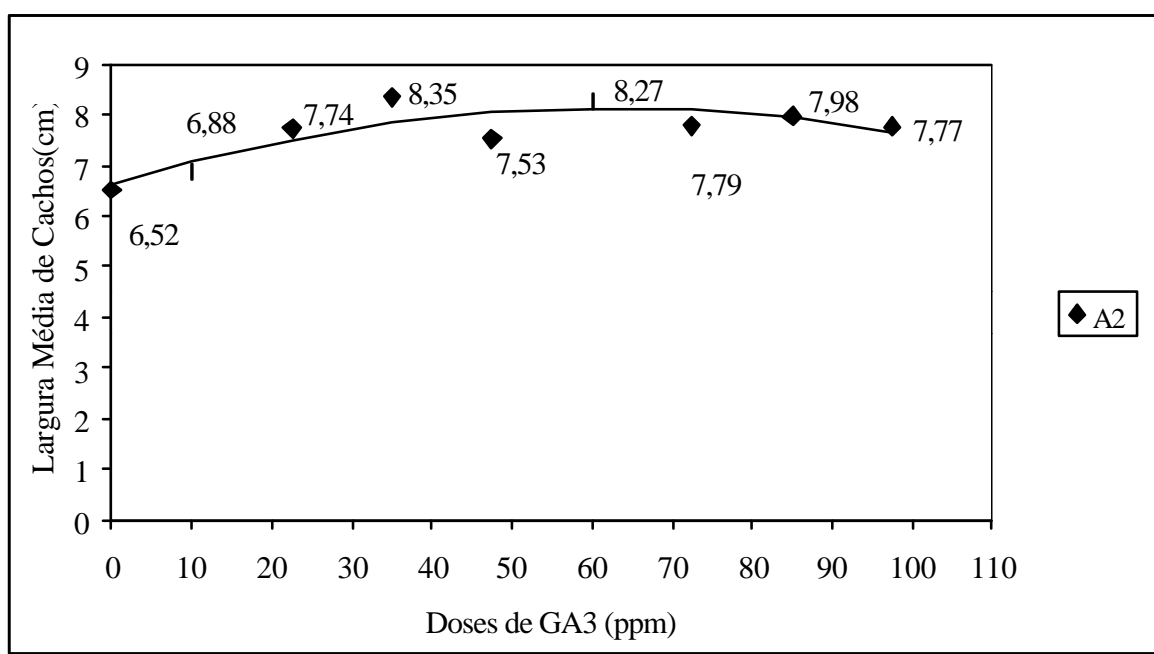

Figura 20 - Efeito da aplicação de diferentes doses de ácido giberélico, realizada juntamente com a prática do anelamento de ramos, sobre a largura média dos cachos da cultivar Niagara Rosada, durante o segundo ciclo vegetativo de 1999. 
Tabela 15. Aplicação do teste de Tukey e de regressão polinomial para a massa média dos cachos da cultivar Niagara Rosada durante o segundo ciclo vegetativo de 1999.

\begin{tabular}{llc}
\hline Causas da Variação & \multicolumn{2}{c}{ Teste de Tukey para as médias de anelamento dentro das doses de } \\
& & GA3 \\
\hline Doses de GA3 & Sem Anelamento (A1) & Com Anelamento (A2) \\
Oppm & $192,305 \mathrm{aA}^{(1)}$ & $172,601 \mathrm{aA}$ \\
$\mathbf{1 0 , 0 p p m}$ & $219,500 \mathrm{aA}$ & $195,445 \mathrm{aA}$ \\
$\mathbf{2 2 , 5 p p m}$ & $217,730 \mathrm{aA}$ & $206,472 \mathrm{aA}$ \\
$\mathbf{3 5 , 0 p p m}$ & $224,795 \mathrm{bA}$ & $265,523 \mathrm{aA}$ \\
$\mathbf{4 7 , 5 p p m}$ & $231,947 \mathrm{aA}$ & $221,825 \mathrm{aA}$ \\
$\mathbf{6 0 0 , 0 p p m}$ & $204,505 \mathrm{bB}$ & $261,977 \mathrm{aA}$ \\
$\mathbf{7 2 , 5 p p m}$ & $191,335 \mathrm{aA}$ & $202,036 \mathrm{aA}$ \\
$\mathbf{8 5 , 0 p p m}$ & $256,043 \mathrm{aA}$ & $257,920 \mathrm{aA}$ \\
$\mathbf{9 7 , 5 p p m}$ & $216,555 \mathrm{aA}$ & $240,950 \mathrm{aA}$ \\
& Regressão Polinomial para as doses de Ácido Giberélico dentro dos \\
& & níveis do fator anelamento \\
& Sem Anelamento(A1) & Com Anelame nto (A2) \\
Efeito Linear & $2,255 \mathrm{~ns}{ }^{(2)}$ & $26,163 * * 3)$ \\
Efeito Quadrático & $0,428 \mathrm{~ns}$ & $10,827 * *$ \\
\hline
\end{tabular}

${ }^{(1)}$ Médias dentro de uma linha seguidas de uma mesma letra minúscula ou maiúscula não diferem significativamente ao nível de $5 \%$ e $1 \%$ de probabilidade, respectivamente.

${ }^{(2)}$ Não significativo ao nível de $5 \%$ de probabilidade.

${ }^{(3)}$ Significativo ao nível de $1 \%$ de probabilidade.

Nota-se efeito significativo de doses de ácido giberélico sobre a largura e massa média dos cachos quando aplicadas conjuntamente com o anelamento de ramos (Tabelas 14 e 15).

As maiores larguras médias de cachos foram constatadas com as doses de 35 ou 60ppm aplicadas conjuntamente com a prática do anelamento de ramos, sendo estas $28,07 \%$ e $26,8 \%$ superiores ao tratamento-controle. (Figura 20).

As maiores massas também foram obtidas realizando-se a aplicação de 35 ou 60ppm de ácido giberélico conjuntamente com o anelamento, cujos incrementos foram de $53,83 \%$ e $51,8 \%$ sobre a massa média dos cachos do tratamento-controle (Figura 21). 


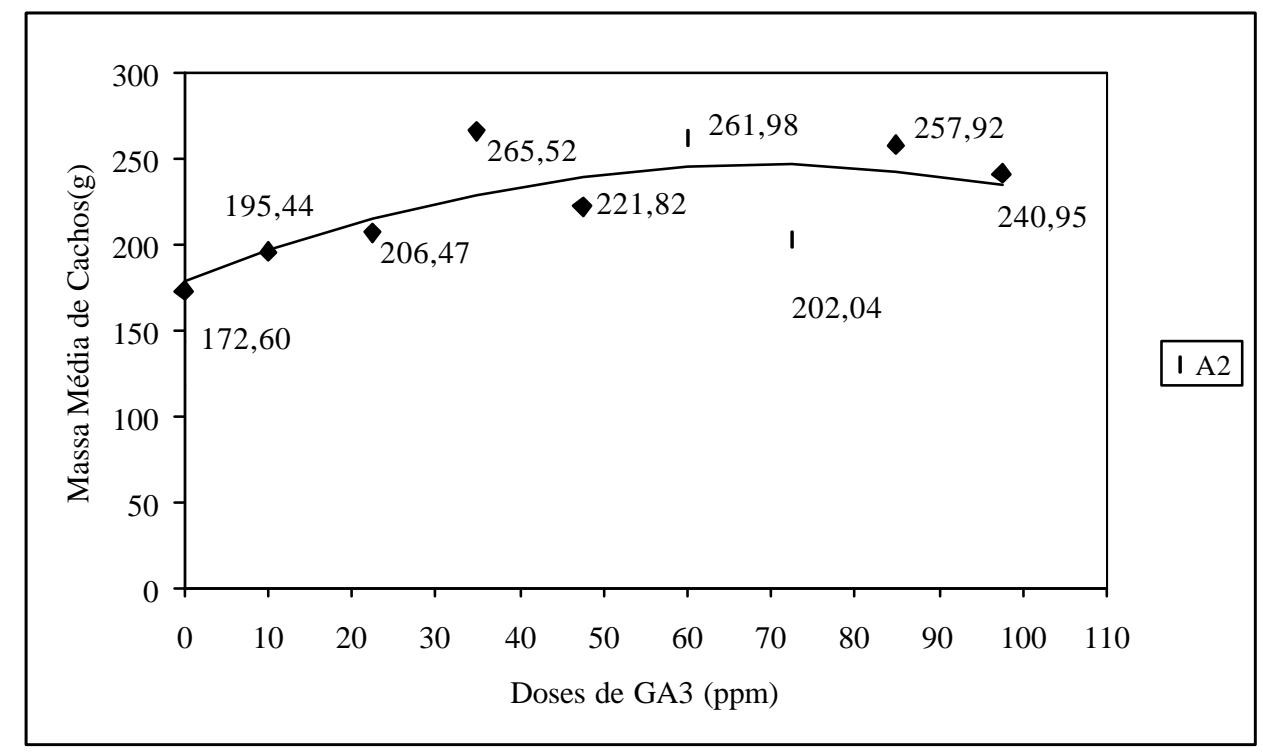

Figura 21 - Efeito da aplicação de diferentes doses de ácido giberélico, realizada conjuntamente com a prática do anelamento de ramos, sobre a massa média dos cachos da cultivar Niagara Rosada, durante o segundo ciclo vegetativo de 1999.

No primeiro experimento realizado com esta mesma cultivar no período de março a maio de 1999 (primeiro ciclo vegetativo), notou-se que não houve influência do anelamento de ramos sobre a massa, o comprimento e a largura dos cachos. Além disso, a melhor dose foi a de 35ppm para o comprimento e a massa dos cachos, e a de 47,5ppm para a largura dos cachos.

Já, neste experimento realizado no período de novembro de 1999 à janeiro de 2000, houve efeito do anelamento sendo realizado conjuntamente com a aplicação de ácido giberélico sobre a largura e a massa média dos cachos, sendo que a dose de 35ppm foi a que proporcionou maiores incrementos. Os cachos mais compridos foram obtidos com a aplicação isolada de ácido giberélico nas doses de 47,5 e 85ppm.

Tais variações de um experimento para outro podem ter ocorrido devido à interferência de fatores climáticos, visto que os dois experimentos foram realizados no mesmo vinhedo. 
Tabela 16. Aplicação do teste de Tukey e de regressão polinomial para o número médio de bagos por cacho da cultivar Niagara Rosada durante o segundo ciclo vegetativo de 1999.

\begin{tabular}{llc}
\hline Causas da Variação & \multicolumn{2}{c}{ Teste de Tukey para as médias de anelamento dentro das doses de } \\
GA3
\end{tabular}

Não houve efeito significativo de doses de ácido giberélico quando este foi aplicado sozinho ou em conjunto com o anelamento de ramos (Tabela 16). Também, não se observou efeito do anelamento de ramos quando realizado isoladamente (dose 0ppm). $\mathrm{Na}$ Tabela 16, verifica-se que quando a dose de 35ppm foi aplicada conjuntamente com o anelamento de ramos, o número médio de bagos por cacho foi significativamente maior, em comparação com a mesma dose sendo aplicada isoladamente. Porém, o contrário observou-se para a dose de 10ppm.

A interação entre os fatores não foi significativa para o comprimento, a largura e a massa dos engaços, havendo efeito apenas da aplicação de ácido giberélico sobre tais características (Tabela 17). 
Tabela 17. Aplicação do Teste "F" para as características mensuradas nos engaços da cultivar Niagara Rosada durante o segundo ciclo vegetativo de 1999.

\begin{tabular}{lllll}
\hline $\begin{array}{l}\text { Causas da } \\
\text { Variação }\end{array}$ & $\begin{array}{l}\text { Comprimento dos } \\
\text { engaços }(\mathrm{cm})\end{array}$ & $\begin{array}{l}\text { Largura dos } \\
\text { engaços }(\mathrm{cm})\end{array}$ & $\begin{array}{l}\text { Massa dos } \\
\text { engaços }(\mathrm{g})\end{array}$ & $\begin{array}{l}\text { Diâmetro dos } \\
\text { pedicelos }(\mathrm{mm})\end{array}$ \\
Anelamento & $0,195 \mathrm{~ns}{ }^{(1)}$ & $0,001 \mathrm{~ns}$ & $2,076 \mathrm{~ns}$ & $7,486 * *$ \\
Doses de GA30 & $4,974 * *^{(3)}$ & $2,619 *(2)$ & $4,407 * *$ & $5,979 * *$ \\
Interação & $1,874 \mathrm{~ns}$ & $2,039 \mathrm{~ns}$ & $1,979 \mathrm{~ns}$ & $4,499 * *$ \\
AnelxGA3 & & & \\
${ }^{(1)}$ Não significativo ao nível de 5\% de probabilidade. \\
${ }^{(2)}$ Significativo ao nível de 5\% de probabilidade. \\
${ }^{(3)}$ Significativo ao nível de 1\% de probabilidade.
\end{tabular}

Tabela 18. Aplicação de regressão polinomial para o comprimento médio, a largura média e a massa média dos engaços da cultivar Niagara Rosada durante o segundo ciclo vegetativo de 1999.

\begin{tabular}{|c|c|c|c|}
\hline & \multicolumn{3}{|c|}{ Regressão Polinomial para as doses de Ácido Giberélico } \\
\hline & $\begin{array}{c}\begin{array}{c}\text { Comprimento } \\
\text { médio dos engaços } \\
(\mathbf{c m})\end{array} \\
\end{array}$ & $\begin{array}{l}\text { Largura média dos } \\
\text { engaços }(\mathbf{c m})\end{array}$ & $\begin{array}{c}\text { Massa média dos } \\
\text { engaços }(\mathrm{g})\end{array}$ \\
\hline Efeito Linear & $3,808 \mathrm{~ns}^{(\mathrm{I})}$ & $6,314^{*(2)}$ & $2,107 \mathrm{~ns}$ \\
\hline Efeito Quadrático & $3,613 \mathrm{~ns}$ & $0,090 \mathrm{~ns}$ & $0,544 \mathrm{~ns}$ \\
\hline
\end{tabular}

${ }^{(1)}$ Não significativo ao nível de $5 \%$ de probabilidade.

${ }^{(2)}$ Significativo ao nível de $5 \%$ de probabilidade.

Embora na Tabela 17 tenha-se verificado efeito significativo de doses de ácido giberélico sobre o comprimento e a massa média dos cachos, na Tabela 18 nota-se que não houve significância para as regressões linear e quadrática para estas mesmas características. Talvez tal efeito pudesse ser verificado realizando-se regressões de maiores graus, porém por se tratar de doses de um regulador vegetal, na prática isto não é interessante.

Com relação à largura dos engaços nota-se efeito linear significativo para a aplicação de ácido giberélico, havendo uma tendência de aumento na largura dos engaços com o aumento das doses de ácido giberélico (Figura 22). Estes dados são concordantes com os obtidos por Kalil et al. (1999), que constataram aumento nesta característica com a aplicação de ácido giberélico. 


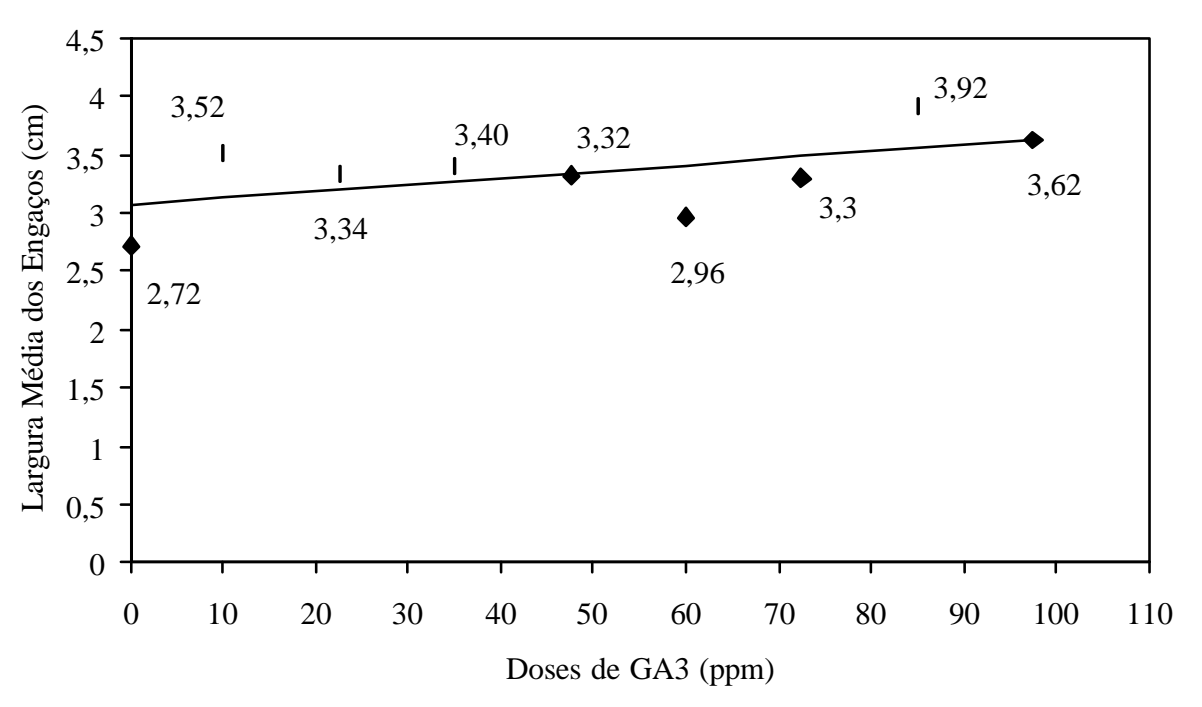

Figura 22 - Efeito de diferentes doses de ácido giberélico, sobre a largura média dos engaços da cultivar Niagara Rosada, durante o segundo ciclo vegetativo de 1999.

Tabela 19. Aplicação do teste de Tukey e de regressão polinomial para o diâmetro médio do pedicelo da cultivar Niagara Rosada durante o segundo ciclo vegetativo de 1999.

\section{Causas da Variação Teste de Tukey para as médias de anelamento dentro das doses de}

\begin{tabular}{|c|c|c|}
\hline & & \\
\hline Doses de GA3 & Sem Anelamento (A1) & Com Anelamento (A2) \\
\hline Oppm & $4,302 \mathrm{aA}^{(1)}$ & $4,183 \mathrm{aA}$ \\
\hline 10,0ppm & $4,168 \mathrm{aA}$ & $4,276 \mathrm{aA}$ \\
\hline 22,5ppm & $4,523 \mathrm{aA}$ & $4,398 \mathrm{aA}$ \\
\hline 35,0ppm & $4,524 \mathrm{aA}$ & $4,576 \mathrm{aA}$ \\
\hline 47,5ppm & $4,467 \mathrm{aA}$ & $4,534 \mathrm{aA}$ \\
\hline $60,0 \mathrm{ppm}$ & $4,271 \mathrm{bB}$ & $4,731 \mathrm{aA}$ \\
\hline 72,5ppm & $4,518 \mathrm{aA}$ & $4,389 \mathrm{aA}$ \\
\hline 85,0ppm & $4,300 \mathrm{aA}$ & $4,454 \mathrm{aA}$ \\
\hline 97,5ppm & $4,338 \mathrm{bB}$ & $4,664 \mathrm{aA}$ \\
\hline
\end{tabular}

GA3

Regressão Polinomial para as doses de Ácido Giberélico dentro dos níveis do fator anelamento

Sem Anelamento(A1) Com Anelamento (A2)

Efeito Linear $\quad 0,251 \mathrm{~ns}^{(2)}$

Efeito Quadrático $8,038 * *(3) \quad 8,599 * *$

(1) Médias dentro de uma linha seguidas de uma mesma letra minúscula ou maiúscula não diferem significativamente ao nível de $5 \%$ e $1 \%$ de probabilidade, respectivamente.

(2) Não significativo ao nível de $5 \%$ de probabilidade.

(3) Significativo ao nível de $1 \%$ de probabilidade. 
Primeiramente, nota-se na Tabela 19, que houve efeito significativo do anelamento de ramos sobre o diâmetro médio dos pedicelos apenas quando conjuntamente aplicaram-se as doses de 60 e 97,5ppm, observando-se diâmetros menores quando as mesmas doses foram aplicadas isoladamente (Figura 23).

Verifica-se na Tabela 19 que houve efeito significativo da aplicação de ácido giberélico quando esta foi realizada sozinha ou em conjunto com a técnica do anelamento.

Quando o anelamento foi realizado, notourse (Figura 24) uma tendência de aumento no diâmetro dos pedicelos com o aumento das doses, sendo que as doses de 60 e 97,5ppm de ácido giberélico originaram os maiores diâmetros, sendo estes 4,731 e $4,664 \mathrm{~mm}$, respectivamente.

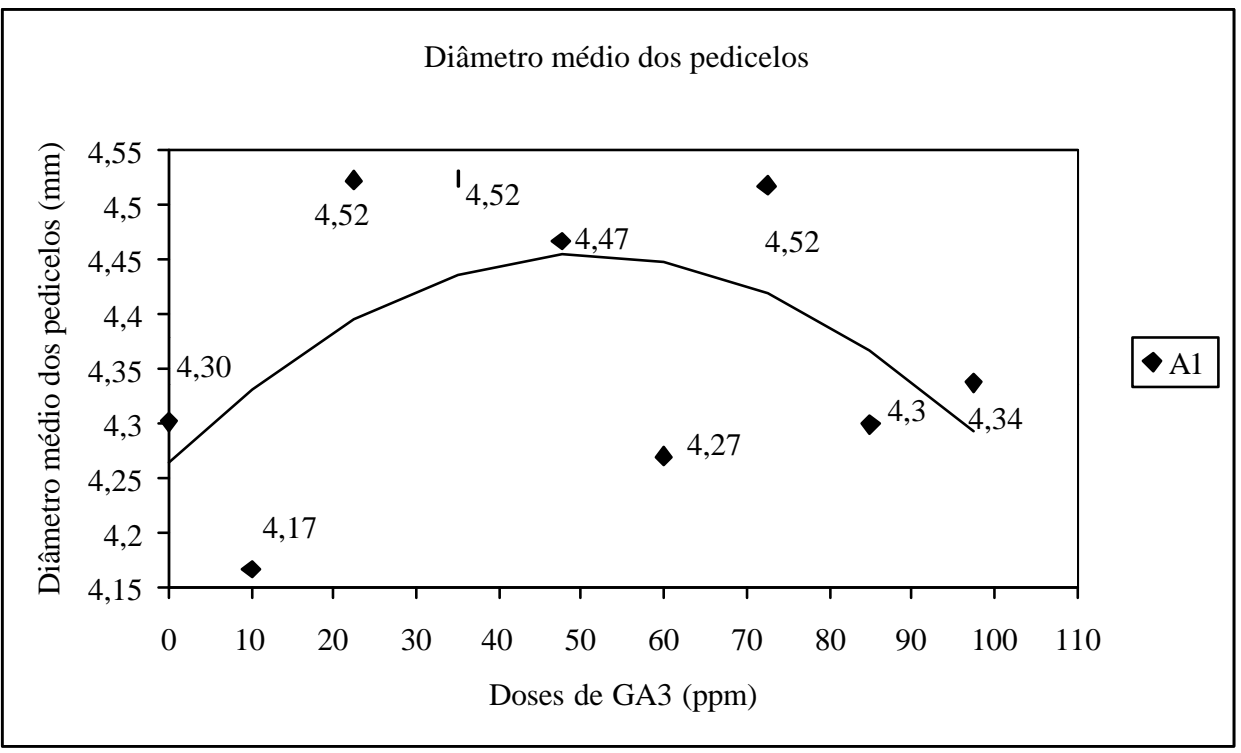

Figura 23 - Efeito da aplicação de diferentes doses de ácido giberélico, realizada isoladamente (sem a prática do anelamento de ramos), sobre o diâmetro médio dos pedicelos da cultivar Niagara Rosada, durante o segundo ciclo vegetativo de 1999. 


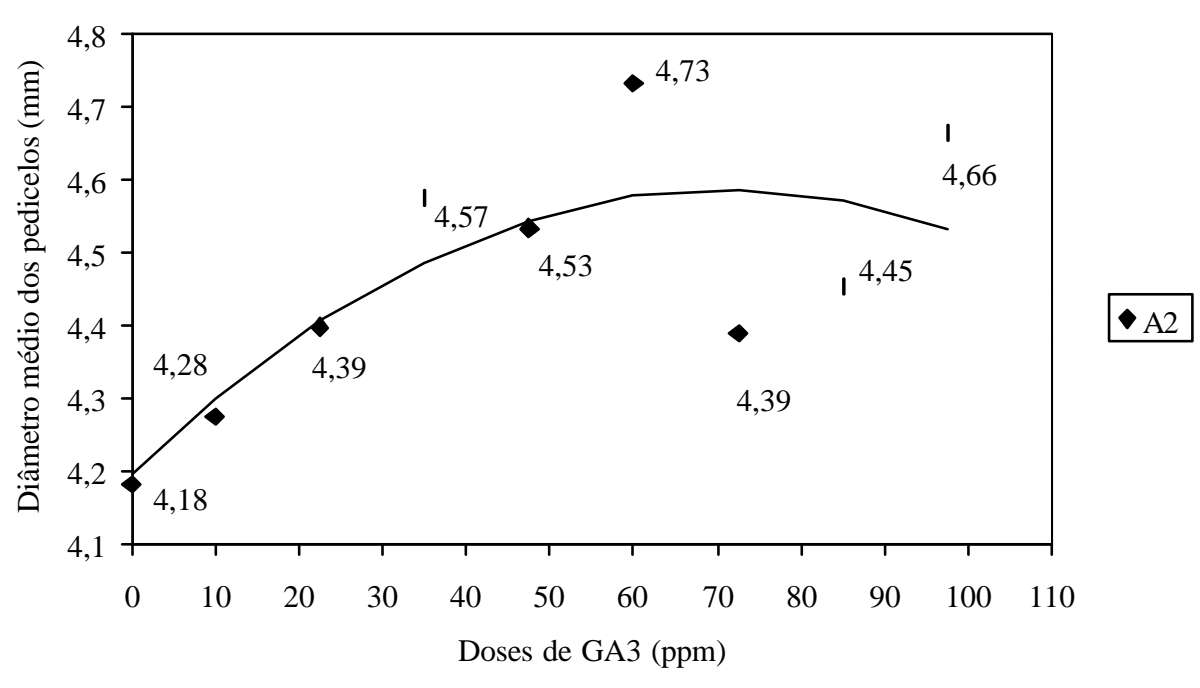

Figura 24 - Efeito da aplicação de diferentes doses de ácido giberélico, realizada juntamente com a prática do anelamento de ramos, sobre o diâmetro médio dos pedicelos da cultivar Niagara Rosada, durante o segundo ciclo vegetativo de 1999.

Tabela 20. Aplicação do Teste "F" para as características mensuradas nos bagos da cultivar Niagara Rosada durante o segundo ciclo vegetativo de 1999.

\begin{tabular}{lccccc}
\hline $\begin{array}{l}\text { Causas da } \\
\text { Variação }\end{array}$ & $\begin{array}{c}\text { Comprimento } \\
\text { de bagos }(\mathrm{mm})\end{array}$ & $\begin{array}{c}\text { Largura de } \\
\text { bagos }(\mathrm{mm})\end{array}$ & $\begin{array}{c}\text { Massa de } \\
\text { bagos }(\mathrm{g}) \\
\text { Teste “F”" }\end{array}$ & $\begin{array}{c}\text { Acidez } \\
\text { Titulável }\end{array}$ & TSS $^{(3)}\left({ }^{\circ}\right.$ Brix $)$ \\
\hline Anelamento & $18,082^{* *(2)}$ & $38,179^{* *}$ & $35,882^{* *}$ & $0,122 \mathrm{~ns}^{(1)}$ & $4,169 \mathrm{~ns}$ \\
Doses de GA3 & $15,800^{* *}$ & $15,018^{* *}$ & $20,990^{* *}$ & $10,243^{* *}$ & $9,817^{* *}$ \\
Interação & $5,191^{* *}$ & $5,070^{* *}$ & $6,872^{* *}$ & $1,531 \mathrm{~ns}$ & $6,155^{* *}$ \\
AnelxGA3 & & & & & \\
\hline
\end{tabular}

${ }^{(1)}$ Não significativo ao nível de $5 \%$ de probabilidade.

(2) Significativo ao nível de $1 \%$ de probabilidade.

${ }^{(3)}$ Teor de sólidos solúveis.

Na Tabela 20 observa-se que a interação entre os fatores foi significativa para todas as características avaliadas, exceto para a acidez total titulável, a qual sofreu influência apenas de doses de ácido giberélico. 
Tabela 21. Aplicação do teste de Tukey e de regressão polinomial para o comprimento médio dos bagos da cultivar Niagara Rosada durante o segundo ciclo vegetativo de 1999.

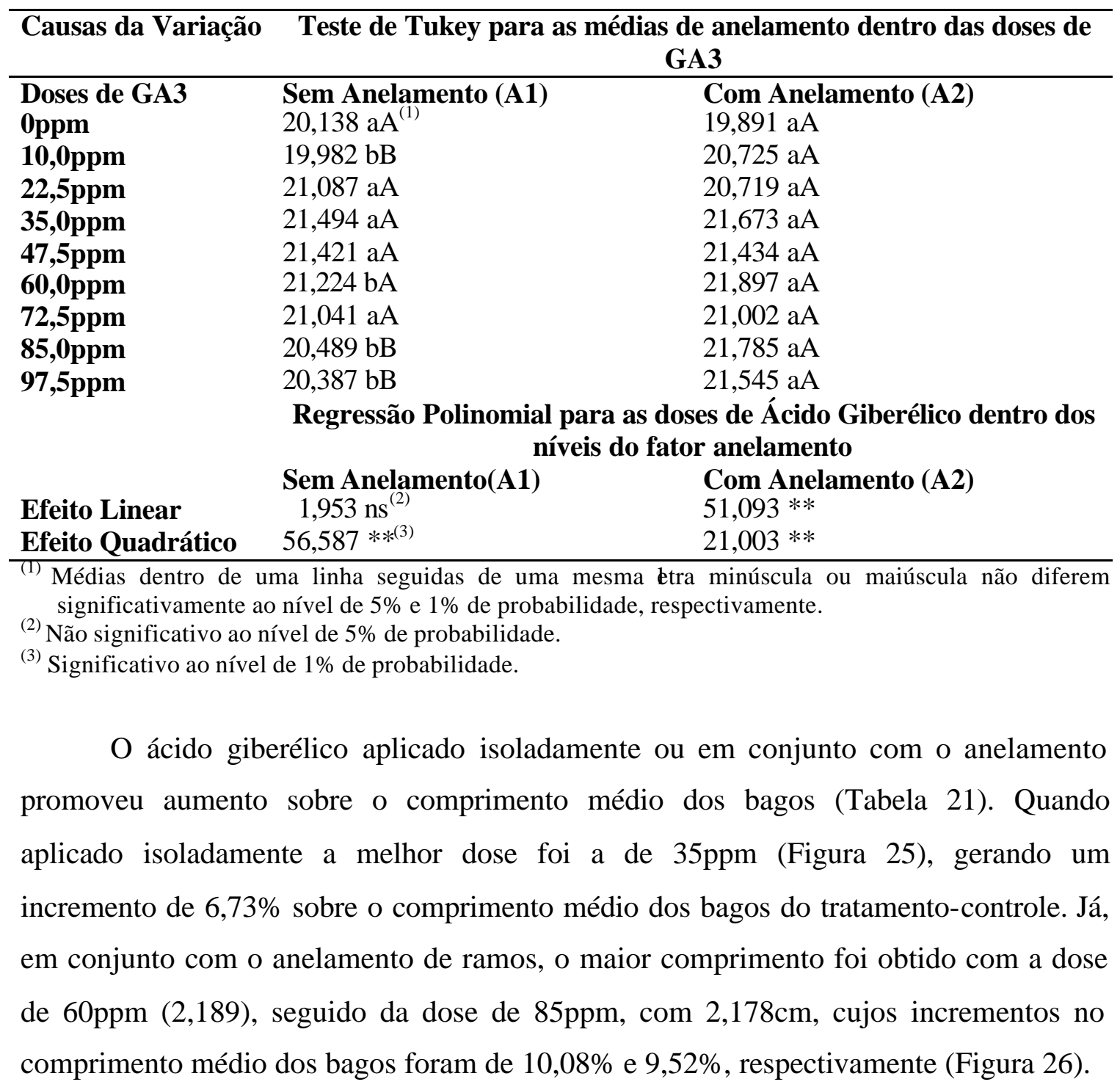




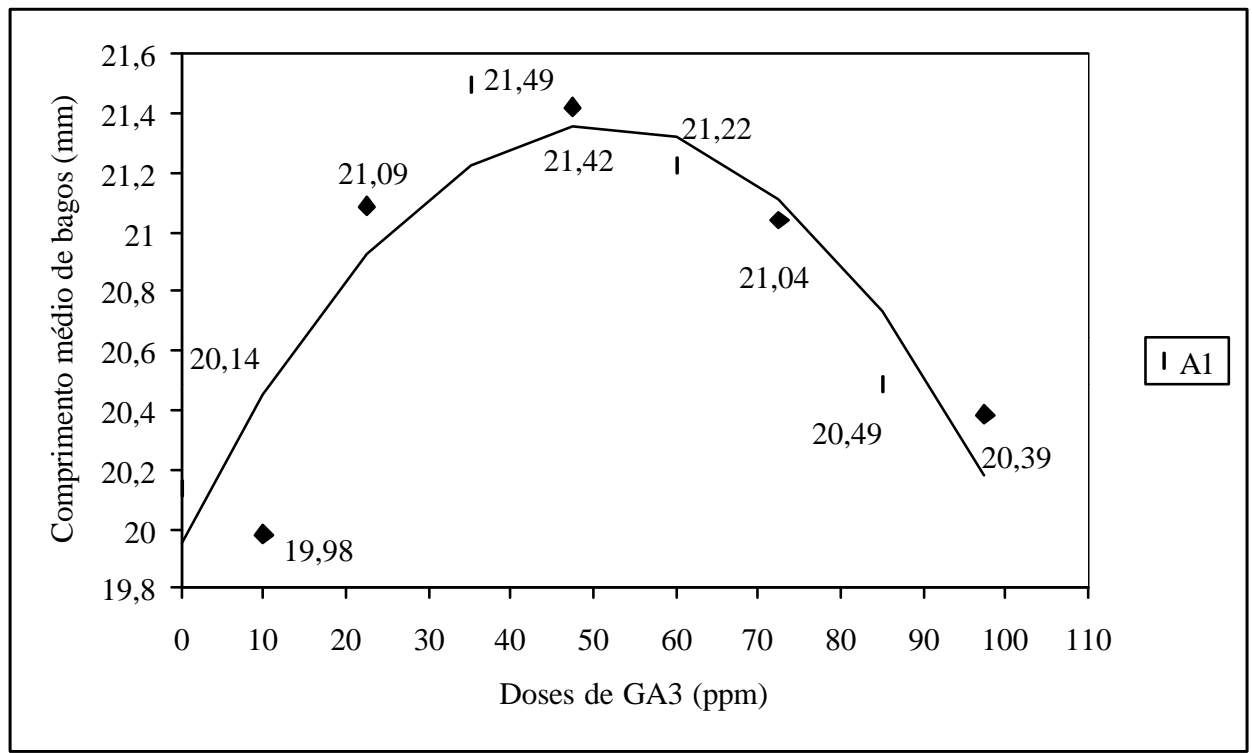

Figura 25 - Efeito da aplicação de diferentes doses de ácido giberélico, realizada isoladamente (sem a prática do anelamento de ramos), sobre o comprimento médio dos bagos da cultivar Niagara Rosada, durante o segundo ciclo vegetativo de 1999.

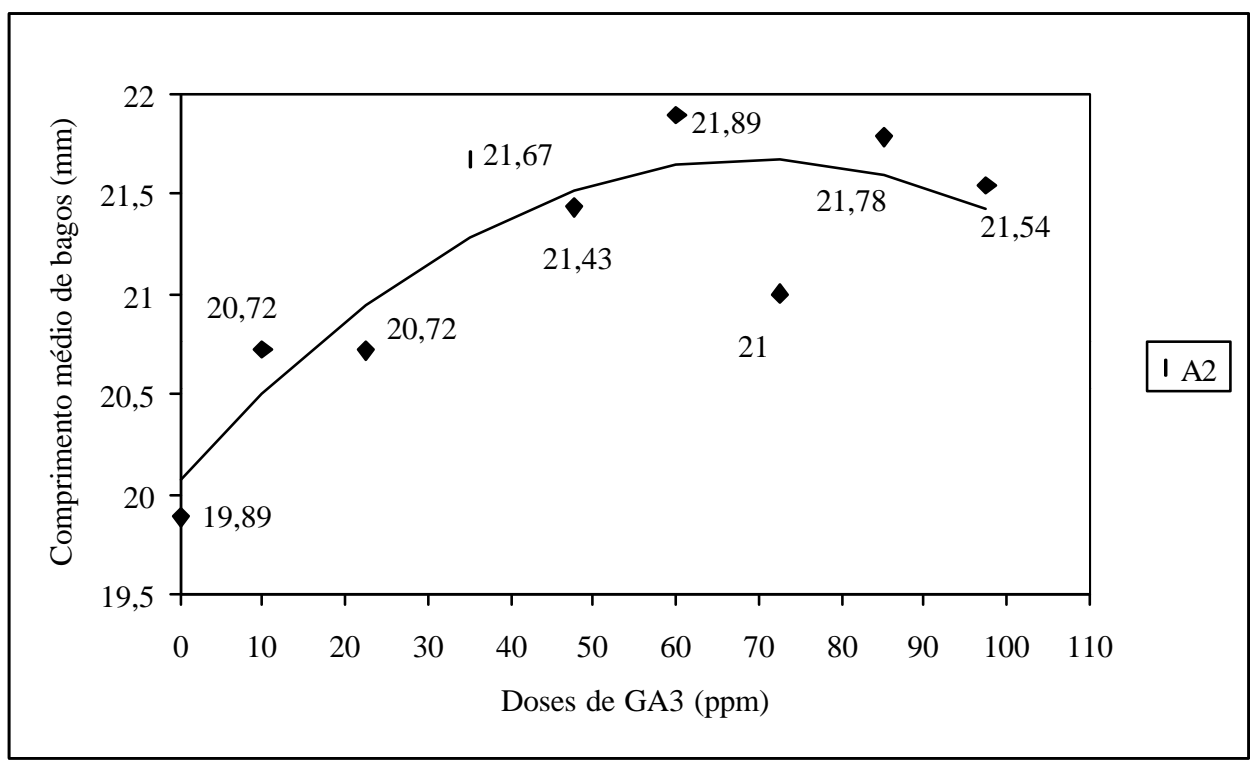

Figura 26 - Efeito da aplicação de diferentes doses de ácido giberélico, realizada juntamente com a prática do anelamento de ramos, sobre o comprimento médio dos bagos da cultivar Niagara Rosada, durante o segundo ciclo vegetativo de 1999. 
Tabela 22. Aplicação do teste de Tukey e de regressão polinomial para a largura média de bagos da cultivar Niagara Rosada durante o segundo ciclo vegetativo de 1999.

\begin{tabular}{|c|c|c|}
\hline Causas da Variação & \multicolumn{2}{|c|}{$\begin{array}{l}\text { Teste de Tukey para as médias de anelamento dentro das doses de } \\
\text { GA3 }\end{array}$} \\
\hline Doses de GA3 & Sem Anelamento (A1) & Com Anelamento (A2) \\
\hline 0ppm & $18,498 \mathrm{aA}^{(1)}$ & $18,905 \mathrm{aA}$ \\
\hline 10,0ppm & $18,663 \mathrm{bB}$ & $19,425 \mathrm{aA}$ \\
\hline $22,5 \mathrm{ppm}$ & $19,676 \mathrm{aA}$ & $19,478 \mathrm{aA}$ \\
\hline 35,0ppm & $19,701 \mathrm{aA}$ & $20,109 \mathrm{aA}$ \\
\hline 47,5ppm & $19,682 \mathrm{aA}$ & $19,811 \mathrm{aA}$ \\
\hline 60,0ppm & $19,764 \mathrm{bA}$ & $20,271 \mathrm{aA}$ \\
\hline 72,5ppm & $19,851 \mathrm{aA}$ & $19,655 \mathrm{aA}$ \\
\hline 85,0ppm & $18,983 \mathrm{bB}$ & $20,172 \mathrm{aA}$ \\
\hline \multirow[t]{3}{*}{ 97,5ppm } & $18,888 \mathrm{bB}$ & $19,908 \mathrm{aA}$ \\
\hline & \multicolumn{2}{|c|}{$\begin{array}{c}\text { Regressão Polinomial para as doses de Ácido Giberélico dentro dos } \\
\text { níveis do fator anelamento }\end{array}$} \\
\hline & Sem Anelamento(A1) & Com Anelamento (A2) \\
\hline Efeito Linear & $5,567 *(2)$ & $31,554 * *$ \\
\hline Efeito Quadrático & $77,207 * *^{(3)}$ & $15,633 * *$ \\
\hline
\end{tabular}

Assim como pode-se observar para o comprimento médio dos bagos, a largura média destes também sofreu influência do ácido giberélico sendo aplicado isoladamente ou em conjunto com a prática do anelamento de ramos (Tabela 22).

Quando da aplicação solada do regulador vegetal, a maior largura média de bagos pode ser observada com as dose de 72,5ppm (Figura 27), sendo esta 7,3\% superior à do tratamento-controle.

Já, quando conjuntamente com o ácido giberélico realizou-se o anelamento de ramos, a dose de 60ppm foi a que proporcionou o maior incremento sobre a largura média dos bagos $(7,2 \%)$ (Figura 28 ). 


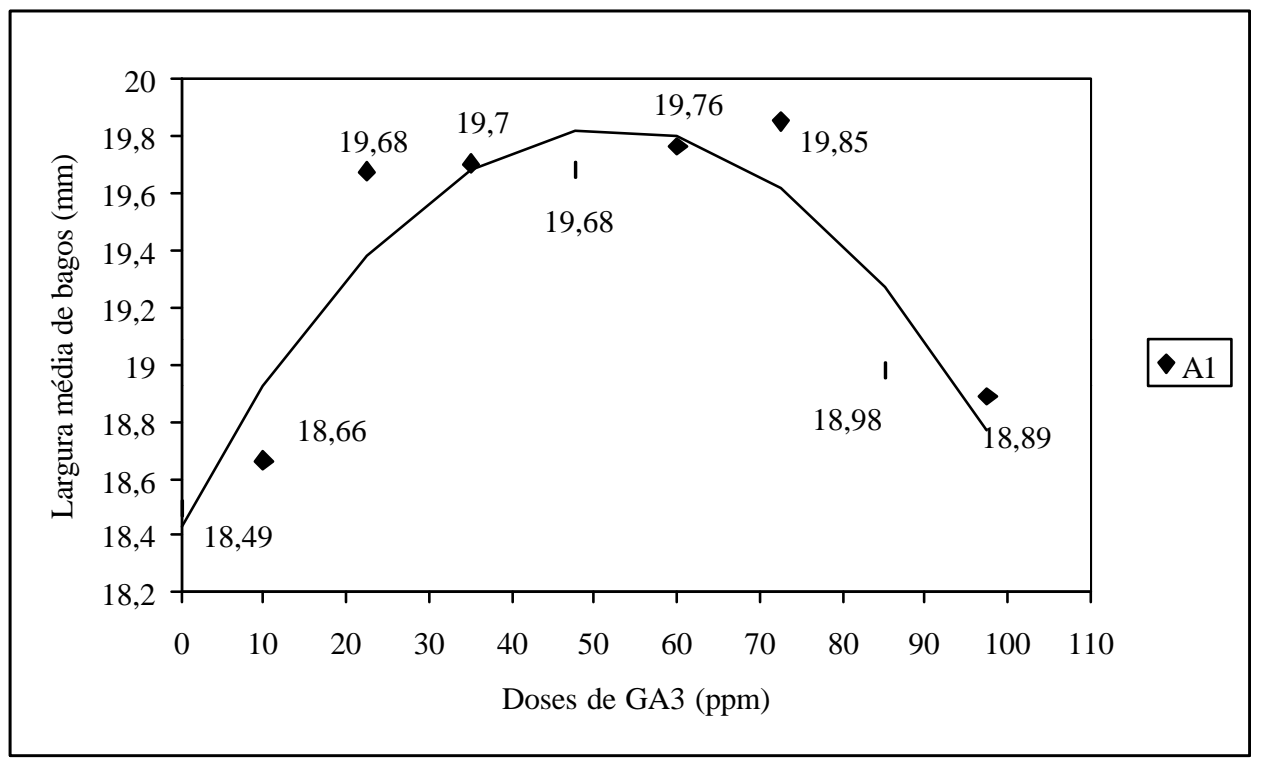

Figura 27 - Efeito da aplicação de diferentes doses de ácido giberélico, realizada isoladamente (sem a prática do anelamento de ramos), sobre a largura média dos bagos da cultivar Niagara Rosada, durante o segundo ciclo vegetativo de 1999.

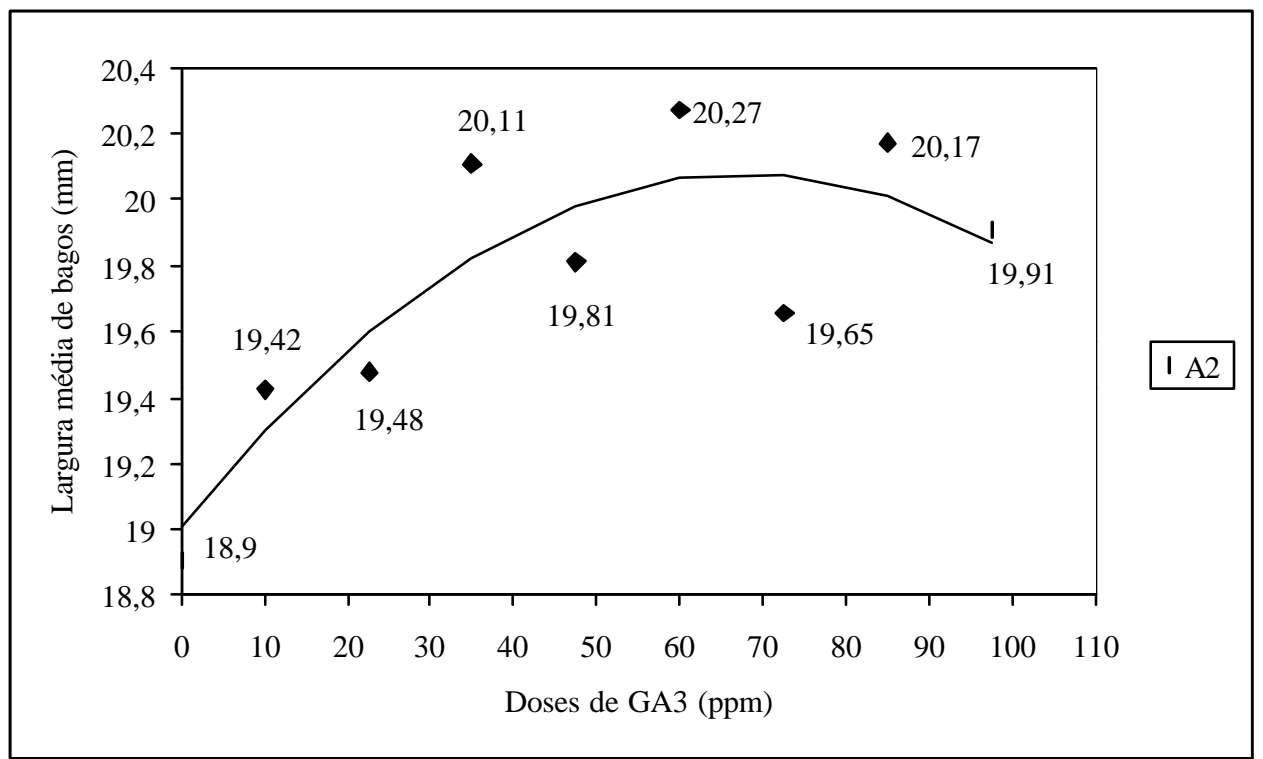

Figura 28 - Efeito da aplicação de diferentes doses de ácido giberélico, realizada juntamente com a prática do anelamento de ramos, sobre a largura média dos bagos da cultivar Niagara Rosada, durante o segundo ciclo vegetativo de 1999. 
A aplicação do ácido giberélico isoladamente ou conjuntamente com o anelamento de ramos provocou aumento significativo também na massa média dos bagos. Nota-se que o maior incremento $(25,33 \%)$ pode ser observado com a dose de 60ppm aplicada conjuntamente com o anelamento de ramos (Figura 30).

Tabela 23. Aplicação do teste de Tukey e de regressão polinomial para a massa média dos bagos da cultivar Niagara Rosada durante o segundo ciclo vegetativo de 1999.

\begin{tabular}{|c|c|c|}
\hline Causas da Variação & \multicolumn{2}{|c|}{$\begin{array}{l}\text { Teste de Tukey para as médias de anelamento dentro das doses de } \\
\text { GA3 }\end{array}$} \\
\hline Doses de GA3 & Sem Anelamento (A1) & Com Anelamento (A2) \\
\hline 0ppm & $4,491 \mathrm{aA}^{(1)}$ & $4,493 \mathrm{aA}$ \\
\hline $10,0 \mathrm{ppm}$ & $4,389 \mathrm{bB}$ & 4,789 aA \\
\hline 22,5ppm & $5,172 \mathrm{aA}$ & $4,939 \mathrm{aA}$ \\
\hline 35,0ppm & $5,314 \mathrm{aA}$ & $5,424 \mathrm{aA}$ \\
\hline 47,5ppm & $5,138 \mathrm{aA}$ & $5,155 \mathrm{aA}$ \\
\hline 60,0ppm & $5,089 \mathrm{bB}$ & $5,631 \mathrm{aA}$ \\
\hline 72,5ppm & $4,973 \mathrm{aA}$ & $5,057 \mathrm{aA}$ \\
\hline 85,0 ppm & $4,779 \mathrm{bB}$ & $5,536 \mathrm{aA}$ \\
\hline \multirow[t]{3}{*}{ 97,5ppm } & $4,747 \mathrm{bB}$ & $5,462 \mathrm{aA}$ \\
\hline & \multicolumn{2}{|c|}{$\begin{array}{c}\text { Regressão Polinomial para as doses de Ácido Giberélico dentro dos } \\
\text { níveis do fator anelamento }\end{array}$} \\
\hline & Sem Ane lamento(A1) & Com Anelamento (A2) \\
\hline Efeito Linear & $4,277^{*(2)}$ & $79,764 * *$ \\
\hline Efeito Quadrático & $59,954^{*} *(3)$ & $16,964 * *$ \\
\hline
\end{tabular}

(1) Médias dentro de uma linha seguidas de uma mesma letra minúscula ou maiúscula não diferem significativamente ao nível de $5 \%$ e $1 \%$ de probabilidade, respectivamente.

${ }^{(2)}$ Significativo ao nível de $5 \%$ de probabilidade.

${ }^{(3)}$ Significativo ao nível de $1 \%$ de probabilidade. 


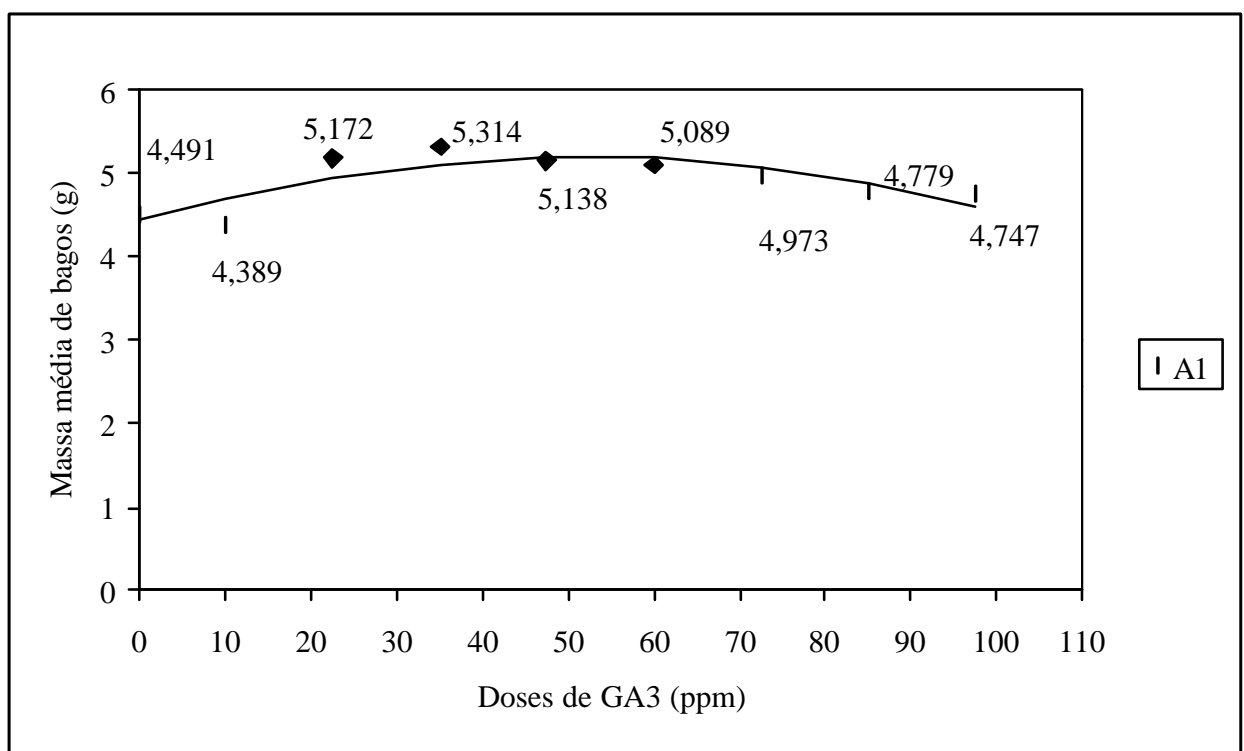

Figura 29 - Efeito da aplicação de diferentes doses de ácido giberélico, realizada isoladamente (sem a prática do anelamento de ramos), sobre a massa média dos bagos da cultivar Niagara Rosada, durante o segundo ciclo vegetativo de 1999.

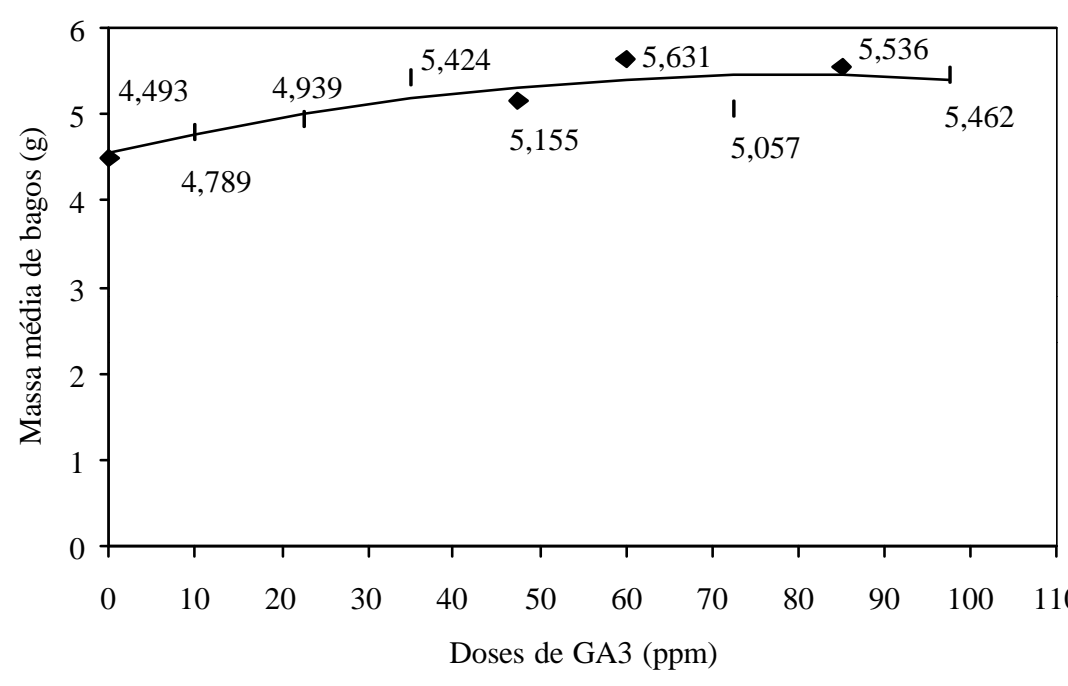

Figura 30 - Efeito da aplicação de diferentes doses de ácido giberélico, realizada juntamente com a prática do anelamento de ramos, sobre a massa média dos bagos da cultivar Niagara Rosada, durante o segundo ciclo vegetativo de 1999.

Com relação ao efeito do ácido giberélico sobre tais características dos bagos, outros autores já obtiveram resultados semelhantes. Segundo Kalil et al. (1999), a 
aplicação deste regulador provocou aumento de $98,8 \%$ na massa dos bagos e de 46,8\% e 43,1\% no comprimento e largura dos bagos da uva 'Maria'. Também, Sarooshi (1977) verificou que pulverizações do ácido giberélico na cultivar Sultana, produziu aumento na massa e no tamanho dos bagos.

Tabela 24. Aplicação de regressão polinomial para a acidez titulável da cultivar Niagara Rosada durante o segundo ciclo vegetativo de 1999.

\begin{tabular}{cc}
\hline & Regressão Polinomial para as doses de Ácido Giberélico \\
\hline Efeito Linear & $42,576 * 6^{*(1)}$ \\
Efeito Quadrático & $8,919 * *$ \\
\hline
\end{tabular}

(1) Significativo ao nível de $1 \%$ de probabilidade.

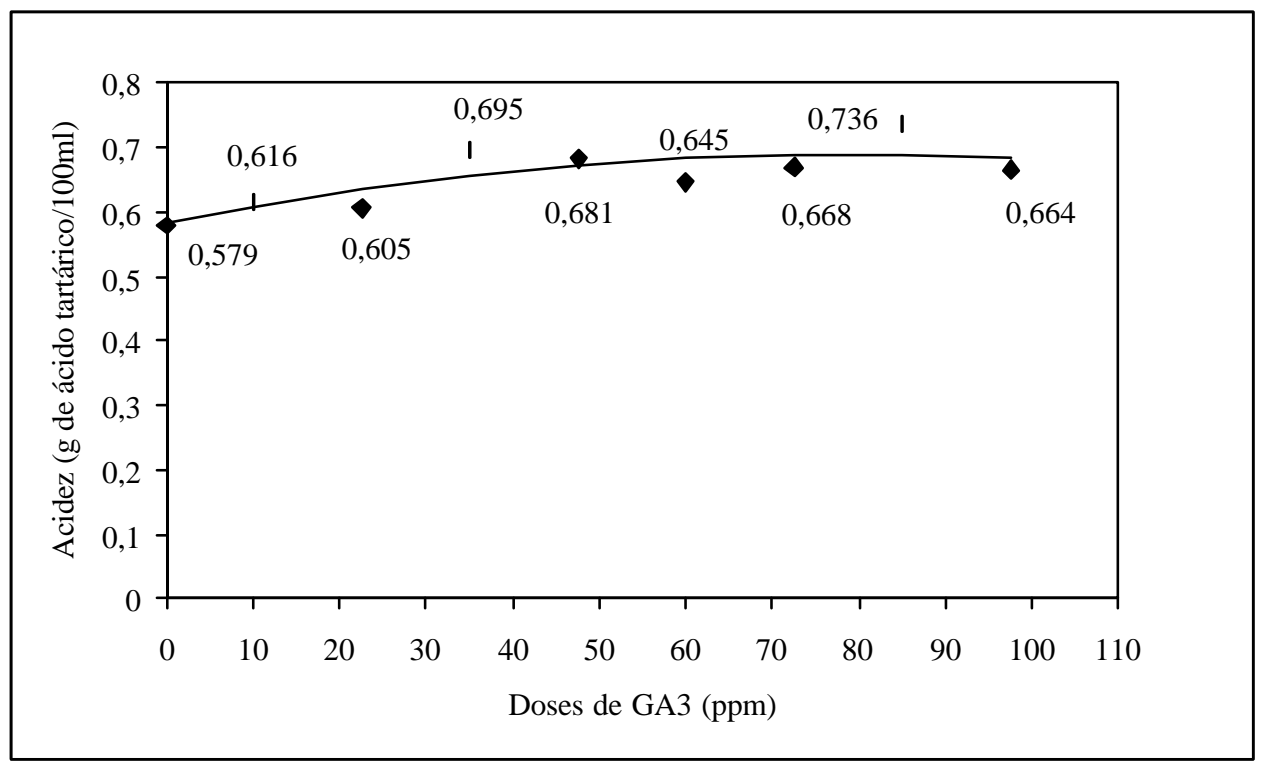

Figura 31 - Efeito de diferentes doses de ácido giberélico, sobre a acidez titulável da cultivar Niagara Rosada, durante o segundo ciclo vegetativo de 1999.

A acidez titulável foi afetada significativamente apenas por doses de ácido giberélico. Notou-se uma tendência em aumentar a acidez titulável com o aumento da dose de ácido giberélico (Figura 31). Isto, talvez, deva-se ao fato de o ácido giberélico atrasar a maturação dos frutos.

No tratamento em que a dose de 0ppm de ácido giberélico foi aplicada a acidez total titulável foi de $0,58 \mathrm{~g}$ de ácido tartárico/100ml, ao passo que a dose de 60ppm, a 
qual promoveu maior incremento no tamanho e massa dos bagos, apresentou acidez de $0,64 \mathrm{~g}$ de ácido tatárico/100ml.

Tabela 25. Aplicação do teste de Tukey e de regressão polinomial para o teor de sólidos solúveis da cultivar Niagara Rosada durante o primeiro ciclo vegetativo de 1999.

\begin{tabular}{|c|c|c|}
\hline Causas da Variação & \multicolumn{2}{|c|}{$\begin{array}{l}\text { Teste de Tukey para as médias de anelamento dentro das doses de } \\
\text { GA3 }\end{array}$} \\
\hline Doses de GA3 & Sem Anelamento (A1) & Com Anelamento (A2) \\
\hline Oppm & $15,370 \mathrm{aA}^{(1)}$ & $14,810 \mathrm{aA}$ \\
\hline 10,0ppm & $14,850 \mathrm{aA}$ & $13,440 \mathrm{bB}$ \\
\hline $22,5 \mathrm{ppm}$ & $15,000 \mathrm{bB}$ & $16,780 \mathrm{aA}$ \\
\hline 35,0ppm & $14,860 \mathrm{aA}$ & $15,180 \mathrm{aA}$ \\
\hline 47,5ppm & $14,780 \mathrm{aA}$ & $15,490 \mathrm{aA}$ \\
\hline 60,0ppm & $14,800 \mathrm{aA}$ & $14,830 \mathrm{aA}$ \\
\hline 72,5ppm & $14,530 \mathrm{aA}$ & $15,080 \mathrm{aA}$ \\
\hline $85,0 \mathrm{ppm}$ & $13,610 \mathrm{aA}$ & $14,320 \mathrm{aA}$ \\
\hline \multirow[t]{3}{*}{ 97,5ppm } & $14,840 \mathrm{aA}$ & $14,910 \mathrm{aA}$ \\
\hline & \multicolumn{2}{|c|}{$\begin{array}{c}\text { Regressão Polinomial para as doses de Ácido Giberélico dentro dos } \\
\text { níveis do fator anelamento }\end{array}$} \\
\hline & Sem Anelamento(A1) & Com Anelamento (A2) \\
\hline Efeito Linear & $11,959 * *(3)$ & $0,147 \mathrm{~ns}^{(2)}$ \\
\hline Efeito Quadrático & $0,474 \mathrm{~ns}$ & $13,745 * *$ \\
\hline
\end{tabular}

Na Figura 32 verifica-se que quando foi feita a aplicação de ácido giberélico isoladamente, houve uma diminuição no teor de sólidos solúveis com o aumento das doses de ácido giberélico, observando-se o maior valor quando o regulador vegetal não foi aplicado $\left(15,37^{\circ}\right.$ Brix $)$, e o menor com a dose de $85 \mathrm{ppm}\left(13,61^{\circ}\right.$ Brix $)$. No entanto, quando a aplicação deste regulador vegetal foi realizada conjuntamente com o anelamento de ramos, pode-se até notar um aumento no teor de sólidos solúveis, sendo que as doses de 22,5; 35 e 47,5 proporcionaram os maiores teores de sólidos solúveis totais, 16,78; 15,18 e 15,49 Brix, respectivamente (Figura 33). Isto sugere que, maiores doses de ácido giberélico endem a atrasar a maturação dos cachos, porém, tal efeito pode ser minimizado realizando-se, conjuntamente, o anelamento de ramos. 


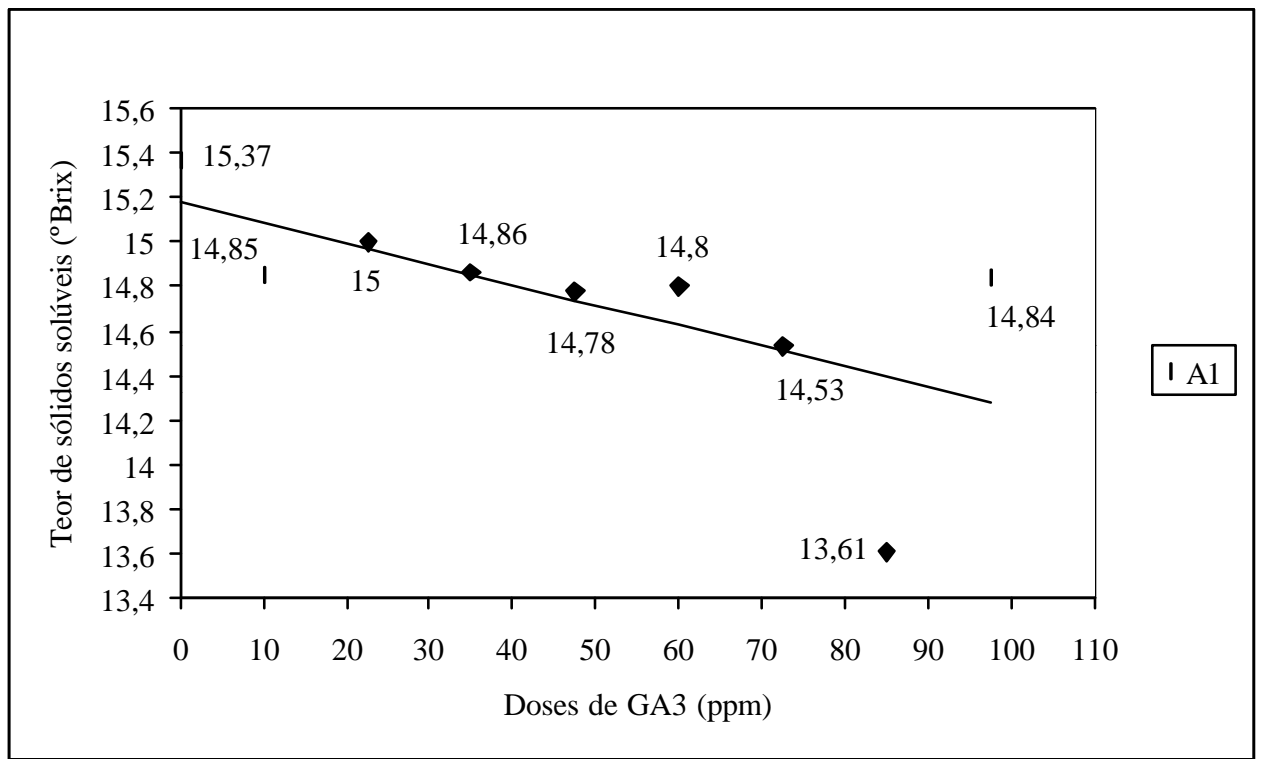

Figura 32 - Efeito da aplicação de diferentes doses de ácido giberélico, realizada isoladamente (sem a prática do anelamento de ramos), sobre o teor de sólidos solúveis da cultivar Niagara Rosada, durante o segundo ciclo vegetativo de 1999.

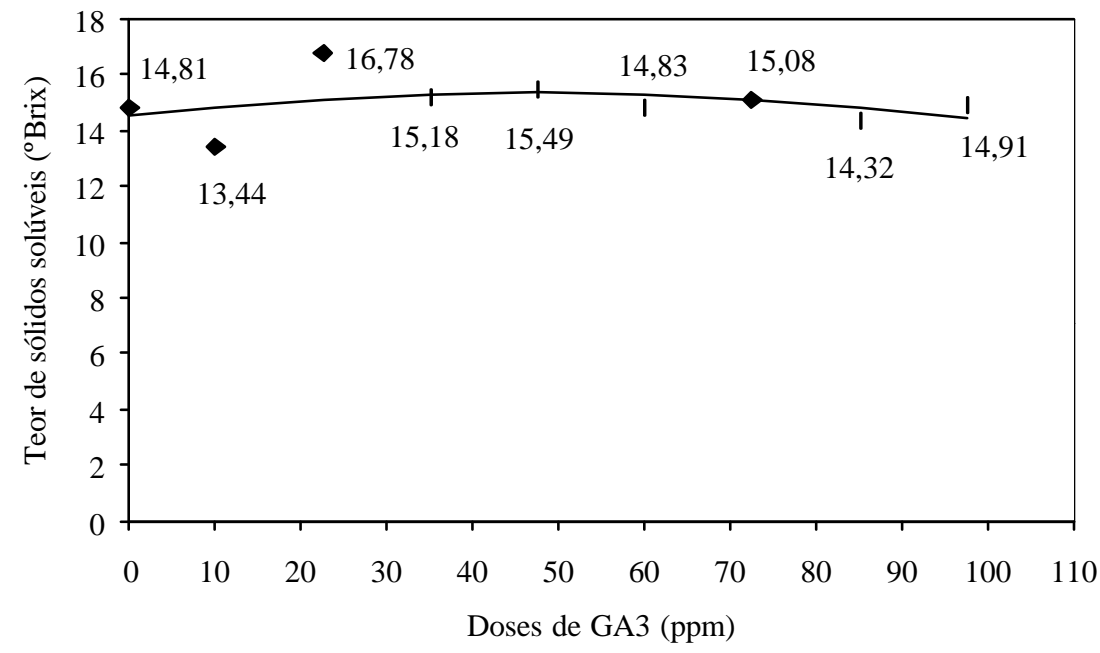

Figura 33 - Efeito da aplicação de diferentes doses de ácido giberélico, realizada juntamente com a prática do anelamento de ramos, sobre teor de sólidos solúveis da cultivar Niagara Rosada, durante o segundo ciclo vegetativo de 1999. 
De uma maneira geral, notourse que neste segundo experimento com a cultivar Niagara Rosada, o anelamento de ramos sendo realizado conjuntamente com a aplicação de doses de ácido giberélico promoveu os maiores incrementos na massa e largura dos cachos e bagos, e no comprimento de bagos. Nota-se que, os maiores incrementos no tamanho e massa dos bagos foram obtidos com a dose de 60ppm aplicada conjuntamente com o anelamento. Já, no caso da largura e massa dos cachos, os maiores valores foram observados com a dose de 35ppm. Embora não tenha sido significativo, notourse na Tabela 16 que, o número médio de bagos por cacho foi maior quando o anelamento foi realizado conjuntamente com a dose de 35ppm, o que pode ter contribuído para um aumento na massa dos cachos com a aplicação desta dose.

\subsection{Experimentos com a cultivar Vênus}

Nos dois experimentos com a cultivar Vênus o delineamento experimental foi em blocos ao acaso com 28 tratamentos e 5 repetições no esquema fatorial 4x7. Houve a combinação dos dois seguintes fatores: 1) técnicas e 2) doses de ácido giberélico (Quadro 4).

\begin{tabular}{|l|l|}
\hline \multicolumn{2}{|l|}{ Anelamento } \\
\hline Técnica 1 & Sem Anelamento e Sem Desponte \\
Técnica 2 & Com Anelamento e Sem Desponte \\
Técnica 3 & Sem Anelamento e Com Desponte \\
Técnica 4 & Com Anelamento e Com Desponte \\
\hline \multicolumn{2}{|l|}{ Doses } \\
\hline Dose 1 & Oppm \\
Dose 2 & $10 \mathrm{ppm}$ \\
Dose 3 & $22,5 \mathrm{ppm}$ \\
Dose 4 & $35 \mathrm{ppm}$ \\
Dose 5 & $47,5 \mathrm{ppm}$ \\
Dose 6 & $60 \mathrm{ppm}$ \\
Dose 7 & $72,5 \mathrm{ppm}$ \\
\hline
\end{tabular}

Quadro 4 - Conjunto dos fatores que compõem o fatorial. 


\subsubsection{Cultivar Vênus - Ciclo vegetativo de 1999}

Nas Tabelas 26 à 29 são apresentados os resultados das análises estatísticas para os parâmetros avaliados nos cachos da cultivar Vênus durante o ciclo vegetativo de 1999.

Tabela 26. Aplicação do Teste "F" para as características mensuradas nos cachos da cultivar Vênus durante o ciclo vegetativo de 1999.

\begin{tabular}{lcccl}
\hline $\begin{array}{l}\text { Causas da } \\
\text { Variação }\end{array}$ & $\begin{array}{l}\text { Comprimento de } \\
\text { cachos }(\mathrm{cm})\end{array}$ & $\begin{array}{l}\text { Largura de } \\
\text { cachos }(\mathrm{cm})\end{array}$ & $\begin{array}{l}\text { Massa de cachos } \\
(\mathrm{g}) \\
\text { Teste “F” }\end{array}$ & $\begin{array}{l}\text { Número de } \\
\text { bagos/cacho }\end{array}$ \\
\hline Técnicas & $29,827^{* *(3)}$ & $0,846 \mathrm{~ns}$ & $15,129 * *$ & $1,309 \mathrm{~ns}$ \\
Doses de GA3 & $1,499 \mathrm{~ns}^{(1)}$ & $0,503 \mathrm{~ns}$ & $1,179 \mathrm{~ns}$ & $3,553 * *$ \\
Interação & $2,277^{* *}$ & $1,417 \mathrm{~ns}$ & $2,077^{*(2)}$ & $2,591 * *$ \\
Técnicas x GA3 & & & & \\
\hline
\end{tabular}

(1) Não significativo ao nível de 5\% de probabilidade.

${ }^{(2)}$ Significativo ao nível de $5 \%$ de probabilidade.

${ }^{(3)}$ Significativo ao nível de $1 \%$ de probabilidade.

Analisando a Tabela 26, nota-se interação significativa entre os fatores para o comprimento e a massa de cachos e o número médio de bagos por cacho. Já, a largura média de cachos não foi afetada significativamente pelos diferentes tratamentos.

Tabela 27. Aplicação do teste de Tukey e de regressão polinomial para o comprimento médio dos cachos da cultivar Vênus durante o ciclo vegetativo de 1999.

\begin{tabular}{|c|c|c|c|c|}
\hline \multirow{2}{*}{$\begin{array}{l}\text { Causas da variação } \\
\text { Doses de GA3 }\end{array}$} & \multicolumn{4}{|c|}{$\begin{array}{l}\text { Teste de Tukey para as médias das técnicas dentro das doses } \\
\text { de GA3 }\end{array}$} \\
\hline & Técnica 1 & Técnica 2 & Técnica 3 & Técnica 4 \\
\hline Oppm & $17,330 \mathrm{a} \mathrm{AB}^{(1)}$ & 18,725 a $\mathrm{A}$ & $15,305 \mathrm{~b} \mathrm{BC}$ & 15,015 b C \\
\hline 10,0ppm & 15,860 a $\mathrm{A}$ & 17,575 a $\mathrm{A}$ & 16,080 a $A$ & 17,105 a $\mathrm{A}$ \\
\hline $22,5 \mathrm{ppm}$ & 17,135 a $\mathrm{AB}$ & 17,345 a $\mathrm{A}$ & 14,905 b B & $15,930 \mathrm{ab} \mathrm{AB}$ \\
\hline $35,0 \mathrm{ppm}$ & $16,835 \mathrm{ab} A B$ & 18,160 a $\mathrm{A}$ & 15,540 b B & 15,845 b B \\
\hline 47,5ppm & 17,180 a $\mathrm{A}$ & 17,780 a $\mathrm{A}$ & 14,765 b B & 14,395 b B \\
\hline $60,0 \mathrm{ppm}$ & 17,565 a $A B$ & 18,105 a $\mathrm{A}$ & $15,575 \mathrm{~b} \mathrm{~B}$ & $16,975 \mathrm{ab} A B$ \\
\hline \multirow[t]{3}{*}{ 72,5ppm } & 17,870 a $\mathrm{A}$ & $16,420 \mathrm{ab} A$ & $16,170 \mathrm{ab} A$ & 15,675 b A \\
\hline & \multicolumn{4}{|c|}{$\begin{array}{c}\text { Regressão Polinomial para as doses de Ácido Giberélico dentro dos } \\
\text { níve is do fator técnicas }\end{array}$} \\
\hline & Técnica 1 & Técnica 2 & Técnica 3 & Técnica 4 \\
\hline Efeito Linear & $3,726 \mathrm{~ns}^{(2)}$ & $3,877 *^{(3)}$ & $0,283 \mathrm{~ns}$ & $0,00005 \mathrm{~ns}$ \\
\hline Efeito Quadrático & $1,129 \mathrm{~ns}$ & $0,357 \mathrm{~ns}$ & $1,999 \mathrm{~ns}$ & $0,0002 \mathrm{~ns}$ \\
\hline
\end{tabular}


Na Tabela 27 nota-se que o desponte de cachos, sendo realizado isoladamente ou em conjunto com o anelamento de ramos, reduziu significativamente o comprimento dos cachos quando, conjuntamente, aplicaram-se as doses de 0; 35 e 47,5ppm de ácido giberélico. Esta tendência pode ser observada para todas as outras doses, embora tal efeito não tenha sido significativo. Isto já era esperado, visto que o desponte de cachos promove encurtamento dos mesmos.

Também na Tabela 27 constata-se que houve diferença significativa entre as doses de ácido giberélico sobre o comprimento médio dos cachos, apenas quando conjuntamente realizou-se o anelamento de ramos. Na Figura 34 observa-se uma tendência de diminuir o comprimento médio dos cachos com o aumento das doses do regulador vegetal. O maior comprimento médio de cacho pode ser observado quando não se aplicou o ácido giberélico (0ppm), seguido das doses 35 e 60ppm, cujos valores observados foram: 18,$275 ; 18,160$ e 18,105 , respectivamente.

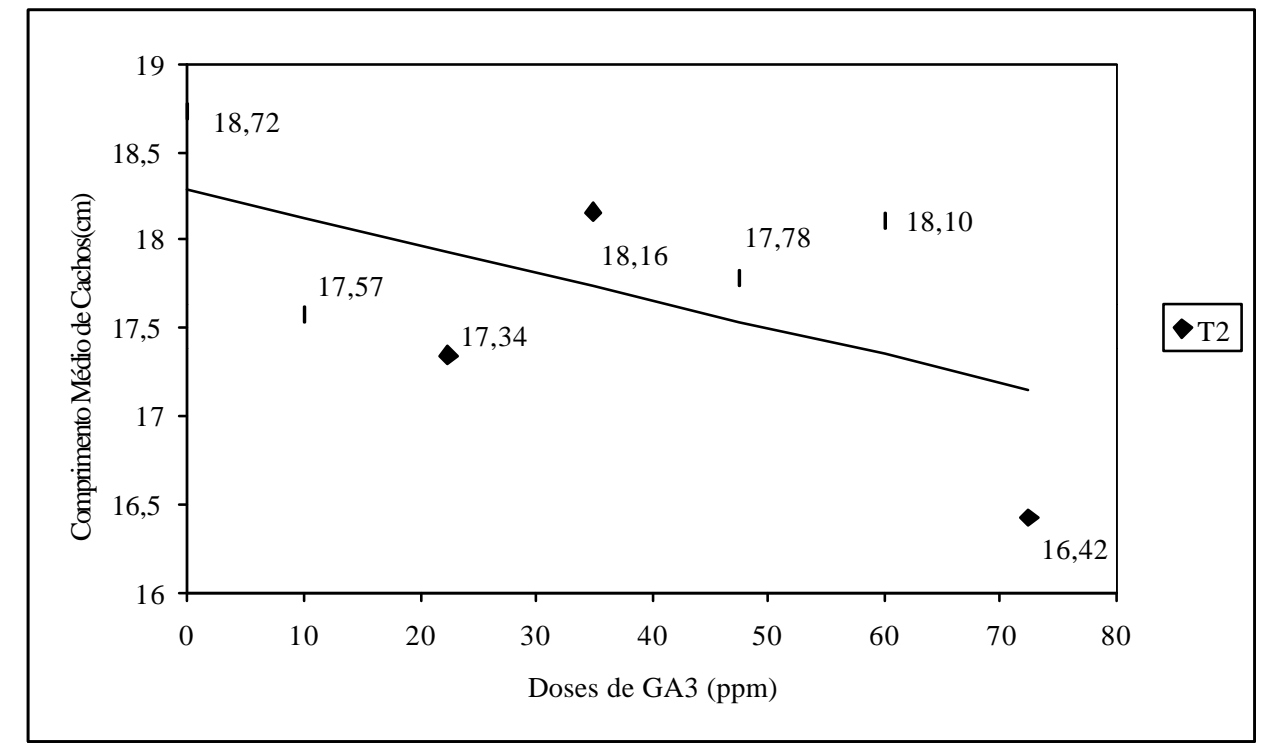

Figura 34 - Efeito da aplicação de diferentes doses de ácido giberélico, realizada juntamente com a prática do anelamento de ramos, sobre o comprimento médio dos cachos da cultivar Vênus, durante o ciclo vegetativo de 1999. 
Tabela 28. Aplicação do teste de Tukey e de regressão polinomial para a massa média dos cachos da cultivar Vênus durante o ciclo vegetativo de 1999.

\begin{tabular}{|c|c|c|c|c|}
\hline Causas da variação & \multicolumn{4}{|c|}{$\begin{array}{l}\text { Teste de Tukey para as médias das técnicas dentro das doses de } \\
\text { GA3 }\end{array}$} \\
\hline Doses de GA3 & Técnica 1 & Técnica 2 & Técnica 3 & Técnica 4 \\
\hline 0ppm & $291,645 \mathrm{aA}^{(1)}$ & $340,178 \mathrm{aA}$ & $276,165 \mathrm{aA}$ & $26 \mathrm{aA}$ \\
\hline 10,0ppm & 247,465 b B & $308,535 \mathrm{ab} A B$ & $308,145 \mathrm{ab} A B$ & 368,375 a A \\
\hline 22,5ppm & 268,065 a A & 301,079 a A & 310,225 a A & 312,925 a A \\
\hline 35,0ppm & 270,940 a $\mathrm{A}$ & 340,250 a $\mathrm{A}$ & 268,709 a $A$ & 303,655 a A \\
\hline 47,5ppm & 249,555 a $\mathrm{A}$ & 319,555 a $\mathrm{A}$ & 263,793 a $A$ & 9 a A \\
\hline 60,0ppm & 255,168 b B & $303,354 \mathrm{~b} \mathrm{AB}$ & 282,885 b B & 387,090 a A \\
\hline \multirow[t]{3}{*}{ 72,5ppm } & 230,160 b B & 334,551 a A & 315,455 a $\mathrm{AB}$ & 304,375 a $\mathrm{AB}$ \\
\hline & \multicolumn{4}{|c|}{$\begin{array}{l}\text { Regressão Polinomial para as doses de Ácido Giberélico dentro dos } \\
\text { níveis do fator técnicas }\end{array}$} \\
\hline & Técnica 1 & Técnica 2 & Técnica 3 & Técnica 4 \\
\hline Efeito Linear & $3,058 \mathrm{~ns}^{(2)}$ & $0,002 \mathrm{~ns}$ & $0,031 \mathrm{~ns}$ & $0,059 \mathrm{~ns}$ \\
\hline Efeito Quadrático & $0,046 \mathrm{~ns}$ & $0,575 \mathrm{~ns}$ & $1,035 \mathrm{~ns}$ & $0,087 \mathrm{~ns}$ \\
\hline
\end{tabular}

(1) Médias dentro de uma linha seguidas de uma mesma letra minúscula ou maiúscula não diferem significativamente ao nível de $5 \%$ e $1 \%$ de probabilidade, respectivamente.

${ }^{(2)}$ Não significativo ao nível de $5 \%$ de probabilidade.

Com relação à massa média dos cachos, observa-se (Tabela 28) que não houve diferença significativa entre as doses de ácido giberélico sendo aplicadas isoladamente ou conjuntamente com o anelamento e/ou com o desponte de cachos. Comparando-se as diferentes técnicas nota-se que, embora os resultados não tenham sido significativos para todas as doses, o anelamento de ramos sendo realizado isoladamente ou conjuntamente com o desponte de cachos proporcionou maiores massas de cachos.

Com isto, pode-se concluir que o anelamento de ramos é uma técnica interessante para se aumentar a massa de cachos. Também, a porção do cacho retirada com a prática do desponte, não afetou significativamente a massa média dos cachos, mostrando ser esta uma prática que visa melhorar as características dos cachos, tornando-os mais cônicos, melhorando, desta forma, o acondicionamento dos mesmos em embalagens para a comercialização. 
Tabela 29. Aplicação do teste de Tukey e de regressão polinomial para o número médio de bagos por cacho da cultivar Vênus durante o ciclo vegetativo de 1999.

\begin{tabular}{|c|c|c|c|c|}
\hline Causas da variação & \multicolumn{4}{|c|}{ Teste de Tukey para as médias das técnicas dentro das doses de GA3 } \\
\hline Doses de GA3 & Técnica 1 & Técnica 2 & Técnica 3 & Técnica 4 \\
\hline 0ppm & 129,350 a $\mathrm{A}^{(1)}$ & $110,000 \mathrm{ab} A B$ & $100,100 \mathrm{~b} \mathrm{AB}$ & $92,400 \mathrm{~b} \mathrm{~B}$ \\
\hline $10,0 \mathrm{ppm}$ & 93,050 a $\mathrm{A}$ & 103,100 a $\mathrm{A}$ & 105,750 a $\mathrm{A}$ & 99,700 a $\mathrm{A}$ \\
\hline 22,5ppm & $90,200 \mathrm{ab} A$ & 87,050 b A & 111,300 a $A$ & $93,750 \mathrm{ab} A$ \\
\hline 35,0ppm & 100,250 a $A$ & 103,800 a $A$ & 95,750 a $\mathrm{A}$ & 104,550 a $A$ \\
\hline 47,5ppm & $88,100 \mathrm{ab} A$ & 99,950 a $\mathrm{A}$ & $93,000 \mathrm{ab} \mathrm{A}$ & $73,800 \mathrm{~b} \mathrm{~A}$ \\
\hline 60,0ppm & 93,950 a $\mathrm{A}$ & 91,700 a $\mathrm{A}$ & 101,850 a $\mathrm{A}$ & 114,500 a $\mathrm{A}$ \\
\hline 72,5ppm & 87,300 a $\mathrm{A}$ & 95,150 a $\mathrm{A}$ & 105,850 a $\mathrm{A}$ & 87,250 a $\mathrm{A}$ \\
\hline
\end{tabular}

Regressão Polinomial para as doses de Ácido Giberélico dentro dos

$\begin{array}{lllll} & \text { Técnica 1 } & \text { Técnica 2 } & \text { Técnica 3 } & \text { Técnica 4 } \\ \text { Efeito Linear } & 12,493 * *^{(4)} & 2,359 \mathrm{~ns}^{(2)} & 0,074 \mathrm{~ns} & 0,035 \mathrm{~ns} \\ \text { Efeito Quadrático } & 5,352^{*(3)} & 0,639 \mathrm{~ns} & 0,448 \mathrm{~ns} & 0,108 \mathrm{~ns}\end{array}$

${ }^{(1)}$ Médias dentro de uma linha seguidas de uma mesma letra minúscula ou maiúscula não diferem significativamente ao nível de $5 \%$ e $1 \%$ de probabilidade, respectivamente.

(2) Não significativo ao nível de $5 \%$ de probabilidade.

${ }^{(3)}$ Significativo ao nível de $5 \%$ de probabilidade.

${ }^{(4)}$ Significativo ao nível de $1 \%$ de probabilidade.

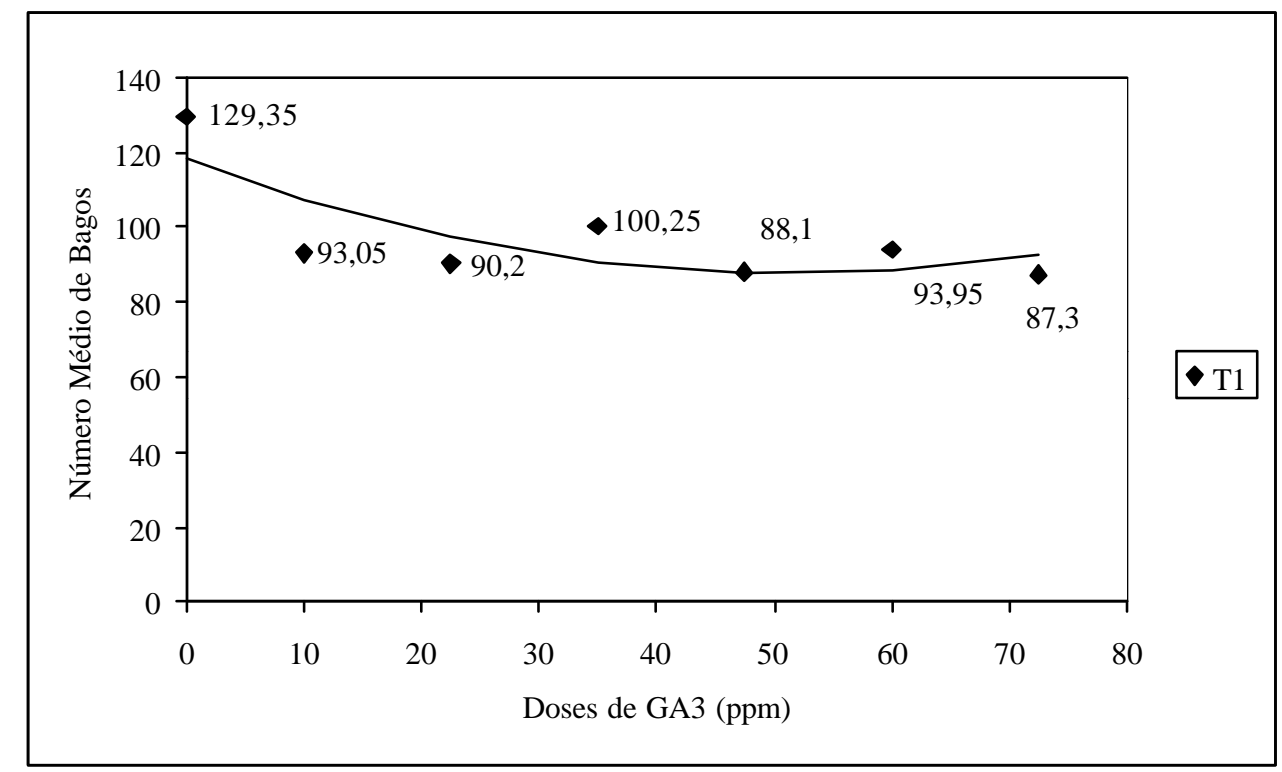

Figura 35 - Efeito da aplicação de diferentes doses de ácido giberélico, realizada isoladamente (sem a prática do anelamento de ramos e/ou desponte de cachos), sobre o número médio de bagos por cacho da cultivar Vênus, durante o ciclo vegetativo de 1999. 
Houve efeito significativo de doses sobre o número médio de bagos por cacho apenas quando o regulador vegetal foi aplicado isoladamente (Tabela 29), sendo que maiores números de bagos por cacho foram obtidos com as dose 0ppm e 35ppm de ácido giberélico, cujos valores médios foram 129,35 e 100,25 bagos/cacho (Figura 35), havendo uma tendência em diminuir o número de bagos por cacho com o aumento da dose de ácido giberélico.

Estes resultados concordam em parte com àqueles obtidos por Altaf et al. (1983), que trabalhando com a cultivar Flame Seedless, não obtiveram aumentos significativos na massa dos cachos com a aplicação de ácido giberélico, além de observarem uma redução no número médio de bagos por cachos.

Nas Tabelas 31 à 34 são apresentados os resultados das análises estatísticas para os parâmetros avaliados nos engaços da cultivar Vênus durante o ciclo vegetativo de 1999.

Tabela 30. Aplicação do Teste " $F$ " para as características mensuradas nos engaços da cultivar Vênus durante o ciclo vegetativo de 1999.

\begin{tabular}{lclcc}
\hline $\begin{array}{l}\text { Causas da } \\
\text { Variação }\end{array}$ & $\begin{array}{l}\text { Comprimento dos } \\
\text { engaços }(\mathrm{cm})\end{array}$ & $\begin{array}{l}\text { Largura dos } \\
\text { engaços }(\mathrm{cm}) \\
\text { Teste "F"' }\end{array}$ & $\begin{array}{l}\text { Massa dos } \\
\text { engaços }(\mathrm{g})\end{array}$ & $\begin{array}{l}\text { Diâmetro dos } \\
\text { pedicelos }(\mathrm{mm})\end{array}$ \\
\hline Técnicas & $34,647^{* *(3)}$ & $0,823 \mathrm{~ns}$ & $1,985 \mathrm{~ns}$ & $13,727^{* *}$ \\
Doses de GA3 & $2,109 \mathrm{~ns}^{(1)}$ & $1,279 \mathrm{~ns}$ & $5,347 * *$ & $1,788 \mathrm{~ns}$ \\
Interação & $2,812^{* *}$ & $1,952^{* 2)}$ & $2,939 * *$ & $2,307 * *$ \\
Técnicas x GA3 & & & & \\
\hline
\end{tabular}

${ }^{(1)}$ Não significativo ao nível de $5 \%$ de probabilidade.

${ }^{(2)}$ Significativo ao nível de $5 \%$ de probabilidade.

${ }^{(3)}$ Significativo ao nível de $1 \%$ de probabilidade.

Para todas as características avaliadas nos engaços, comprimento, largura e massa dos mesmos, assim como, o diâmetro dos pedicelos, o efeito da interação entre os fatores foi significativo (Tabela 30). 
Tabela 31. Aplicação do teste de Tukey e de regressão polinomial para o comprimento médio dos engaços da cultivar Vênus durante o ciclo vegetativo de 1999.

\begin{tabular}{|c|c|c|c|c|}
\hline Caus as da variação & \multicolumn{4}{|c|}{ Teste de Tukey para as médias das técnicas dentro das doses de GA3 } \\
\hline Doses de GA3 & Técnica 1 & Técnica 2 & Técnica 3 & Técnica 4 \\
\hline Oppm & $15,610 \mathrm{a} \mathrm{AB}^{(1)}$ & 16,555 a $\mathrm{A}$ & $13,350 \mathrm{~b} \mathrm{BC}$ & $13,195 \mathrm{~b} \mathrm{C}$ \\
\hline 10,0ppm & $13,360 \mathrm{~b} \mathrm{~B}$ & 16,290 a $\mathrm{A}$ & $14,870 \mathrm{ab} \mathrm{AB}$ & $14,895 \mathrm{ab} \mathrm{AB}$ \\
\hline 22,5ppm & $15,305 \mathrm{ab} \mathrm{A}$ & 16,175 a $\mathrm{A}$ & $12,825 \mathrm{c} \mathrm{B}$ & $13,910 \mathrm{bc} A B$ \\
\hline 35,0ppm & 14,470 bc $\mathrm{AB}$ & 16,690 a $\mathrm{A}$ & $12,880 \mathrm{c} \mathrm{B}$ & $14,928 \mathrm{ab} \mathrm{AB}$ \\
\hline 47,5ppm & 15,700 a $\mathrm{A}$ & 16,670 a $\mathrm{A}$ & $13,295 \mathrm{~b} \mathrm{~B}$ & $12,600 \mathrm{~b} \mathrm{~B}$ \\
\hline $60,0 \mathrm{ppm}$ & 16,200 a $\mathrm{A}$ & 16,880 a $\mathrm{A}$ & 14,395 b B & $15,175 \mathrm{ab} A B$ \\
\hline \multirow[t]{3}{*}{ 72,5ppm } & 15,665 a $\mathrm{A}$ & 14,965 a $\mathrm{A}$ & 14,380 a $\mathrm{A}$ & 13,755 a $\mathrm{A}$ \\
\hline & \multicolumn{4}{|c|}{$\begin{array}{c}\text { Regressão Polinomial para as doses de Ácido Giberélico dentro dos } \\
\text { níveis do fator técnicas }\end{array}$} \\
\hline & Técnica 1 & Técnica 2 & Técnica 3 & Técnica 4 \\
\hline Efeito Linear & $5,306^{(3)}$ & $1,232 \mathrm{~ns}$ & $0,854 \mathrm{~ns}$ & $0,076 \mathrm{~ns}$ \\
\hline Efeito Quadrático & $0,774 \mathrm{~ns}^{(2)}$ & $2,736 \mathrm{~ns}$ & $3,771 \mathrm{~ns}$ & $0,634 \mathrm{~ns}$ \\
\hline
\end{tabular}

${ }^{(1)}$ Médias dentro de uma linha seguidas de uma mesma letra minúscula ou maiúscula não diferem significativamente ao nível de $5 \%$ e $1 \%$ de probabilidade, respectivamente.

(2) Não significativo ao nível de $5 \%$ de probabilidade.

${ }^{(3)}$ Significativo ao nível de $5 \%$ de probabilidade.

Analisando a Tabela 31 e a Figura 36, nota-se efeito significativo do regulador vegetal sobre o comprimento médio dos engaços quando este foi aplicado isoladamente, tendendo a valores maiores com o aumento das doses. Os maiores comprimentos foram obtidos com as doses 60; 47,5 e 72,5ppm, os quais foram: 16,2cm, 15,7cm e 15,66 cm.

Já, com relação às diferentes técnicas, assim como observado para o comprimento médio dos cachos, menores comprimentos de engaços foram obtidos quando as diferentes doses do regulador vegetal foram aplicadas conjuntamente com o desponte de cachos realizado isoladamente ou em conjunto com o anelamento de ramos. 


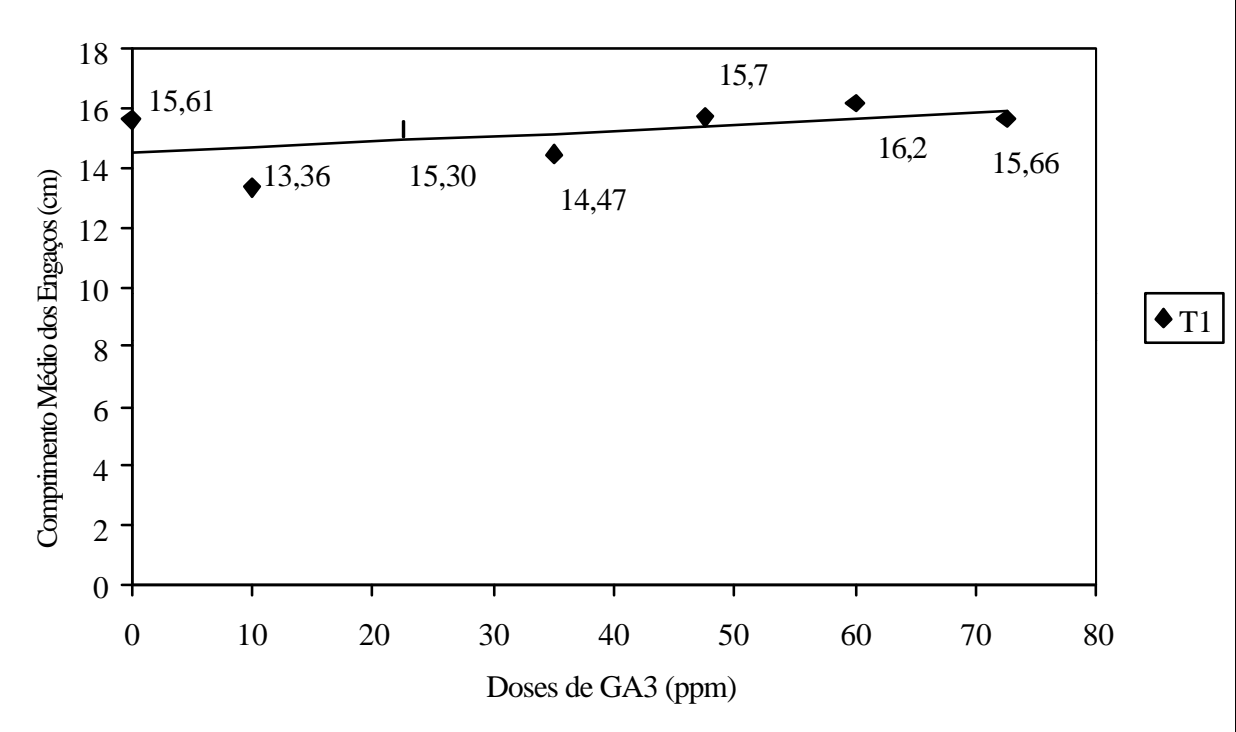

Figura 36 - Efeito da aplicação de diferentes doses de ácido giberélico, realizada isoladamente (sem a prática do anelamento de ramos e/ou desponte de cachos), sobre o comprimento médio dos engaços da cultivar Vênus, durante o ciclo vegetativo de 1999.

Tabela 32. Aplicação do teste de Tukey e de regressão polinomial para a largura média dos engaços da cultivar Vênus durante o ciclo vegetativo de 1999.

\begin{tabular}{lllll}
\hline Causas da variação & \multicolumn{4}{l}{ Teste de Tukey para as médias das técnicas dentro das doses de GA3 } \\
\hline Doses de GA3 & Técnica & Técnica 2 & Técnica 3 & Técnica 4 \\
Oppm & 8,245 a A & 6,700 a A & 8,180 a A & 6,665 a A \\
10,0ppm & 6,050 b A & 6,940 b A & 8,515 a A & 7,785 ab A \\
22,5ppm & 6,635 a A & 6,595 a A & 8,355 a A & 6,925 a A \\
35,0ppm & 7,560 a A & 7,390 a A & 6,550 a A & 7,360 a A \\
47,5ppm & 7,265 a A & 7,500 a A & 6,485 a A & 6,015 a A \\
60,0ppm & 7,170 a A & 6,835 a A & 6,605 a A & 8,140 a A \\
72,5ppm & 6,125 a A & 6,540 a A & 6,855 a A & 6,635 a A
\end{tabular}

Regressão Polinomial para as doses de Ácido Giberélico dentro dos

$\begin{array}{lllcl} & \text { Técnica 1 } & \text { Técnica 2 } & \text { Técnica 3 } & \text { Técnica 4 } \\ \text { Efeito Linear } & 1,280 \mathrm{~ns}^{(2)} & 0,003 \mathrm{~ns} & 10,996^{* *(3)} & 0,017 \mathrm{~ns} \\ \text { Efeito Quadrático } & 0,046 \mathrm{~ns} & 1,311 \mathrm{~ns} & 1,132 \mathrm{~ns} & 0,067 \mathrm{~ns}\end{array}$

(1) Médias dentro de uma linha seguidas de uma mesma letra minúscula ou maiúscula não diferem significativamente ao nível de $5 \%$ e $1 \%$ de probabilidade, respectivamente.

(2) Não significativo ao nível de $5 \%$ de probabilidade.

${ }^{(3)}$ Significativo ao nível de $1 \%$ de probabilidade. 


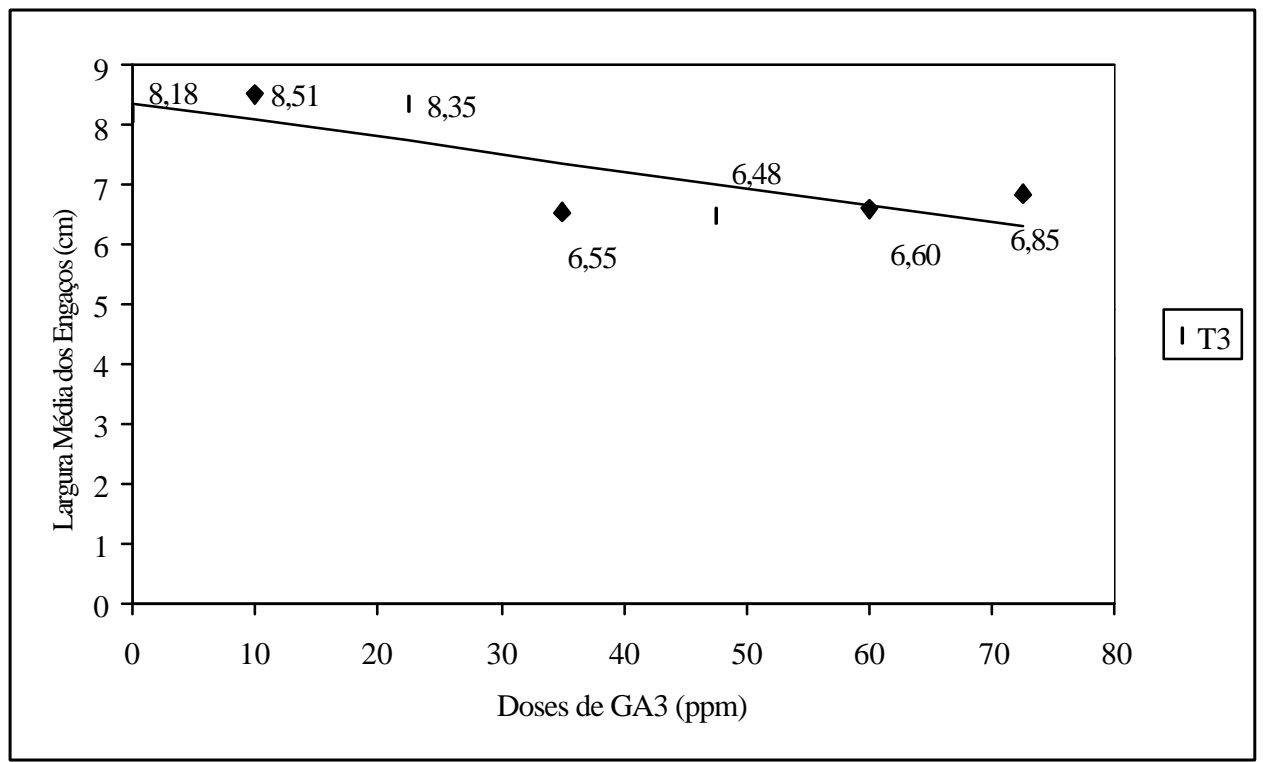

Figura 37 - Efeito da aplicação de diferentes doses de ácido giberélico, realizada juntamente com a prática do desponte de cachos, sobre a largura média dos engaços da cultivar Vênus, durante o ciclo vegetativo de 1999.

Com relação à largura dos engaços, houve efeito significativo da aplicação do regulador vegetal apenas quando este foi aplicado conjuntamente com a técnica de desponte de cachos (Tabela 32), notando-se valores menores com o aumento das doses de ácido giberélico (Figura 37). 
Tabela 33. Aplicação do teste de Tukey e de regressão polinomial para a massa média dos engaços da cultivar Vênus durante o ciclo vegetativo de 1999.

\begin{tabular}{|c|c|c|c|c|}
\hline Causas da variação & \multicolumn{4}{|c|}{ Teste de Tukey para as médias das técnicas dentro das doses de GA3 } \\
\hline Doses de GA3 & Técnica 1 & Técnica 2 & Técnica 3 & Técnica 4 \\
\hline 0ppm & 5,070 a $\mathrm{A}^{(1)}$ & $4,630 \mathrm{ab} A$ & $3,790 \mathrm{~b} \mathrm{~A}$ & $3,880 \mathrm{ab} A$ \\
\hline 10,0ppm & $3,055 \mathrm{~b} \mathrm{~B}$ & $3,960 \mathrm{ab} A B$ & $3,960 \mathrm{ab} \mathrm{AB}$ & 5,135 a $\mathrm{A}$ \\
\hline 22,5ppm & 3,245 a $\mathrm{A}$ & 3,240 a $\mathrm{A}$ & 3,740 a $\mathrm{A}$ & 3,530 a $\mathrm{A}$ \\
\hline 35,0ppm & 3,805 a $\mathrm{A}$ & 4,195 a $\mathrm{A}$ & 3,405 a $\mathrm{A}$ & 4,240 a $\mathrm{A}$ \\
\hline 47,5ppm & 3,575 a $\mathrm{A}$ & 3,615 a $\mathrm{A}$ & 3,580 a $\mathrm{A}$ & 2,855 a $\mathrm{A}$ \\
\hline $60,0 \mathrm{ppm}$ & $3,750 \mathrm{~b} \mathrm{~A}$ & 3,955 b A & 3,895 b A & 5,225 a $\mathrm{A}$ \\
\hline \multirow[t]{3}{*}{ 72,5ppm } & 2,770 a $\mathrm{A}$ & 3,820 a $\mathrm{A}$ & 4,005 a $A$ & 3,290 a $\mathrm{A}$ \\
\hline & \multicolumn{4}{|c|}{$\begin{array}{l}\text { Regressão Polinomial para as doses de Ácido Giberélico dentro dos } \\
\text { níveis do fator técnicas }\end{array}$} \\
\hline & Técnica 1 & Técnica 2 & Técnica 3 & Técnica 4 \\
\hline Efeito Linear & $7,837 * *(3)$ & $1,212 \mathrm{~ns}$ & $0,042 \mathrm{~ns}$ & $1,725 \mathrm{~ns}$ \\
\hline Efeito Quadrático & $0,820 \mathrm{~ns}^{(2)}$ & $2,321 \mathrm{~ns}$ & $1,325 \mathrm{~ns}$ & $0,008 \mathrm{~ns}$ \\
\hline
\end{tabular}

${ }^{(1)}$ Médias dentro de uma linha seguidas de uma mesma letra minúscula ou maiúscula não diferem significativamente ao nível de $5 \%$ e $1 \%$ de probabilidade, respectivamente.

(2) Não significativo ao nível de $5 \%$ de probabilidade.

${ }^{(3)}$ Significativo ao nível de $1 \%$ de probabilidade.

Já, a massa média dos engaços foi afetada significativamente pelas doses do regulador vegetal quando aplicadas isoladamente (Tabela 33), havendo diminuição na massa com o aumento das doses (Figura 38). Na Tabela 33 vale notar que o ácido giberélico quando aplicado na dose de 60ppm conjuntamente com o anelamento e desponte, proporcionou maior valor significativamente para a massa dos engaços. 


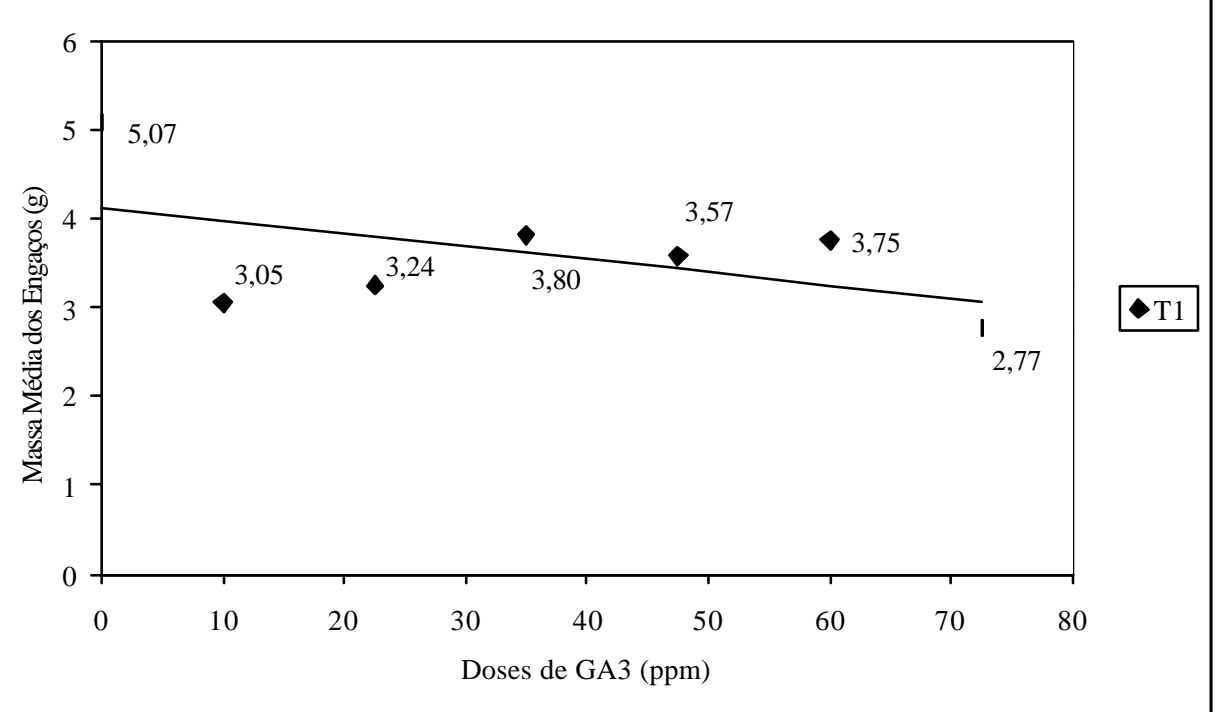

Figura 38 - Efeito da aplicação de diferentes doses de ácido giberélico, realizada isoladamente (sem a prática do anelamento de ramos e/ou desponte de cachos), sobre a massa média dos engaços da cultivar Vênus, durante o ciclo vegetativo de 1999.

Tabela 34. Aplicação do teste de Tukey e de regressão polinomial para o diâmetro médio dos pedicelos da cultivar Vênus durante o ciclo vegetativo de 1999.

\begin{tabular}{|c|c|c|c|c|}
\hline Causas da variação & \multicolumn{4}{|c|}{ Teste de Tukey para as médias das técnicas dentro das doses de GA3 } \\
\hline Doses de GA3 & Técnica 1 & Técnica 2 & Técnica 3 & Técnica 4 \\
\hline Oppm & 2,944 c C $^{(1)}$ & $3,186 \mathrm{ab} \mathrm{AB}$ & $3,009 \mathrm{bc} \mathrm{BC}$ & 3,322 a $\mathrm{A}$ \\
\hline 10,0ppm & 2,927 b B & $3,094 \mathrm{ab} A B$ & 3,235 a $\mathrm{A}$ & 3,241 a $\mathrm{A}$ \\
\hline 22,5ppm & 2,995 a A & 3,021 a $A$ & 3,056 a $\mathrm{A}$ & 3,109 a $\mathrm{A}$ \\
\hline $35.0 \mathrm{ppm}$ & 3,008 a $\mathrm{A}$ & 3,150 a $\mathrm{A}$ & 3,078 a $\mathrm{A}$ & 3,149 a $\mathrm{A}$ \\
\hline 47,5ppm & 3,055 a A & 3,096 a $\mathrm{A}$ & 3,059 a $\mathrm{A}$ & 3,071 a $\mathrm{A}$ \\
\hline $60,0 \mathrm{ppm}$ & 3,144 a A & 3,166 a $\mathrm{A}$ & 3,118 a $\mathrm{A}$ & 3,133 a $\mathrm{A}$ \\
\hline \multirow[t]{3}{*}{ 72,5ppm } & 2,979 b A & $3,156 \mathrm{ab} A$ & $3,147 \mathrm{ab} A$ & 3,185 a $\mathrm{A}$ \\
\hline & \multicolumn{4}{|c|}{$\begin{array}{l}\text { Regressão Polinomial para as doses de Ácido Giberélico dentro dos } \\
\text { níveis do fator técnicas }\end{array}$} \\
\hline & Técnica 1 & Técnica 2 & Técnica 3 & Técnica 4 \\
\hline Efeito Linear & $5,223 *^{(3)}$ & $0,305 \mathrm{~ns}$ & $0,402 \mathrm{~ns}$ & $6,111 *$ \\
\hline Efeito Quadrático & $1,907 \mathrm{~ns}^{(2)}$ & $2,471 \mathrm{~ns}$ & $0,238 \mathrm{~ns}$ & $9,764 * *(4)$ \\
\hline $\begin{array}{l}\text { (1) Médias dentro de } \\
\text { significativamente a } \\
\text { (2) Não significativo ao } \\
\text { (3) Significativo ao nível } \\
\text { (4) Significativo ao níve }\end{array}$ & $\begin{array}{l}\text { na linha segu } \\
\text { nível de 5\% } \\
\text { vel de } 5 \% \text { de } \\
\text { e } 5 \% \text { de prob }\end{array}$ & $\begin{array}{l}\text { e uma mesma } \\
\text { e probabilidade, } \\
\text { ilidade. } \\
\text { de. }\end{array}$ & $\begin{array}{l}\text { minúscula or } \\
\text { ectivamente. }\end{array}$ & lúscula não diferem \\
\hline
\end{tabular}




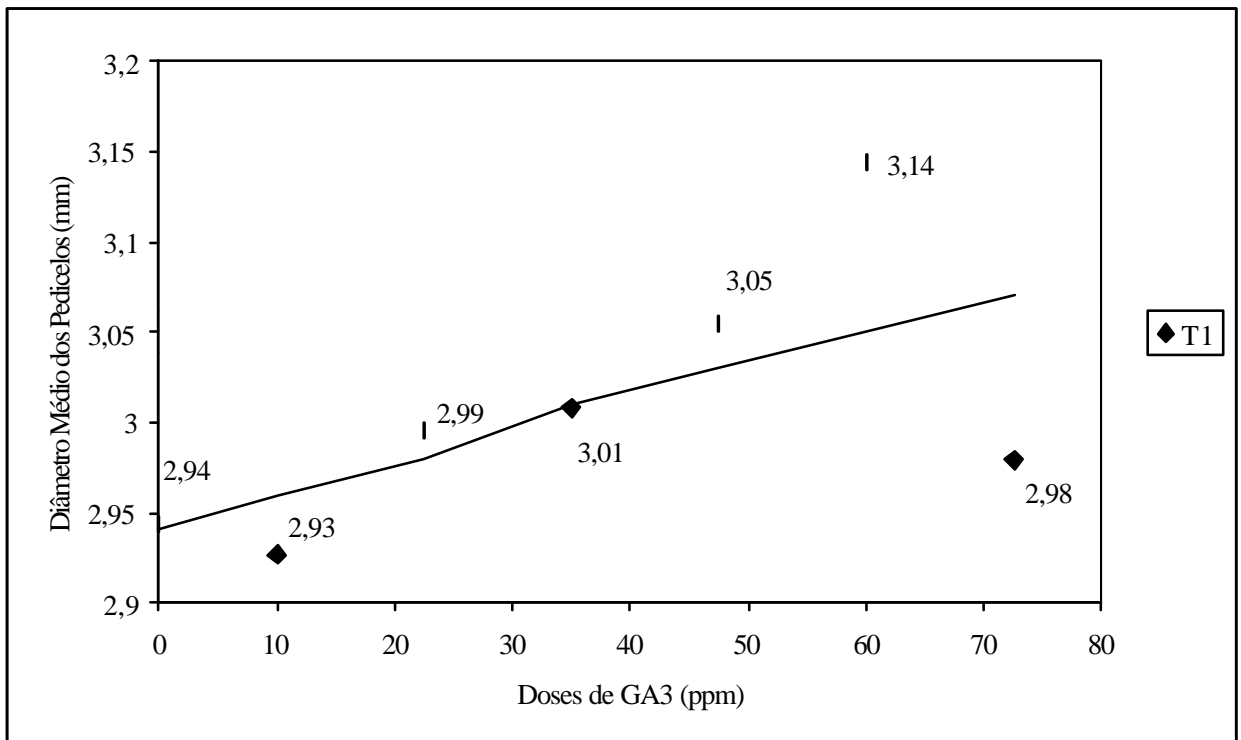

Figura 39 - Efeito da aplicação de diferentes doses de ácido giberélico, realizada isoladamente (sem a prática do anelamento de ramos e/ou desponte de cachos), sobre o diâmetro médio dos pedicelos da cultivar Vênus, durante o ciclo vegetativo de 1999.

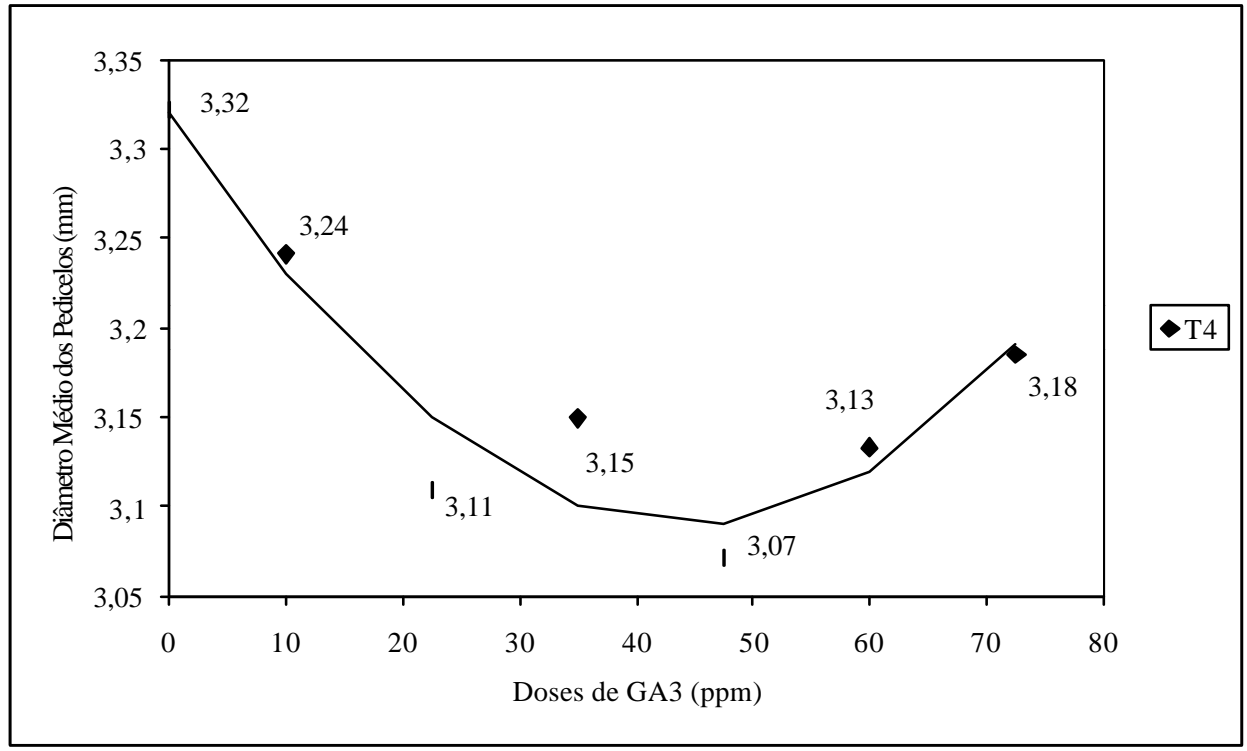

Figura 40 - Efeito da aplicação de diferentes doses de ácido giberélico, realizada juntamente com a prática do anelamento de ramos e do desponte de cachos, sobre o diâmetro médio dos pedicelos da cultivar Vênus, durante o ciclo vegetativo de 1999 . 
O diâmetro médio dos pedicelos também foi afetado significativamente pelo ácido giberélico quando aplicado isoladamente ou juntamente com o anelamento e desponte. Nota-se um engrossamento dos pedicelos com doses maiores do regulador vegetal aplicado isoladamente (Figura 39).

De acordo com experimentos realizados por Tomás Cooper et al. (1993), aplicações de ácido giberélico determinam um engrossamento e maior rigidez do pedicelo, sendo que, tal perda de flexibilidade, não permite que os bagos se acomodem ao serem submetidos às diferentes operações de manipulação do cacho na colheita e em pós-colheita, levando à queda de bagos. Neste experimento com a cultivar Vênus, notour se uma diminuição no número médio de bagos por cacho com o aumento das doses de ácido giberélico, isto pode ter ocorrido devido à queda de bagos durante a colheita e em pós-colheita, causada pelo engrossamento dos pedicelos.

Nas Tabelas 35 à 38 são apresentados os resultados das análises estatísticas para as características avaliadas nos bagos da cultivar Vênus durante o ciclo vegetativo de 1999.

Tabela 35. Aplicação do Teste "F" para as características mensuradas nos bagos da cultivar Vênus durante o ciclo vegetativo de 1999.

\begin{tabular}{|c|c|c|c|c|c|}
\hline $\begin{array}{l}\text { Causas da } \\
\text { Variação }\end{array}$ & $\begin{array}{l}\text { Comprimento } \\
\text { dos bagos } \\
(\mathrm{mm})\end{array}$ & $\begin{array}{l}\text { Largura de } \\
\text { bagos (mm) }\end{array}$ & $\begin{array}{l}\text { Massa média } \\
\text { bagos }(g) \\
\text { Teste “F”' }\end{array}$ & $\begin{array}{l}\text { Acidez } \\
\text { Titulável }\end{array}$ & $T S S^{(4)}\left({ }^{o}\right.$ Brix $)$ \\
\hline Técnicas & $61,973 * *$ & $35,356^{* *}$ & $63,157^{* *}$ & $1,883 \mathrm{~ns}$ & $3,541^{(2)}$ \\
\hline Doses de GA3 & $4,384 * *$ & $3,809 * *$ & $4,573 * *$ & $1,628 \mathrm{~ns}$ & $6,911 * *(3)$ \\
\hline $\begin{array}{l}\text { Interação } \\
\text { Técnicas x GA3 }\end{array}$ & $1,392 \mathrm{~ns}^{(1)}$ & $1,298 \mathrm{~ns}$ & $1,655 \mathrm{~ns}$ & $1,840 *$ & $1,512 \mathrm{~ns}$ \\
\hline $\begin{array}{l}\text { (1) Não significat } \\
{ }^{(2)} \text { Significativo a } \\
{ }^{(3)} \text { Significativo }\end{array}$ & $\begin{array}{l}\text { de } 5 \% \\
\% \text { de } \\
\% \text { de }\end{array}$ & $\begin{array}{l}\text { robabilidade. } \\
\text { bilidade. } \\
\text { bilidade. }\end{array}$ & & & \\
\hline
\end{tabular}

Na Tabela 36, nota-se que os efeitos das técnicas, assim como, das doses de ácido giberélico, sobre o comprimento, a largura e a massa de bagos, foram avaliados 
separadamente, uma vez que a interação entre os fatores não foi significativa para estas características (Tabela 35).

Tabela 36. Aplicação do teste de Tukey e de regressão polinomial para o comprimento médio, a largura média e a massa média dos bagos da cultivar Vênus durante o ciclo vegetativo de 1999.

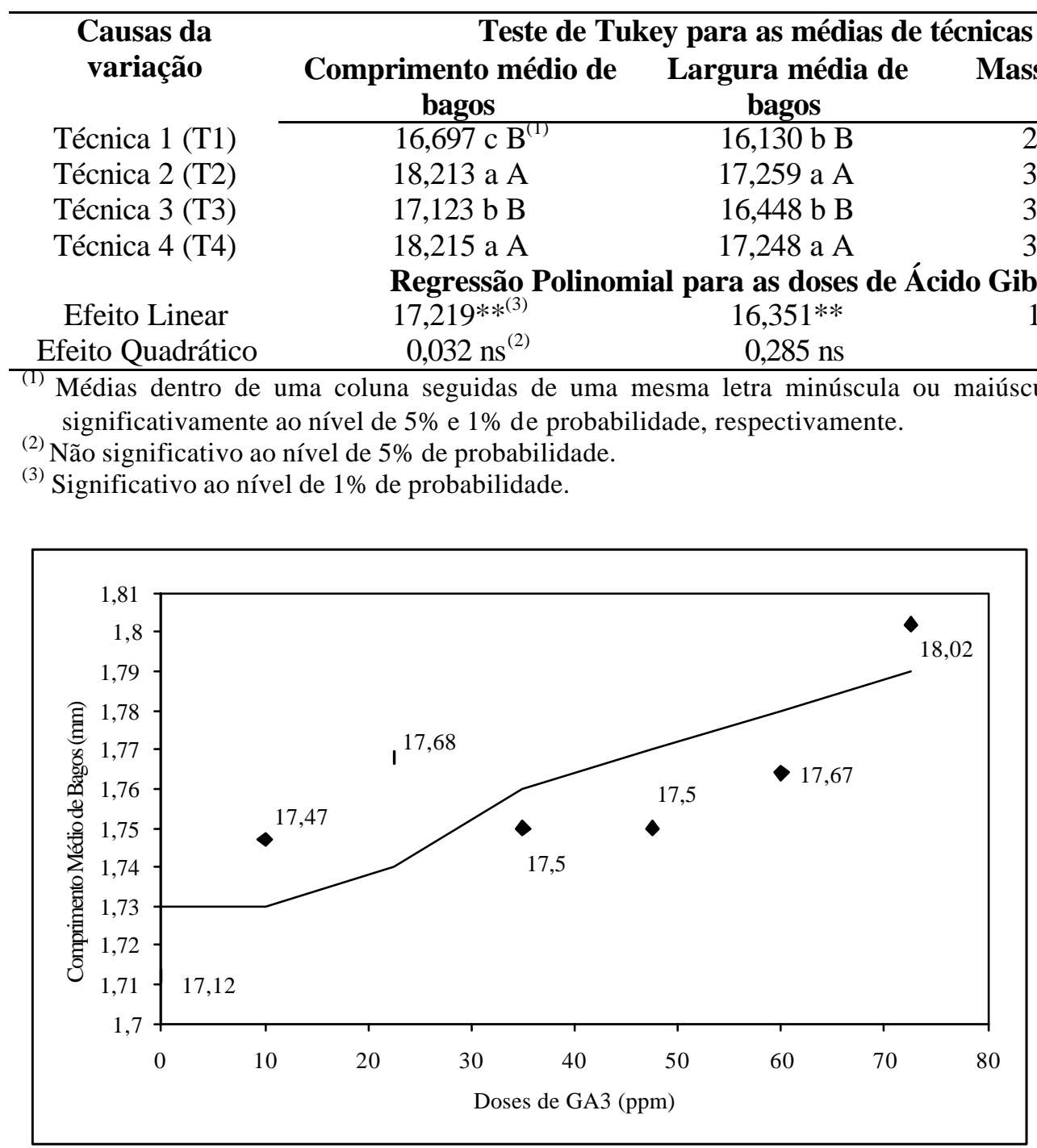

Figura 41 - Efeito de diferentes doses de ácido giberélico, sobre o comprimento médio dos bagos da cultivar Vênus, durante o ciclo vegetativo de 1999. 


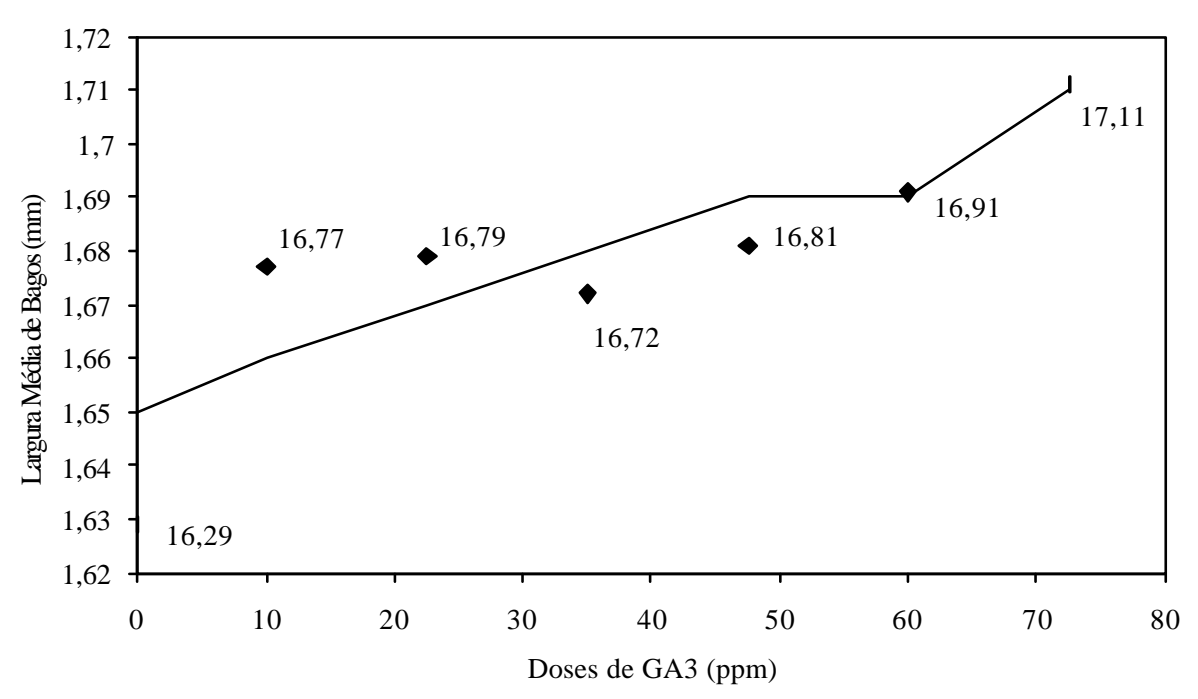

Figura 42 - Efeito de diferentes doses de ácido giberélico, sobre a largura média dos bagos da cultivar Vênus, durante o ciclo vegetativo de 1999.

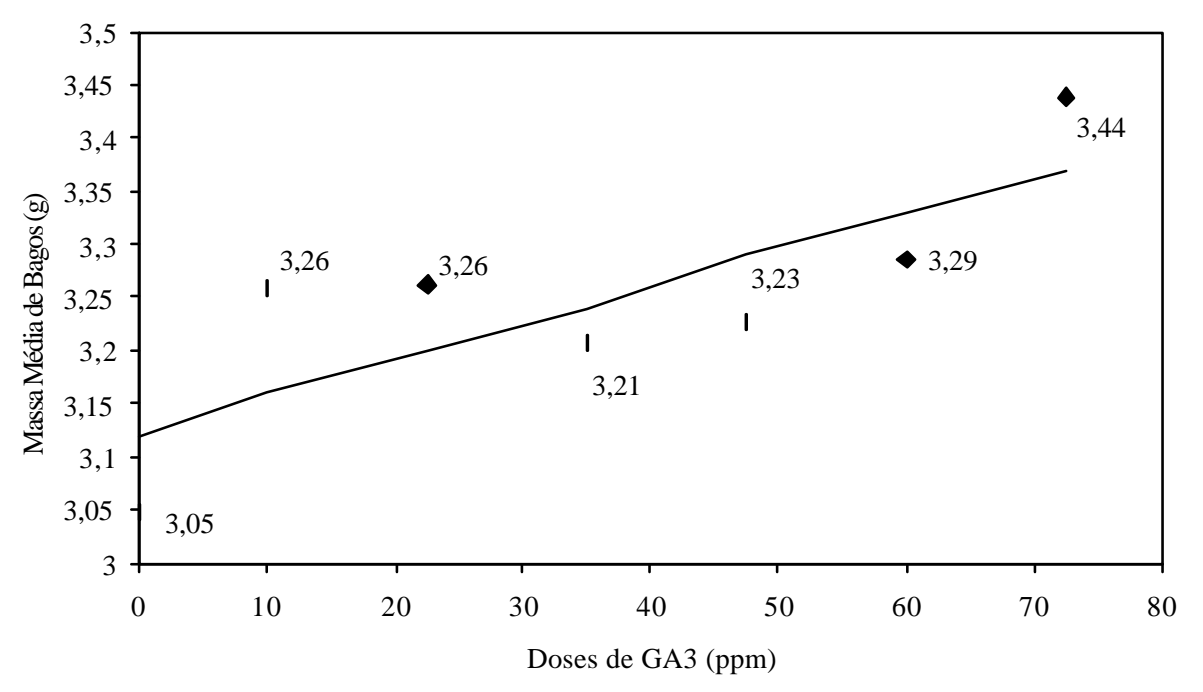

Figura 43 - Efeito de diferentes doses de ácido giberélico, sobre a massa média dos bagos da cultivar Vênus, durante o ciclo vegetativo de 1999.

O tamanho e a massa dos bagos foram maiores significativamente quando o anelamento de ramos foi realizado isoladamente ou em conjunto com o desponte de cachos (Tabela 36). Dados estes concordantes com Terra et al. (1998), que propõem 
aumento do tamanho dos bagos efetuando-se o anelamento duas ou três semanas após o pleno florescimento.

Também, notou-se efeito significativo da aplicação de acido giberélico sobre estas características, obtendo-se maiores valores com o aumento das doses do regulador, sendo a dose 72,5ppm a que mostrou os melhores resultados. Clark et al. (1993), também obtiveram aumento na massa dos bagos da cultivar Vênus com aplicações de 150 ou 300ppm de ácido giberélico em pré e em pós-florescimento. El-Hodairi \& Ibrahim (1995) verificaram efeito da aplicação de ácido giberélico sobre o comprimento de bagos da cultivar Sultanina, sendo maior com a aplicação de 50ppm antes do florescimento ou após a frutificação.

Devido a este aumento no tamanho e massa dos bagos com doses maiores de ácido giberélico, pode-se sugerir que novos experimentos sejam realizados com a cultivar Vênus, para se testar doses ainda maiores deste regulador de crescimento.

Com o exposto, pode-se concluir que o anelamento de ramos ou a aplicação de ácido giberélico são práticas interessantes para se aumentar o tamanho dos bagos da cultivar Vênus.

Além disso, embora o desponte de cachos promova uma redução no comprimento dos cachos e engaços, esta prática não interfere negativamente na massa dos cachos e dos bagos e no tamanho dos bagos.

Para a maioria das doses aplicadas, exceto 47,5ppm, não se notou efeito significativo das técnicas sobre a acidez titulável (Tabela 37). Já, observou-se efeito significativo de doses de ácido giberélico quando a prática do anelamento foi realizada conjuntamente, havendo uma tendência de aumento na acidez com doses intermediárias, sendo 0,689 e 0,781g de ácido tartárico/100ml os maiores valores encontrados com as doses de 35 e 47,5ppm, respectivamente (Figura 44). As doses 72,5 e 0ppm proporcionaram os menores valores de acidez do mosto, 0,627 e 0,634g de ácido tartárico/100ml, respectivamente. 
Tabela 37. Aplicação do teste de Tukey e de regressão polinomial para a acidez titulável da cultivar Vênus durante o ciclo vegetativo de 1999.

\begin{tabular}{|c|c|c|c|c|}
\hline Causas da variação & \multicolumn{4}{|c|}{ Teste de Tukey para as médias das técnicas dentro das doses de GA3 } \\
\hline Doses de GA3 & Técnica 1 & Técnica 2 & Técnica 3 & Técnica 4 \\
\hline Oppm & 0,718 a $A^{(1)}$ & 0,634 a $\mathrm{A}$ & 0,645 a $\mathrm{A}$ & 0,679 a $\mathrm{A}$ \\
\hline 10,0ppm & 0,697 a $\mathrm{A}$ & 0,664 a $\mathrm{A}$ & 0,699 a $\mathrm{A}$ & 0,702 a $\mathrm{A}$ \\
\hline $22,5 \mathrm{ppm}$ & 0,649 a $\mathrm{A}$ & 0,663 a $A$ & 0,694 a $\mathrm{A}$ & 0,711 a $\mathrm{A}$ \\
\hline 35,0ppm & 0,678 a $\mathrm{A}$ & 0,689 a $\mathrm{A}$ & 0,703 a $\mathrm{A}$ & 0,657 a $\mathrm{A}$ \\
\hline 47,5ppm & $0,682 \mathrm{ab} \mathrm{AB}$ & $0,723 \mathrm{ab} \mathrm{AB}$ & $0,629 \mathrm{~b} \mathrm{~B}$ & $0,723 \mathrm{ab} A B$ \\
\hline $60,0 \mathrm{ppm}$ & 0,735 a $\mathrm{A}$ & 0,654 a $\mathrm{A}$ & 0,637 a $\mathrm{A}$ & 0,718 a $\mathrm{A}$ \\
\hline 72,5ppm & 0,678 a $\mathrm{A}$ & 0,627 a $\mathrm{A}$ & 0,631 a $\mathrm{A}$ & 0,657 a $\mathrm{A}$ \\
\hline
\end{tabular}

Regressão Polinomial para as doses de Ácido Giberélico dentro dos

$\begin{array}{llcll} & \text { Técnica 1 } & \text { Técnica 2 } & \text { Técnica 3 } & \text { Técnica 4 } \\ \text { Efeito Linear } & 0,003 \mathrm{~ns}^{(2)} & 0,219 \mathrm{~ns} & 2,589 \mathrm{~ns} & 0,033 \mathrm{~ns} \\ \text { Efeito Quadrático } & 1,064 \mathrm{~ns} & 10,173 * *(3) & 2,162 \mathrm{~ns} & 0,945 \mathrm{~ns}\end{array}$

${ }^{(1)}$ Médias dentro de uma linha seguidas de uma mesma letra minúscula ou maiúscula não diferem significativamente ao nível de $5 \%$ e $1 \%$ de probabilidade, respectivamente.

(2) Não significativo ao nível de $5 \%$ de probabilidade.

${ }^{(3)}$ Significativo ao nível de $1 \%$ de probabilidade.

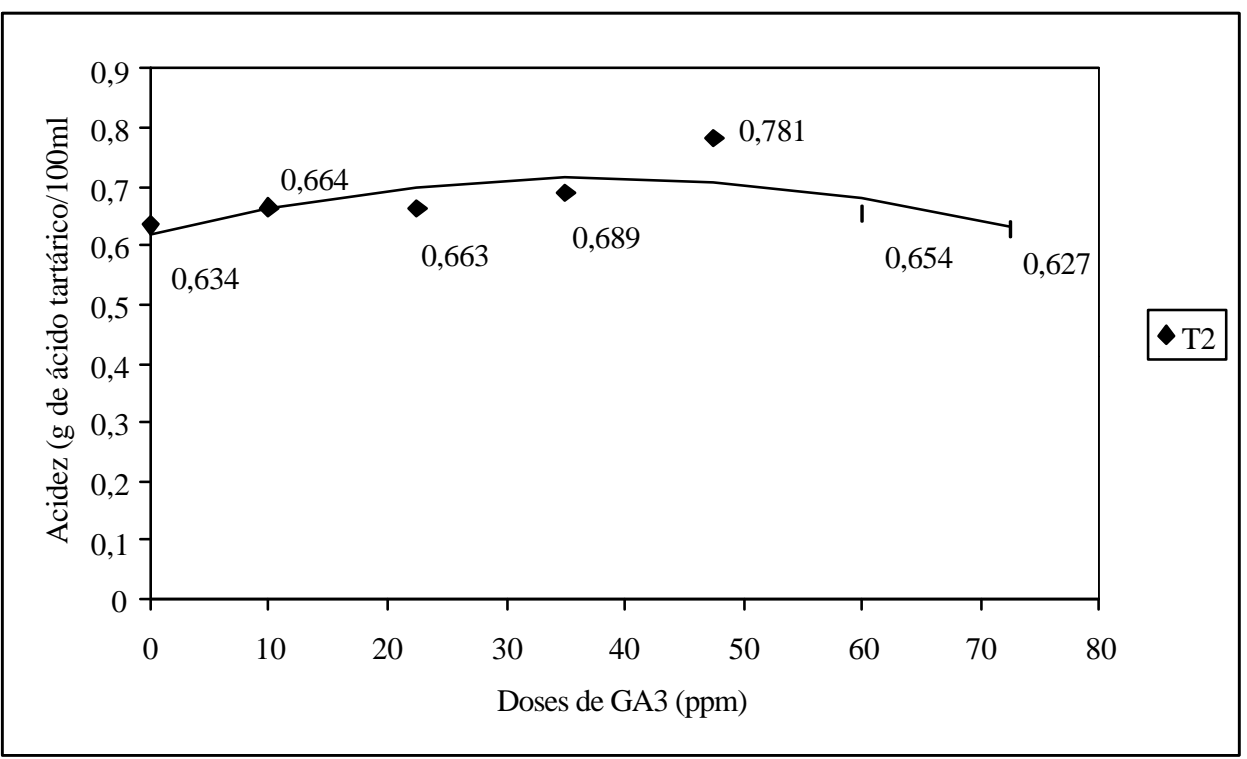

Figura 44 - Efeito da aplicação de diferentes doses de ácido giberélico, realizada juntamente com a prática do anelamento de ramos, sobre a acidez titulável dos bagos da cultivar Vênus, durante o ciclo vegetativo de 1999. 
Tabela 38. Aplicação do teste de Tukey e de regressão polinomial para o teor de sólidos solúveis da cultivar Vênus durante o ciclo vegetativo de 1999.

\begin{tabular}{|c|c|}
\hline Causas da variação & Teste de Tukey para as médias de técnicas \\
\hline Técnica 1 (T1) & $11,387 \mathrm{~b} \mathrm{~B}^{(1)}$ \\
\hline Técnica 2 (T2) & $11,891 \mathrm{ab} \mathrm{AB}$ \\
\hline Técnica 3 (T3) & $11,913 \mathrm{ab} \mathrm{AB}$ \\
\hline Técnica 4 (T4) & 12,473 a $\mathrm{A}$ \\
\hline Efeito Linear & $\begin{array}{c}\text { Regressão Polinomial para as doses de Ácido Giberélico } \\
7,327 *(2)\end{array}$ \\
\hline Efeito Quadrático & $20,567 * *$ \\
\hline
\end{tabular}

Através do teste de Tukey notou-se que o teor de sólidos solúveis totais, quando o anelamento e o desponte foram realizados conjuntamente, foi maior significativamente do que quando nenhuma das técnicas foi realizada, sendo os teores, respectivamente, $12,473^{\circ}$ Brix e $11,387^{\circ}$ Brix (Tabela 38).

Embora a diferença não tenha sido significativa, nota-se que o anelamento de ramos e o desponte de cachos realizados conjuntamente originaram maior teor de sólidos solúveis totais do que tais técnicas realizadas separadamente. Isto sugere que, a prática do desponte de cachos pode ter contribuído para uma melhor distribuição dos fotossintetizados entre bagos dos cachos. Também, sugere-se que o anelamento de ramos pode ter aumentado a concentração de açúcares nos bagos, proporcionando um incremento no teor de sólidos solúveis totais. Assim como observado por Pommer et al. (1991); Antonacci (1993) e Peruzzo (1994), o anelamento de ramos parece adiantar o processo de maturação dos frutos.

Também, na Tabela 38, verifica-se efeito isolado do ácido giberélico sobre o teor de sólidos solúve is totais do mosto. Na Figura 45, pode-se perceber que o maior teor $\left(13,44^{\circ}\right.$ Brix $)$ foi obtido quando não se aplicou o regulador vegetal. Já, a dose de $60 \mathrm{ppm}$ produziu o menor teor de sólidos solúveis totais do mosto, $11,005^{\circ}$ Brix.

Tais resultados sugerem que o ácido giberélico pode promover um atraso na maturação dos frutos quando aplicado quinze dias após o pleno florescimento. 


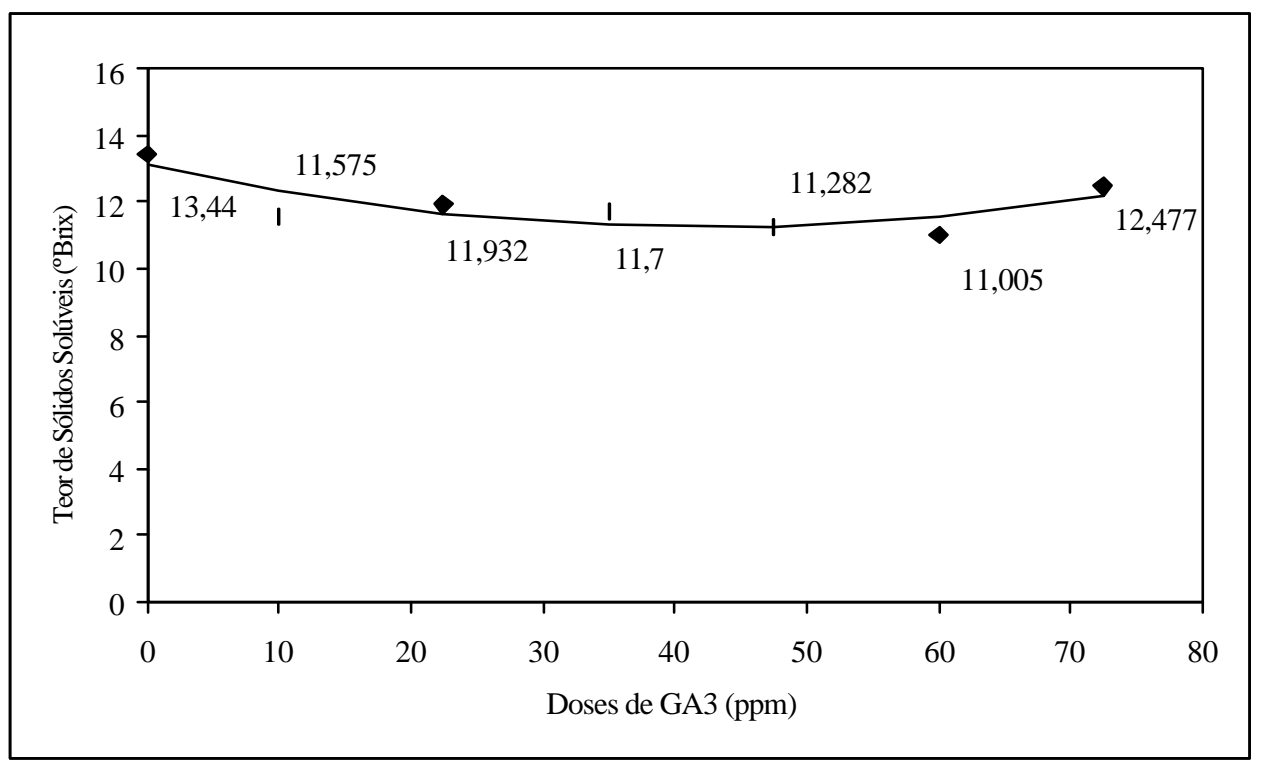

Figura 45 - Efeito de diferentes doses de ácido giberélico, sobre o teor de sólidos solúveis da cultivar Vênus, durante o ciclo vegetativo de 1999.

\subsubsection{Cultivar Vênus - Ciclo vegetativo de 2000}

Nas Tabelas 39 à 43 são apresentados os resultados das análises estatísticas para os parâmetros avaliados nos cachos da cultivar Vênus durante o ciclo vegetativo de 2000 .

Tabela 39. Aplicação do Teste "F" para as características mensuradas nos cachos da cultivar Vênus durante o ciclo vegetativo de 2000.

\begin{tabular}{lclcl}
\hline $\begin{array}{l}\text { Causas da } \\
\text { Variação }\end{array}$ & $\begin{array}{l}\text { Comprimento de } \\
\text { cachos }(\mathrm{cm})\end{array}$ & $\begin{array}{l}\text { Largura de } \\
\text { cachos }(\mathrm{cm})\end{array}$ & $\begin{array}{l}\text { Massa de cachos } \\
(\mathrm{g}) \\
\text { Teste “F” }\end{array}$ & $\begin{array}{l}\text { Número de } \\
\text { bagos/cacho }\end{array}$ \\
\hline Técnicas & $20,576^{* *}$ & $1,797 \mathrm{~ns}{ }^{(1)}$ & $1,726 \mathrm{~ns}$ & $4,650^{* *}$ \\
Doses de GA3 & $4,074^{* *}$ & $2,311^{*(2)}$ & $6,808^{* *(3)}$ & $3,638^{* *}$ \\
Interação & $4,679^{* *}$ & $1,502 \mathrm{~ns}$ & $1,971^{*}$ & $2,841^{* *}$ \\
Técnicas x GA3 & & & & \\
${ }^{(1)}$ Não significativo ao nível de 5\% de probabilidade. & & \\
${ }^{(2)}$ Significativo ao nível de 5\% de probabilidade. & & \\
${ }^{(3)}$ Significativo ao nível de 1\% de probabilidade. &
\end{tabular}


Na Tabela 39 nota-se que a interação entre os fatores foi significativa para todas as características mensuradas nos cachos, exceto para a largura média de cachos, que sofreu influência apenas de doses de ácido giberélico.

Mais uma vez verifica-se que dentro das diferentes doses de ácido giberélico, a prática do desponte de cachos, sendo realizada isoladamente ou em conjunto com o anelamento originou, na maioria dos casos menores comprimentos de cachos, embora nem todos tenham sido significativos (Tabela 40). Também notourse efeito da aplicação de ácido giberélico quando realizada isoladamente, ou em conjunto com o anelamento de ramos, ou com o desponte de cachos. Quando aplicou-se apenas o ácido giberélico, ou realizou-se também o desponte de cachos, notou-se uma tendência de aumento no comprimento médio dos cachos com o aumento das doses (Figuras 46 e 48). Já, quando aplicado conjuntamente com a prática do anelamento de ramos, maiores valores foram observados com as doses 0; 47,5 e 72,5ppm do regulador vegetal (Figura 47).

Tabela 40. Aplicação do teste de Tukey e de regressão polinomial para o comprimento médio dos cachos da cultivar Vênus durante o ciclo vegetativo de 2000.

\begin{tabular}{|c|c|c|c|c|}
\hline Causas da variação & \multicolumn{4}{|c|}{ Teste de Tukey para as médias das técnicas dentro das doses de GA3 } \\
\hline Doses de GA3 & Técnica 1 & Técnica 2 & Técnica 3 & Técnica 4 \\
\hline 0ppm & $17,213 \mathrm{a} \mathrm{A}^{(1)}$ & 18,565 a $\mathrm{A}$ & $14,070 \mathrm{~b} \mathrm{~B}$ & 17,625 a A \\
\hline $10,0 \mathrm{ppm}$ & 16,983 a $\mathrm{A}$ & 16,820 a $\mathrm{A}$ & 16,945 a A & 15,420 a $\mathrm{A}$ \\
\hline $22,5 \mathrm{ppm}$ & 19,545 a $\mathrm{A}$ & $15,287 \mathrm{~b} B$ & $16,052 \mathrm{~b}$ B & $15,240 \mathrm{~b} \mathrm{~B}$ \\
\hline 35,0ppm & $16,720 \mathrm{ab} A$ & 18,260 a $\mathrm{A}$ & $16,300 \mathrm{~b} \mathrm{~A}$ & $16,860 \mathrm{ab} A$ \\
\hline 47,5ppm & $18,200 \mathrm{ab} A$ & 18,373 a $\mathrm{A}$ & $16,965 \mathrm{ab} A$ & $16,555 \mathrm{~b} \mathrm{~A}$ \\
\hline 60,0ppm & 18,320 a $\mathrm{A}$ & $17,972 \mathrm{ab} A$ & 16,263 b A & $16,565 \mathrm{ab} A$ \\
\hline \multirow[t]{3}{*}{ 72,5ppm } & 18,815 a $\mathrm{A}$ & $18,363 \mathrm{ab} A$ & $17,425 \mathrm{ab} A$ & $16,865 \mathrm{~b} \mathrm{~A}$ \\
\hline & \multicolumn{4}{|c|}{$\begin{array}{c}\text { Regressão Polinomial para as doses de Ácido Giberélico dentro dos } \\
\text { níveis do fator técnicas }\end{array}$} \\
\hline & Técnica 1 & Técnica 2 & Técnica 3 & Técnica 4 \\
\hline Efeito Linear & $5,463 *$ & $3,764 \mathrm{~ns}$ & $12,837 * *(4)$ & $0,372 \mathrm{~ns}$ \\
\hline Efeito Quadrático & $0,0001 \mathrm{~ns}^{(2)}$ & $4,336^{*(3)}$ & $1,877 \mathrm{~ns}$ & $3,606 \mathrm{~ns}$ \\
\hline $\begin{array}{l}\text { (1) Médias dentro de } \\
\text { significativamente } \\
\text { (2) Não significativo ao } \\
\text { (3) Significativo ao nív } \\
\text { (4) Significativo ao níve }\end{array}$ & $\begin{array}{l}\text { linha segu } \\
\text { vel de } 5 \% \\
1 \text { de } 5 \% \text { de }\end{array}$ & $\begin{array}{l}\text { uma mesn } \\
\text { robabilidac } \\
\text { dade. }\end{array}$ & $\begin{array}{l}\text { ninúscula } \\
\text { ivamente. }\end{array}$ & scula não diferem \\
\hline
\end{tabular}




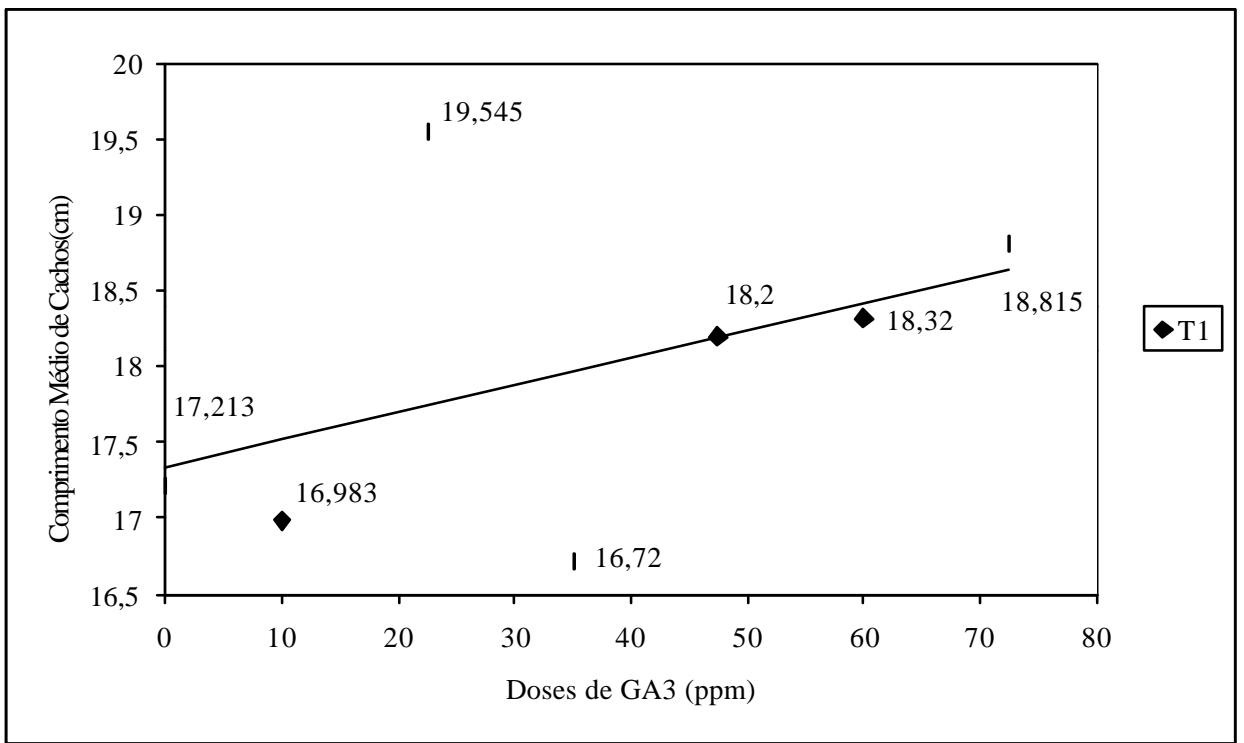

Figura 46 - Efeito da aplicação de diferentes doses de ácido giberélico, realizada isoladamente (sem a prática do anelamento de ramos e/ou desponte de cachos), sobre o comprimento médio de cachos da cultivar Vênus, durante o ciclo vegetativo de 2000.

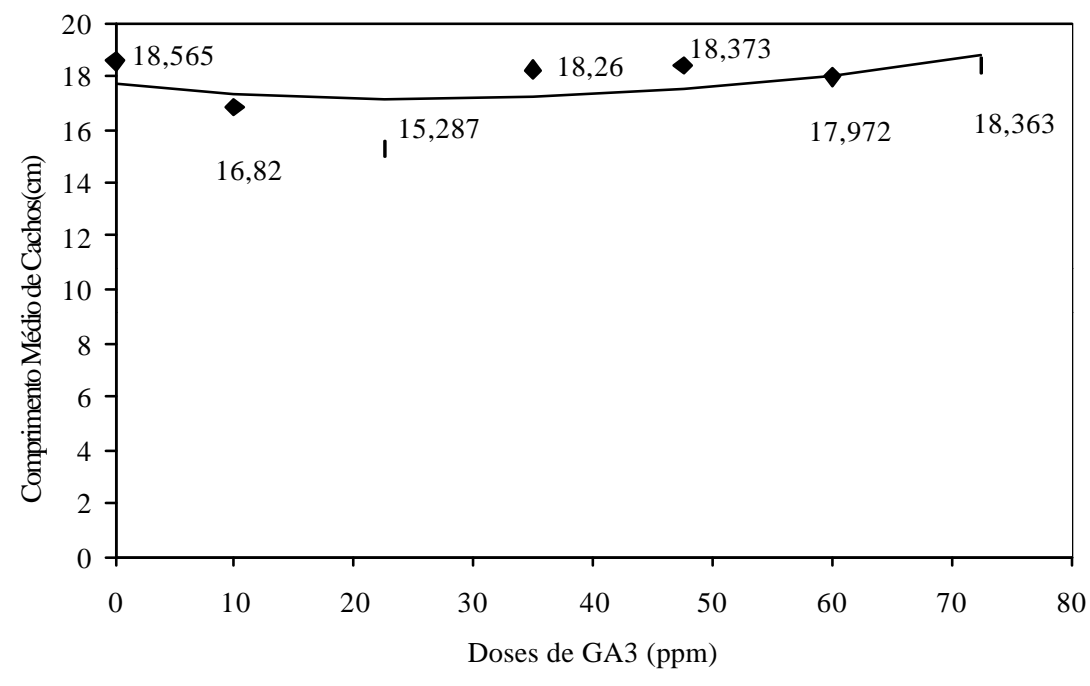

Figura 47 - Efeito da aplicação de diferentes doses de ácido giberélico, realizada juntamente com a prática do anelamento de ramos, sobre $\mathrm{o}$ comprimento médio dos cachos da cultivar Vênus, durante o ciclo vegetativo de 2000 . 


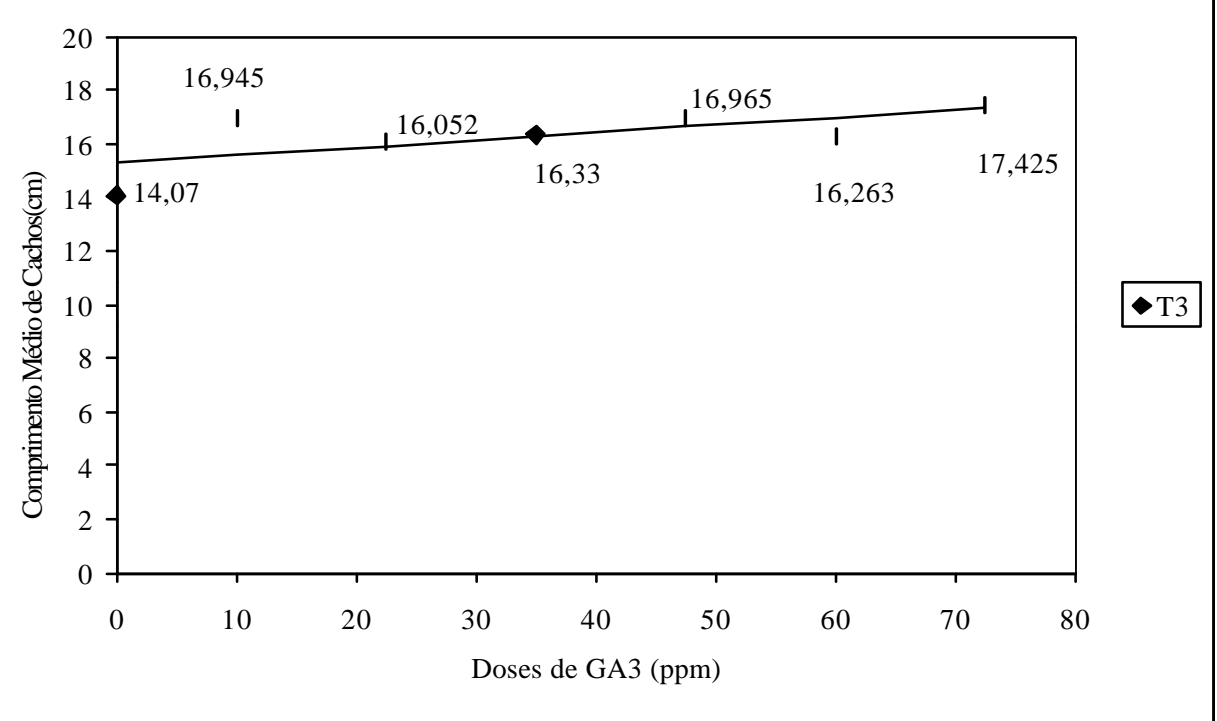

Figura 48 - Efeito da aplicação de diferentes doses de ácido giberélico, realizada juntamente com a prática do desponte de cachos, sobre o comprimento médio de cachos da cultivar Vênus, durante o ciclo vegetativo de 2000.

Tabela 41. Aplicação de regressão polinomial para a largura média de cachos da cultivar Vênus durante o ciclo vegetativo de 2000.

\begin{tabular}{cc}
\hline & Regressão Polinomial para as doses de Ácido Giberélico \\
\hline Efeito Linear & $8,998^{* *(2)}$ \\
Efeito Quadrático & $0,446 \mathrm{~ns}^{(1)}$ \\
\hline
\end{tabular}

(1) Não significativo ao nível de 5\% de probabilidade.

${ }^{(2)}$ Significativo ao nível de $1 \%$ de probabilidade.

Com referência à largura dos cachos, houve efeito isolado da aplicação de ácido giberélico (Tabela 41), notando-se aumento nesta característica com o aumento de doses do regulador vegetal (Figura 49). A maior largura média de cachos foi obtida com a dose $72,5 \mathrm{ppm}(12,832 \mathrm{~cm})$. No entanto, quando não se aplicou o ácido giberélico (0ppm) a largura média dos cachos foi de $11,742 \mathrm{~cm}$. 


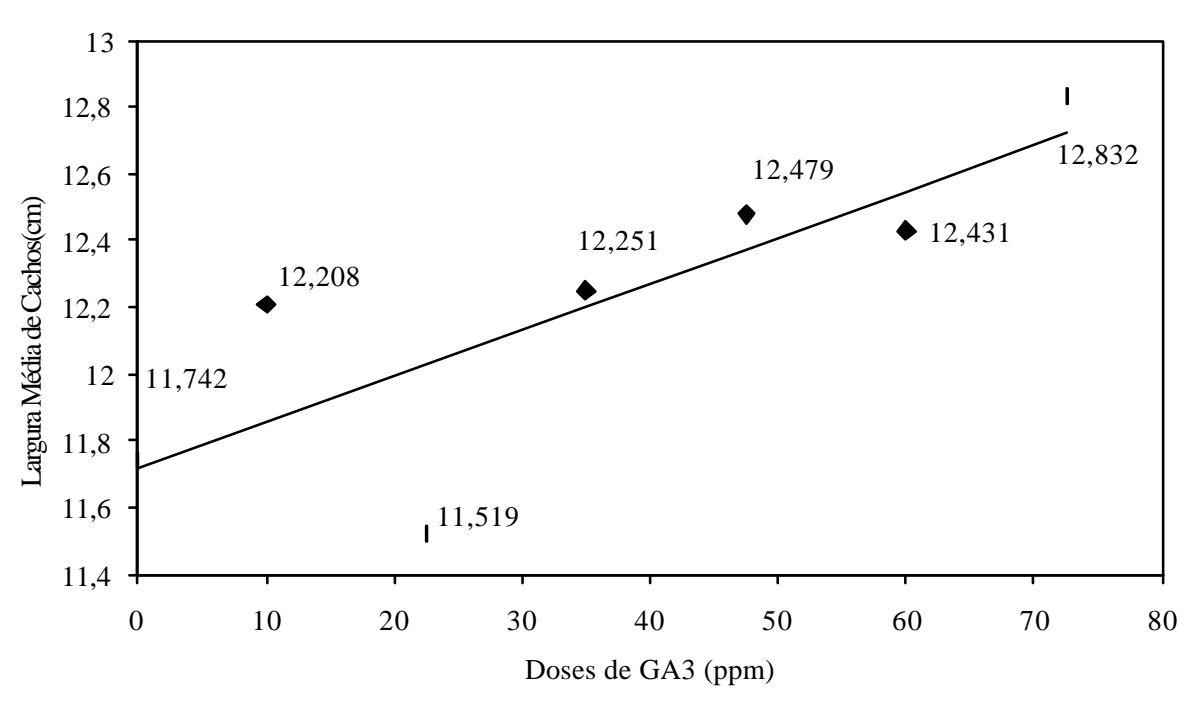

Figura 49 - Efeito de diferentes doses de ácido giberélico, sobre a largura média dos cachos da cultivar Vênus, durante o ciclo vegetativo de 2000 .

Tabela 42. Aplicação do teste de Tukey e de regressão polinomial para a massa média dos cachos da cultivar Vênus durante o ciclo vegetativo de 2000.

\begin{tabular}{|c|c|c|c|c|}
\hline Causas da variação & \multicolumn{4}{|c|}{ Teste de Tukey para as médias das técnicas dentro das doses de GA3 } \\
\hline Doses de GA3 & Técnica 1 & Técnica 2 & Técnica 3 & Técnica 4 \\
\hline Oppm & $374,244 \mathrm{a} \mathrm{A}^{(1)}$ & 419,629 a A & 309,057 a $\mathrm{A}$ & 385,340 a A \\
\hline $10,0 p p m$ & 389,233 a $A$ & 398,855 a $A$ & 514,897 a $\mathrm{A}$ & 393,285 a $A$ \\
\hline 22,5ppm & 434,600 a $\mathrm{A}$ & 399,405 a $\mathrm{A}$ & 430,183 a $A$ & 424,439 a $\mathrm{A}$ \\
\hline 35,0ppm & 388,050 b B & 565,388 a $\mathrm{A}$ & $449,980 \mathrm{ab} \mathrm{AB}$ & 548,656 a $\mathrm{AB}$ \\
\hline 47,5ppm & 442,285 a $\mathrm{A}$ & 560,948 a A & 494,838 a $\mathrm{A}$ & 479,965 a $\mathrm{A}$ \\
\hline $60,0 \mathrm{ppm}$ & 485,600 a $\mathrm{A}$ & 508,669 a $\mathrm{A}$ & 413,648 a $\mathrm{A}$ & 511,178 a $\mathrm{A}$ \\
\hline \multirow[t]{3}{*}{ 72,5ppm } & 504,535 a $\mathrm{A}$ & 486,706 a A & 565,026 a $\mathrm{A}$ & 464,250 a $\mathrm{A}$ \\
\hline & \multicolumn{4}{|c|}{$\begin{array}{c}\text { Regressão Polinomial para as doses de Ácido Giberélico dentro dos } \\
\text { níveis do fator técnicas }\end{array}$} \\
\hline & Técnica 1 & Técnica 2 & Técnica 3 & Técnica 4 \\
\hline Efeito Linear & $8,711 * *^{(4)}$ & $8,443 * *$ & $9,359 * *$ & $6,829 * *$ \\
\hline Efeito Quadrático & $0,325 \mathrm{~ns}^{(2)}$ & $3,851 *^{(3)}$ & $0,167 \mathrm{~ns}$ & $4,122^{*}$ \\
\hline
\end{tabular}

(1) Médias dentro de uma linha seguidas de uma mesma letra minúscula ou maiúscula não diferem significativamente ao nível de $5 \%$ e $1 \%$ de probabilidade, respectivamente.

(2) Não significativo ao nível de $5 \%$ de probabilidade.

${ }^{(3)}$ Significativo ao nível de 5\% de probabilidade.

${ }^{(4)}$ Significativo ao nível de $1 \%$ de probabilidade.

Efeitos significativos de doses de ácido giberélico sobre a massa média dos cachos foram observados quando o regulador foi aplicado isoladamente, ou 
conjuntamente com o anelamento de ramos e/ou com o desponte de cachos (Tabela 42). Quando foi aplicado somente o regulador vegetal ou fez-se também o desponte de cachos, maiores massas foram obtidas com doses mais elevadas (Figuras 50 e 52), sendo que a dose 72,5ppm gerou um incremento de 34,81\% qua ndo aplicada isoladamente, e de $82,82 \%$ quando aplicada conjuntamente com o desponte de cachos. No entanto, quando o ácido giberélico foi aplicado em conjunto com o anelamento de ramos, as doses de 35 e 47,5ppm originaram maiores massas, gerando incrementos de 34,73\% e $33,68 \%$, respectivamente (Figura 51). Por outro lado, quando conjuntamente com a aplicação do regulador realizaram-se as duas técnicas, a maior massa foi observada com a dose de 35ppm, a qual gerou um aumento de 42,38\% (Figura 53).

O efeito das técnicas, dentro de cada uma dessas doses, pode ser verificado através do teste de Tukey, sendo significativo apenas dentro da dose de 35ppm, podendo-se observar maiores valores quando o anelamento foi realizado sozinho ou conjuntamente com o desponte de cachos (Tabela 42).

Com isto nota-se que, quando o anelamento não foi realizado, doses maiores de ácido giberélico geraram os maiores incrementos. Enquanto que, quando tal técnica foi realizada, mesmo que em conjunto com o desponte de cachos, doses intermediárias originaram os maiores incrementos. Tal resultado sugere ser o anelamento de ramos uma prática interessante para aumentar a massa média de cachos da cultivar Vênus. 


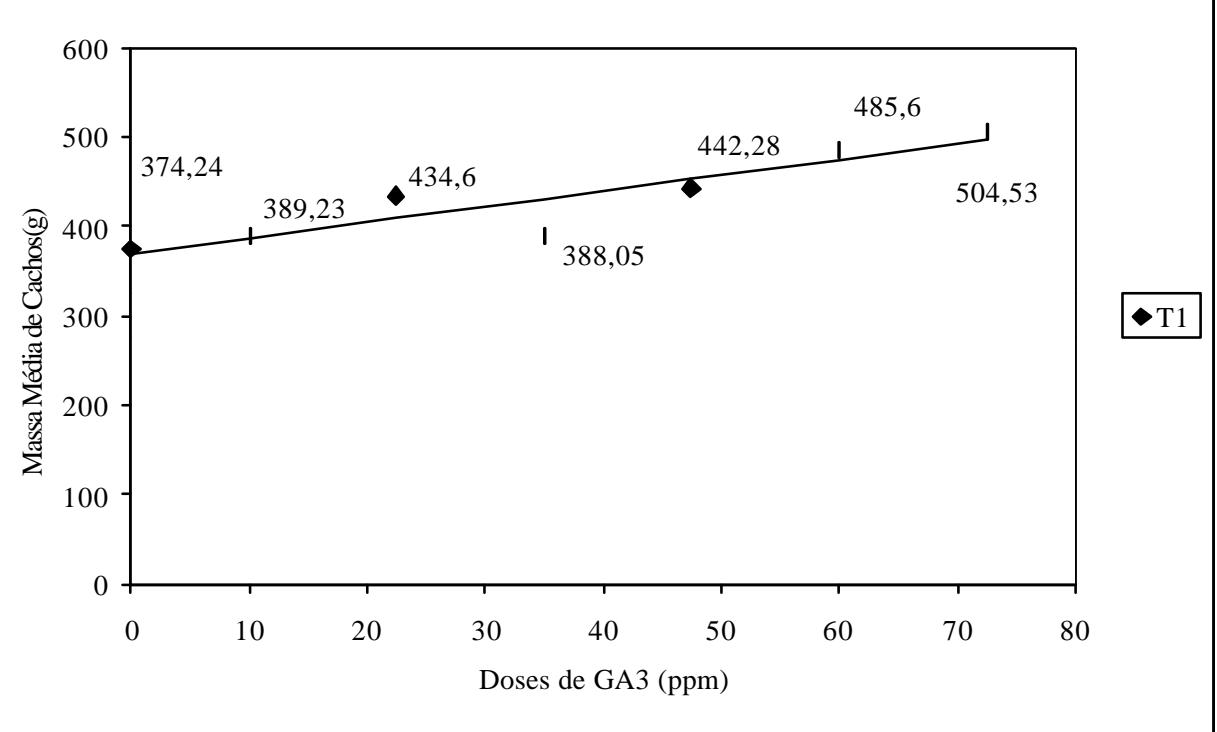

Figura 50 - Efeito da aplicação de diferentes doses de ácido giberélico, realizada isoladamente (sem a prática do anelamento de ramos e/ou desponte de cachos), sobre a massa média dos cachos da cultivar Vênus, durante o ciclo vegetativo de 2000 .

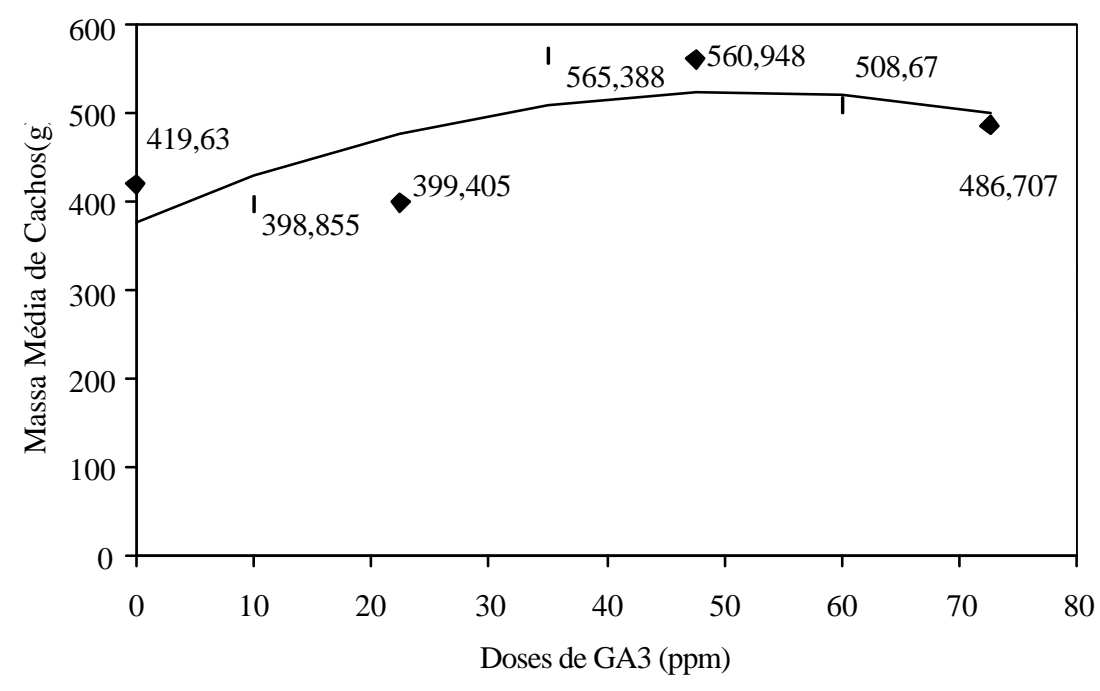

Figura 51 - Efeito da aplicação de diferentes doses de ácido giberélico, realizada juntamente com a prática do anelamento de ramos, sobre a massa média dos cachos da cultivar Vênus, durante o ciclo vegetativo de 2000. 


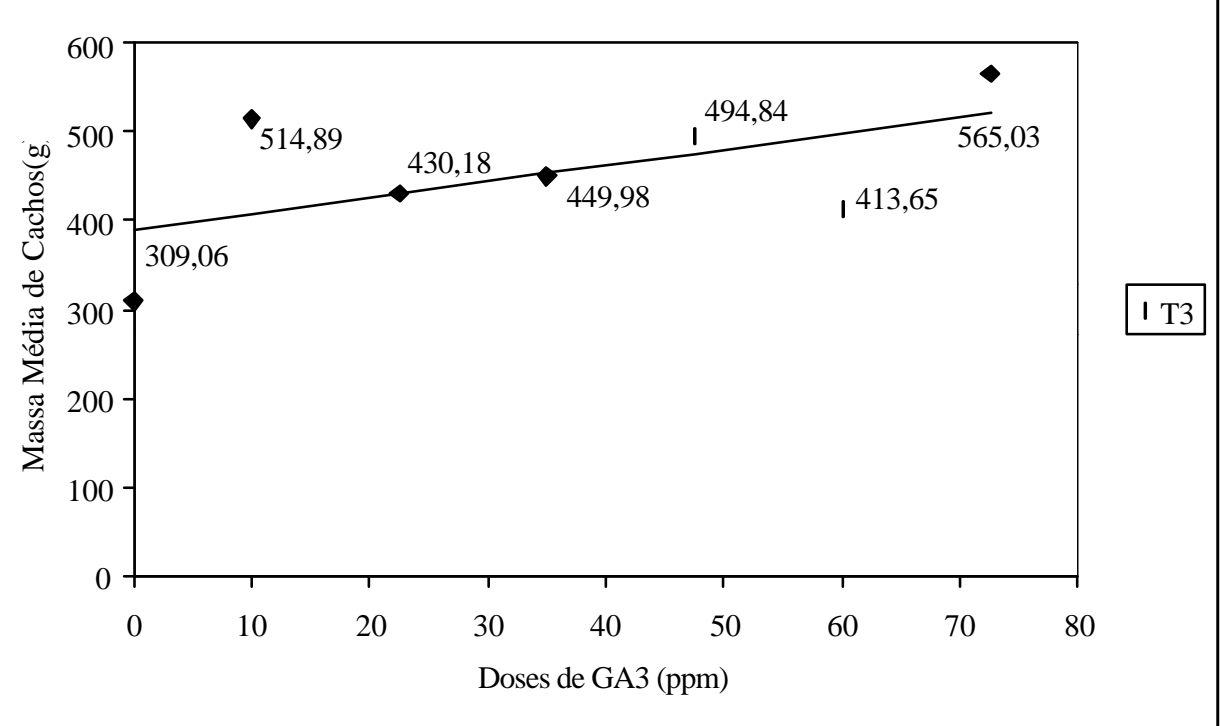

Figura 52 - Efeito da aplicação de diferentes doses de ácido giberélico, realizada juntamente com a prática do desponte de cachos, sobre a massa média dos cachos da cultivar Vênus, durante o ciclo vegetativo de 2000.

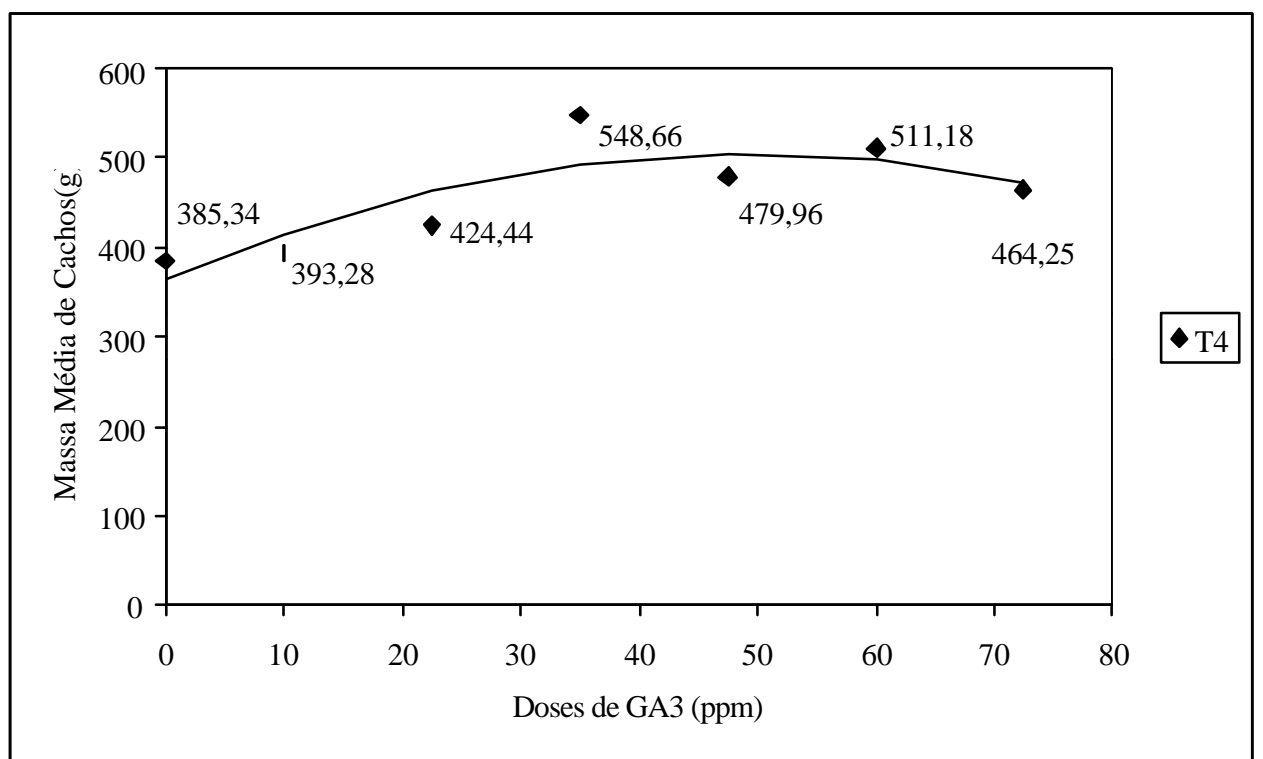

Figura 53 - Efeito da aplicação de diferentes doses de ácido giberélico, realizada juntamente com a prática do anelamento de ramos e do desponte de cachos, sobre a massa média dos cachos da cultivar Vênus, durante o ciclo vegetativo de 2000 . 
Tabela 43. Aplicação do teste de Tukey e de regressão polinomial para o número médio de bagos por cacho da cultivar Vênus durante o ciclo vegetativo de 2000.

\begin{tabular}{|c|c|c|c|c|}
\hline Causas da variação & \multicolumn{4}{|c|}{ Teste de Tukey para as médias das técnicas dentro das doses de GA3 } \\
\hline Doses de GA3 & Técnica 1 & Técnica 2 & Técnica 3 & Técnica 4 \\
\hline Oppm & $131,000 \mathrm{ab} A B$ & 157,567 a $\mathrm{A}$ & 101,216 b B & 145,766 a $\mathrm{AB}$ \\
\hline 10,0ppm & $133,867 \mathrm{~b} \mathrm{AB}$ & $130,300 \mathrm{~b} \mathrm{AB}$ & 174,099 a $\mathrm{A}$ & 122,000 b B \\
\hline 22,5ppm & $134,566 \mathrm{a} \mathrm{A}^{(1)}$ & 131,533 a A & 127,183 a $A$ & 138,067 a $A$ \\
\hline 35,0ppm & 124,750 с B & 179,483 a $\mathrm{A}$ & $137,000 \mathrm{bc} \mathrm{AB}$ & $164,716 \mathrm{ab} \mathrm{AB}$ \\
\hline 47,5ppm & 133,400 a $\mathrm{A}$ & 165,950 a A & 171,933 a $A$ & 147,550 a A \\
\hline 60,0ppm & $129,350 \mathrm{ab} A$ & 161,250 a $\mathrm{A}$ & 115,317 b A & $138,666 \mathrm{ab} A$ \\
\hline \multirow[t]{3}{*}{$72,5 \mathrm{ppm}$} & 153,250 a $A$ & 162,933 a $A$ & 165,066 a A & 146,100 a $\mathrm{A}$ \\
\hline & \multicolumn{4}{|c|}{$\begin{array}{l}\text { Regressão Polinomial para as doses de Ácido Giberélico dentro dos } \\
\text { níveis do fator técnicas }\end{array}$} \\
\hline & Técnica 1 & Técnica 2 & Técnica 3 & Técnica 4 \\
\hline Efeito Linear & $0,994 \mathrm{~ns}^{(2)}$ & $4,050 *(3)$ & $3,895^{*}$ & $0,625 \mathrm{~ns}$ \\
\hline Efeito Quadrático & $1,504 \mathrm{~ns}$ & $0,093 \mathrm{~ns}$ & $0,839 \mathrm{~ns}$ & $0,516 \mathrm{~ns}$ \\
\hline
\end{tabular}

${ }^{(1)}$ Médias dentro de uma linha seguidas de uma mesma letra minúscula ou maiúscula não diferem significativamente ao nível de $5 \%$ e $1 \%$ de probabilidade, respectivamente.

(2) Não significativo ao nível de $5 \%$ de probabilidade.

${ }^{(3)}$ Significativo ao nível de $5 \%$ de probabilidade.

Considerando o número de bagos por cacho, pode-se afirmar que, houve efeito da aplicação de ácido giberélico apenas quando esta foi realizada conjuntamente com o anelamento de ramos ou com o desponte de cachos. Notou-se que, juntamente com o anelamento de ramos, as doses de 35 e 47,5ppm originaram os maiores números médios de bagos por cacho (Figura 54), enquanto que com o desponte de cachos, maiores valores foram obtidos com as doses de 10 e 47,5ppm (Figura 55).

Com relação ao efeito de técnicas, este não foi significativo quando as doses 22,5; 47,5 e 72,5ppm foram aplicadas. Aplicando-se 35ppm conjuntamente com o anelamento de ramos, obteve-se maior número de bagos significativamente, comparando-se aos tratamentos em que o ácido giberélico foi aplicado sozinho ou em conjunto com o desponte de cachos. Já, não houve diferença estatística entre este tratamento e àquele em que esta mesma dose do regulador foi aplicada conjuntamente com o desponte de cachos e o anelamento de ramos (Tabela 43). Sendo assim, pode-se dizer que para a cultivar Vênus, a redução no número de bagos por cacho devido ao desponte é irrelevante, desde que conjuntamente realize-se o anelamento de ramos. Segundo Winkler et al. (1974) o anelamento influencia diretamente o desenvolvimento 
da inflorescência e frutificação, podendo ocorrer um aumento no número de bagos e no pegamento dos frutos durante ou imediatamente após o florescimento.

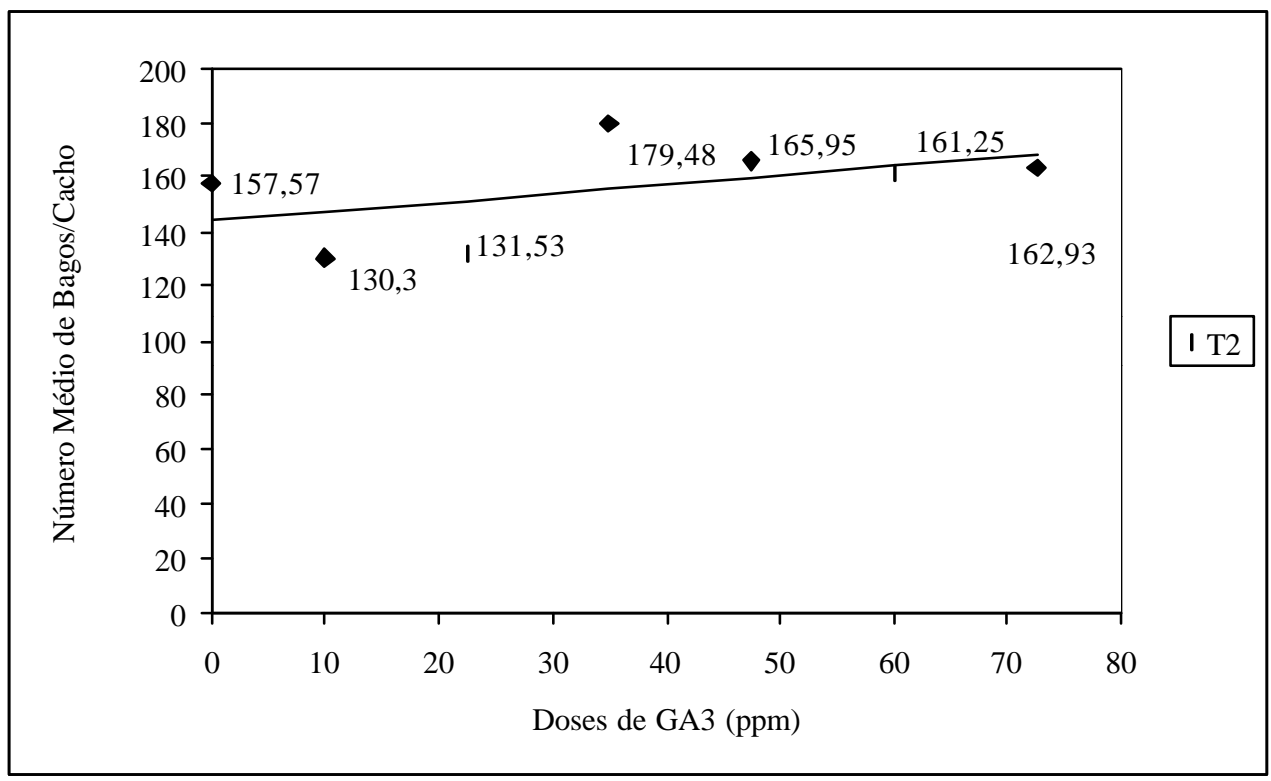

Figura 54 - Efeito da aplicação de diferentes doses de ácido giberélico, realizada juntamente com a prática do anelamento de ramos, sobre o número médio de bagos por cacho da cultivar Vênus, durante o ciclo vegetativo de 2000.

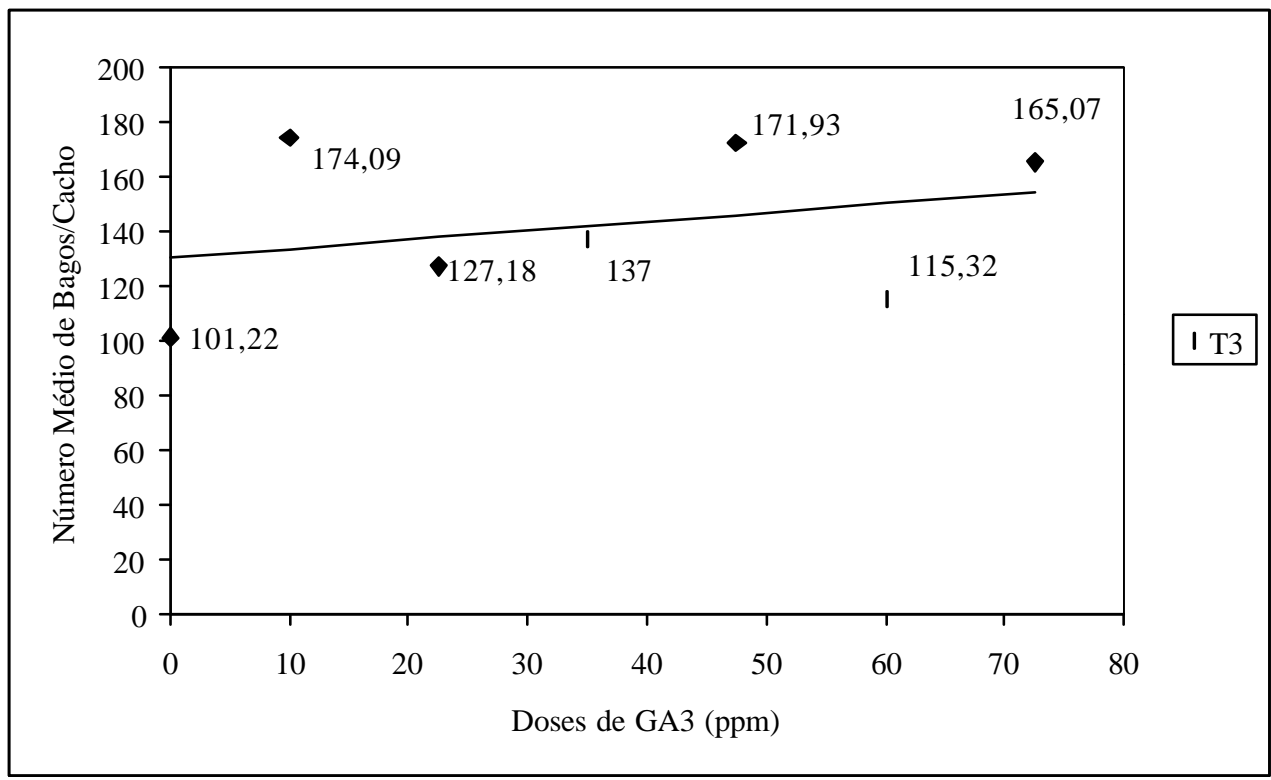

Figura 55 - Efeito da aplicação de diferentes doses de ácido giberélico, realizada juntamente com a pática do desponte de cachos, sobre o número médio de bagos por cacho da cultivar Vênus, durante o ciclo vegetativo de 2000 . 
Tabela 44. Aplicação do Teste "F" para as características mensuradas nos engaços da cultivar Vênus durante o ciclo vegetativo de 2000.

\begin{tabular}{lcccc}
\hline $\begin{array}{l}\text { Causas da } \\
\text { Variação }\end{array}$ & $\begin{array}{l}\text { Comprimento dos } \\
\text { engaços }(\mathrm{cm})\end{array}$ & $\begin{array}{l}\text { Largura dos } \\
\text { engaços }(\mathrm{cm}) \\
\text { Teste “F” }\end{array}$ & $\begin{array}{l}\text { Massa dos } \\
\text { engaços }(\mathrm{g})\end{array}$ & $\begin{array}{l}\text { Diâmetro dos } \\
\text { pedicelos }(\mathrm{mm})\end{array}$ \\
\hline Técnicas & $34,053^{* *(3)}$ & $0,521 \mathrm{~ns}^{(1)}$ & $8,732^{* *}$ & $7,117^{* *}$ \\
Doses de GA3 & $4,056^{* *}$ & $5,629^{* *}$ & $7,272^{* *}$ & $8,691^{* *}$ \\
Interação & $3,471^{* *}$ & $4,703^{* *}$ & $2,467^{* *}$ & $2,086^{*(2)}$ \\
Técnicas x GA3 & & & & \\
${ }^{(1)}$ Não significativo ao nível de 5\% de probabilidade. \\
${ }^{(2)}$ Significativo ao nível de 5\% de probabilidade. \\
${ }^{(3)}$ Significativo ao nível de 1\% de probabilidade.
\end{tabular}

Devido ao desponte de cachos, verifica-se na Tabela 45, um encurtamento nos engaços quando esta técnica foi realizada isoladamente ou conjuntamente com o anelamento de ramos.

Também, nota-se efeito significativo da aplicação de ácido giberélico isoladamente, em conjunto com o anelamento ou com o desponte de cachos, havendo uma tendência de aumento no comprimento médio dos engaços com o aumento das doses (Figuras 56, 57 e 58).

Tabela 45. Aplicação do teste de Tukey e de regressão polinomial para o comprimento médio do engaço da cultivar Vênus durante o ciclo vegetativo de 2000.

\begin{tabular}{|c|c|c|c|c|}
\hline Causas da variação & \multicolumn{4}{|c|}{ Teste de Tukey para as médias das técnicas dentro das doses de GA3 } \\
\hline Doses de GA3 & Técnica 1 & Técnica 2 & Técnica 3 & Técnica 4 \\
\hline 0ppm & $15,520 \mathrm{a} \mathrm{A}^{(1)}$ & 17,105 a A & $11,930 \mathrm{~b} \mathrm{~B}$ & 16,030 a $\mathrm{A}$ \\
\hline 10,0ppm & 16,335 a $\mathrm{A}$ & $15,330 \mathrm{ab} A$ & $15,182 \mathrm{ab} A$ & $13,870 \mathrm{~b} \mathrm{~A}$ \\
\hline 22,5ppm & 17,950 a A & $14,617 \mathrm{~b}$ B & $14,030 \mathrm{~b} \mathrm{~B}$ & $13,368 \mathrm{~b} \mathrm{~B}$ \\
\hline $35,0 \mathrm{ppm}$ & $16,060 \mathrm{ab} A B$ & 17,130 a $\mathrm{A}$ & $14,515 \mathrm{~b} \mathrm{~B}$ & $15,412 \mathrm{ab} A B$ \\
\hline 47,5ppm & 17,340 a $\mathrm{A}$ & 17,495 a $\mathrm{A}$ & $14,450 \mathrm{~b} \mathrm{~B}$ & $15,525 \mathrm{ab} A B$ \\
\hline 60,0ppm & 17,615 a A & $17,215 \mathrm{ab} \mathrm{A}$ & 15,483 bc $\mathrm{AB}$ & 14,427 c B \\
\hline \multirow[t]{3}{*}{ 72,5ppm } & 17,570 a $\mathrm{A}$ & 17,727 a A & $15,672 \mathrm{ab} A B$ & 14,507 b B \\
\hline & \multicolumn{4}{|c|}{$\begin{array}{c}\text { Regressão Polinomial para as doses de Ácido Giberélico dentro dos } \\
\text { níveis do fator técnicas }\end{array}$} \\
\hline & Técnica 1 & Técnica 2 & Técnica 3 & Técnica 4 \\
\hline Efeito Linear & $6,863 * *(3)$ & $8,301 * *$ & $15,465 * *$ & $0,121 \mathrm{~ns}$ \\
\hline Efeito Quadrático & $0,761 \mathrm{~ns}^{(2)}$ & $2,271 \mathrm{~ns}$ & $0,808 \mathrm{~ns}$ & $0,377 \mathrm{~ns}$ \\
\hline
\end{tabular}




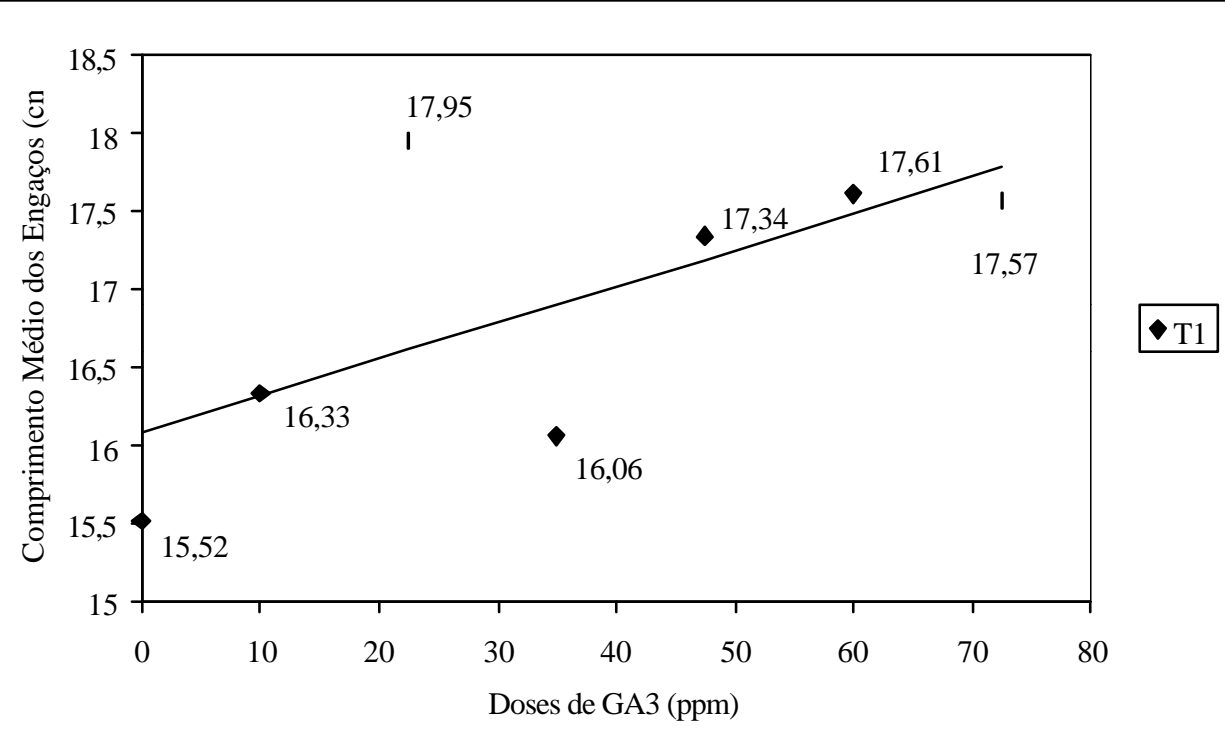

Figura 56 - Efeito da aplicação de diferentes doses de ácido giberélico, realizada isoladamente (sem a prática do anelamento de ramos e/ou desponte de cachos), sobre o comprimento médio dos engaços da cultivar Vênus, durante o ciclo vegetativo de 2000.

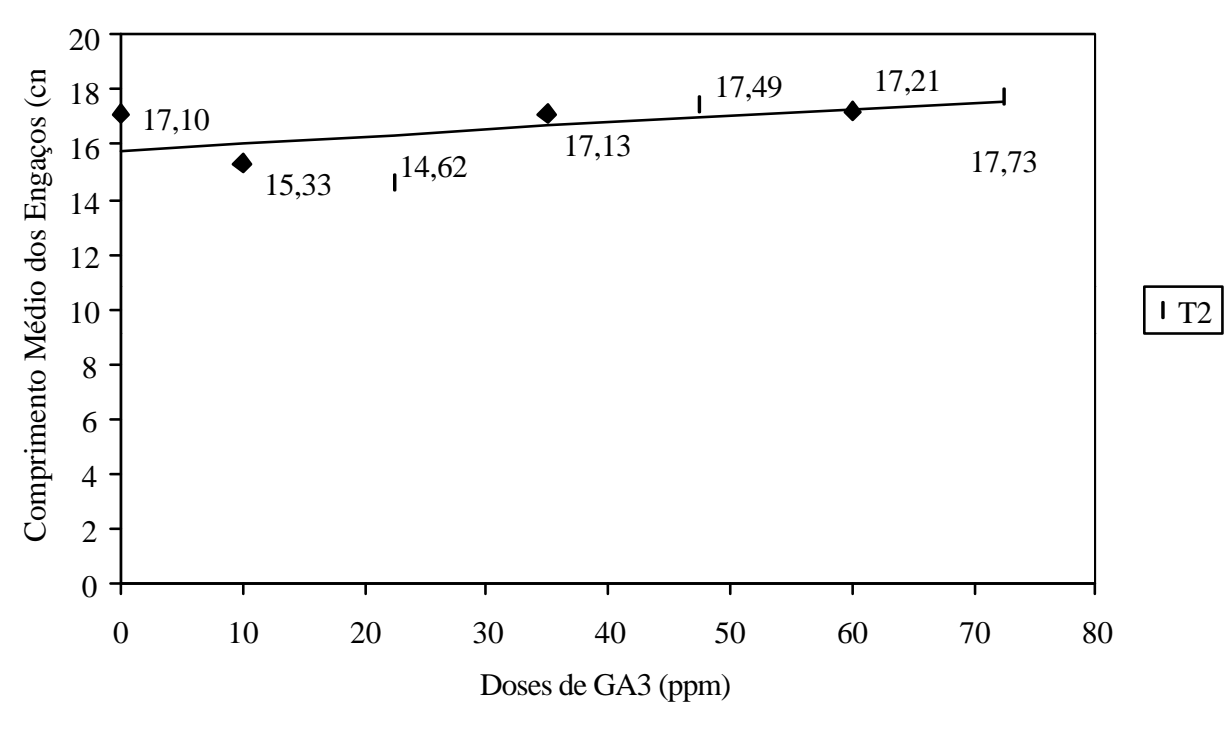

Figura 57 - Efeito da aplicação de diferentes doses de ácido giberélico, realizada juntamente com a prática do anelamento de ramos, sobre o comprimento médio dos engaços da cultivar Vênus, durante o ciclo vegetativo de 2000. 


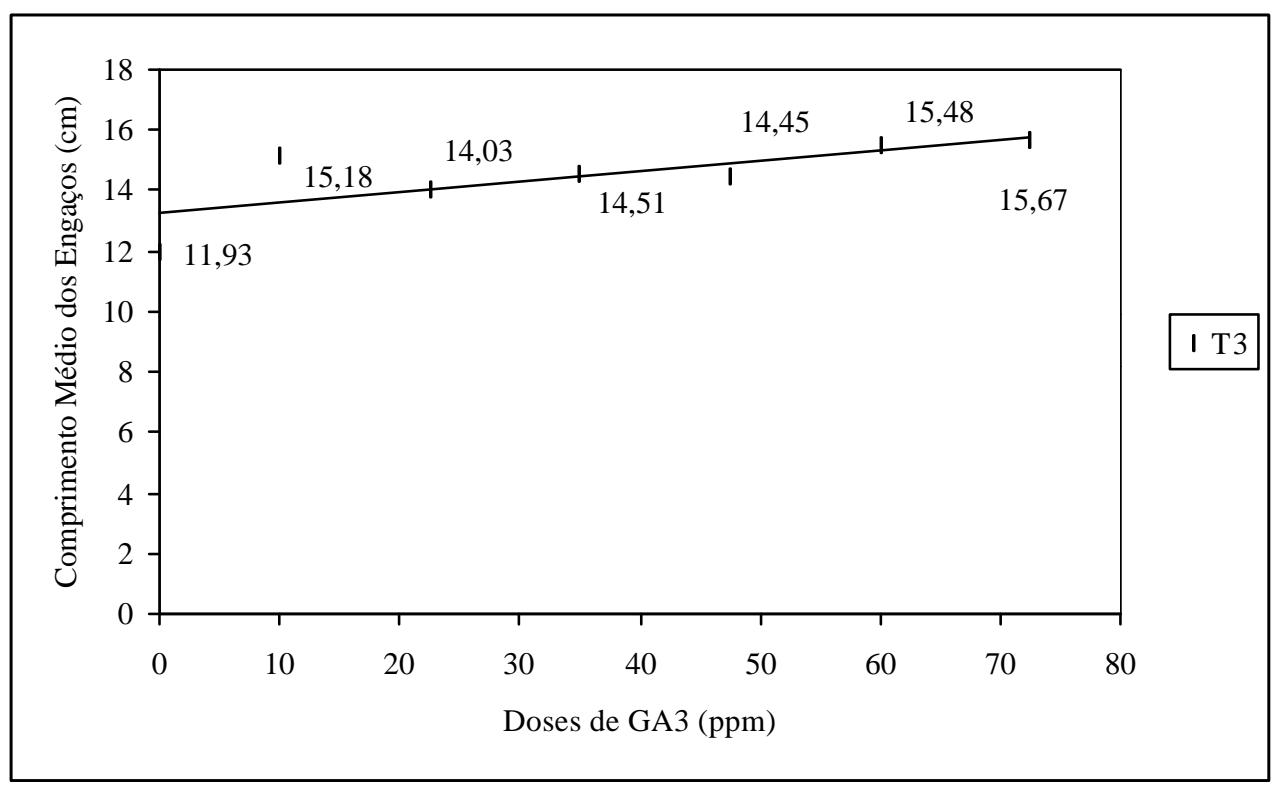

Figura 58 - Efeito da aplicação de diferentes doses de ácido giberélico, realizada juntamente com a prática do desponte de cachos, sobre o comprimento médio dos engaços da cultivar Vênus, durante o ciclo vegetativo de 2000 .

Tabela 46. Aplicação do teste de Tukey e de regressão polinomial para a largura média do engaço da cultivar Vênus durante o ciclo vegetativo de 2000.

\begin{tabular}{|c|c|c|c|c|}
\hline Causas da variação & \multicolumn{4}{|c|}{ Teste de Tukey para as médias das técnicas dentro das doses de GA3 } \\
\hline Doses de GA3 & Técnica 1 & Técnica 2 & Técnica 3 & Técnica 4 \\
\hline Oppm & $8,322 \mathrm{a} \mathrm{A}^{(1)}$ & 10,375 a $A$ & 8,293 a A & 8,885 a $A$ \\
\hline 10,0ppm & 10,512 a A & 8,875 ab A & $9,340 \mathrm{ab} A$ & $7,800 \mathrm{~b} \mathrm{~A}$ \\
\hline $22,5 \mathrm{ppm}$ & 9,820 a $\mathrm{A}$ & 7,792 a $\mathrm{A}$ & 8,272 a $A$ & 8,313 a $\mathrm{A}$ \\
\hline 35,0 ppm & 9,077 a $\mathrm{A}$ & 10,990 a $\mathrm{A}$ & 9,693 a $\mathrm{A}$ & 9,957 a $\mathrm{A}$ \\
\hline 47,5ppm & 8,685 b B & $10,495 \mathrm{ab} A B$ & 9,095 b B & 12,495 a A \\
\hline $60,0 \mathrm{ppm}$ & 9,770 a $\mathrm{A}$ & 10,000 a $\mathrm{A}$ & 9,243 a $A$ & 9,715 a $\mathrm{A}$ \\
\hline \multirow[t]{3}{*}{ 72,5ppm } & $11,365 \mathrm{ab} A B$ & $9,690 \mathrm{bc}$ BC & 12,940 a $\mathrm{A}$ & 8,325 с C \\
\hline & \multicolumn{4}{|c|}{$\begin{array}{c}\text { Regressão Polinomial para as doses de Ácido Giberélico dentro dos } \\
\text { níveis do fator técnicas }\end{array}$} \\
\hline & Técnica 1 & Técnica 2 & Técnica 3 & Técnica 4 \\
\hline Efeito Linear & $3,904 *(3)$ & $0,915 \mathrm{~ns}$ & $20,509 * *(4)$ & $3,893^{*}$ \\
\hline Efeito Quadrático & $1,887 \mathrm{~ns}^{(2)}$ & $0,003 \mathrm{~ns}$ & $7,717 * *$ & $10,214 * *$ \\
\hline
\end{tabular}

(1) Médias dentro de uma linha seguidas de uma mesma letra minúscula ou maiúscula não diferem significativamente ao nível de $5 \%$ e $1 \%$ de probabilidade, respectivamente.

(2) Não significativo ao nível de $5 \%$ de probabilidade.

${ }^{(3)}$ Significativo ao nível de $5 \%$ de probabilidade.

${ }^{(4)}$ Significativo ao nível de $1 \%$ de probabilidade. 
A largura média do engaço também sofreu influência de doses de ácido giberélico. Quando aplicado isoladamente ou juntamente com o desponte de cachos, maiores larguras foram observadas com a dose 72,5ppm. Já, quando conjuntamente com o ácido giberélico realizaram-se as duas técnicas, maior largura foi observada com a dose 47,5ppm. Dentro desta dose, comparando-se o efeito das técnicas, nota-se maiores larguras significativamente quando o anelamento é realizado isoladamente ou conjuntamente com o desponte de cachos.

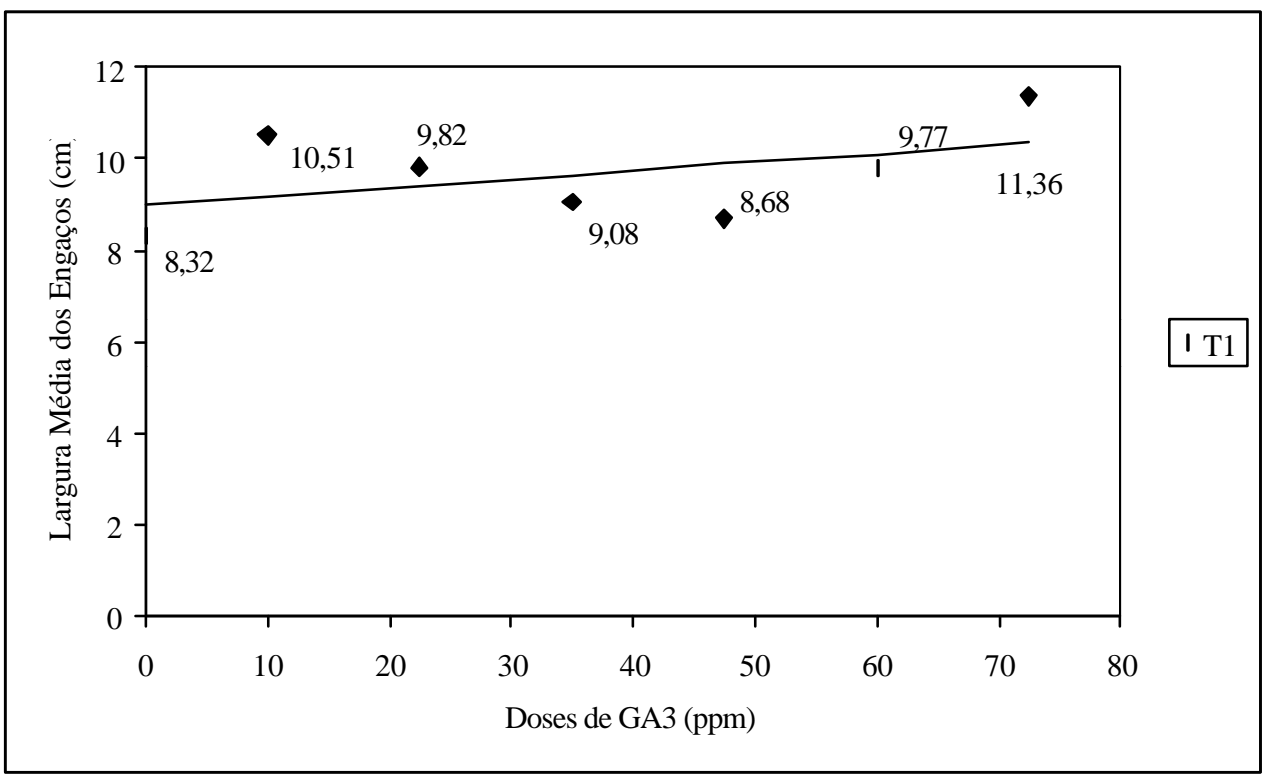

Figura 59 - Efeito da aplicação de diferentes doses de ácido giberélico, realizada isoladamente (sem a prática do anelamento de ramos e/ou desponte de cachos), sobre a largura média dos engaços da cultivar Vênus, durante o ciclo vegetativo de 2000 . 


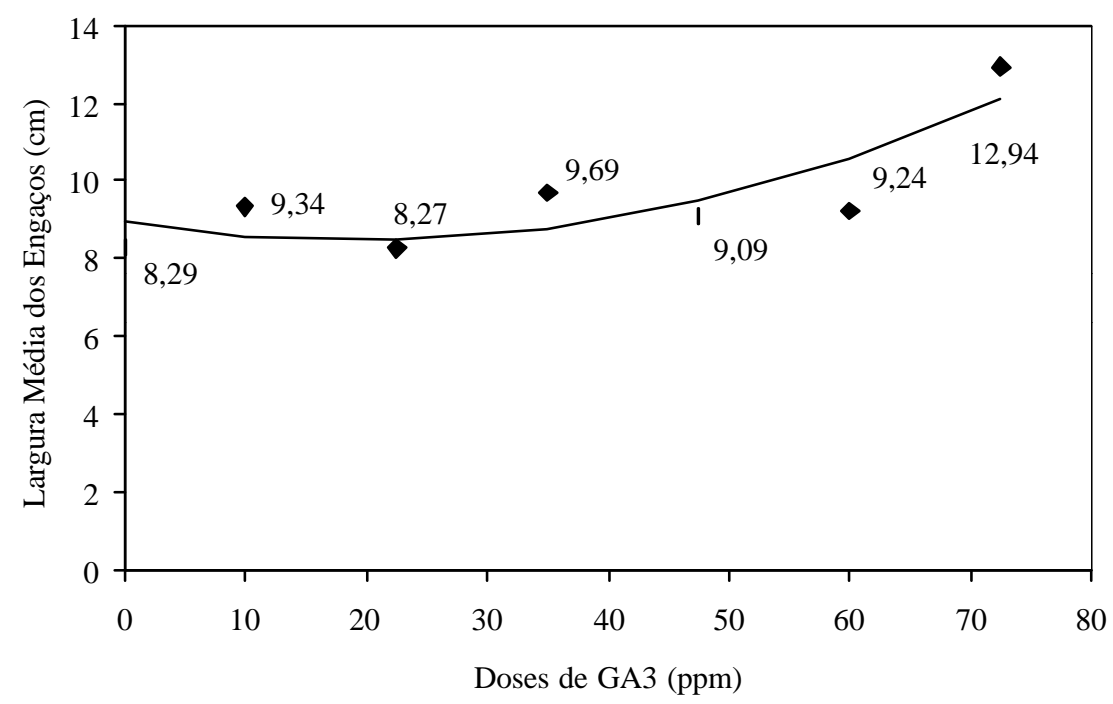

Figura 60 - Efeito da aplicação de diferentes doses de ácido giberélico, realizada juntamente com a prática do desponte de cachos, sobre a largura média dos engaços da cultivar Vênus, durante o ciclo vegetativo de 2000.

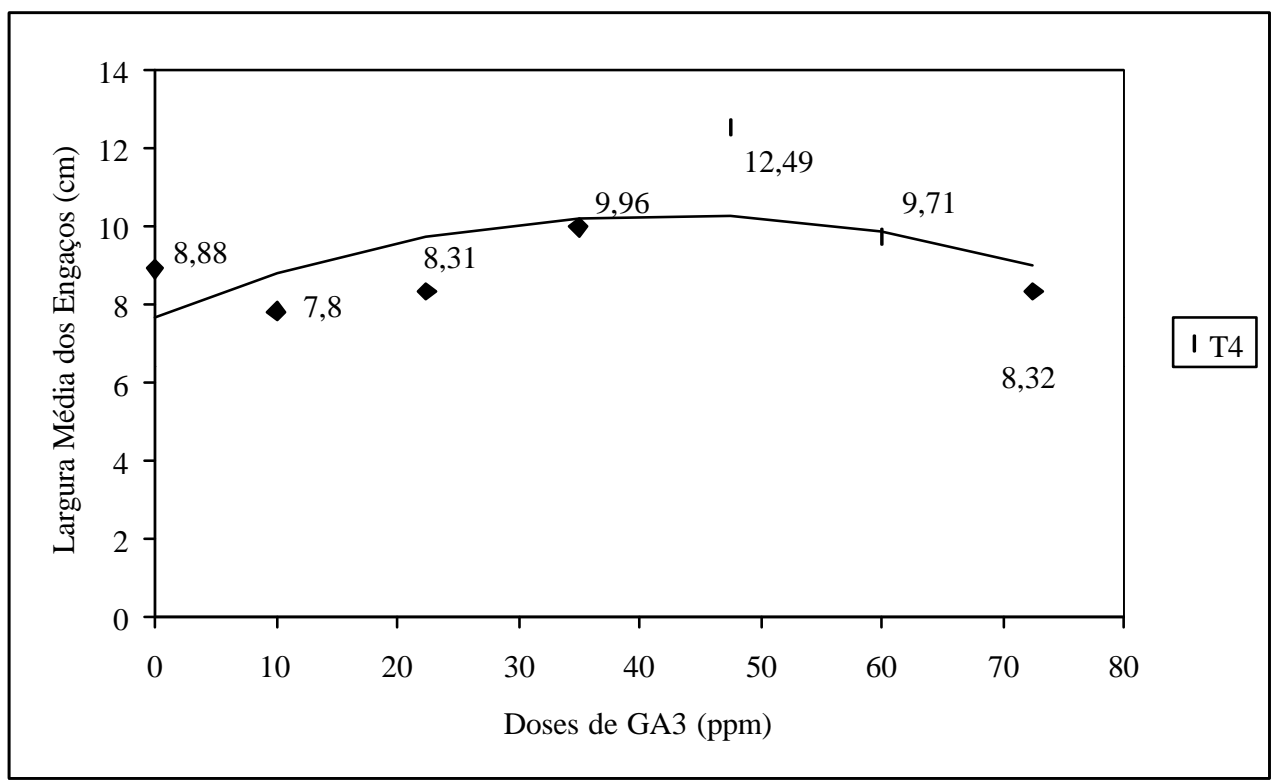

Figura 61 - Efeito da aplicação de diferentes doses de ácido giberélico, realizada juntamente com a prática do anelamento de ramos e do desponte de cachos, sobre a largura média dos engaços da cultivar Vênus, durante o ciclo vegetativo de 2000 . 
Tabela 47. Aplicação do teste de Tukey e de regressão polinomial para a massa média do engaço da cultivar Vênus durante o ciclo vegetativo de 2000.

\begin{tabular}{|c|c|c|c|c|}
\hline Causas da variação & \multicolumn{4}{|c|}{ Teste de Tukey para as médias das técnicas dentro das doses de GA3 } \\
\hline Doses de GA3 & Técnica 1 & Técnica 2 & Técnica 3 & Técnica 4 \\
\hline Oppm & $4,040 \mathrm{ab} A B$ & 5,450 a $\mathrm{A}$ & $2,977 \mathrm{~b} \mathrm{~B}$ & 4,885 a $\mathrm{AB}$ \\
\hline 10,0ppm & $4,208 \mathrm{ab} \mathrm{A}$ & $4,205 \mathrm{ab} \mathrm{A}$ & 5,612 a $\mathrm{A}$ & $3,925 \mathrm{~b} \mathrm{~A}$ \\
\hline 22,5ppm & 4,440 a $A^{(1)}$ & 4,892 a $\mathrm{A}$ & 3,750 a $\mathrm{A}$ & 5,105 a $\mathrm{A}$ \\
\hline 35,0ppm & $4,323 \mathrm{~b} \mathrm{~B}$ & 6,573 a $A$ & $4,678 \mathrm{~b} \mathrm{AB}$ & $5,780 \mathrm{ab} A B$ \\
\hline 47,5ppm & 4,960 a $\mathrm{A}$ & 6,375 a $\mathrm{A}$ & 5,052 a A & 5,445 a $\mathrm{A}$ \\
\hline 60,0ppm & 4,815 a $\mathrm{A}$ & 5,923 a $\mathrm{A}$ & 4,502 a $\mathrm{A}$ & 5,097 a $\mathrm{A}$ \\
\hline \multirow[t]{3}{*}{$72,5 \mathrm{ppm}$} & 5,850 a $\mathrm{A}$ & 6,422 a $\mathrm{A}$ & 6,237 a $A$ & 5,015 a $\mathrm{A}$ \\
\hline & \multicolumn{4}{|c|}{$\begin{array}{l}\text { Regressão Polinomial para as doses de Ácido Giberélico dentro dos } \\
\text { níveis do fator técnicas }\end{array}$} \\
\hline & Técnica 1 & Técnica 2 & Técnica 3 & Técnica 4 \\
\hline Efeito Linear & $10,013 * *(3)$ & $12,255^{* *}$ & $14,669 * *$ & $1,871 \mathrm{~ns}$ \\
\hline Efeito Quadrático & $0,941 \mathrm{~ns}^{(2)}$ & $0,214 \mathrm{~ns}$ & $0,184 \mathrm{~ns}$ & $2,318 \mathrm{~ns}$ \\
\hline
\end{tabular}

${ }^{(1)}$ Médias dentro de uma linha seguidas de uma mesma letra minúscula ou maiúscula não diferem significativamente ao nível de $5 \%$ e $1 \%$ de probabilidade, respectivamente.

${ }^{(2)}$ Não significativo ao nível de $5 \%$ de probabilidade.

${ }^{(3)}$ Significativo ao nível de $1 \%$ de probabilidade.

$\mathrm{Na}$ Tabela 47, nota-se que efeito significativo da aplicação de ácido giberélico isoladamente, em conjunto com o anelamento de ramos ou com o desponte de cachos. Sendo aplicado isoladamente ou conjuntamente com o desponte, maiores massas foram obtidas com a dose 72,5ppm (Figuras 62 e 64). Já, quando conjuntamente realizou-se o anelamento de ramos, a dose $35 \mathrm{ppm}$ originou o maior incremento na massa dos engaços (Figura 63). 


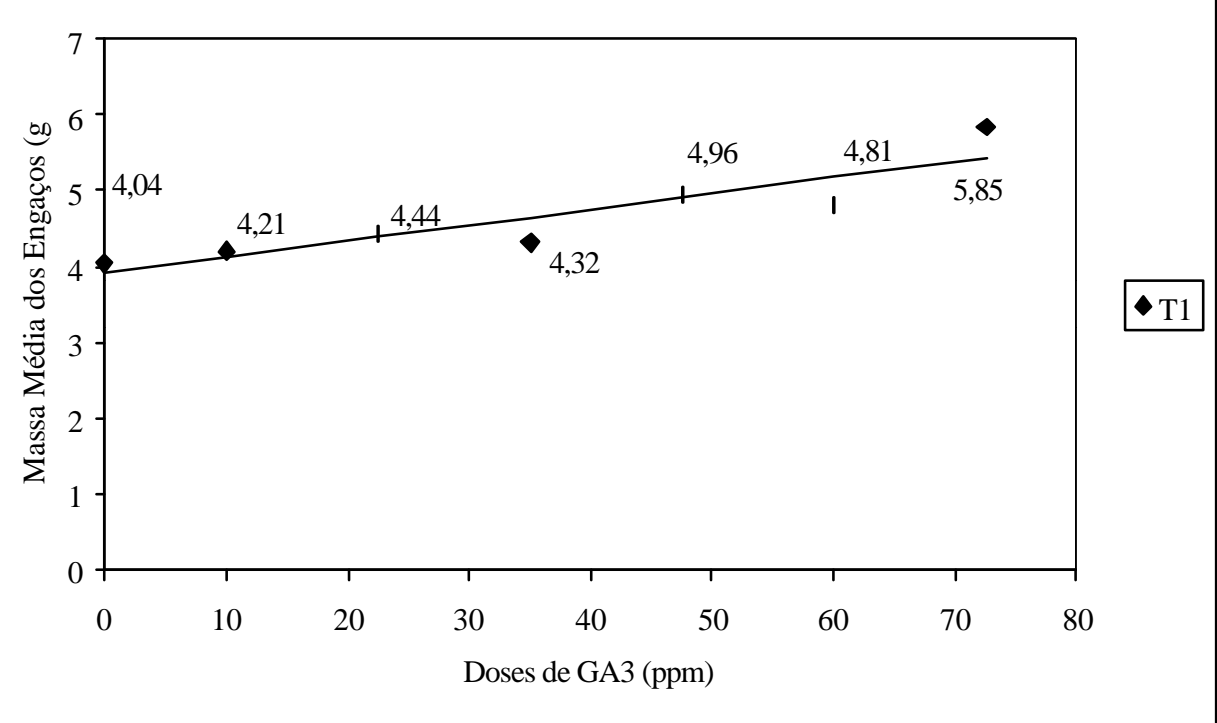

Figura 62 - Efeito da aplicação de diferentes doses de ácido giberélico, realizada isoladamente (sem a prática do anelamento de ramos e/ou desponte de cachos), sobre a massa média dos engaços da cultivar Vênus, durante o ciclo vegetativo de 2000 .

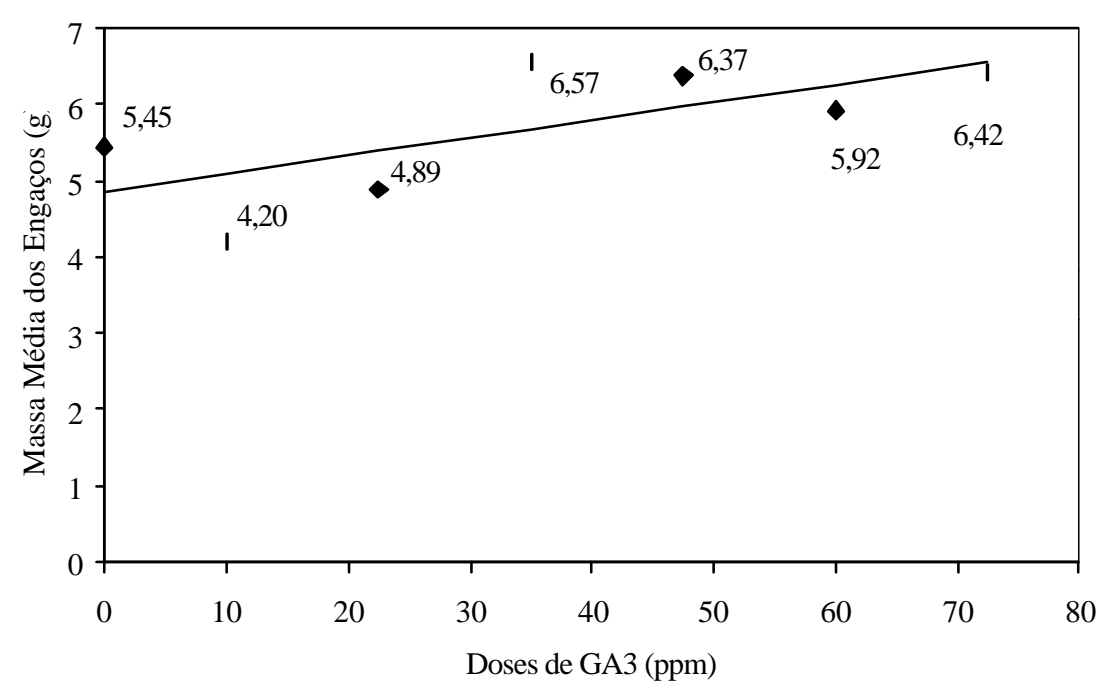

Figura 63 - Efeito da aplicação de diferentes doses de ácido giberélico, realizada juntamente com a prática do anelamento de ramos, sobre a massa média dos engaços da cultivar Vênus, durante o ciclo vegetativo de 2000. 


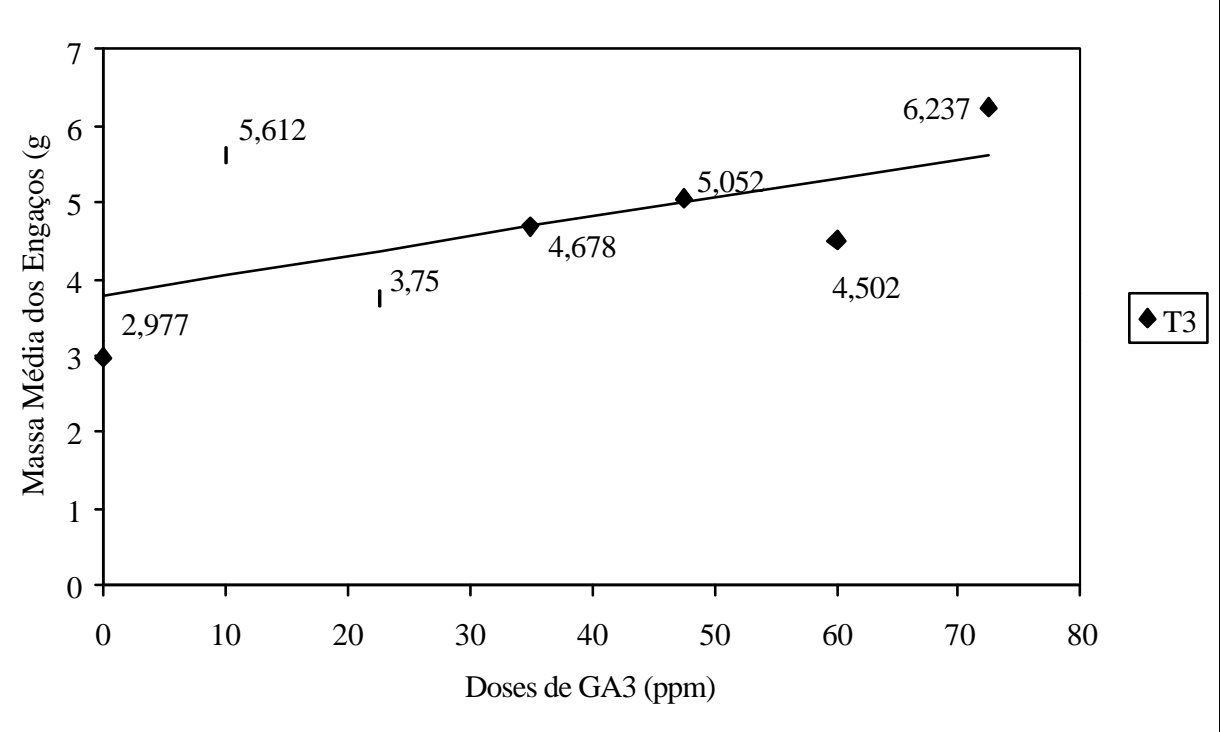

Figura 64 - Efeito da aplicação de diferentes doses de ácido giberélico, realizada conjuntamente com a prática do desponte de cachos, sobre a massa média dos engaços da cultivar Vênus, durante o ciclo vegetativo de 2000.

Tabela 48. Aplicação do teste de Tukey e de regressão polinomial para o diâmetro médio dos pedicelos da cultivar Vênus durante o ciclo vegetativo de 2000.

\begin{tabular}{lllll}
\hline Causas da variação & \multicolumn{4}{c}{ Teste de Tukey para as médias das técnicas dentro das doses de GA3 } \\
\hline Doses de GA3 & Técnica 1 & Técnica 2 & Técnica 3 & Técnica 4 \\
Oppm & 2,420 a A & 2,396 a A & 2,485 a A & 2,685 a A \\
10,0ppm & 2,425 b B & 2,845 a A & 2,457 b B & 2,550 b AB \\
$\mathbf{2 2 , 5 p p m}$ & 2,686 a A & 2,711 a A & 2,829 a A & 2,822 a A \\
35,0ppm & 2,576 a A & 2,631 a A & 2,494 a A & 2,761 a A \\
47,5ppm & 2,684 a A & 2,761 a A & 2,741 a A & 2,709 a A \\
60,0ppm & 2,684 b B & 2,728 b B & 2,742 b B & 3,140 a A \\
$\mathbf{7 2 , 5 p p m}$ & 2,702 a A & 2,771 a A & 2,648 a A & 2,766 a A
\end{tabular}

Regressão Polinomial para as doses de Ácido Giberélico dentro dos

$\begin{array}{lcllc} & \text { Técnica 1 } & \text { Técnica 2 } & \text { Técnica 3 } & \text { Técnica 4 } \\ \text { Efeito Linear } & 10,592^{* *(4)} & 4,656^{*(3)} & 5,364^{*} & 10,046^{* *} \\ \text { Efeito Quadrático } & 1,463 \mathrm{~ns}^{(2)} & 1,801 \mathrm{~ns} & 2,243 \mathrm{~ns} & 0,515 \mathrm{~ns}\end{array}$

(1) Médias dentro de uma linha seguidas de uma mesma letra minúscula ou maiúscula não diferem significativamente ao nível de 5\% e $1 \%$ de probabilidade, respectivamente.

${ }^{(2)}$ Não significativo ao nível de $5 \%$ de probabilidade.

${ }^{(3)}$ Significativo ao nível de $5 \%$ de probabilidade.

${ }^{(4)}$ Significativo ao nível de $1 \%$ de probabilidade.

Na Tabela 48 evidencia-se diferença estatística entre as técnicas apenas quando as doses 10 ou 60ppm foram aplicadas, notando-se maiores diâmetros de pedicelos 
quando o anelamento foi realizado isoladamente, ou em conjunto com o desponte de cachos, respectivamente.

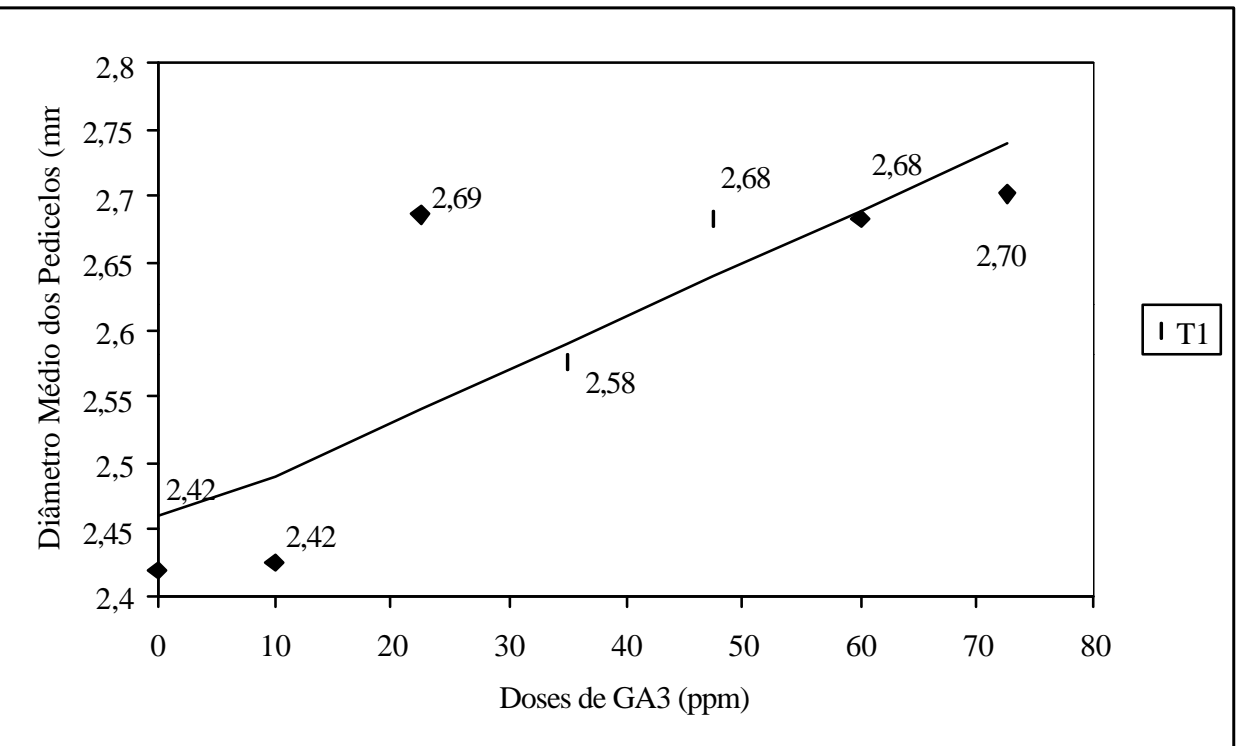

Figura 65 - Efeito da aplicação de diferentes doses de ácido giberélico, realizada isoladamente (sem a prática do anelamento de ramos e/ou desponte de cachos), sobre o diâmetro médio dos pedicelos da cultivar Vênus, durante o ciclo vegetativo de 2000.

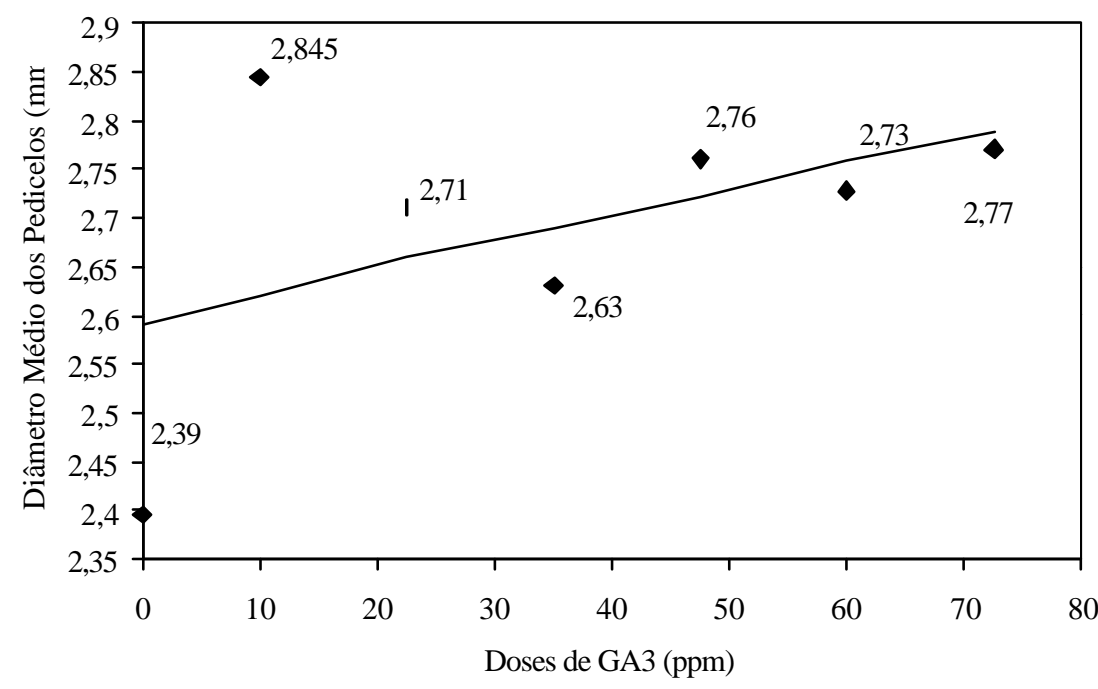

Figura 66 - Efeito da aplicação de diferentes doses de ácido giberélico, realizada juntamente com a prática do anelamento de ramos, sobre o diâmetro médio dos pedicelos da cultivar Vênus, durante o ciclo vegetativo de 2000 . 


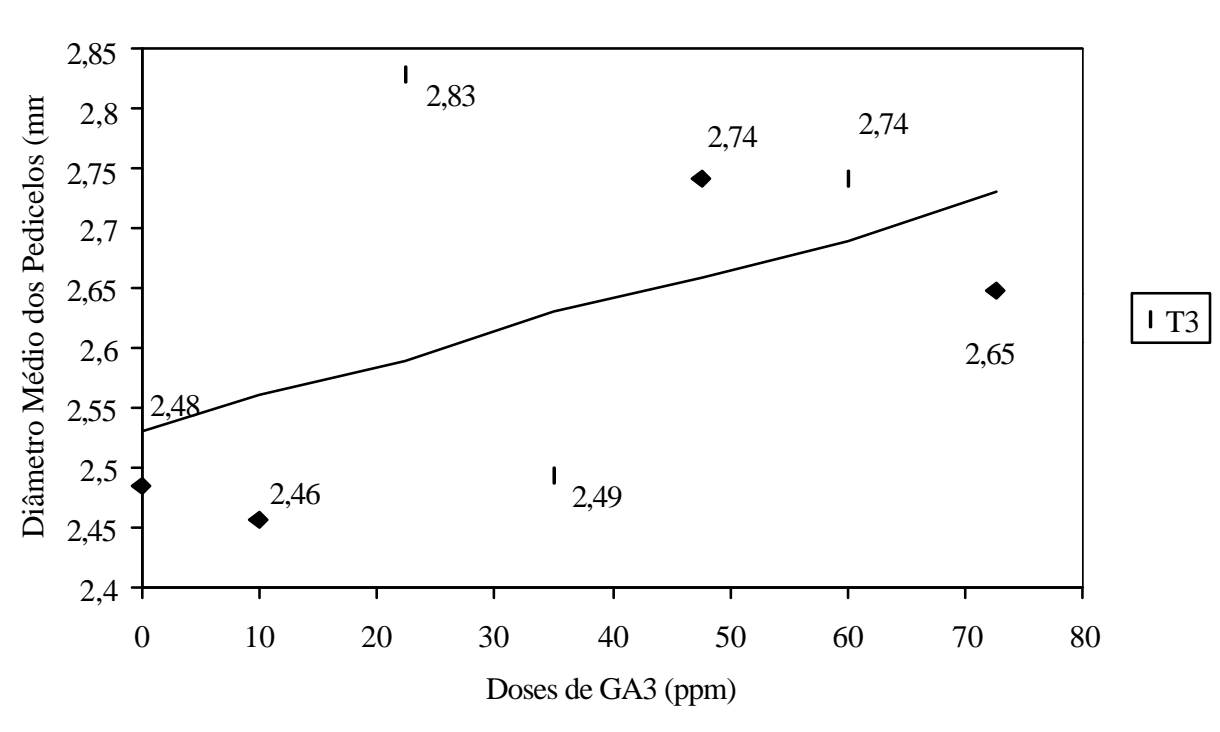

Figura 67 - Efeito da aplicação de diferentes doses de ácido giberélico, realizada juntamente com a prática do desponte de cachos, sobre o diâmetro médio dos pedic elos da cultivar Vênus, durante o ciclo vegetativo de 2000.

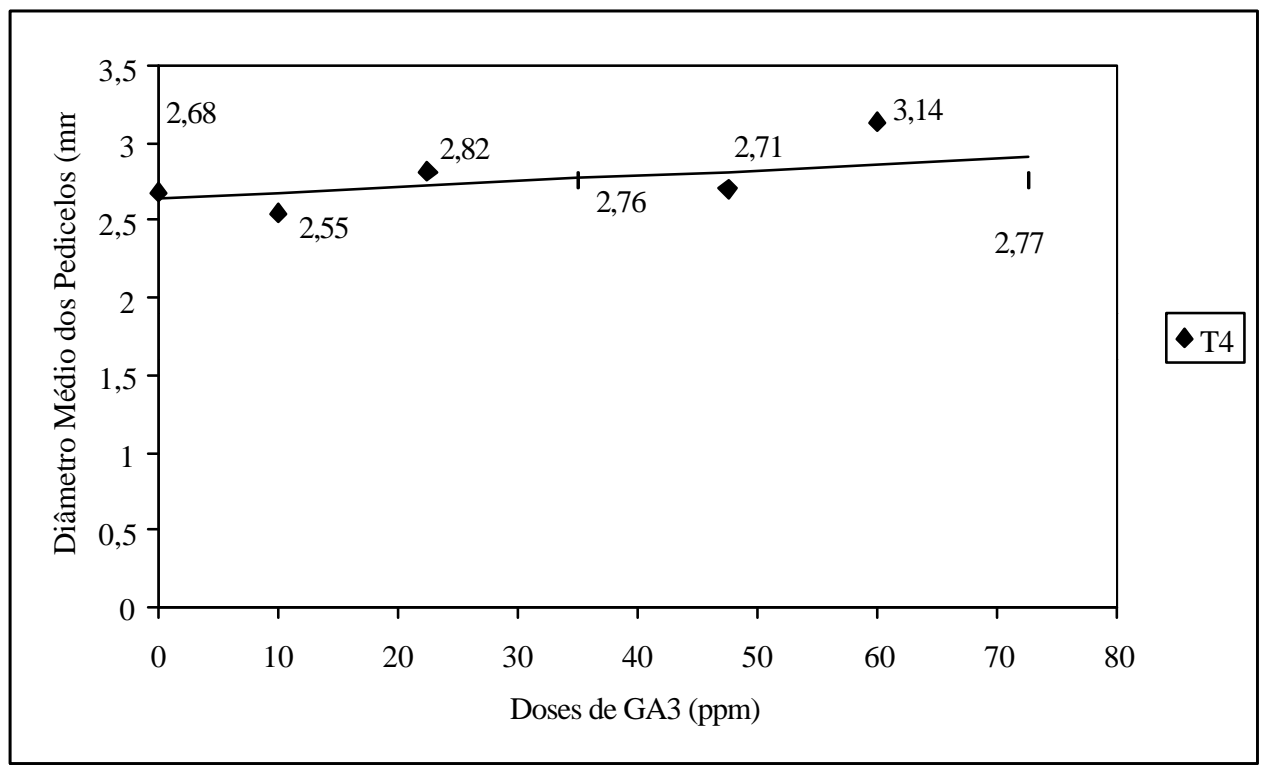

Figura 68 - Efeito da aplicação de diferentes doses de ácido giberélico, realizada conjuntamente com a prática do anelamento de ramos e do desponte de cachos, sobre o diâmetro médio dos pedicelos da cultivar Vênus, durante o ciclo vegetativo de 2000 . 
Tabela 49. Aplicação do Teste "F" para as características mensuradas nos bagos da cultivar Vênus durante o ciclo vegetativo de 2000.

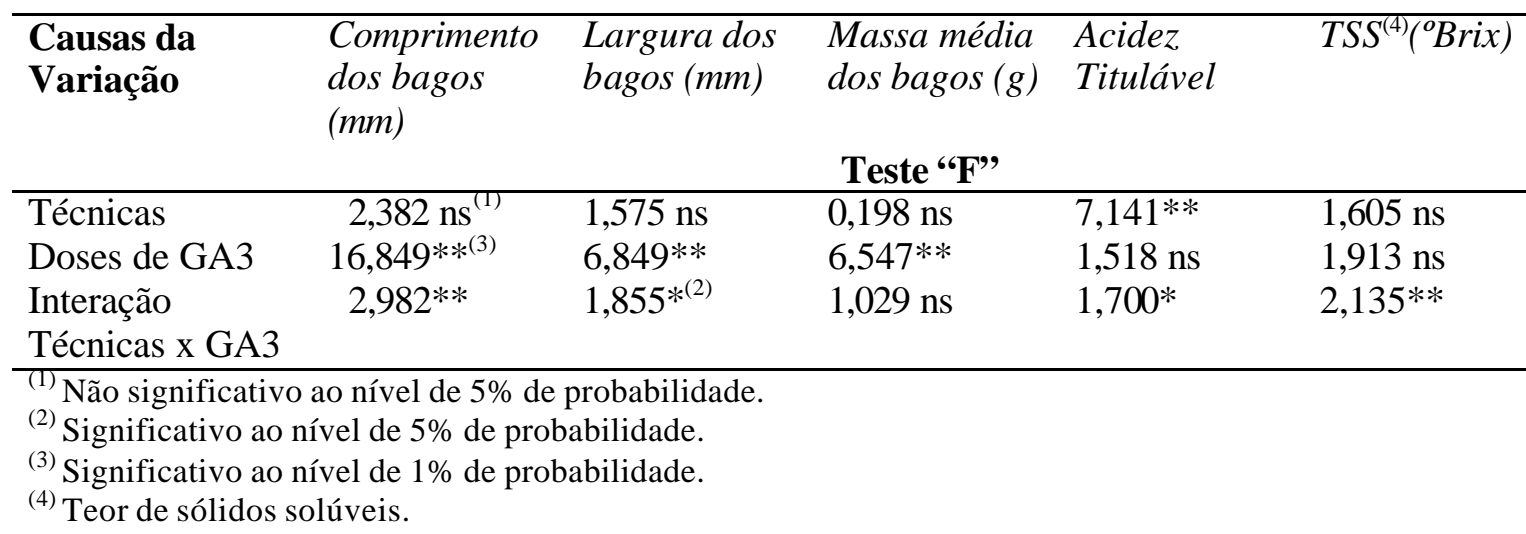

Tabela 50. Aplicação do teste de Tukey e de regressão polinomial para o comprimento médio dos bagos da cultivar Vênus durante o ciclo vegetativo de 2000.

\begin{tabular}{|c|c|c|c|c|}
\hline Causas da variação & \multicolumn{4}{|c|}{ Teste de Tukey para as médias das técnicas dentro das doses de GA3 } \\
\hline Doses de GA3 & Técnica 1 & Técnica 2 & Técnica 3 & Técnica 4 \\
\hline Oppm & $18,649 \mathrm{a} \mathrm{A}^{(1)}$ & 18,020 a A & 18,892 a A & 18,509 a A \\
\hline $10,0 \mathrm{ppm}$ & 19,615 a $\mathrm{A}$ & 20,480 a $\mathrm{A}$ & 19,882 a $\mathrm{A}$ & 20,600 a $\mathrm{A}$ \\
\hline 22,5ppm & 20,064 a $A$ & 19,479 a $A$ & 19,166 a $\mathrm{A}$ & 20,124 a A \\
\hline 35,0 ppm & 20,320 a $\mathrm{A}$ & 20,256 a A & 19,864 a $\mathrm{A}$ & 19,990 a $\mathrm{A}$ \\
\hline 47,5ppm & 20,526 a A & 20,255 a $\mathrm{A}$ & 20,046 a $\mathrm{A}$ & 19,856 a $\mathrm{A}$ \\
\hline $60,0 \mathrm{ppm}$ & $20,534 \mathrm{~b} \mathrm{~B}$ & 20,992 b B & 20,401 b B & 23,440 a $\mathrm{A}$ \\
\hline \multirow[t]{3}{*}{ 72,5ppm } & $20,312 \mathrm{ab} A B$ & $19,158 \mathrm{~b} \mathrm{~B}$ & 21,009 a A & $19,887 \mathrm{ab} \mathrm{AB}$ \\
\hline & \multicolumn{4}{|c|}{$\begin{array}{l}\text { Regressão Polinomial para as doses de Ácido Giberélico dentro dos } \\
\text { níveis do fator técnicas }\end{array}$} \\
\hline & Técnica 1 & Técnica 2 & Técnica 3 & Técnica 4 \\
\hline Efeito Linear & $11,169 * *(4)$ & $5,352 *(3)$ & $14,673 * *$ & $19,127 * *$ \\
\hline Efeito Quadrático & $5,079 *$ & $14,220 * *$ & $0,473 \mathrm{~ns}^{(2)}$ & $4,396 *$ \\
\hline $\begin{array}{l}\text { (1) Médias dentro de } \\
\text { significativamente } \\
\text { (2) Não significativo ao } \\
\text { (3) Significativo ao níve } \\
\text { (4) }\end{array}$ & $\begin{array}{l}\text { na linha seguidas } \\
\text { nível de } 5 \% \text { e } 1 \% \\
\text { ível de } 5 \% \text { de prob } \\
\text { de } 5 \% \text { de probabil }\end{array}$ & $\begin{array}{l}\text { e uma mesm } \\
\text { e probabilidad } \\
\text { ilidade. } \\
\text { ade. }\end{array}$ & a minúscula & iúscula não diferem \\
\hline
\end{tabular}

Primeiramente, com relação ao efeito de técnicas sobre o comprimento médio dos bagos, verifica-se que este foi significativo apenas quando as doses 60 e 72,5ppm foram aplicadas (Tabela 50). Aplicando-se 60ppm de ácido giberélico conjuntamente com as duas técnicas obteve-se maior comprimento médio de bagos. 
Já, com relação às doses do regulador vegetal, nota-se efeito significativo quando o ácido giberélico foi aplicado isoladamente, ou em conjunto com o anelamento e/ou o desponte de cachos (Tabela 50). Quando aplicado isoladamente ou em conjunto com o desponte apenas, maiores comprimentos foram obtidos com doses maiores (Figuras 69 e 71). Já, quando conjuntamente realizou-se o anelamento isoladamente ou em conjunto com o desponte de cachos, os maiores comprimentos foram obtidos com a dose 60ppm (Figuras 70 e 72).

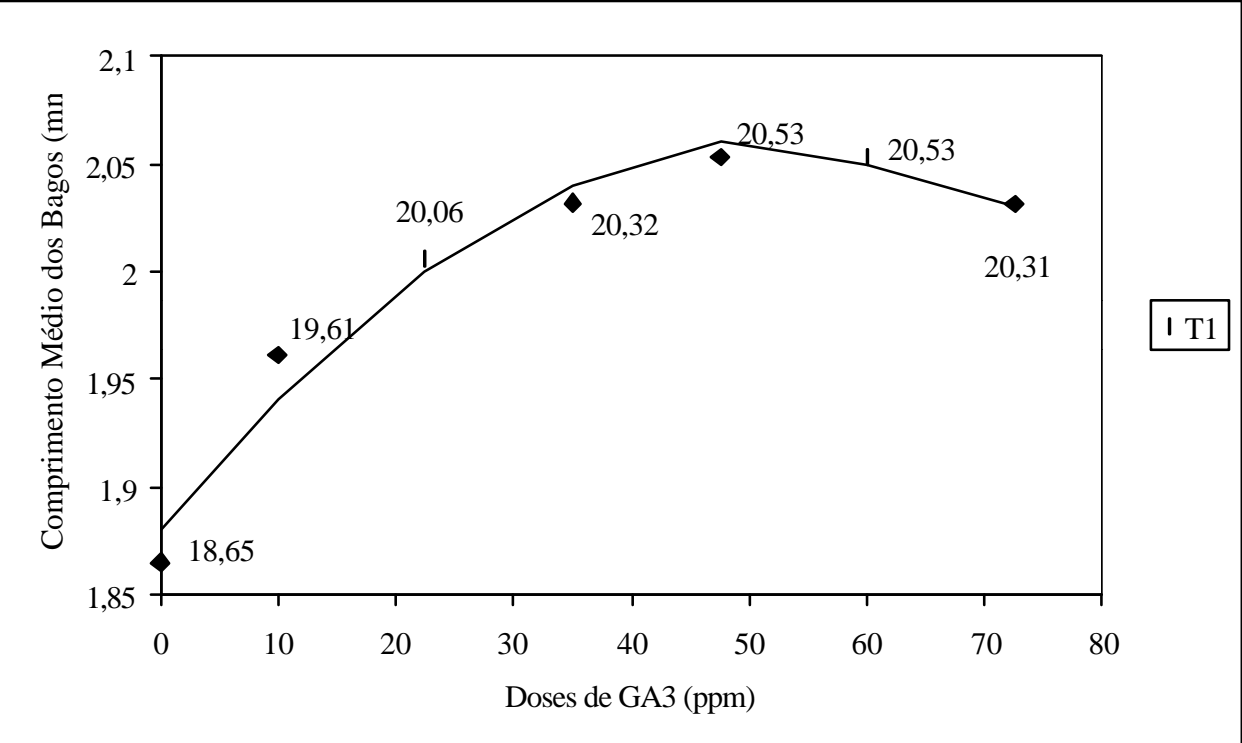

Figura 69 - Efeito da aplic ação de diferentes doses de ácido giberélico, realizada isoladamente (sem a prática do anelamento de ramos e/ou desponte de cachos), sobre o comprimento médio dos bagos da cultivar Vênus, durante o ciclo vegetativo de 2000. 


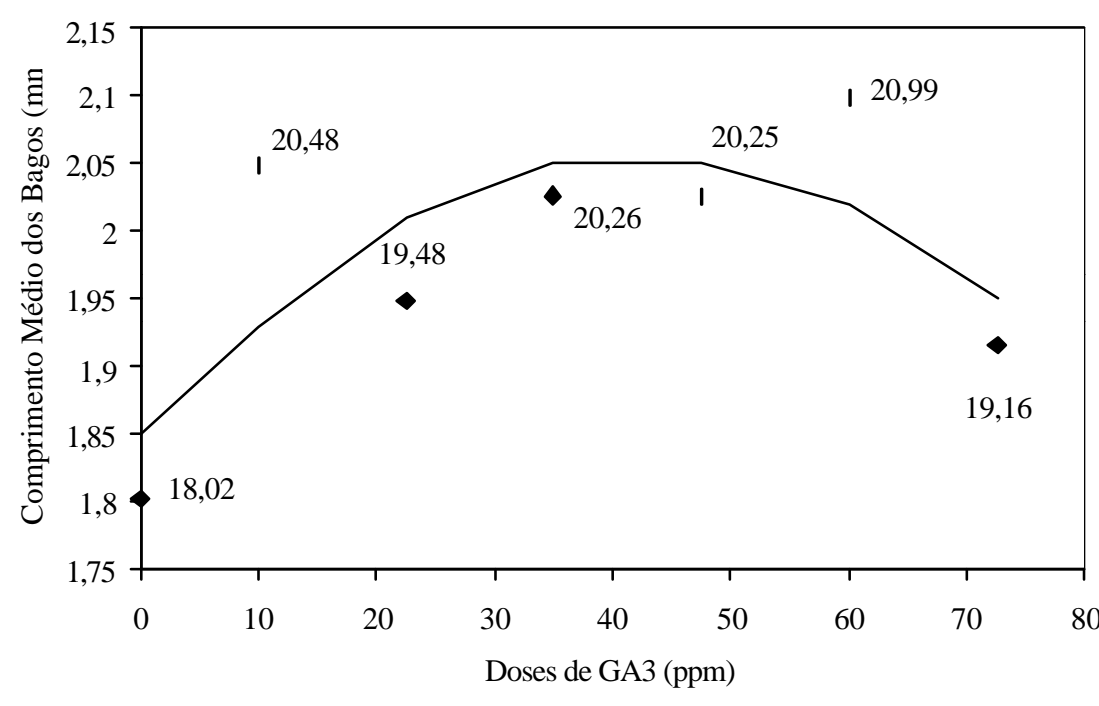

T 2

Figura 70 - Efeito da aplicação de diferentes doses de ácido giberélico, realizada juntamente com a prática do anelamento de ramos, sobre o comprimento médio dos bagos da cultivar Vênus, durante o ciclo vegetativo de 2000.

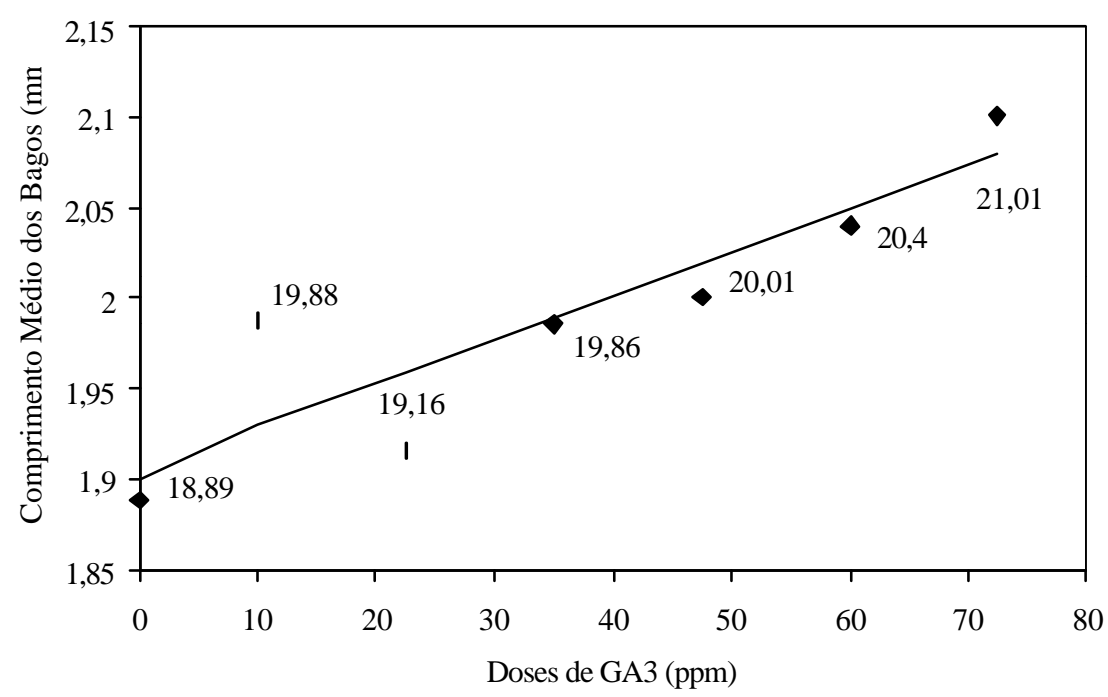

Figura 71 - Efeito da aplicação de diferentes doses de ácido giberélico, realizada juntamente com a prática do desponte de cachos, sobre o comprimento médio dos bagos da cultivar Vênus, durante o ciclo vegetativo de 2000. 


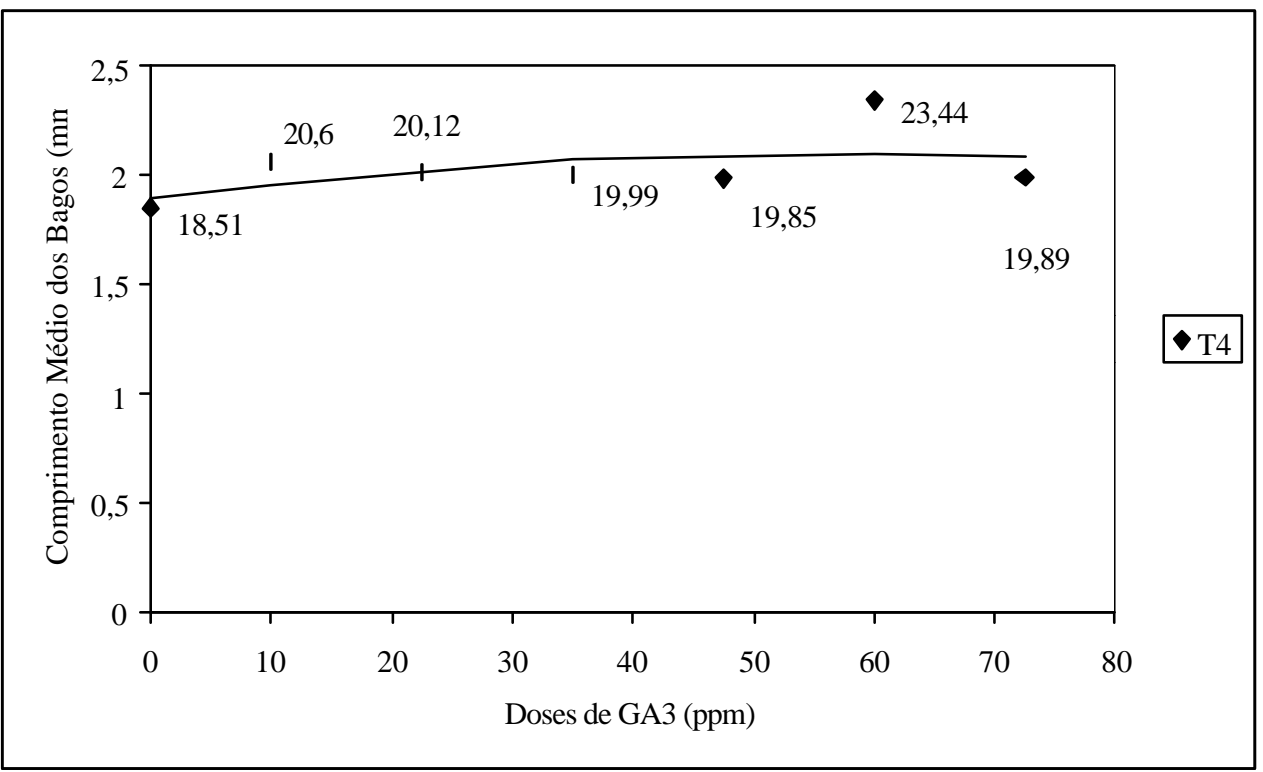

Figura 72 - Efeito da aplicação de diferentes doses de ácido giberélico, realizada juntamente com a prática do anelamento de ramos e do desponte de cachos, sobre o comprimento médio dos bagos da cultivar Vênus, durante o ciclo vegetativo de 2000 .

Tabela 51. Aplicação do teste de Tukey e de regressão polinomial para a largura média dos bagos da cultivar Vênus durante o ciclo vegetativo de 2000.

\begin{tabular}{|c|c|c|c|c|}
\hline Causas da variação & \multicolumn{4}{|c|}{ Teste de Tukey para as médias das técnicas dentro das doses de GA3 } \\
\hline Doses de GA3 & Técnica 1 & Técnica 2 & Técnica 3 & Técnica 4 \\
\hline 0ppm & $17,024 \mathrm{a} \mathrm{A}^{(1)}$ & 16,644 a A & 17,286 a A & 16,691 a $\mathrm{A}$ \\
\hline 10,0ppm & $17,447 \mathrm{ab} A$ & 18,000 a $\mathrm{A}$ & $17,421 \mathrm{ab} A$ & $16,506 \mathrm{~b} \mathrm{~A}$ \\
\hline 22,5ppm & $17,672 \mathrm{ab} A$ & 17,232 b A & 18,757 a $\mathrm{A}$ & $17,548 \mathrm{ab} A$ \\
\hline 35,0ppm & 18,240 a A & 17,806 a $\mathrm{A}$ & 17,547 a A & 17,507 a $\mathrm{A}$ \\
\hline 47,5ppm & 18,274 a A & 17,852 a $\mathrm{A}$ & 17,323 a A & 17,359 a $\mathrm{A}$ \\
\hline 60,0ppm & 18,052 a $\mathrm{A}$ & 18,890 a $\mathrm{A}$ & 18,354 a A & 19,220 a $\mathrm{A}$ \\
\hline \multirow[t]{3}{*}{ 72,5ppm } & $18,026 \mathrm{ab} A$ & 16,678 b A & 18,289 a $\mathrm{A}$ & $17,378 \mathrm{ab} A$ \\
\hline & \multicolumn{4}{|c|}{$\begin{array}{l}\text { Regressão Polinomial para as doses de Ácido Giberélico dentro dos } \\
\text { níveis do fator técnicas }\end{array}$} \\
\hline & Técnica 1 & Técnica 2 & Técnica 3 & Técnica 4 \\
\hline Efeito Linear & $5,076^{*(3)}$ & $1,251 \mathrm{~ns}$ & $2,594 \mathrm{~ns}$ & $11,950 * *$ \\
\hline Efeito Quadrático & $2,483 \mathrm{~ns}^{(2)}$ & $7,195 * *(4)$ & $0,015 \mathrm{~ns}$ & $1,867 \mathrm{~ns}$ \\
\hline $\begin{array}{l}\text { (1) Médias dentro de } \\
\text { significativamente } \\
\text { (2) Não significativo ao } \\
\text { (3) Significativo ao nív } \\
\text { (4) Significativo ao nív }\end{array}$ & ha se & $\begin{array}{l}\text { uma mes } \\
\text { robabilid } \\
\text { idade. }\end{array}$ & $\begin{array}{l}\text { minúscula } \\
\text { tivamente. }\end{array}$ & cula não d \\
\hline
\end{tabular}


Nota-se, na Tabela 51, efeito significativo de doses de ácido giberélico sobre a largura média dos bagos, quando este foi aplicado isoladamente, em conjunto com o anelamento de ramos ou conjuntamente com o anelamento e o desponte de cachos.

Aplicando-se apenas o ácido giberélico, maiores larguras médias de bagos foram observadas com as doses 35 e 47,5ppm, havendo ainda uma tendência de aumento nesta característica com o aumento das doses (Figura 73). Já, quando conjuntamente com o regulador vegetal realizou-se o anelamento de ramos isoladamente ou conjuntamente com o desponte de cachos, maiores larguras foram observadas com a dose 60ppm (Figuras 74 e 75).

Porém, na Tabela 51, nota-se que quando as doses 35; 47,5 e 60ppm de ácido giberélico foram aplicadas, não houve diferença estatística entre as técnicas.

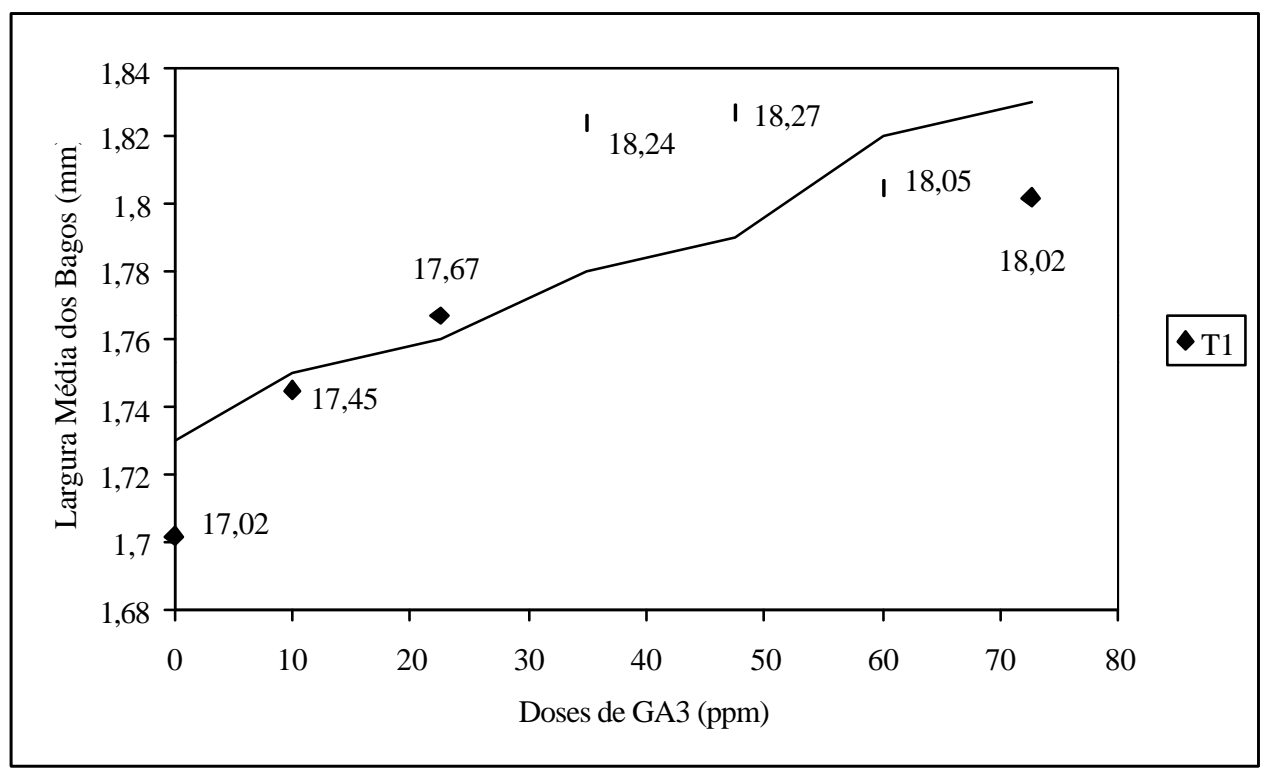

Figura 73 - Efeito da aplicação de diferentes doses de ácido giberélico, realizada isoladamente (sem a prática do anelamento de ramos e/ou desponte de cachos), sobre a largura média dos bagos da cultivar Vênus, durante o ciclo vegetativo de 2000. 


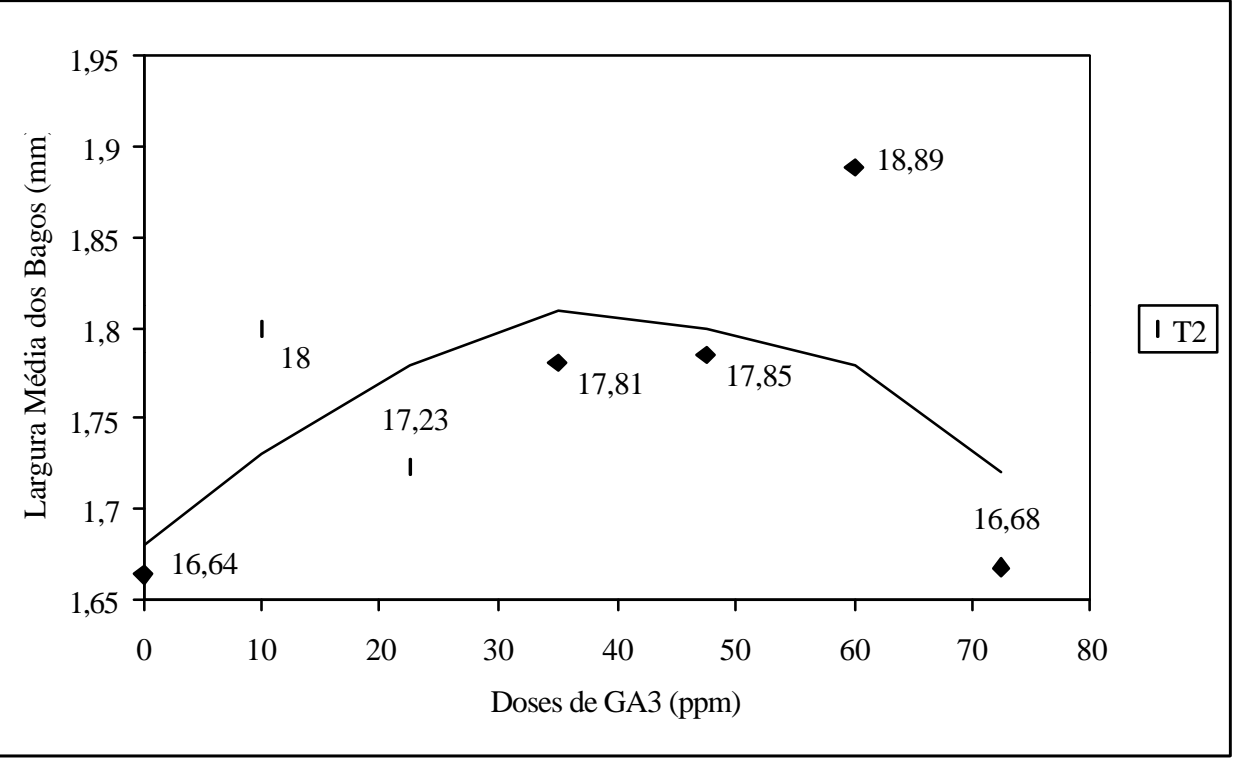

Figura 74 - Efeito da aplicação de diferentes doses de ácido giberélico, realizada juntamente com a prática do anelamento de ramos, sobre a largura média dos bagos da cultivar Vênus, durante o ciclo vegetativo de 2000.

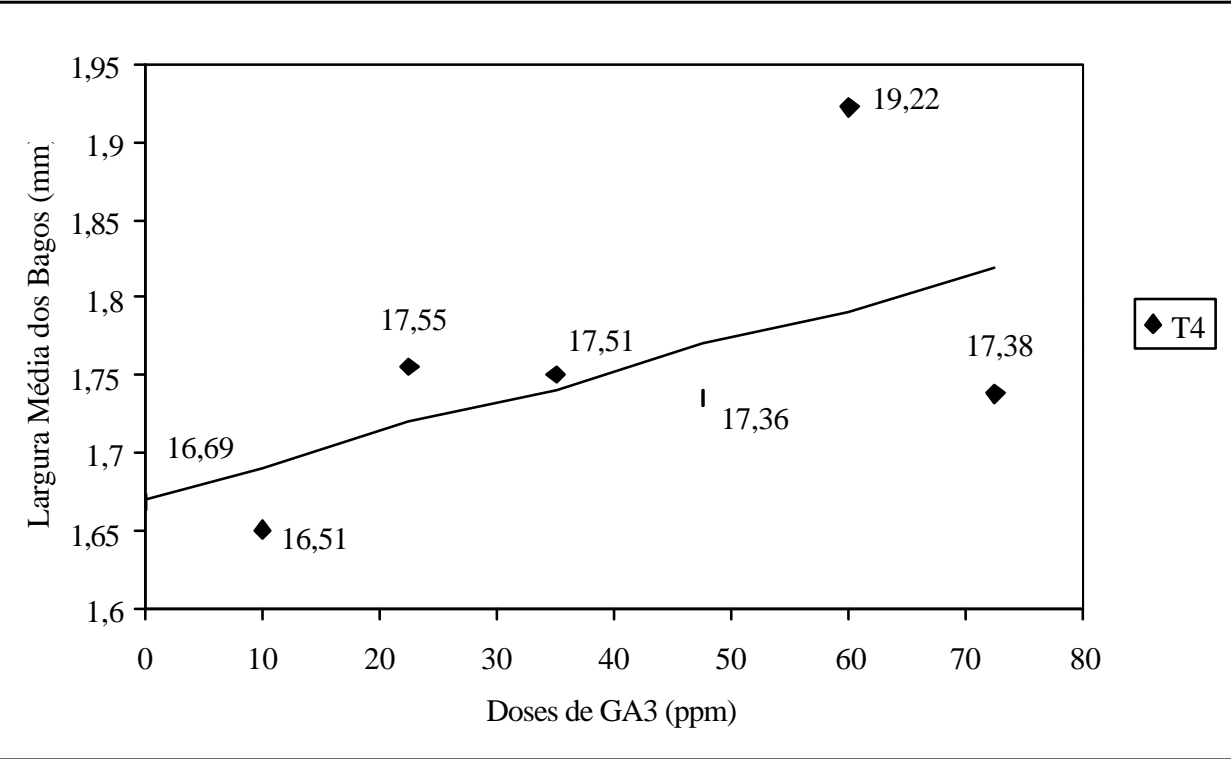

Figura 75 - Efeito da aplicação de diferentes doses de ácido giberélico, realizada juntamente com a prática do anelamento de ramos e do desponte de cachos, sobre a largura média dos bagos da cultivar Vênus, durante o ciclo vegetativo de 2000 . 
Tabela 52. Aplicação de regressão polinomial para a massa média dos bagos da cultivar Vênus durante o ciclo vegetativo de 2000.

\begin{tabular}{cc}
\hline & Regressão Polinomial para as doses de Ácido Giberélico \\
\hline Efeito Linear & $27,040^{* *(1)}$ \\
Efeito Quadrático & $9,787^{* *}$ \\
\hline
\end{tabular}

${ }^{(1)}$ Significativo ao nível de $1 \%$ de probabilidade.

A massa média de bagos foi afetada apenas por doses do regulador vegetal em estudo, não sendo significativa a interação entre os fatores (Tabela 75). Analisando a Figura 76 nota-se maiores massas de bagos com as doses 47,5ppm (4,115g) e 60ppm $(4,123 \mathrm{~g})$ de ácido giberélico.

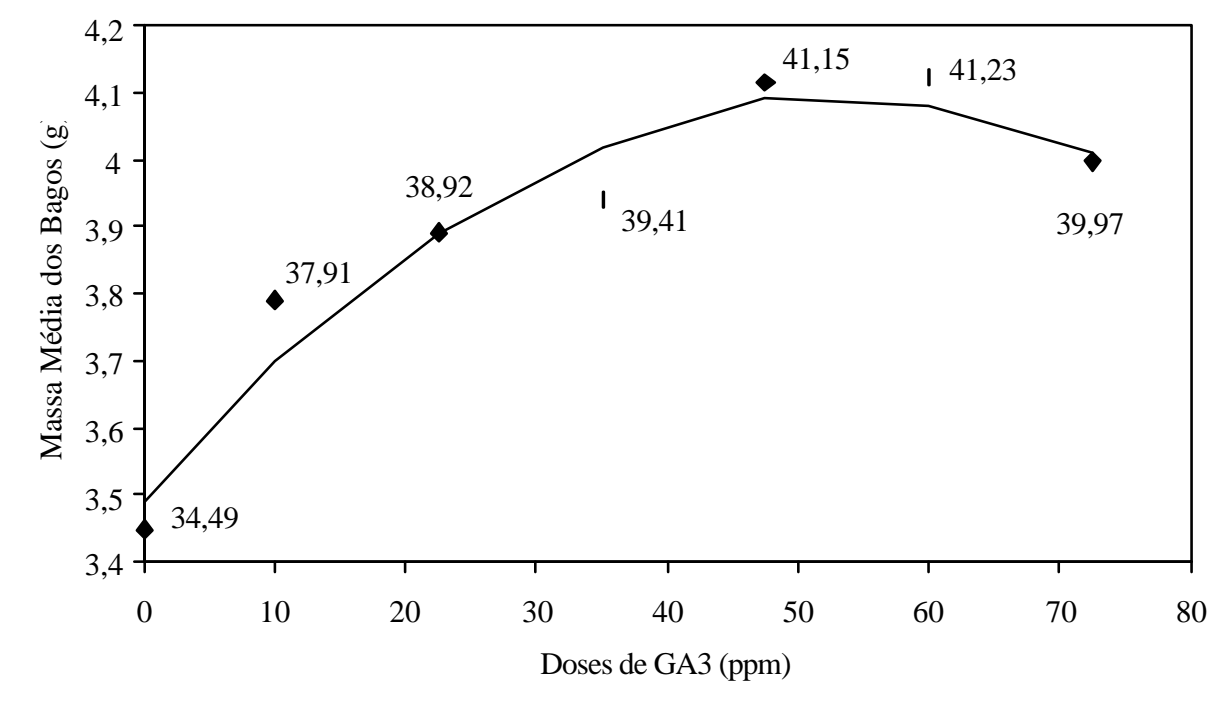

Figura 76 - Efeito de diferentes doses de ácido giberélico, sobre a massa média dos bagos da cultivar Vênus, durante o ciclo vegetativo de 2000. 
Tabela 53. Aplicação do teste de Tukey e de regressão polinomial para a acidez titulável da cultivar Vênus durante o ciclo vegetativo de 2000.

\begin{tabular}{|c|c|c|c|c|}
\hline Causas da variação & \multicolumn{4}{|c|}{ Teste de Tukey para as médias das técnicas dentro das doses de GA3 } \\
\hline Doses de GA3 & Técnica 1 & Técnica 2 & Técnica 3 & Técnica 4 \\
\hline Oppm & 0,732 b B & $0,868 \mathrm{ab} \mathrm{AB}$ & $0,786 \mathrm{ab} \mathrm{AB}$ & 0,924 a $\mathrm{A}$ \\
\hline 10,0ppm & 0,778 a $A^{(1)}$ & 0,735 a $\mathrm{A}$ & 0,769 a $\mathrm{A}$ & 0,742 a $\mathrm{A}$ \\
\hline 22,5ppm & 0,753 a $\mathrm{A}$ & 0,852 a $\mathrm{A}$ & 0,747 a $\mathrm{A}$ & 0,795 a $\mathrm{A}$ \\
\hline 35,0ppm & 0,811 a $\mathrm{A}$ & 0,775 a $\mathrm{A}$ & 0,784 a $\mathrm{A}$ & 0,895 a $\mathrm{A}$ \\
\hline 47,5ppm & 0,762 a $A$ & 0,832 a $\mathrm{A}$ & 0,787 a $\mathrm{A}$ & 0,844 a $\mathrm{A}$ \\
\hline 60,0ppm & 0,759 a $\mathrm{A}$ & 0,851 a $\mathrm{A}$ & 0,762 a $\mathrm{A}$ & 0,757 a $\mathrm{A}$ \\
\hline 72,5ppm & $0,735 \mathrm{~b} \mathrm{~B}$ & 0,909 a $\mathrm{A}$ & 0,693 b B & $0,821 \mathrm{ab} \mathrm{AB}$ \\
\hline
\end{tabular}

Regressão Polinomial para as doses de Ácido Giberélico dentro dos

$\begin{array}{lllll} & \text { Técnica 1 } & \text { Técnica 2 } & \text { Técnica 3 } & \text { Técnica 4 } \\ \text { Efeito Linear } & 0,016 \mathrm{~ns}^{(2)} & 2,921 \mathrm{~ns} & 1,540 \mathrm{~ns} & 1,092 \mathrm{~ns} \\ \text { Efeito Quadrático } & 1,558 \mathrm{~ns} & 3,730 \mathrm{~ns} & 1,022 \mathrm{~ns} & 0,195 \mathrm{~ns}\end{array}$

${ }^{(1)}$ Médias dentro de uma linha seguidas de uma mesma letra minúscula ou maiúscula não diferem significativamente ao nível de $5 \%$ e $1 \%$ de probabilidade, respectivamente.

${ }^{(2)}$ Não significativo ao nível de $5 \%$ de probabilidade.

Na Tabela 53, verifica-se que não houve efeito significativo de doses de ácido giberélico sobre a acidez total titulável do mosto. Também, observa-se que quando o ácido giberélico não foi aplicado, maior acidez foi obtida quando as duas técnicas foram realizadas conjuntamente, diferindo estatisticamente do tratamento-controle.

O teor de sólidos solúveis foi afetado pelas diferentes doses de ácido giberélico, somente quando realizou-se conjuntamente a prática do anelamento de ramos, sendo que doses crescentes geraram decréscimo nesta característica (Figura 77).

Este resultado foi concordante com àquele obtido no primeiro ensaio com a cultivar Vênus, sugerindo que o ácido giberélico pode promover um atraso na maturação dos frutos quando aplicado quinze dias após o florescimento pleno. 
Tabela 54. Aplicação do teste de Tukey e de regressão polinomial para o teor de sólidos solúveis da cultivar Vênus durante o ciclo vegetativo de 2000.

\begin{tabular}{|c|c|c|c|c|}
\hline Causas da variação & \multicolumn{4}{|c|}{ Teste de Tukey para as médias das técnicas dentro das doses de GA3 } \\
\hline Doses de GA3 & Técnica 1 & Técnica 2 & Técnica 3 & Técnica 4 \\
\hline Oppm & $16,990 \mathrm{a} \mathrm{A}^{(1)}$ & 16,125 a $\mathrm{A}$ & 17,050 a $\mathrm{A}$ & 15,440 a $\mathrm{A}$ \\
\hline 10,0ppm & 16,280 a $\mathrm{A}$ & 16,970 a $\mathrm{A}$ & 15,150 a $\mathrm{A}$ & 17,210 a $\mathrm{A}$ \\
\hline 22,5ppm & 14,940 a $\mathrm{A}$ & 15,790 a $\mathrm{A}$ & 15,730 a $\mathrm{A}$ & 17,400 a $\mathrm{A}$ \\
\hline 35,0ppm & 16,930 a $\mathrm{A}$ & $15,030 \mathrm{ab} \mathrm{AB}$ & 16,240 a $\mathrm{AB}$ & $12,550 \mathrm{~b} \mathrm{~B}$ \\
\hline 47,5ppm & 15,470 a $\mathrm{A}$ & 15,400 a A & 14,750 a $\mathrm{A}$ & 13,150 a $\mathrm{A}$ \\
\hline $60,0 \mathrm{ppm}$ & $16,530 \mathrm{~b} \mathrm{~B}$ & $13,670 \mathrm{~b} \mathrm{~B}$ & $17,000 \mathrm{ab} A B$ & 17,950 a $\mathrm{A}$ \\
\hline \multirow[t]{3}{*}{ 72,5ppm } & $16,100 \mathrm{ab} A$ & $13,440 \mathrm{~b} \mathrm{~A}$ & 17,030 a $\mathrm{A}$ & $15,995 \mathrm{ab} A$ \\
\hline & \multicolumn{4}{|c|}{$\begin{array}{l}\text { Regressão Polinomial para as doses de Ácido Giberélico dentro dos } \\
\text { níveis do fator técnicas }\end{array}$} \\
\hline & Técnica 1 & Técnica 2 & Técnica 3 & Técnica 4 \\
\hline Efeito Lin & $0,089 \mathrm{~ns}^{(2)}$ & $9,027 * *(3)$ & $0,330 \mathrm{~ns}$ & $0,054 \mathrm{~ns}$ \\
\hline Efeito Quadrático & $0,505 \mathrm{~ns}$ & $0,313 \mathrm{~ns}$ & $2,346 \mathrm{~ns}$ & $3,746 \mathrm{~ns}$ \\
\hline
\end{tabular}

${ }^{(1)}$ Médias dentro de uma linha seguidas de uma mesma letra minúscula ou maiúscula não diferem significativamente ao nível de $5 \%$ e $1 \%$ de probabilidade, respectivamente.

(2) Não significativo ao nível de $5 \%$ de probabilidade.

${ }^{(3)}$ Significativo ao nível de $1 \%$ de probabilidade.

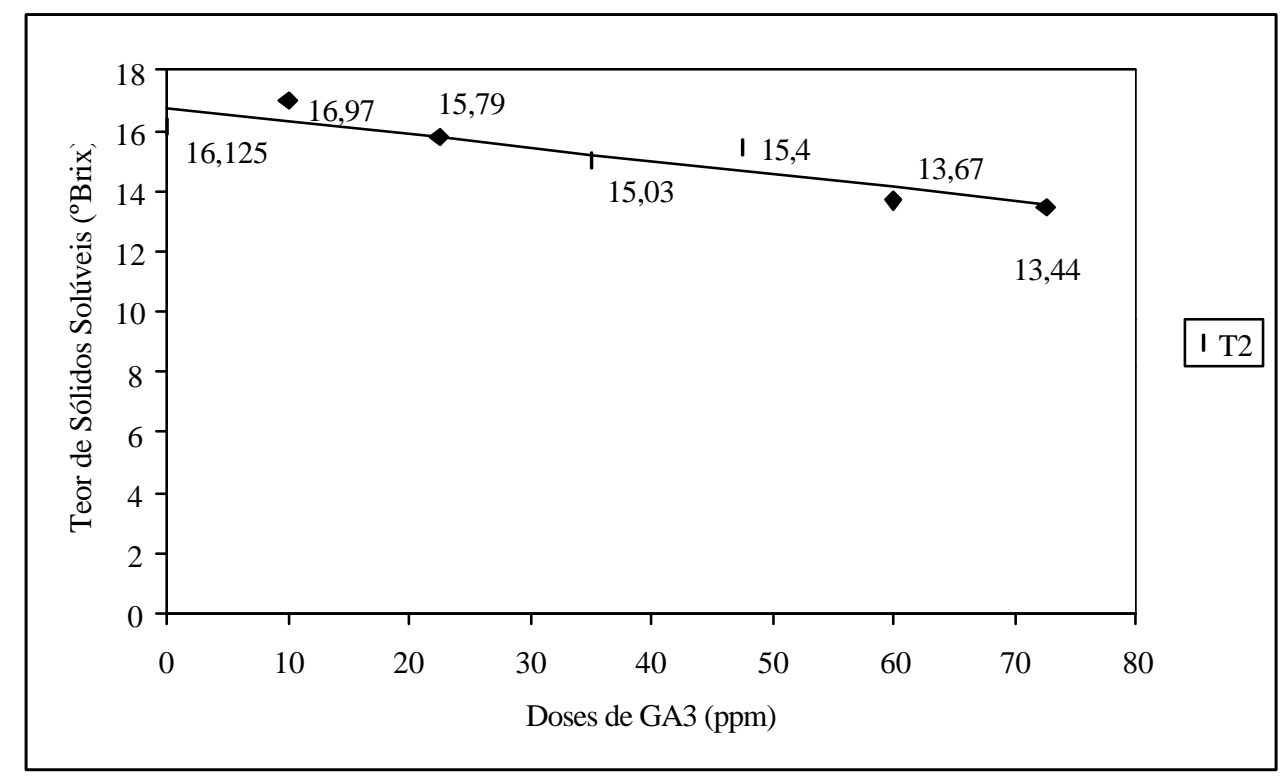

Figura 77 - Efeito da aplicação de diferentes doses de ácido giberélico, realizada juntamente com a prática do anelamento de ramos, sobre o teor de sólidos solúveis da cultivar Vênus, durante o ciclo vegetativo de 2000. 


\section{CONCLUSÕES}

\section{1 'Niagara Rosada' - Primeiro ciclo vegetativo de 1999}

A. Não houve influência do anelamento sobre a massa, a largura e o comprimento médio dos cachos e a massa média dos engaços, sendo estas características afetadas apenas por doses de ácido giberélico.

B. Detectou-se que a dose de $35 \mathrm{ppm}$ de ácido giberélico sendo aplicada isoladamente originou os maiores incrementos sobre o comprimento e a massa média de cachos, e sobre a massa média dos engaços. Já, o maior incremento sobre a largura média dos cachos foi observado com a dose de 47,5ppm.

C. O comprimento e a largura média dos engaços não foram afetados pelos diferentes tratamentos.

D. O diâmetro médio dos pedicelos foi aumentado quando as diferentes doses de ácido giberélico, particularmente 47,5ppm, foram aplicadas conjuntamente com o anelamento de ramos.

E. Tanto o tamanho, quanto a massa média dos bagos foram influenciados pela aplicação, isolada ou em conjunto com o anelamento de ramos, de ácido giberélico. Quando aplicado isoladamente, maiores incrementos foram obtidos com a aplicação de 35ppm. Já, os maiores incrementos nestas características foram proporcionados pela aplicação de 47,5ppm do regulador vegetal conjuntamente com o anelamento de ramos.

F. Detectou-se que o ácido giberélico aplicado isoladamente tendeu a diminuir o teor de sólidos solúveis totais do mosto. Porém, quando conjuntamente realizoutse o anelamento de ramos, houve uma tendência de aumento nesta característica, observando-se maior incremento com a dose de 35ppm. 
G. O aumento da dose de ácido giberélico proporcionou o aumento da acidez total titulável do mosto. Porém, quando aplicado conjuntamente com o anelamento, aumentando-se a dose, diminuiu-se a acidez total titulável do mosto.

\section{2 'Niagara Rosada' - Segundo ciclo vegetativo de 1999}

A. Maiores incrementos no tamanho e na massa média de bagos, e no diâmetro médio dos pedicelos foram obtidos com a aplicação de 60ppm de ácido giberélico conjuntamente com o anelamento de ramos.

B. Maiores incrementos na massa e largura médias de cachos e no número médio de bagos por cacho puderam ser obtidos com a dose de 35ppm aplicada conjuntamente com o anelamento de ramos.

C. Quanto aplicado isoladamente, maiores doses de ácido giberélico originaram uma diminuição no teor de sólidos solúveis totais do mosto e um aumento da acidez total titulável. Quando conjuntamente realizou-se o anelamento de ramos, pode-se até notar um aumento no teor de sólidos solúveis totais com doses intermediárias $(22,5$; 35 e $47,5 \mathrm{ppm})$.

\section{3 'Vênus' - Ciclo vegetativo de 1999}

A. O desponte de cachos sendo realizado isoladamente ou conjuntamente com o anelamento gerou um encurtamento nos cachos e engaços.

B. O anelamento isoladamente ou juntamente com o desponte de cachos proporcionou maior massa dos cachos.

C. O número médio de bagos por cacho sofreu uma diminuição com o aumento da dose de ácido giberélico aplicado isoladamente.

D. Quanto maior a dose de ácido giberélico, maior foi o comprimento, a largura e a massa dos bagos.

O anelamento realizado isoladamente ou conjuntamente com o desponte também proporcionou o aumento nestas mesmas características. 
E. O teor de sólidos solúveis totais do mosto foi maior quando não se aplicou o ácido giberélico. Ainda, o anelamento realizado conjuntamente com o desponte de cachos proporcionou o maior incremento no teor de sólidos solúveis totais do mosto.

\section{4 'Vênus' - Ciclo vegetativo de 2000}

A. O desponte de cachos sendo realizado isoladamente ou em conjunto com o anelamento de ramos proporcionou menores comprimentos médios de cachos e engaços.

B. Quanto maior a dose de ácido giberélico, aplicada isoladamente, maiores foram os comprimentos médios e as larguras médias dos cachos e engaços.

C. A dose de 35ppm de ácido giberélico, aplicada conjuntamente com o anelamento de ramos ou com o anelamento e o desponte de cachos, proporcionou as maiores massas de cachos e engaços e o maior número médio de bagos por cacho.

D. Maiores bagos foram obtidos com a aplicação de 60ppm de ácido giberélico realizada conjuntamente com o anelamento de ramos isoladamente ou em conjunto com o desponte de cachos. A maior massa de bagos foi obtida com a aplicação isolada de 47,5ppm de ácido giberélico.

E. Obteve-se menores teores de sólidos solúveis totais com doses maiores do regulador vegetal aplicadas conjuntamente com a técnica de incisão anelar. 


\section{REFERÊNCIAS BIBLIOGRÁFICAS}

ALTAF, Q.; WAZIR, M.; HAMID, K.; KHALID, M. Effect of gibberellic acid on 'Flame Seedless' table grapes in Islamabad. Sarhad Journal of Agriculture, v.5, n.5, p.453-455, 1989.

ANTONACCI, D. Risposta produttiva delle uve apirene da tavola alle tecniche di forzatura. Vignevini, v.19, n.12, p.66-73, 1992.

ANTONACCI, D. Comportamento produttivo di nove cultivar di uve da tavola coltivate in ambiente protetto. Risultati di un decennio di ricerca. Vignevini, n.1/2, p. 53-62, 1993.

ANTONACCI, D.; COLETTA, A. Risposta dei vitigni di uva da tavola "Regina" e "Regina dei Vigneti" alla somministrazione di gibberelline. Rivista di Viticoltura e di Enologia, v.49, n.3, p.57-64, 1996.

CARREÑO, J.; FARAJ, S.; MARTINEZ, A. Effects of girdling and covering mesh on ripening, colour and fruit characteristics of 'Italia' grapes. Journal of Horticultural Science \& Biotechnology, v.7,n.1, p.103-106, 1998.

CASTRO, P.R.C. Ação do CEPA e do ácido giberélico na frutificação da videira "Niagara Rosada". Anais da Escola Superior de Agricultura "Luiz de Queiroz”, v.32, p.99-113, 1975. 
CLARK, J. R.; IRVIN, K. M.; FERNANDEZ, G. E. Effect of gibberellic acid on seed traces of 'Venus' and 'Saturn' grapes. Journal of Small Fruit and Viticulture, v.2, n.1, p.11-19, 1993.

COLAPIETRA, M.; TARRICONE, L.; AMICO, G. Risposta alla decorticazione anulare e all'acido gibberellico. Informatore Agrario, Supplemento, v.52, n.50, p.17-25, 1996.

EL HODAIRI, M.H.; IBRAHIM, S.B. Effects of gibberellic acid on Sultanine Seedless grape variety grown in the Libyan Sahara. Acta Horticulturae, v.409, p. 93-97, 1995.

GÓMEZ MORALES, M.A. Effecto del anillado e influencia del ácido giberélico sobre el raleo y crecimiento de bayas en uva de mesa (Vitis vinfera L.) cultivar Crimson Seedless en el Vale de Aconcagua. Quillota, 1999. (Taller de Licenciatura) - Facultad de Agronomia, Universidad Catolica de Valparaiso.

GONZALO, R.; OSMAN, G.; NELSON, P. Adelanto de maduracion y mejoramento de color de la uva cv. Moscatel Rosada. Investigación y Progreso Agropecuario La Platina, n.25, p.8-13, 1984.

HARRELL, D.C.; WILLIAMS, L.E. The influence of girdling and gibberellic acid application at fruitset on Ruby Seedless and Thompson Seedless grapes. American Journal of Enology and Viticulture, v.38, n.2, p.83-88, 1987.

KALIL, G.P.C.; TERRA, M.M.; KALIL FILHO, A.N.; MACEDO, J.L.V. de; PIRES, E.J.P. Anelamento e ácido giberélico na frutificação da uva 'Maria' sem sementes. Scientia Agricola, v.56, n.2, p.317-328, abr./jun. 1999. 
KASIMATIS, A.N.; SWANSON, F.H.; VILAS JR., E.P. Effects on bloom applied gibberellic acid on soluble solids and berry weight of Thompson Seedless grapes and on raisin grapes. American Journal of Enology and Viticulture, v.29, p.263-266, 1978.

LEE, D.K.; HWANG, H.S.; SUH, H.S.; PARK, K.S.; YAE, B.W. Effects of GA on the induction of seedlessness and cluster growth of 77 grape cultivars. RDA Journal of Horticultural Science, v.39, n.1, p.127-133, 1997.

MUÑHOZ, H.; PEZOA, J. Cultivar Superior: Accion del acido giberelico y anillado. Investigación y Progreso Agropecuario La Platina, n.79, p.18-20, 1993.

PEREIRA, F.M.; OLIVEIRA, J.C. de. Ação da giberelina sobre cachos de cv. de videira Patrícia. Científica, v.4, p.175-180, 1976.

PEREIRA, F.M. ;OLIVEIRA, J.C. de. Efeitos da giberelina aplicada antes e depois do florescimento sobre cachos de uva 'Itália'. Científica, v.5, n.2, p.175-179, 1977.

PEREIRA, F.M.; SIMÃO, S.; MARTINS, F.P.; IGUE, T. Efeitos da giberelina sobre cachos da cultivar de videira Niagara Rosada. Científica, v.7, n.1, p.53-58, 1979.

PERUZZO, E.L. Anelamento dos ramos em variedades de uva de mesa. Agropecuária Catarinense, v.7, n.4, p.21-23, 1994.

PIRES, E.J.P. Emprego de reguladores de crescimento em viticultura tropical. Informe Agropecuário, v.19, n.194, p. 40-43, 1998. 
POMMER, C.V.; TERRA, M.M.; PIRES, E.J.P.; PICININ, A.H.; PASSOS, I.R.da S. Efeito do anelamento na maturação de uvas com sementes. Revista Brasileira de Fruticulura, v.13, n.3, p.147-150, 1991.

POMMER, C.V.; TERRA, M.M.; PIRES, E.J.P.; PICININ, A.H.; PASSOS, I.R.da S. Influência do anelamento e do ácido giberélico em características do cultivar apireno de uvas Maria. Bragantia, v.54, n.1, p.151-159, 1995.

POMMER, C.V.; PASSOS, I.R.da S.; TERRA, M.M.; PIRES, E.J.P. Variedades de videira para o Estado de São Paulo. Campinas: Instituto Agronômico, 1997. 59p. (IAC. Boletim Técnico, 166).

RETAMALES, J.; BANGERTH, F.; COOPER, T. Efecto de dosis de acido giberelico sobre produccion, crecimiento y desgrane de uva Sultanina. Aconex, v.42, p. 16-21, oct./dic., 1993.

RETAMALES, J.; BANGERTH, F.; COOPER, T.; CALLEJAS, R. Effects of CPPU and $\mathrm{GA}_{3}$ on fruit quality of Sultanina table grape. Acta Horticulturae, n.394, p.149-157, 1995.

ROPER, T.R.; WILLIAMS, L.E. Net $\mathrm{CO}_{2}$ assimilation and carbohydrate partitioning of grapevine leaves in response to trunk girdling and gibberellic acid application. Plant Physiology, v.89, n.4, p.1136-1140, 1989.

SAROOSHI, R.A. Some effects of girdling, gibberellic acid sprays, bunch thinning and timing on the Sultana. Australian Journal of Experimental Agriculture and Animal Husbandry, v.17, n.87, p.700-704, 1977.

SOUSA, J.S.I. Uvas para o Brasil. 2.ed. Piracicaba: FEALQ, 1996. 791p.. 
TAIZ, L.; ZEIGER, E. Plant Physiology. 2.ed. Sunderland: Sinauer Associates, 1998. 792p.

TERRA, M.M.; PIRES, E.J.P.; NOGUEIRA, N.A.M. Tecnologia para a produção de uva Itália na região noroeste do Estado de São Paulo. 2.ed. Campinas: Coordenadoria de Assistência Técnica Integral, 1998. 81p. (CATI. Documento Técnico, 97).

TOMÁS COOPER, C.; ClAUdiA BOTTI, G.; JULIO RETAMALES, A. RODRIGO CALLEJAS, R. Desgrane en uva Sultanina: aspectos histologicos y mecanicos. Aconex, v.41, p.5-10, jul./sep., 1993.

WINKLER, A.J.; COOK, J.A.; KLIEWER, W.M.; LIDER, L.A. General viticulture. Berkeley: University of California Press, 1974. 710p.

ZABADAL, T.J. Response of 'Himrod' grapevines to cane girdling. HortScience, v.27, n.9, p. 975-976, 1992. 